Universidade de São Paulo

Faculdade de Arquitetura e Urbanismo

GUSTAVO GRAZZIANO

CÓDICE:

o tempo em suspensão

São Paulo | 2016 

CÓDICE:

o tempo em suspensão 

Gustavo Grazziano

\section{CÓDICE: \\ o tempo em suspensão}

Dissertação apresentada à Fa-

culdade de Arquitetura e Urbanismo da Universidade de São Paulo para obtenção do título de mestre em Ciências, Programa de Arquitetura e Urbanismo - Design e Arquitetura.

Orientador:

dr. Feres Lourenço Khoury

São Paulo, 2016 
Autorizo a reprodução e divulgação total ou parcial deste trabalho, por qualquer meio convencional ou eletrônico, para fins de estudo e pesquisa, desde que citada a fonte.

gustavo.grazziano@gmail.com

Grazziano, Gustavo

G785 Códice: o tempo em suspensão / Gustavo Grazziano.

- São Paulo, 2016.

228 p. : il.

Dissertação (Mestrado - Área de Concentração: Design e Arquitetura) - FAUUSP.

Orientador: Feres Lourenço Khoury

1.Códices 2.Livros de artistas 3.Obras raras 4.Zen budismo 5.Desenho 6.Pintura de técnica mista 7.Livro de horas 8.Wabi-sabi I.Título CDU 655.1 
GRAZZIANO, Gustavo

CÓDICE: O TEMPO EM SUSPENSÃO

Aprovado em:

\section{Banca Examinadora}

Professor(a) Doutor(a):

Instituição:

Julgamento:

Assinatura:

Professor(a) Doutor(a):

Instituição:

Julgamento:

Assinatura:

Professor(a) Doutor(a):

Instituição:

Julgamento:

Assinatura: 

DEDICATÓRIA

à Lúcia Pinto pela escuta diária,

ao Raphael Grazziano pelo incansável apoio,

ao Francisco de Paulo Grazziano e à Eliane da Silva Grazziano,

ao Feres Lourenço Khoury por generosamente ter me recebido e acompanhado. 



\section{AGRADECIMENTOS}

ao Diego Melém Gozze e ao Gabriel Portella por ajudarem com os registros fotográficos,

ao Ricardo Kenji Kussano por ajudar com a tradução,

à Andressa Tiossi Rodrigues pela leitura e revisão do texto,

ao Bruno Uehara pela ótima conversa sobre pintura e zen -budismo,

à USP e à FAU,

Aos professores Agnaldo Farias, Angela Maria Rocha, Clice de Toledo, Fernanda Fernandes, Klara Anna Maria Kaiser Mori, Luís Antônio Jorge e Vicente Gil Filho,

à Luise Weiss por indiretamente ter me ajudado agora e durante a graduação,

à Residência São João e à EAV Parque Lage, aos colegas Antonia Moura, Antonio Sobral, Bek Andersen, Damiana Bregalda Jaenisch, Daniel Jablonski, Erika Malzoni, Guilherme Gutman, Hyngrid Bermann, Júlia Ayerbe, Leo Ayres, Marina Marchesan, Michelle Sommer, Priscila Rampin, Silvino Mendonça, Simone Moraes M. de Barros, Yasmin e aos funcionários da Fazenda São João,

à todos com quem convivi durante os três anos de pesquisa. 



\section{RESUMO}

Refletindo sobre uma sensação de leveza e dilatação da passagem temporal, a pesquisa elabora a expressão "tempo suspenso" e analisa de que maneira essa singular percepção pode ser transmutada em códices. Para sua compreensão, dialoga sobretudo com duas produçóes artísticas: Em busca do tempo perdido (1908-1922), de Marcel Proust, e A última tempestade (1991), de Peter Greenaway. A primeira foi escolhida por discutir uma sensação como estopim para a elaboração de uma poética. A segunda, por colocar o códice artesanal como receptáculo de um assunto. $\mathrm{O}$ campo formado pelas duas referências aglutina a temática levantada e representa princípios geradores e norteadores no desenvolvimento de uma sintaxe visual composta de referências históricas e formais da estrutura do códice. Ademais, para a compreensão da dilatação do tempo foram analisadas obras clássicas japonesas onde se encontram características próprias dos termos wabi-sabi e ma. Elas são a representação estética de um método no qual a práxis poética é um momento decisivo na estruturação do objeto final. A partir dos diálogos estabelecidos, foram realizados sete livros de artista, chamados de códices, cada um apresentado separadamente em capítulos formados por registros fotográficos e textos contextualizadores dos assuntos elaborados.

PALAVRAS-CHAVE: Códices; Livros de artistas; Obras raras; Zen budismo; Desenho; Pintura de técnica mista; Livro de horas; Wabi-Sabi. 



\section{ABSTRACT}

Reflecting upon a soft and expanding sense of the passage of time, this research elaborates the term "suspended time", analyzing how this singular perception is possibly transformed into codex art. It dialogues mainly with two artistic works for further comprehension: Marcel Proust's In Search of Lost Time (1908-1922) and Peter Greenway's Prospero's Book (1991). The first one has been chosen for debating a sensation as the trigger for the elaboration of poetics. The second one for setting the handicraft codex as receptacle of a subject. The field formed by both works ties together the presented topic and represents the generative and guiding principles of a visual syntax made up of formal and historical references from the codex structure. Furthermore, in order to comprehend the expansion of time, classical Japanese works in which specific characteristics of the terms wabi-sabi and ma appear, have been analyzed. They are the aesthetic representation of a method in which the poetic praxis has a major role in the final object construction. Seven artists' books named codex have been created out of the established discussion, each one is presented separately in chapters formed by photographic records and guiding texts about the formulated topics.

KEYWORDS: Codex; Artist's books; Rare works; Zen buddhism; Drawing; Mixed media painting; Book of hours; Wabi-Sabi. 

SUMÁRIO

\section{Resumo \\ 15 Abstract}

23 Introdução

37 Códice n. 1

61 Códice n.2

81 Códice n. 3

105 Códice n.4

137 Códice n.5

163 Códice n.6

187 Códice n.7

211 Comentários finais

217 Lista de imagens

223 Ref. bibliográfica 

... levei aos lábios uma colherada de chá onde deixara amolecer um pedaço de madalena. Mas no mesmo instante em que aquele gole, de envolta com as migalhas do bolo, tocou meu paladar, estremeci, atento ao que se passava de extraordinário em mim. Invadira-me um prazer delicioso, isolado, sem noção de sua causa. Esse prazer logo me tornara indiferente às vicissitudes da vida, inofensivos seus desastres, ilusória sua brevidade, tal como o faz o amor, enchendome de uma preciosa essência: ou, antes, essa essência não estava em mim, era eu mesmo. Cessava de me sentir mediocre, contingente, mortal. De onde me teria vindo aquela poderosa alegria? Senti que estava ligada ao gosto do chá e do bolo, mas que o ultrapassava infinitamente e não devia ser da mesma natureza. De onde vinha? Que significava? Onde apreendê-la? Bebo um segundo gole que me traz um pouco menos que o segundo. É tempo de parar, parece que está diminuindo a virtude da bebida. É claro que a verdade que procuro não está nela, mas em mim. A bebida a despertou, mas não a conhece, e só o que pode fazer é repetir indefinidamente, cada vez com menos força, esse mesmo testemunho que não sei interpretar e que quero tornar a solicitar-lhe daqui a um instante e encontrar intato à minha disposição, para um esclarecimento decisivo. Deponho a taça e volto-me para meu espirito. É a ele que compete achar a verdade. Mas como? Grave incerteza, todas as vezes em que o espirito se sente ultrapassado por si mesmo, quando ele, o explorador, é ao mesmo tempo o país obscuro a explorar e onde todo o seu equipamento de nada lhe servirá. Explorar? Não apenas explorar: criar. Está diante de qualquer coisa que ainda não existe e a que só ele pode dar realidade e fazer entrar em sua luz.

Proust, Marcel. Em Busca do Tempo Perdido : No caminho de Swann, $71-72$. 





\section{INTRODUÇÃO}

O conjunto de trabalhos aqui apresentado é composto por sete livros de artista. Nele, estabeleço uma trama que cobre poeticamente a superfície de referências pessoais, tendo por intento, predominantemente, o diálogo poético com duas produçōes artísticas: Em busca do tempo perdido, de Marcel Proust, ${ }^{1}$ e $A$ última tempestade, de Peter Greenaway. ${ }^{2}$ A expressão poética, materializada nos livros produzidos, dialoga com as duas referências em um processo desvelador de novas possibilidades líricas e apresenta percursos não supostos em seu início.

O campo formado pelas duas obras citadas aglutina interesses e representa princípios geradores e norteadores de investigações nas quais teoria, prática e poética resultaram nos sete livros que denomino códices, expostos nos capítulos a seguir. Uma questão comum norteia a totalidade desta produção sendo ela a passagem inicial do romance de Proust, na qual o protagonista, ao dar um gole no chá e comer um pedaço de Madalena, é invadido por sensaçôes desconhecidas, iniciando o desemaranhar de suas memórias apresentadas ao longo de toda

\footnotetext{
${ }^{1}$ Marcel Proust, Em busca do tempo perdido, 7 vols. (São Paulo: Globo, 2006).

${ }^{2}$ Peter Greenaway, A última tempestade, NTSC, colorido, Longa-metragem (Lume filmes, 1991).
} 
a obra. Do mesmo modo, a pesquisa parte de uma sensaçấo e tem o objetivo de torná-la palpável. A ela chamo de "tempo suspenso", em um exercício de sintetizar em um termo a abrangência representada pela poética pessoal.

Esse tempo caracteriza-se pela sensação de ruptura em seu encadeamento natural - passado, presente e futuro - para sua expansão eterna e unificação do todo em um único instante do agora. Se posso descrevê-lo, baseado em minhas prévias experiências, sem diminuir ou limitar o significado de tal percepção (para durante a pesquisa ampliar sua compreensão tendo o mínimo de conceitos preestabelecidos), diria ser um momento de marasmo e reticência temporal em meio ao cotidiano. Invade-me ao rememorar o passado, em especial a infância; ao ver um filme; ao escutar uma melodia tocada em determinado ritmo; ao vivenciar algo banal durante um dia qualquer. Ela não exige estar imerso em um momento, lugar ou em uma estação do ano específica para acontecer. Seja em um dia nublado em qual mal se veem os prédios ao final da rua; em uma tarde ensolarada, sob a brisa fresca do outono e envolto pelo som do gramado; seja dentro de uma biblioteca, com o movimento repetitivo do ventilador, dos cliques de mouse e do passar distante de um avião. Esse tempo está em todos os lugares, só cabe a mim encontrá-lo. Poderia também intencionalmente revê-lo? Proust adverte ser possível em relação a sua percepção.

É assim com nosso passado. Trabalho perdido procurar evocá-lo, todos os esforços de nossa inteligência permanecem inúteis. Está ele oculto, fora de seu domínio e de seu alcance, em algum objeto material (na sensação que nos daria esse objeto material) que nós nem suspeitamos. Esse objeto, só do acaso depende que o encontremos antes de morrer, ou que não o encontremos nunca. ${ }^{3}$

Ainda assim, poderia meu tempo ser de outra natureza e passível de evo-

\footnotetext{
${ }^{3}$ Proust, Em Busca do Tempo Perdido : No caminho de Swann, 1:60; ibidem, 1:118.
} 


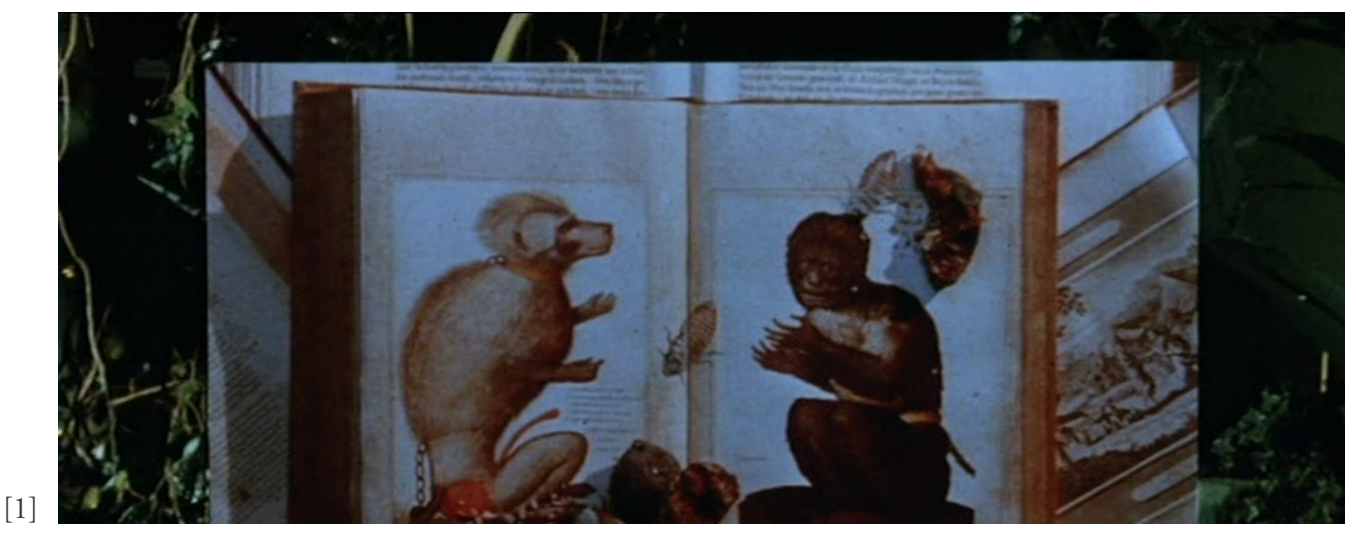

[2]

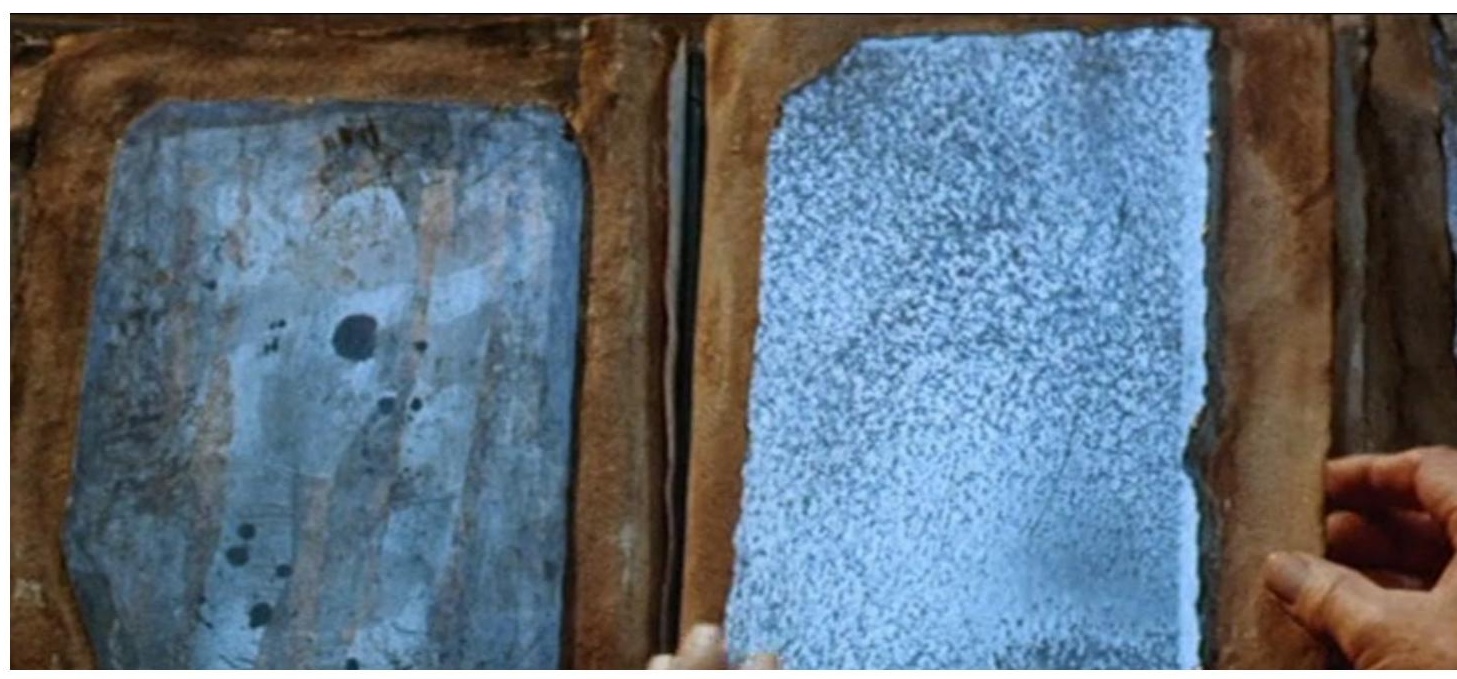

[3]

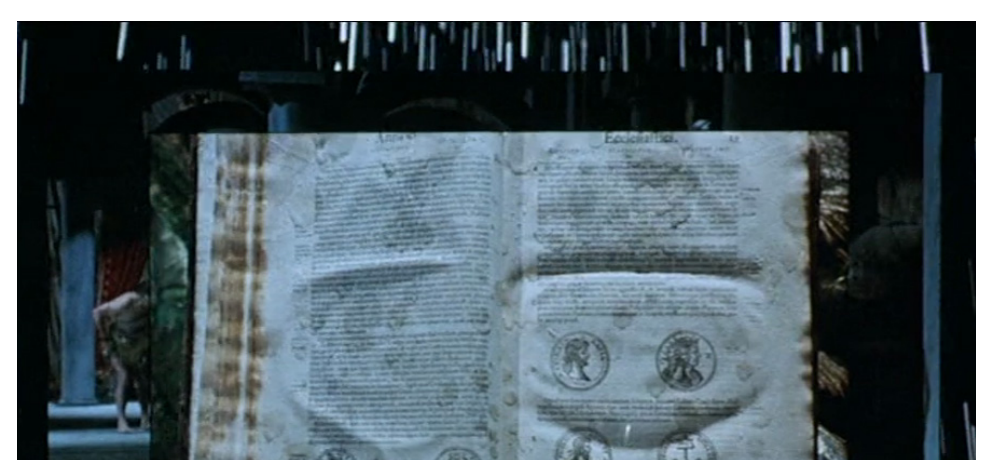



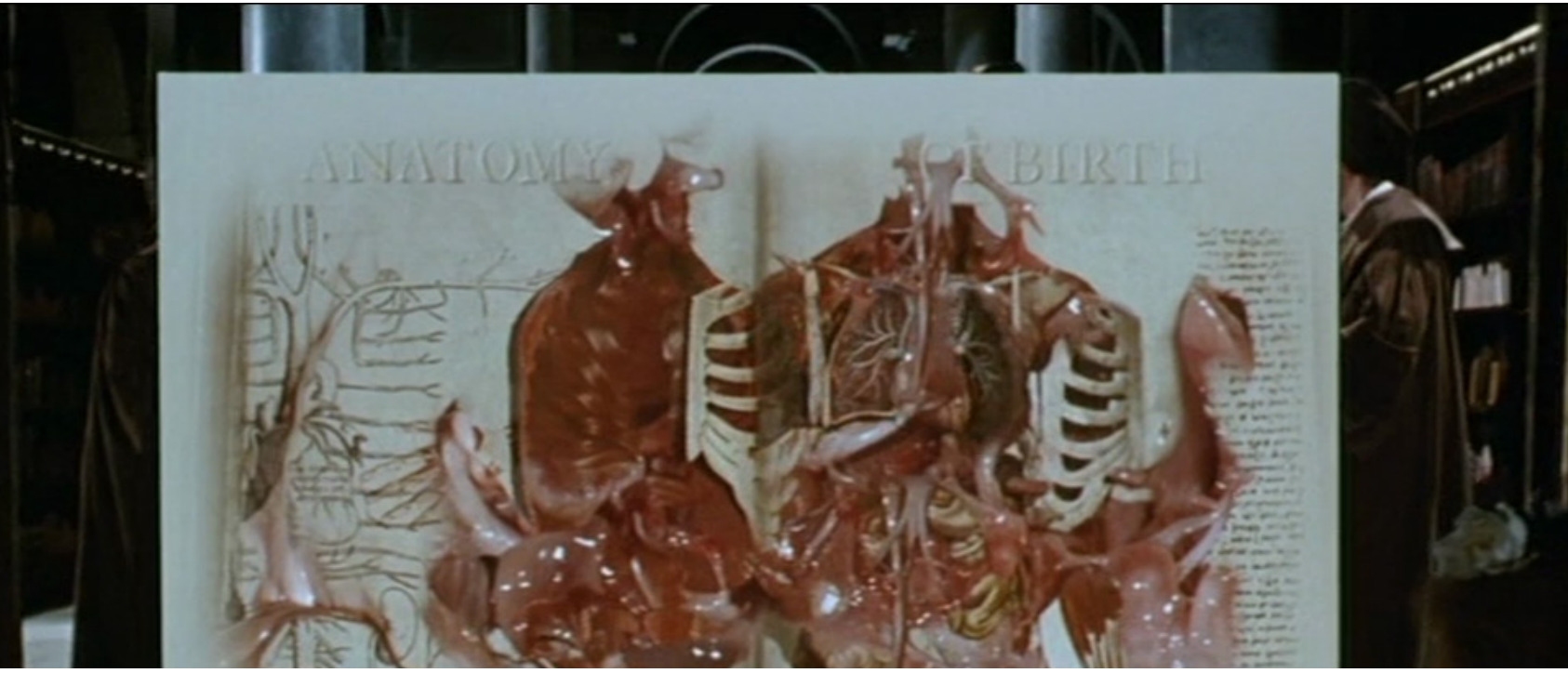

[4]
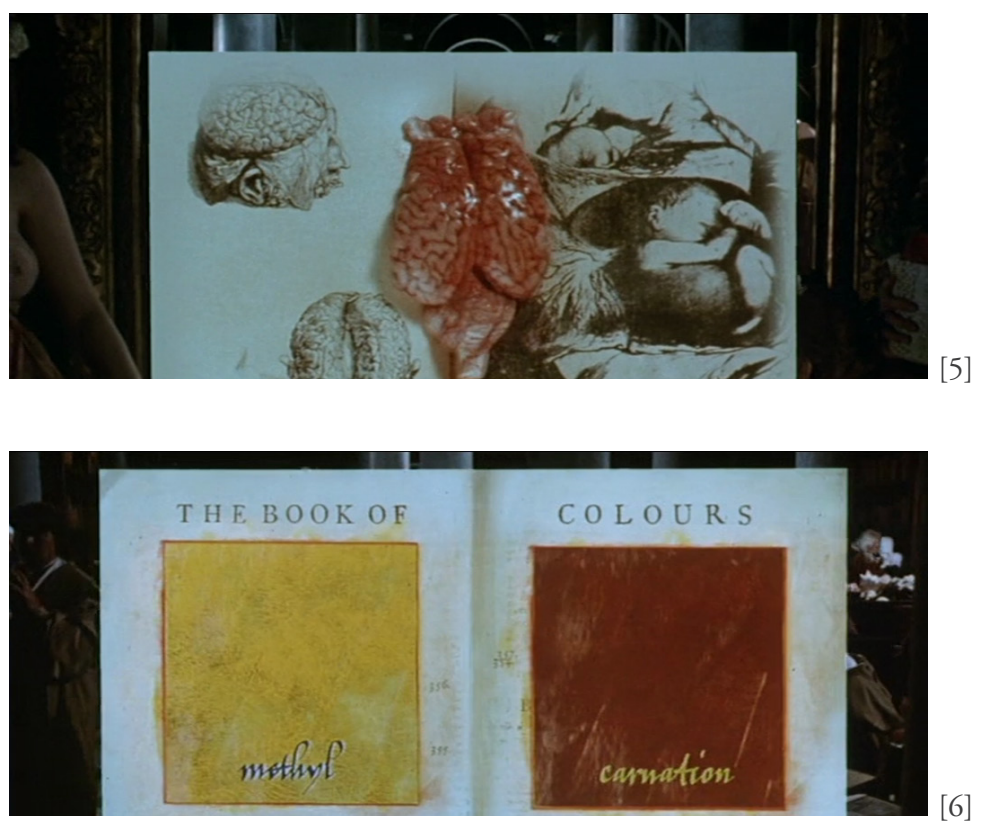
cação? Ou apenas posso me dar conta dele quando já imerso em seu fluir? Afinal, como disse antes, sua presença não se dá apenas na rememoração. Ele se manifesta de múltiplas formas: em memória, no viver e na apreciação de diferentes produçôes artísticas.

Se, por um lado, o motivo da pesquisa surge em consonância com o desejo do protagonista de Em Busca do Tempo Perdido ${ }^{4}$ por encontrar a origem da sensação que se manifesta, o meio no qual a pesquisa se dá tem origem no filme A última tempestade. ${ }^{5}$ Baseado em A Tempestade, ${ }^{6}$ a obra acompanha Prospero, um nobre que tem seu ducado usurpado pelo próprio irmáo e é exilado em uma ilha, acompanhado de sua filha. Junto dele, o irmáo envia a biblioteca cujo narrador possui estima maior até mesmo em relação a sua antiga posição social.

\section{Knowing I lov'd my books, he furnish'd me from mine own library with volumes that I prize above my dukedom.}

Durante o filme são apresentados, dentro de cena ou sobrepostos à imagem principal, vinte e quatro livros pertencentes à tal biblioteca imaginária. Sendo, em sua maior parte, descritos por um narrador externo, eles representam uma fração dos livros em posse de Prospero. Neles, se nota a grande variedade de recursos empregados na organização de um vasto conhecimento. Cada livro

\footnotetext{
${ }^{4}$ Proust, Em busca do tempo perdido.

${ }^{5}$ Greenaway, A última tempestade.

${ }^{6}$ William Shakespeare, A tempestade, trad. Rafael Raffaelli (Santa Catarina: Editora UFSC, 2014).

7 "Sabendo o quanto amava meus livros, ele me abasteceu a partir de minha própria biblioteca com volumes que prezo acima de meu ducado." Greenaway, A última tempestade, nossa tradução.
} 
tem um tema: água, espelhos (existentes ou fictícios), cores, geometria, anatomia, a lista de todas as pessoas que já morreram ou morrerão, um bestiário de criaturas que já existiram, existem ou existirão. A lista é longa e nela há desde livros com conteúdos plausíveis, se não já existentes, até informaçóes impossíveis, como quando se prevê o futuro em códices envolvendo conhecimentos a beirar o infinito. Para transformar táo variado repertório de informaçóes em livros, seus imaginários escritores teriam recorrido a vastos recursos artesanais: capa em ouro com diversos espelhos (alguns mágicos) em seu interior, um livro de tamanho descomunal, outro de tamanho reduzido, uma grande variedade de papéis, amostras de plantas, fotografias, desenhos, gravuras, textos manuscritos ou impressos. As técnicas para a manufatura desses objetos são extensas e simbolizam o esforço da busca por traduzir conhecimentos individuais para a linguagem desse objeto. Por meio dos livros é possível - utilizando palavras, imagens, colagens, múltiplos materiais e formatos - romper as barreiras físicas e temporais impostas pelo discurso oral na transmissão de conhecimento. ${ }^{8}$

A biblioteca de Prospero é repleta de livros, em especial um tipo específico desse objeto: o códice. Tendo surgido após diversas outras configuraçóes de livros - como tábuas de cera, madeira, pedra, rolos de pergaminho e sanfona - o códice se disseminou no ocidente através da Bíblia. ${ }^{9}$ Dentre suas peculiaridades em relação às outras estruturas de livros - em especial comparadas ao rolo, seu antecessor utilizado em Roma - está o fato de ser compacto, não precisar enrolar e desenrolar para ser lido, a possibilidade de manipulá-lo com apenas uma mão, a facilidade na organização em estantes ou pilhas e a praticidade na identificação de um exemplar específico apenas lendo sua lombada.

\footnotetext{
${ }^{8}$ Para uma discussão mais aprofundada em relação a capacidade do livro em romper os limites físico-temporais existentes na tradição do discurso oral George Steiner, "O silêncio dos livros", trad. André Telles, Serrote, no 17 (julho de 2014): 77-107.

${ }^{9}$ Mais informaçôes em relação à origem do códice em Michel Melot, Livro, (Cotia, SP: Ateliê Editorial, 2012). Em especial das páginas 26 a 28.
} 
Seu tempo, caracterizado pela dobra e pela alternância de páginas, é distinto do rolo, no qual há sempre o contínuo fluir do texto em seu desenrolar. No códice, de outro modo, a alternância de páginas, mediante a dobra, permite ao leitor a consciência de todo o livro ao mesmo tempo sendo possível voltar sua atenção a uma única página. Reside na dobra uma das maiores peculiaridades desse objeto, ela introduz um novo tempo para o livro, um tempo fragmentado e definido pelo espaço da página. Ademais, a existência da dobra central nas folhas direcionou ao uso do pergaminho para a confecção das páginas: um material mais resistente e flexível em comparação ao papiro, permitindo, por sua vez, a produção de traços regulares para a formataçáo do tamanho das linhas. Por fim, a existência de duas capas em suas extremidades encerra o conteúdo dentro de seus limites físicos, tornando-o finito dentro de sua unidade. ${ }^{10}$

\section{A forma do livro é uma 'forma simbólica', no sentido atribuido por Panofsky à 'perspectiva como forma simbólica'. Ou seja, uma forma que expressa, por si própria, de modo implícito, todo um jogo de valores e de representaçôes do mundo. ${ }^{11}$}

No contexto desta pesquisa a biblioteca de Prospero representa um diálogo do códice com o livro de artista contemporâneo. Essa classificação de livro remonta ao começo do século XX se sustentando definitivamente como expressão artística após a metade deste século. Sua origem, assim como sua definição, não é nítida, sendo tênue a diferença em relação a outras linguagens de livros: como o fotolivro, livro de pintor e livro-objeto. Independentemente de uma definição absoluta e duradoura, o livro de artista pode ser classificado como a produção de um trabalho artístico na forma do livro sem que o conteúdo represente

\footnotetext{
${ }^{10}$ Discussão prolongada quanto as singularidades do códice em comparação às demais formas de livro em Ibidem, cap. 1 e 2.

${ }^{11}$ Ibidem, 63.
} 
a mera reprodução de algo já existente. Este pode ser impresso em inúmeros tamanhos, papéis ou processos gráficos; seja único ou com larga tiragem; tendo todas as funçôes sido desempenhadas por um único artista ou por terceiros; no formato de códice ou não. ${ }^{12}$ As linguagens são múltiplas, sendo os volumes aqui expostos formados exclusivamente por códices únicos. Neles, há pinturas que adquirem um distinto significado quando pertencentes ao contexto do códice, uma vez que cada pintura individual está relacionada com as demais páginas duplas do objeto, e assim, inseridas em sua singular temporalidade.

A pesquisa é estruturada em forma de rede e se beneficia das qualidades dessa organização ao permitir o crescimento indefinido da investigaçáo seguindo assuntos levantados pelo próprio projeto. ${ }^{13} \mathrm{Nela}$, toda a malha se estende pelo tema tempo suspenso, no qual cada capítulo da dissertação representa um nó na rede que explora o assunto a partir múltiplas abordagens. Essa organização do projeto propiciou o encontro de novas interpretaçôes, a retomada de assuntos pouco desenvolvidos em outros capítulos e a recombinação de diferentes ideias levantadas anteriormente.

A sequência de capítulos - Códices de n.1 a n.7, cada um apresentado individualmente - caracteriza o projeto. Em alguns casos os capítulos podem ser lidos individualmente. Ainda assim, eles se conectam globalmente no desdobramento de assuntos levantados durante a investigaçáo. Dentro deles ainda há uma subdivisão: cada uma das sete partes é composta por textos que apresentam e contextualizam o livro produzido na referida etapa e, ao final,

\footnotetext{
${ }^{12}$ Para a conceituação da categoria livro de artista Paulo Silveira, A página violada: Da ternura à injúria na construção do livro de artista, 2o ed (Porto Alegre: Editora da UFRGS, 2008), 25-71, e Johanna Drucker, The century of artists' books (Nova York, Estados Unidos da América: Granary Books, 2012), 2. Quanto a consolidação desse meio como expressão poética, consultar em especial o capítulo 4 do livro de Drucker.

${ }^{13}$ Mais sobre a estruturação do conhecimento em forma de rede em Anne Cauquelin, Arte contemporânea: Uma introdução (São Paulo: Martins Editora, 2005), 59-60.
} 
há o seu registro fotográfico. Textos e objetos são unidades indissociáveis e representam etapas na busca por ampliar a diversidade de poéticas suscitadas pelo tempo suspenso. Portanto, o conjunto do projeto representa um olhar amplo do assunto proposto inicialmente. 

... tudo aquilo fazia da igreja, para mim, alguma coisa de inteiramente diverso do resto da cidade: um edificio que ocupava, por assim dizer, um espaço de quatro dimensóes - a quarta era a do Tempo - e impelia através dos séculos sua nave que, de abóbada em abóbada, de capela em capela, parecia vencer e transpor não simplesmente alguns metros, mas épocas sucessivas de onde saía triunfante ...

Marcel Proust. Em Busca do Tempo Perdido : No caminho de Swann, 1:90. 





\section{CÓDICE N.1}

Esta minha estatuazinha de gesso, quando nova

- O gesso muito branco, as minhas linhas muito puras -

Mal sugeria imagem da vida

(Embora a figura chorasse).

Há muitos anos tenho-a comigo.

O tempo envelheceu-a, carcomeu-a, manchou-a de pátina amarelosuja.

Os meus olhos, de tanto a olharem,

Impregnaram-na de minha humanidade irônica de tísico.

Um dia mão estúpida

Inadvertidamente a derrubou e partiu.

Então ajoelhei com raiva, recolhi aqueles tristes fragmentos, recompus a figurinha

que chorava.

E o tempo sobre as feridas escureceu ainda mais o sujo mordente da pátina...

Hoje este gessozinho comercial

É tocante e vive, e me fez agora refletir

Que só é verdadeiramente vivo o que já sofreu. ${ }^{14}$

${ }^{14}$ Manuel Bandeira, "Gesso", in Estrela da vida inteira (Rio de Janeiro, 1990), 87-88. 
A poética do tempo suspenso já está presente nos principais projetos pessoais feitos desde o trabalho de conclusão da graduação, à época influenciado por filmes como Abril despedaçado, ${ }^{15}$ Asas do desejo, ${ }^{16}$ Café lumiére ${ }^{17}$ e A viagem do balão vermelho. ${ }^{18}$ Nos quatro filmes estão presentes ritmos narrativos semelhantes. Aproxima-os especialmente o fato de os diretores registrarem por longos períodos de tempo pequenos acontecimentos da vida cotidiana, como em Asas do Desejo, ${ }^{19}$ em que durante uma cena de aproximadamente seis minutos em uma biblioteca berlinense, anjos passeiam como em uma coreografia por entre os seres vivos, que não interagem nem mesmo veem as criaturas celestiais. No decurso do caminhar, a agitação de pensamentos é audível em contraste com a concentração em leituras e estudos das pessoas. Já em A viagem do balâo vermelho, ${ }^{20}$ em uma cena de três minutos, um pequeno garoto francês filma e conversa com sua babá, enquanto ela prepara a refeição. A longa duração das cenas, com tempos dilatados, registra vagarosos acontecimentos, existindo espaço para a contemplação e reflexão enquanto somos direcionados por entre uma cena e outra do filme.

Nesse período o termo "tempo suspenso" ainda não era utilizado para englobar a totalidade da poética pessoal. Por mais que a nova expressão adotada direcione a linguagem evolvida na práxis, ela não é o bastante para defini-la. Os primeiros problemas da pesquisa logo se tornam aparentes: como investigar

\footnotetext{
${ }^{15}$ Walter Salles, Abril despedaçado, NTSC, colorido, Longa-metragem (Imagem filmes, 2001).

${ }^{16}$ Win Wenders, Asas do desejo, Colorido e preto \& branco, Longa-metragem (Europa filmes, 1988).

${ }^{17}$ Hsiao-Hsien Hou, Café Lumiére, NTSC, colorido, 2004.

${ }^{18}$ Hsiao-Hsien Hou, A viagem do balão vermelho, NTSC, colorido, Longa-metragem (Casablanca, 2009).

${ }^{19}$ Wenders, Asas do desejo, 16:37-22:26.

${ }^{20} \mathrm{Hou}$, A viagem do balão vermelho, 24:07.
} 
uma percepção? De qual modo aprofundar a compreensão? Por fim, como dar forma ao explorar esteticamente esse tempo sem que, como Francis Bacon cita constantemente em relação a sua produção, ao final, o trabalho comunique o assunto perseguido diretamente em vez de recorrer a uma ilustração? ${ }^{21} \mathrm{O}$ processo de investigação estética, por meio da produção de livros, não tem por fim simplesmente representar ou descrever tal percepçáo, mas sim torná-la viva em um objeto que fala e é, ele próprio, a materialização do tempo suspenso.

No entanto, como Santo Agostinho já notou, mesmo o tempo sendo um elemento intrínseco à vida, logo escapa ao se tentar explicá-lo.

Que é, pois, o tempo? Quem poderá explicá-lo clara e brevemente? Quem o poderá apreender, mesmo só com o pensamento, para depois nos traduzir por palavras o seu conceito? E que assunto mais familiar e mais batido nas nossas conversas do que o tempo? Quando dele falamos, compreendemos o que dizemos. Compreendemos também o que nos dizem quando dele nos falam. O que é, por conseguinte, o tempo? Se ninguém me perguntar, eu sei; se o quiser explicar a quem me fizer a pergunta, já não sei. ${ }^{22}$

A percepção dele não é apenas física, mas também psicológica. Tudo e todos estão imersos na mesma passagem cronológica, porém percebida de modos

\footnotetext{
${ }^{21}$ Durante as entrevistas, feitas entre 1962 e 1986, em David Sylvester, Entrevistas com Francis Bacon (São Paulo: Cosac Naify, 2007), Francis Bacon levanta inúmeras vezes o desejo por produzir uma arte que não ilustre ou narre um assunto. Em especial, as páginas 18, 22, 56, 65 e 94 tratam sobre essa questấo. Em suas palavras "gostaria muitíssimo de fazer aquele coisa que Valéry disse: proporcionar emoçôes sem o tédio da comunicação." Ibidem, 64.

${ }^{22}$ Santo Agostinho, Confissóes, trad. J. Oliveira Santos e Ambrósio de Pina (São Paulo: Nova Cultural, 1996), 261.
} 
distintos por cada um. No caso, o tempo suspenso seria como um rio em uma área plana cujo fluir lento, chegando quase a não ser notado, lentamente carrega o que estiver suspenso em suas águas.

Como rumo inicial, o primeiro livro da pesquisa busca na história desse objeto a sintaxe visual para a compreensão da poética inicialmente estabelecida. De sua consolidaçáo na forma de Bíblia a sua disseminação após avanços no campo gráfico iniciados por Gutemberg, o códice passou por um longo e lento processo de amadurecimento tanto em sua estrutura quanto na escrita presente em suas páginas. Elementos como a definição de sentido de leitura da esquerda para direita e a introdução da pontuação, índice, folha de rosto, formato e proporção da mancha de texto, são hoje consolidados e pré-requisitos de todo livro, contudo levaram longos anos para serem desenvolvidos. ${ }^{23}$

Durante seu longo desenvolvimento, o livro passou por dificuldades no acesso aos materiais necessários para compô-lo, em especial com relaçáo ao pergaminho. O material extraído do couro de novilhos era de difícil acesso e produção quando comparado aos papéis existentes atualmente. O pergaminho é vantajoso para a confecção do códice por ser resistente e flexível, características importantes devido ao fato de as páginas serem vincadas ao meio e não quebrarem, como no caso do papiro. Porém, são suas próprias qualidades que possibilitaram a remoçáo de seu conteúdo por meio de raspagens e produtos químicos, em um processo conhecido como palimpsesto. ${ }^{24}$

\footnotetext{
${ }^{23}$ Em relação ao desenvolvimento da pontuação nos textos, ver Alberto Manguel, Uma história da leitura, trad. Pedro Maia Soares (São Paulo: Companhia das Letras, 1997), 64-66. Quanto ao surgimento dos diferentes elementos que compóem o conteúdo de um livro, consultar Melot, Livro, cap. 2-4. Para análise da influência da impressão na produção de livros Ana Paula Mathias de Paiva, A aventura do livro experimental (Belo Horizonte / São Paulo: Autêntica Editora / Edusp, 2010), 54-82.

${ }^{24}$ Descrição do processo de palimpsesto em Paiva, A aventura do livro experimental, 20-21.
} 
A supressão do conteúdo de livros pelo palimpsesto aconteceu pela dificuldade em se obter material para a escrita, mas não só. A censura de livros não foi rara ao longo da história, perpassada pela busca por livros proibidos ou mesmo pela destruição de bibliotecas inteiras. ${ }^{25} \mathrm{O}$ tema da apreensão e destruição de livros faz parte da história do códice e foi inclusive explorado na narrativa do romance Fahrenheit $451,{ }^{26}$ adaptado por Truffaut para o cinema. ${ }^{27}$

O livro produzido durante este capítulo do projeto utiliza como procedimento o palimpsesto. Raspagens e sobreposições são as linguagens utilizadas na articulaçáo de elementos por entre os espaços das páginas, estas podendo ser agrupadas em alguns conjuntos principais de acordo com suas características visuais: folhas com o conteúdo completamente censurado, restando somente os vestígios presentes nas margens da composição; formas gráficas semelhantes a ruínas; ou desenhos com o formato de blocos de texto.

O primeiro grupo é formado por páginas, em geral de cor cobre, nas quais há apenas a silhueta de um retângulo ocupando o espaço onde costuma estar presente a mancha de texto. Marcado por sucessivas camadas de desgaste, como em uma parede onde a açáo do tempo fez as múltiplas camadas de tinta desgastarem, mostrando uma vez mais cores que um dia habitaram completamente sua superfície.

Os outros dois grupos de composiçóes também adentram a estética do palimpsesto. No segundo grupo, a linguagem foi empregada na construçáo de ogivas e faixas cruzando a superfície da página dupla. Nelas o descascado do conteúdo cria a ilusão de profundidade, o oposto do terceiro grupo. Nesse último, o espaço da página lembra a mancha formada por linhas de texto,

\footnotetext{
${ }^{25}$ Alberto Manguel. Uma história da leitura. São Paulo: Companhia das Letras, 1997, p.311-323.

${ }^{26}$ Ray Bradbury. Fahrenheit 451. São Paulo: Biblioteca Azul, 2012.

${ }^{27}$ FAHRENHEIT 451. Direção: François Truffaut. Universal Pictures, 1966. 1 DVD (112 min), NTSC, colorido.
} 
ora gerando blocos concisos e ora apresentando linhas distribuídas na página, como em um poema de Mallarmé. ${ }^{28}$

Unindo os múltiplos conjuntos, uma capa roxa de tecido aveludado não aparenta fazer parte do agrupamento desde sua origem. Cromaticamente o conjunto é semelhante, contudo a capa não possui os desgastes do miolo, sugerindo a posterior reencadernação do conjunto. Somado a isso, na beirada de todas as páginas, na altura da costura, há a presença de um reforço estrutural para as folhas. Todo esse conjunto de características, aliado ao fato de ser um livro que pouco indica qual o sentido correto de leitura ou o significado de suas páginas, faz esse códice abrigar imprecisôes de interpretação próprias da imagem em comparação ao texto. $\mathrm{O}$ volume está impregnado de tempos distintos coabitando um mesmo espaço, seja o conteúdo das páginas com diversas camadas descascadas, seja no contraste entre a capa e o conteúdo; nesse objeto é visível o abstrato transcorrer do tempo.

\footnotetext{
${ }^{28} \mathrm{~A}$ forma do poema em questão é a distribuição das linhas exploradas por Stéphane Mallarmé, Um lance de dados, trad. Álvaro Faleiros (Cotia, SP: Ateliê Editorial, 2013), um dos precursores da linguagem do livros de artista segundo Drucker, The century of artists' books, 33-37.
} 


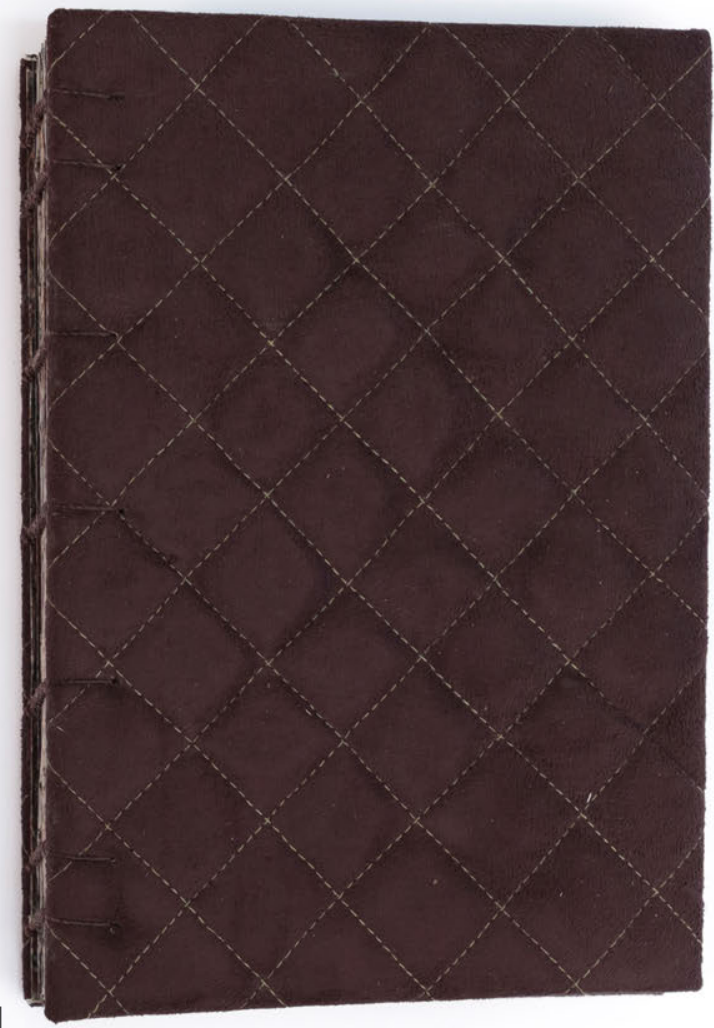

\section{CÓDICE N.1}

Técnica mista (papel, tecido, tinta acrílica, linha encerada, giz pastel oleoso, giz pastel seco, verniz).

$15,3 \times 21,6 \mathrm{~cm}$ (fechado)

$30,2 \times 21,6 \mathrm{~cm}$ (aberto)

2016

(Ver DVD anexo) 

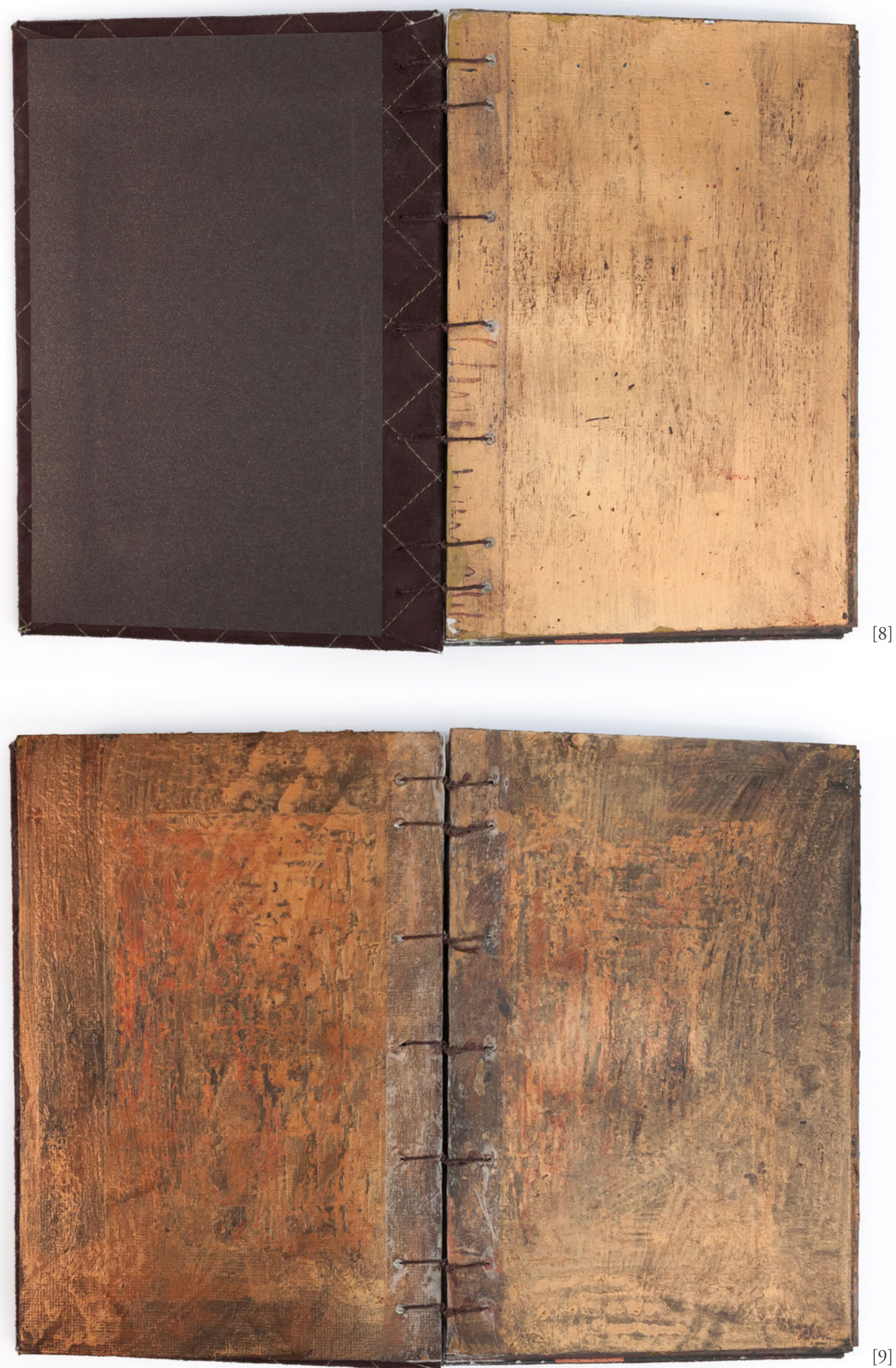


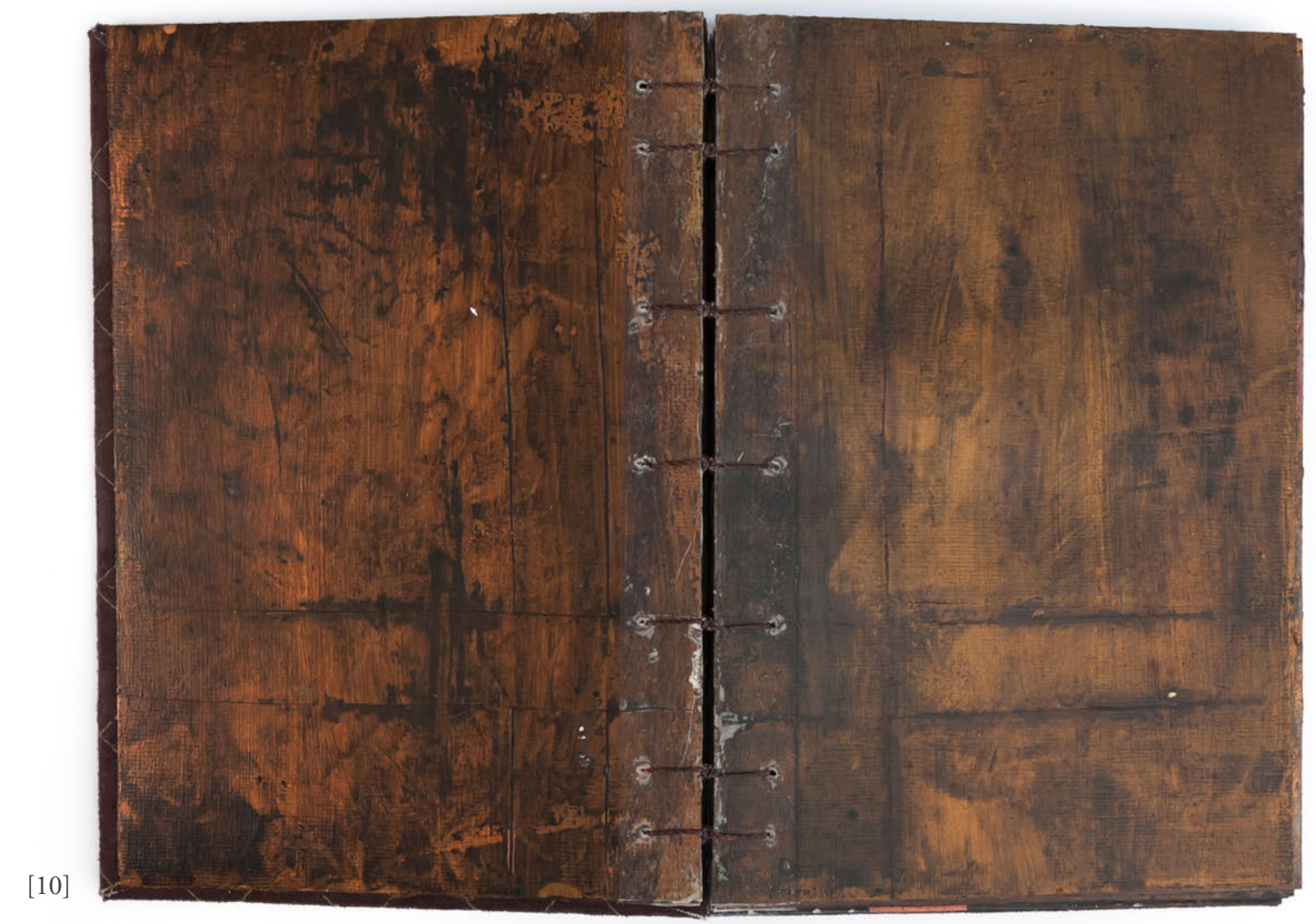

[11]

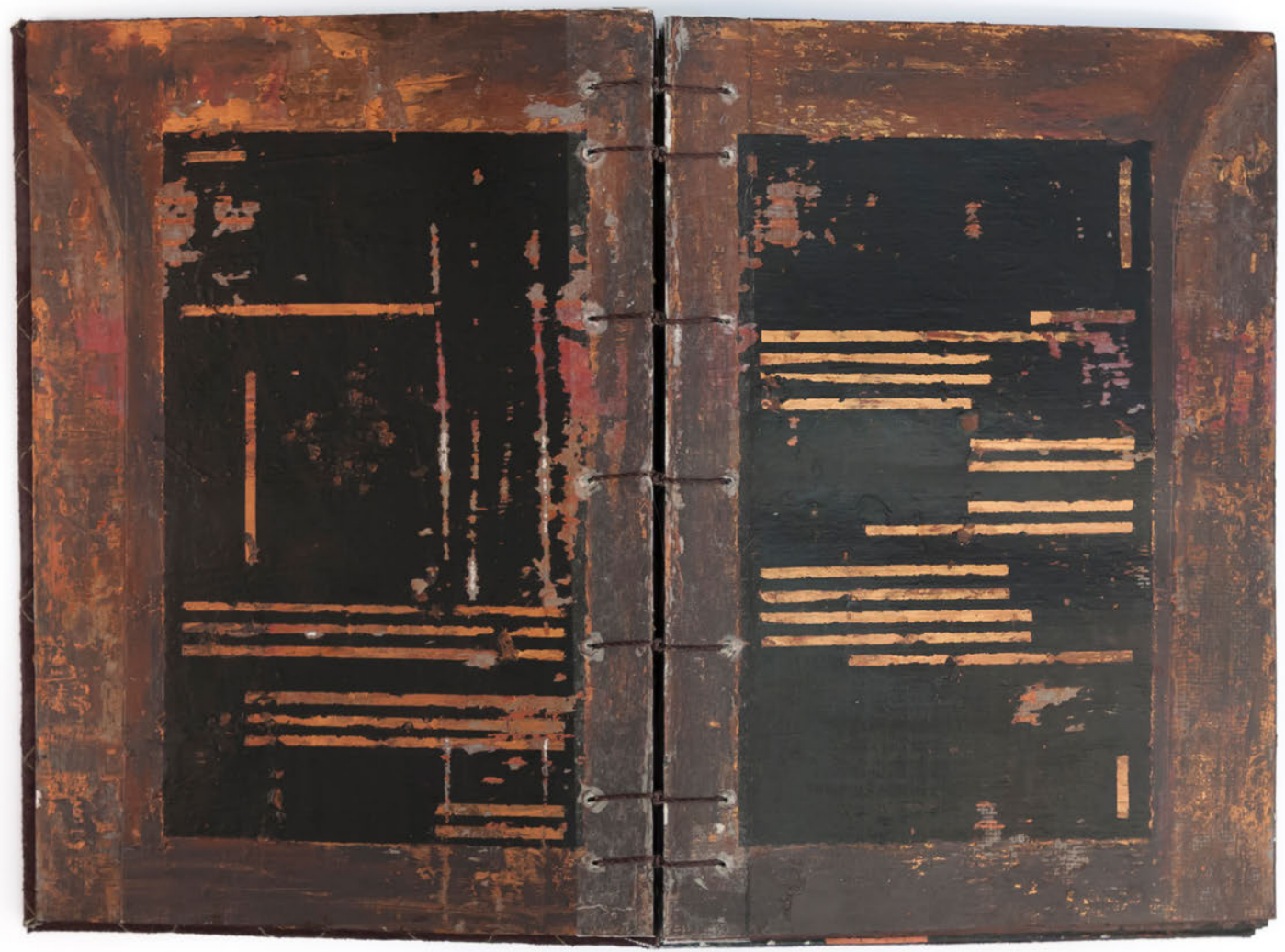




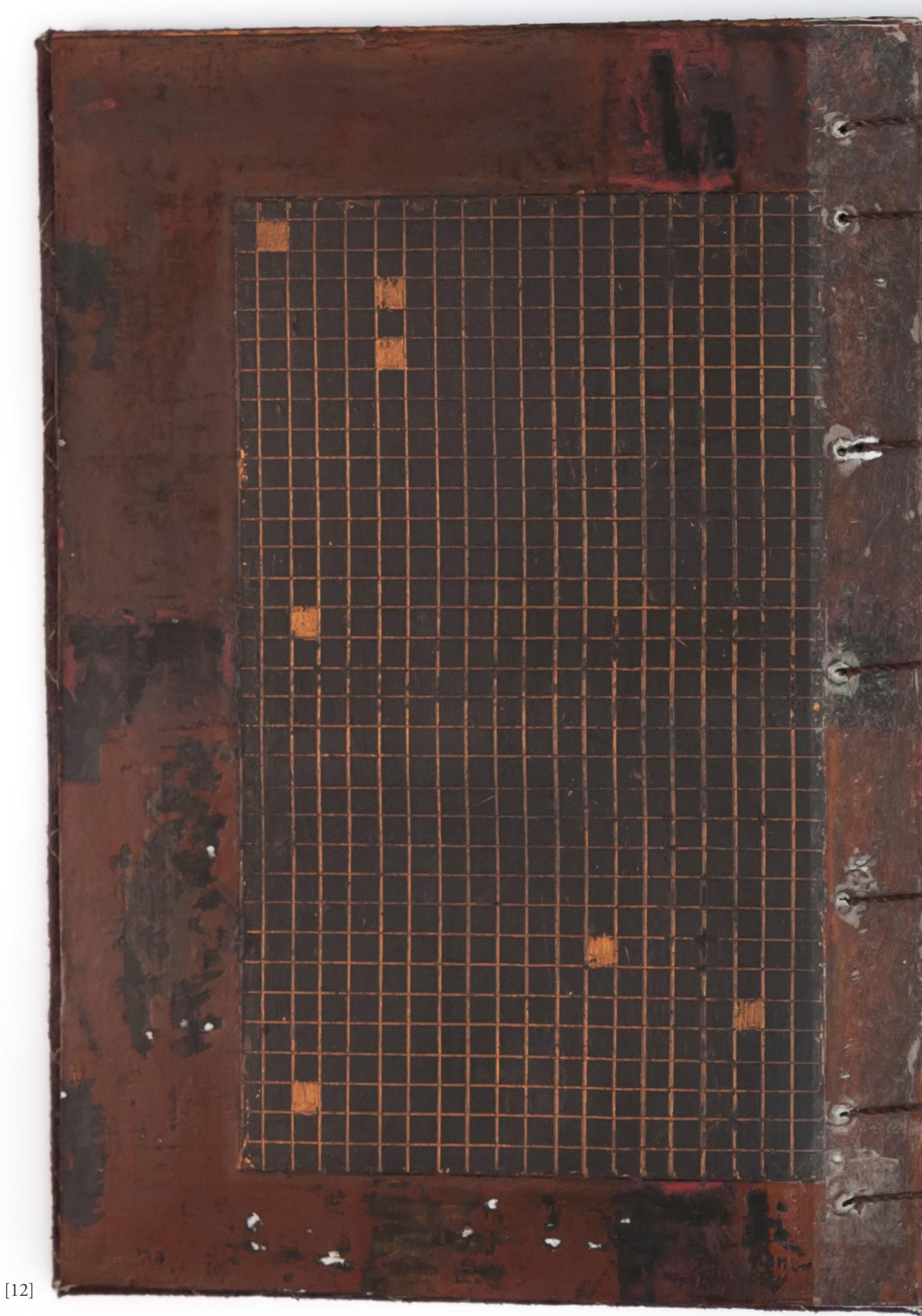




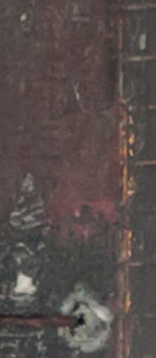

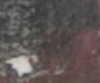

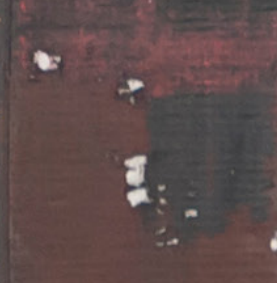

$-$

(1)

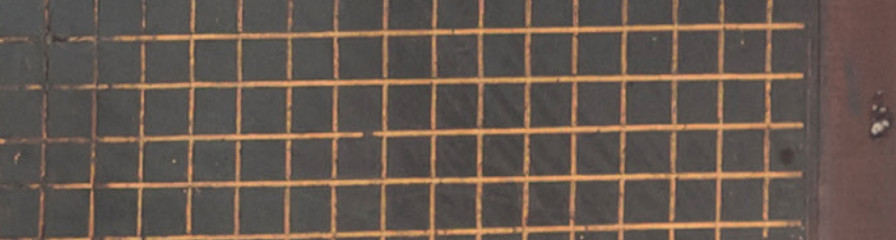

$\rightarrow$

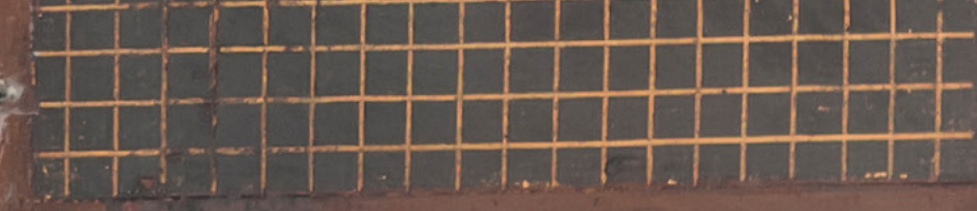



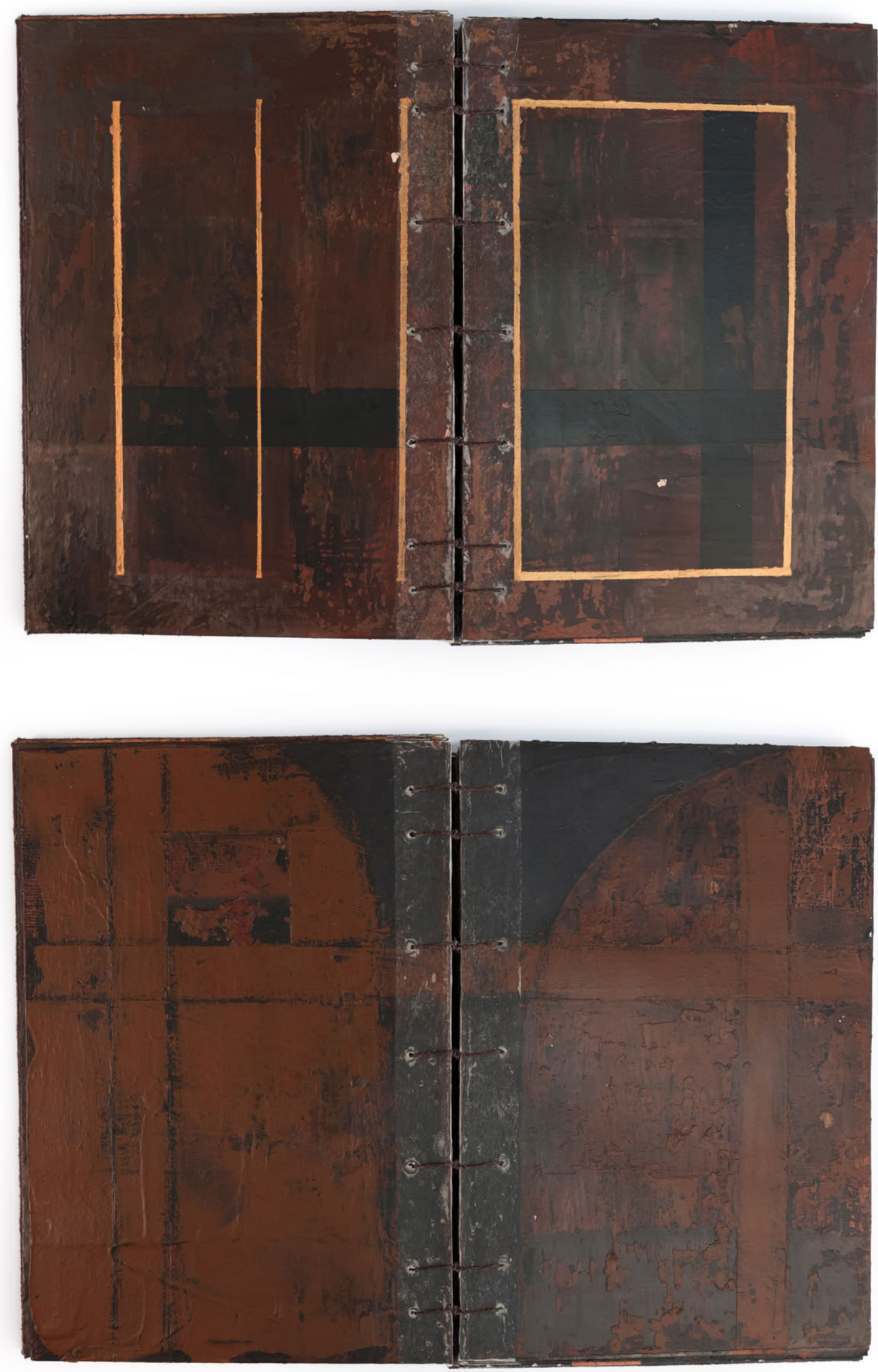

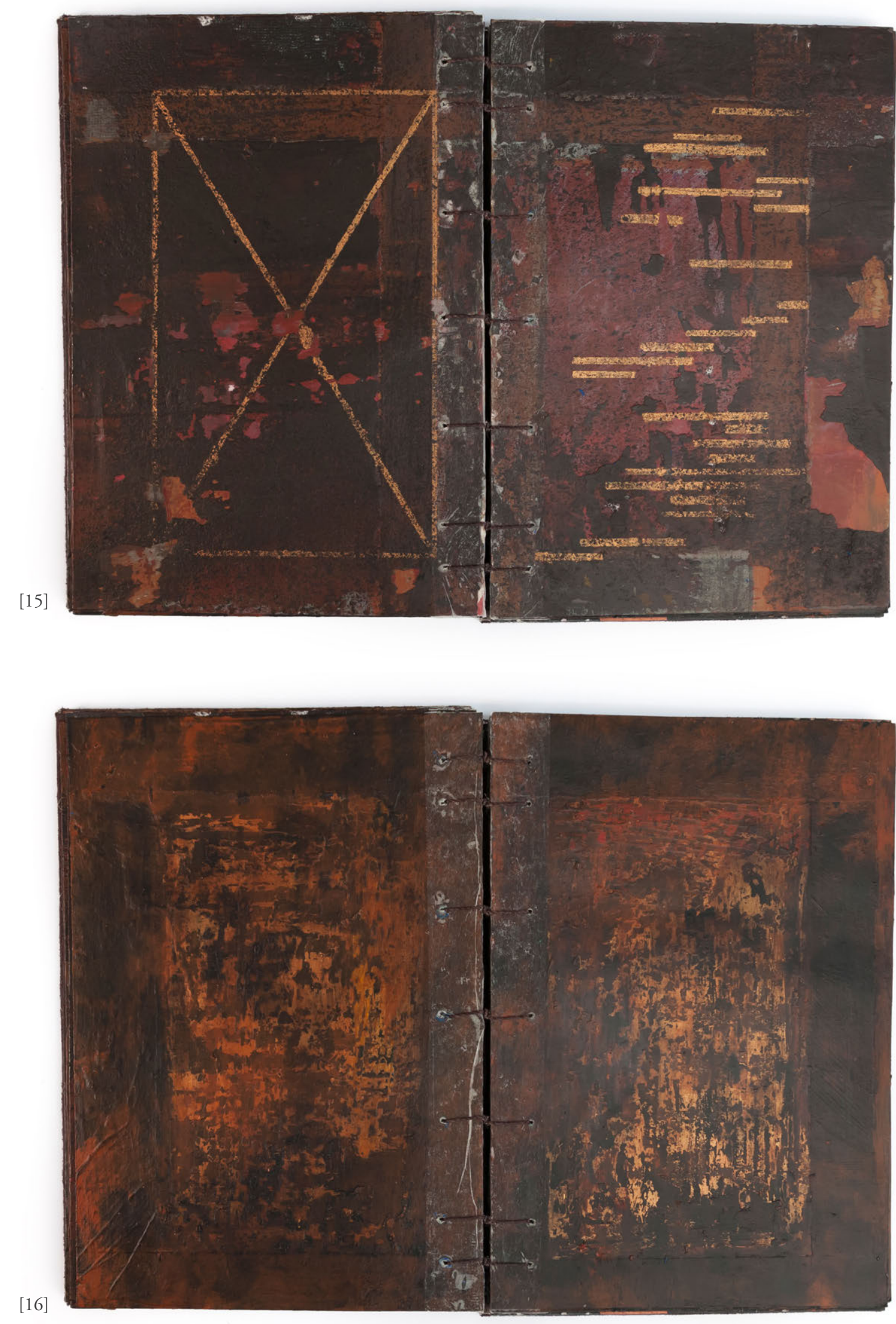


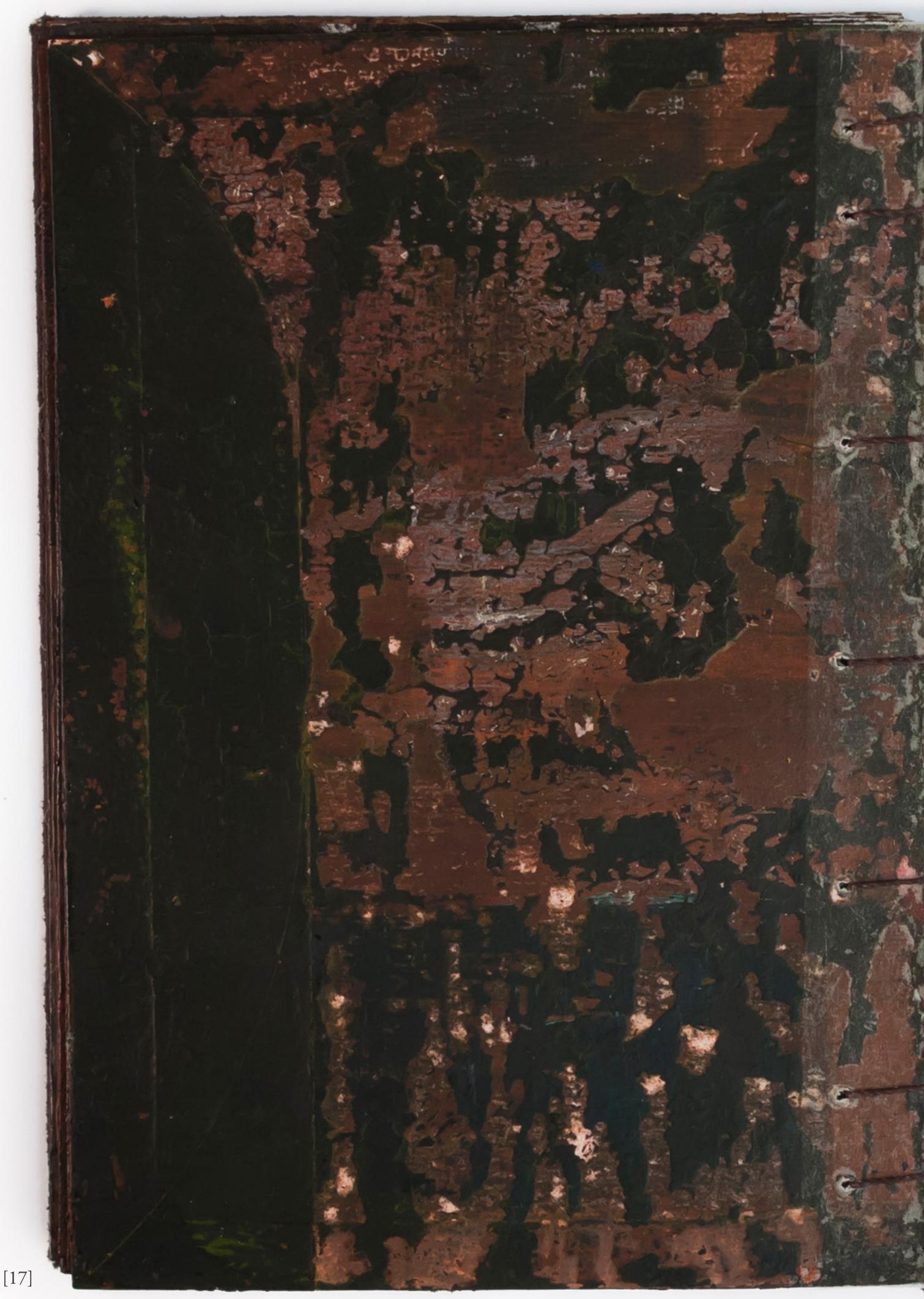




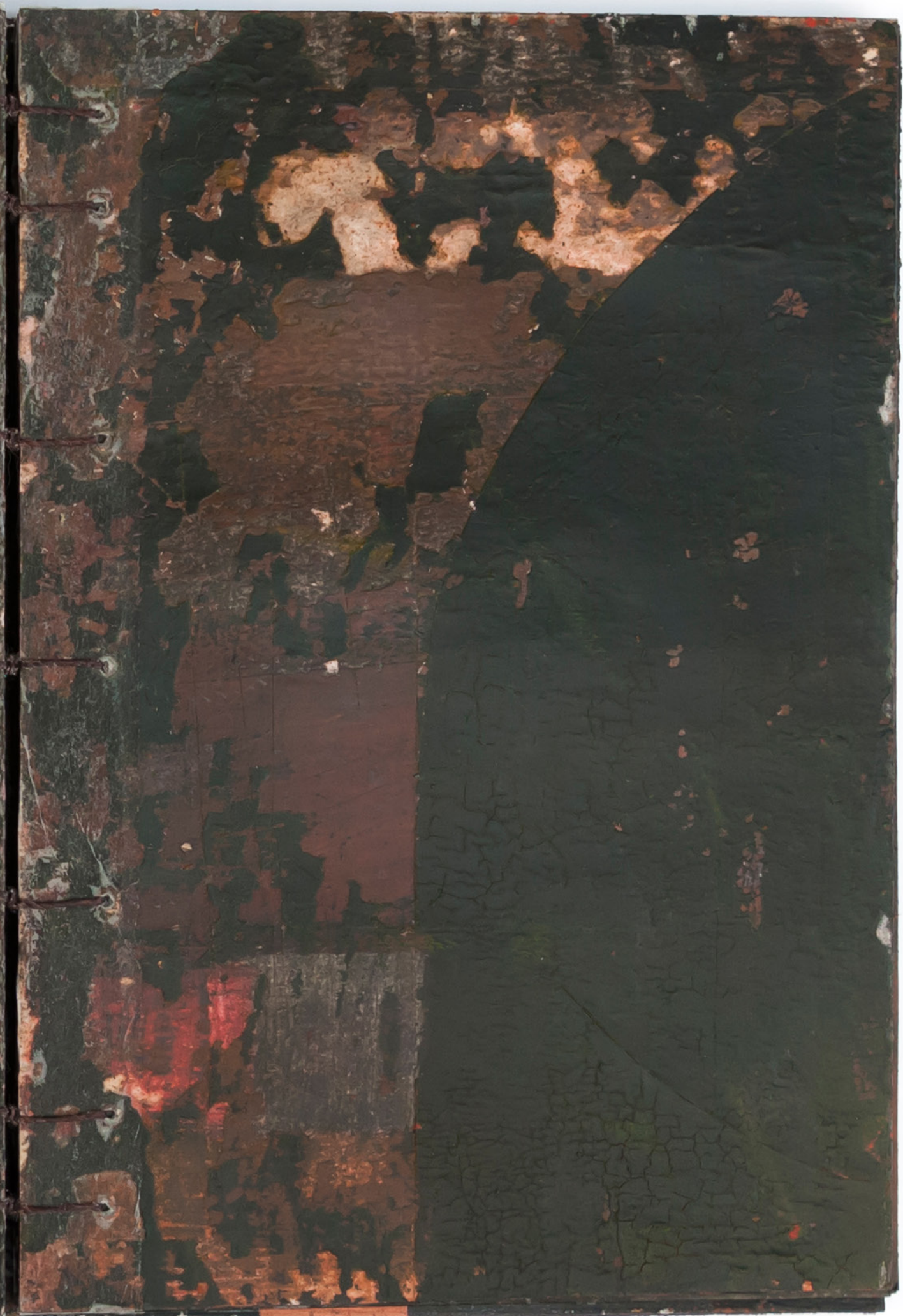



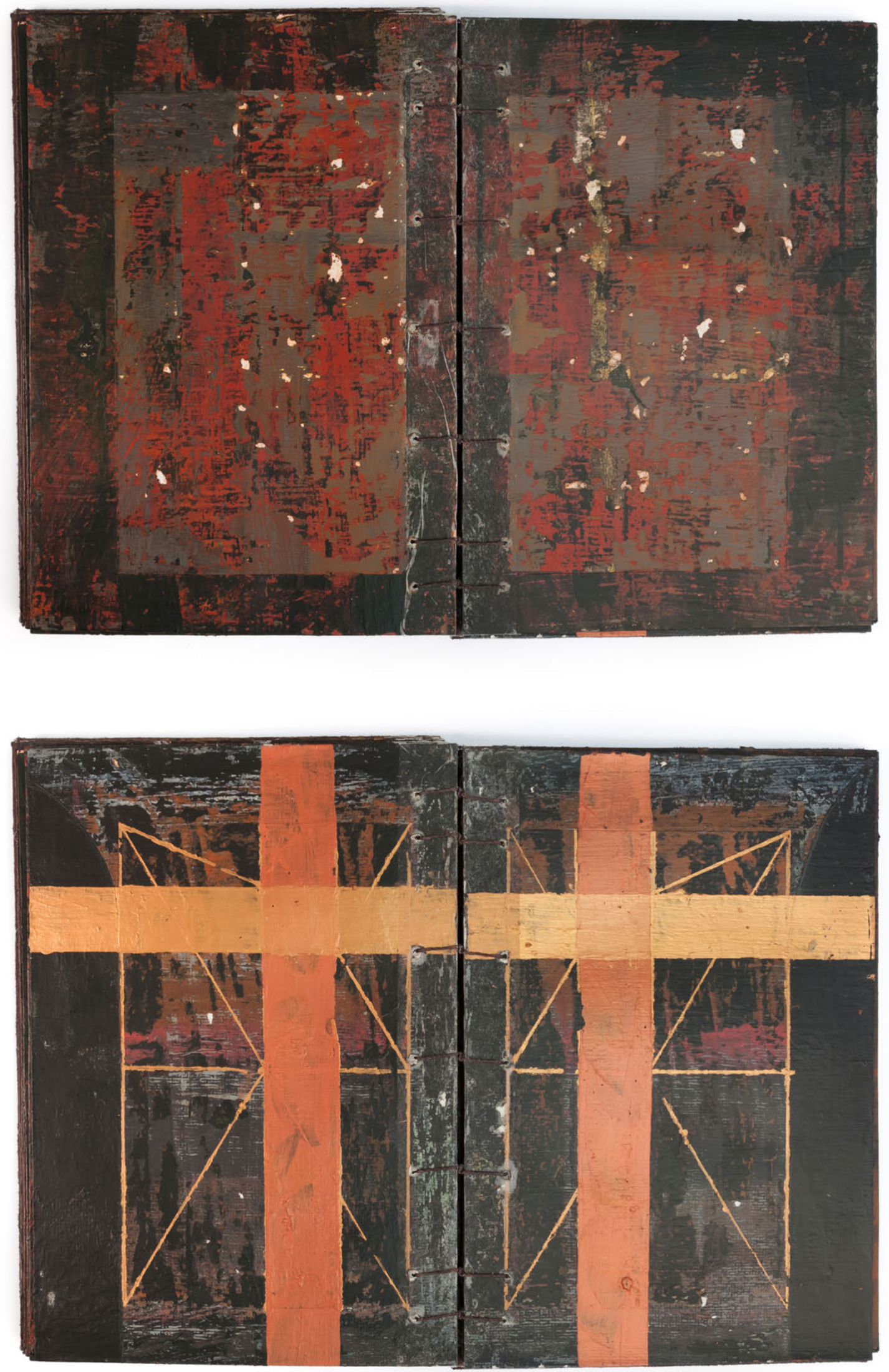

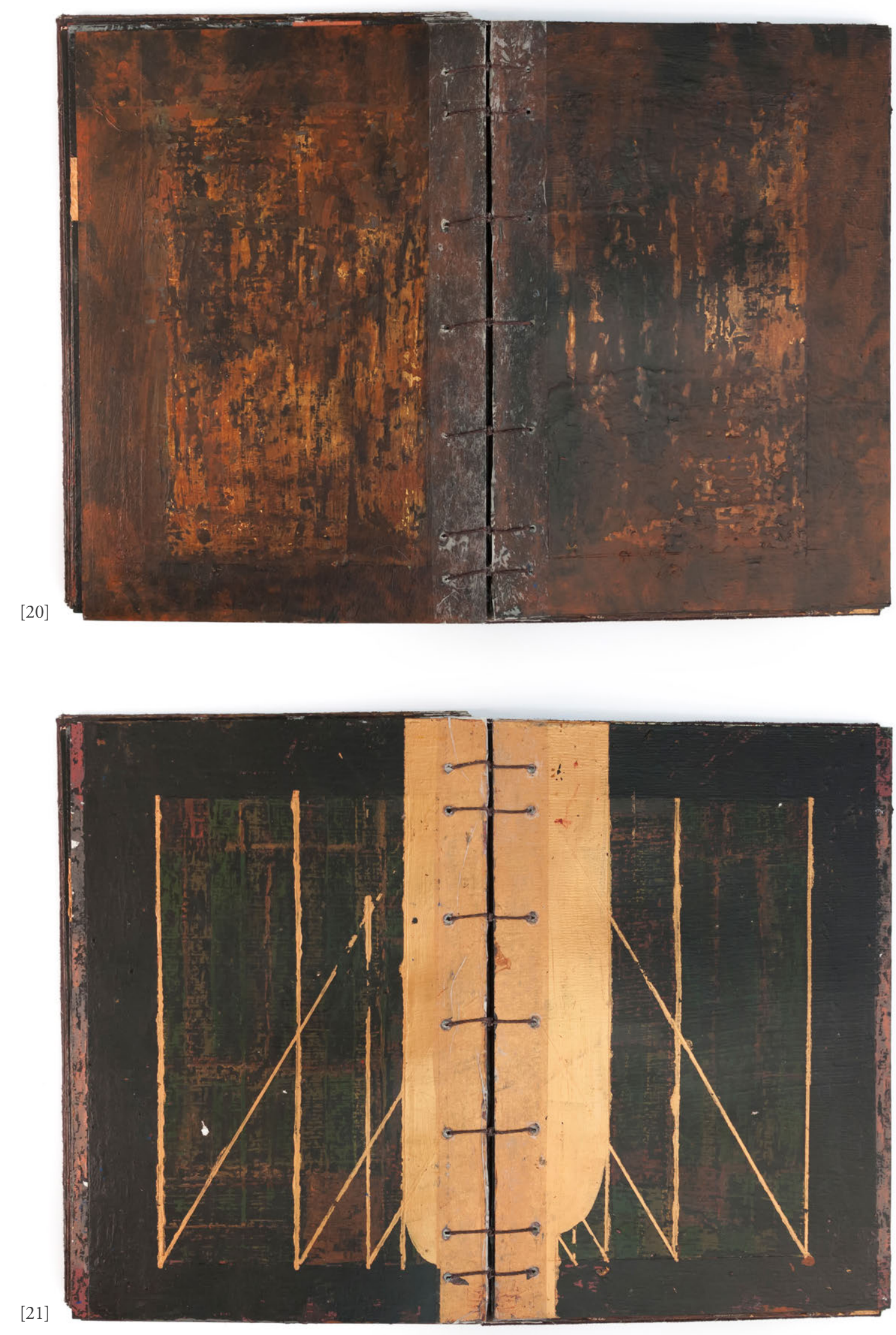

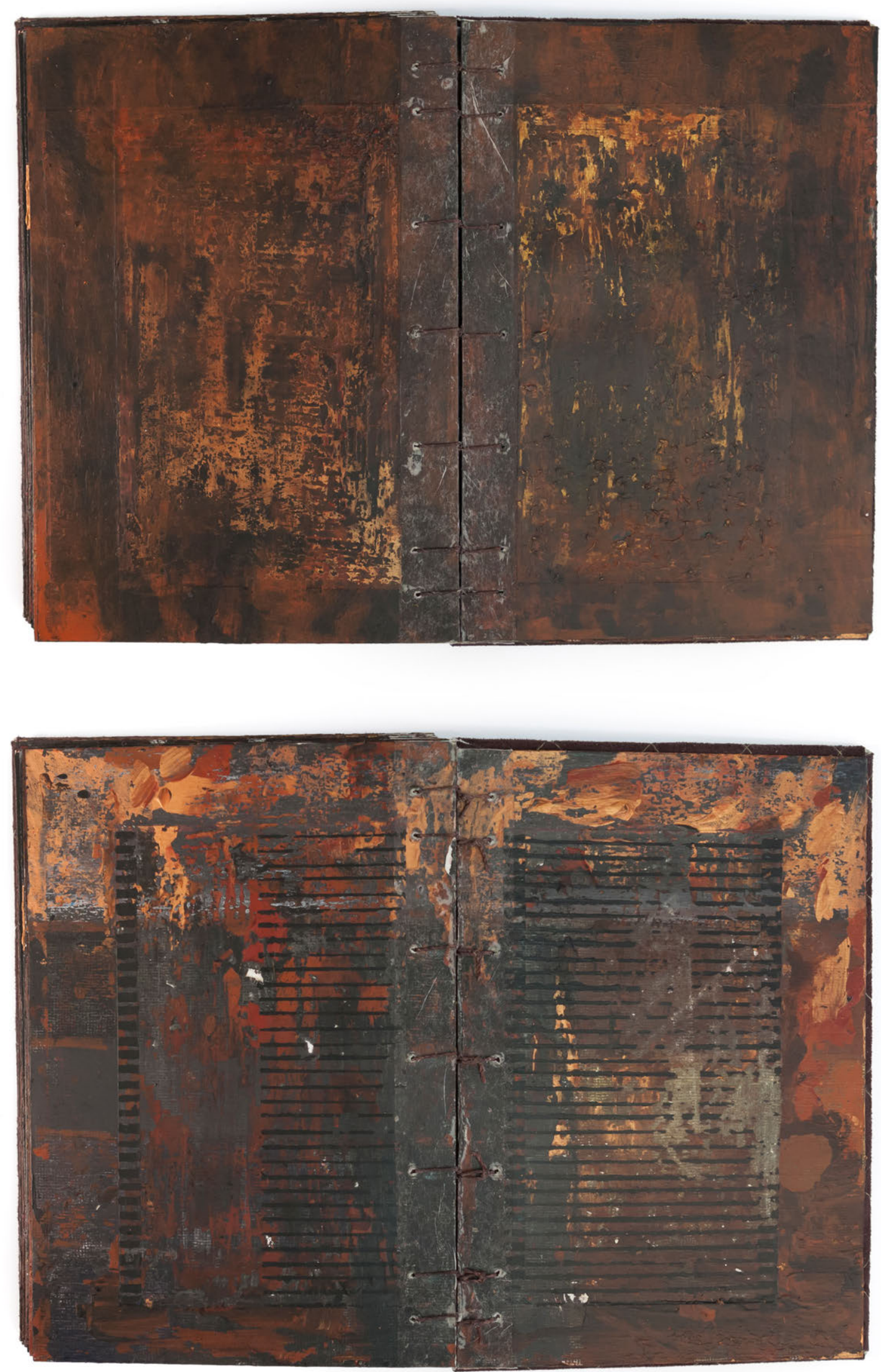


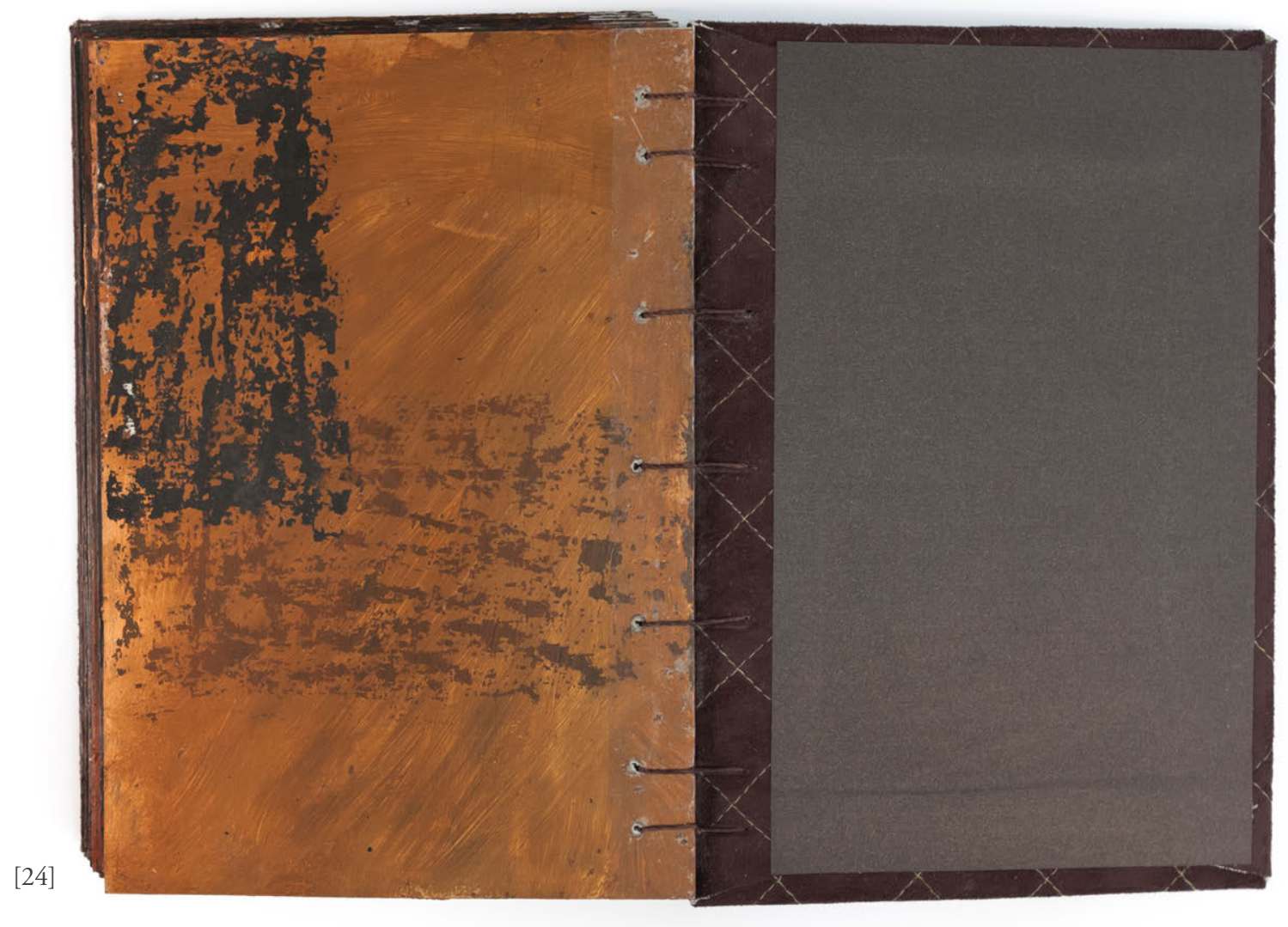

[25]

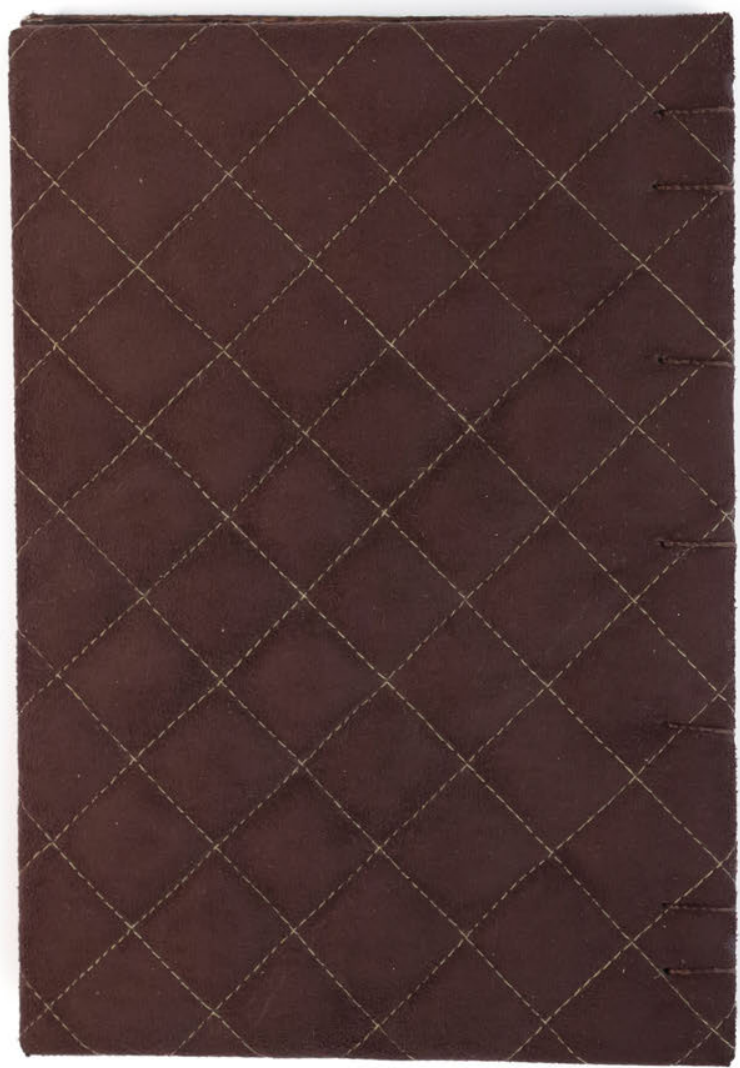



O modelo querido, pelo contrário, move-se; nunca se tem dele mais que instantâneos frustrados. $E u$, na verdade, não sabia mais como eram as feiçóes de Gilberte, salvo nos momentos divinos em que elas se abriam para mim; só me lembrava do seu sorriso. E como não podia ver, por mais esforços que fizesse para recordá-lo, aquele rosto querido, irritava-me ao encontrar na memória, com definitiva exatidão, as caras inuiteis e incisivas do homem do carrossel e da vendedora de pirulitos, como acontece com essas pessoas que perderam um ente querido e não conseguem vê-lo em sonhos, e exasperam-se por encontrar continuamente em seus sonhos tantas criaturas insuportáveis a quem já é demais ter visto em estado de vigília.

Proust, Marcel. Em Busca do Tempo Perdido : À sombra das raparigas em flor, 88-89. 





\section{CÓDICE N.2}

Em geral, as recordaçôes são muito caras às pessoas. Não se deve ao acaso o fato de estarem sempre envolvidas por um colorido poético. As mais belas lembranças são as da infância. Antes de tornar-se o fundamento de uma reelaboração artística do passado, a memória deve, certamente, ser trabalhada; e, nesse caso, é importante não perder a atmosfera emocional especifica sem a qual uma lembrança evocada em todos os seus pormenores nada mais faz a não ser provocar um amargo sentimento de decepção. Existe, afinal, uma enorme diferença entre a maneira como nos lembramos da casa onde nascemos e que não vemos há muitos anos, e a visäo concreta que se tem da casa depois de uma prolongada ausência. Em geral, a poesia da memória é destruida pela confrontaçáo com aquilo que lhe deu origem. ${ }^{29}$

Ao tentar olhar minhas memórias e resgatar o tempo suspenso, quanto mais foco e direciono minha visão, menos nítida se torna a imagem buscada. É na vi-

${ }^{29}$ Andrei Tarkovski, Esculpir o tempo, trad. Jefferson Luiz Camargo, 3o ed (São Paulo: Martins Martins Fontes, 2010), 29-30. 
são sem um foco específico que, não intencionalmente, enxergo de modo mais amplo, ao contrário de quando desejo ver algo em seus mínimos detalhes. Nesse modo, a falta de desejo por direcionar a rememoração possibilita a amplidão da imagem revivida, mesmo que sem detalhes. A poética do tempo suspenso esbarra na memória, em momentos nos quais ela abriga a dilatação temporal.

Em Códice n.2 a questão da memória, em especial a maneira aparentemente aleatória com que ela opera, é adentrada como meio para a manifestação poética. $\mathrm{Na}$ intenção de me embrenhar nesse espaço, recorri a processos de palimpsesto para gerar profundidade na pintura; são linguagens conservadas a partir de composiçôes presentes em Códice n.1.

Nesse sentido, a suspensão do tempo encontra abrigo ao se materializar em pintura onde diversas camadas coabitam uma superfície. Ali, o vagaroso fluir temporal é visualmente palpável, assim como em uma parede descascada, onde para existir a pintura foi preciso tanto a aplicaçẫo das diversas camadas, quanto a sua remoção assim aglutinando, em sinuosas sobreposiçóes, o longo tempo transcorrido durante o processo. Desse modo, as pinturas rompem a sucessão de passado, presente e futuro, para manifestar, em apenas um instante, a totalidade vivida pela superfície.

Culturalmente associado à leitura transcorrida de página em página, do começo ao fim do livro, mesmo quando sua estrutura é explorada por saltos entre as páginas, como em dicionários ou enciclopédias, o encadeamento natural do códice dá-se na linearidade. Justamente ela é rompida por Kiefer em seu livro Kühlstaub, ${ }^{30}$ e adentrada pelo Códice n.2. No trabalho de Kiefer, o conteúdo é composto por sucessivas páginas duplas formadas por fotografias semelhantes de uma floresta com neve prateada. Apenas nas orelhas da sobrecapa se encontram pequenos textos, em especial a orelha envolvendo a segunda capa. Como na entrada de uma

\footnotetext{
${ }^{30}$ Anselm Kiefer, Kühlstaub (Hanôver, Alemanha: Edition Heiner Bastian, 2014).
} 
exposição, ali há um pequeno texto contextualizando a obra com a qual o leitor travará contato. Segue a transcrição:

\begin{abstract}
ANSELM KIEFER
Kühlstaub

The title "Kühlstaub" refers to a metaphor from Hermann Broch's novel "The Death of Virgil«. In this book, Broch describes the last hours of the Roman poet, who ponders about the meaning of the literary, artistic life. While once looking at the starry sky, he speaks of the "... remote dark breeze of the Stony cold..." [abgeschiedenen dunklen Hauch des kühlsteinernen] and the "...dusty chill of the Eastern moonlight..." [dem staubkühlen des östlichen Mondlichts]. These metaphoric thoughts are translated by Kiefer into images of snow nocturnal winter forests. ${ }^{31}$
\end{abstract}

Exceto na primeira e na quarta capa, as tais fotomontagens de árvores com manchas prateadas ocupam todas as duplas, incluindo as páginas de guarda. Se num primeiro momento segue-se lendo linearmente o livro, após algumas viradas de página fica clara a repetição de seu conteúdo. Somos visitantes andando desnorteados por entre as árvores de um bosque em meio a uma tempestade de neve. Às vezes a visão é cegada por grandes quantidades de gelo; outras vezes, nos deparamos com largos troncos a poucos palmos de distância. O olhar para

\footnotetext{
31 “ANSELM KIEFER / Küblstaub / O titulo "Kühlstaub" se refere à metáfora do romance de Hermann Broch "The Death of Virgilu. Neste livro, Broch descreve as uiltimas horas do poeta Romano, que pondera sobre o sentido da vida literária, artística. Enquanto olha para o céu estrelado, ele discursa sobre a "... remota brisa negra de Stony cold... « [abgeschiedenen dunklen Hauch des kühlsteinernen] e sobre "...o frio empoeirado do luar oriental..." [dem staubkühlen des östlichen Mondlichts]. Esses pensamentos metafóricos são traduzidos por Kiefer em imagens de neve em uma invernal floresta noturna." Ibidem, nossa traduçấo.
} 
o céu busca um alívio no interior da incessante desordem. Mesmo sendo possível, por um momento, ver uma colina distante, ainda estamos imersos em um ambiente completamente igual e repetitivo para alguém pouco familiarizado com suas peculiaridades.

A leitura de Kühlstaub (2014) não é linear, independentemente da página por onde se inicie a leitura, e para qual sentido ela siga, o único sentido definido é a orientação vertical do livro, revelado pela imagem da floresta. Aparentemente simples, o livro rompe a maneira usual de manusear o códice, sem para isso recorrer a formatos inusitados, diferentes materiais, texturas, transparências ou dobras. Dessa forma, a leitura iniciada com o costumeiro virar de páginas em sequência logo se desapega do folhear tradicional. Em qualquer sentido que tome, o leitor continuará imerso e desorientado por entre as copas.

Análogo à floresta de Anselm Kiefer, os meandros da memória são desconhecidos. Sem direção ou norte, seus desvios não possuem começo, meio ou fim. Modelado em associações aparentemente aleatórias e pouco nítidas, Códice n.2 é composto por camadas de tinta, fotografias e desenhos utilizando sobreposiçôes e raspagens. Destituídas de sentido de leitura definida, as imagens se posicionam a cada momento em uma direção, exigindo a rotaçâo do objeto durante a leitura aleatória das páginas, na construção de um espaço no imaginário.

Com sucessivas camadas sobrepostas, as páginas do livro são ricas em texturas e tonalidades de pretos - opacos, profundos, lisos e ásperos -, marrons, vermelhos e cobre. Em suas sobreposiçóes, notam-se camadas densas de tinta craquelada ou diluída, a ponto de se perceber a trama do tecido, as quais formam geometrias que escorrem em variados sentidos. Por entre as manchas, desenhos surgem delineados por traços e fotografias incompletas. Por fim, sobre o denso conjunto de camadas, uma superfície heterogênea, de aspecto leitoso, turva a visão da superfície. 


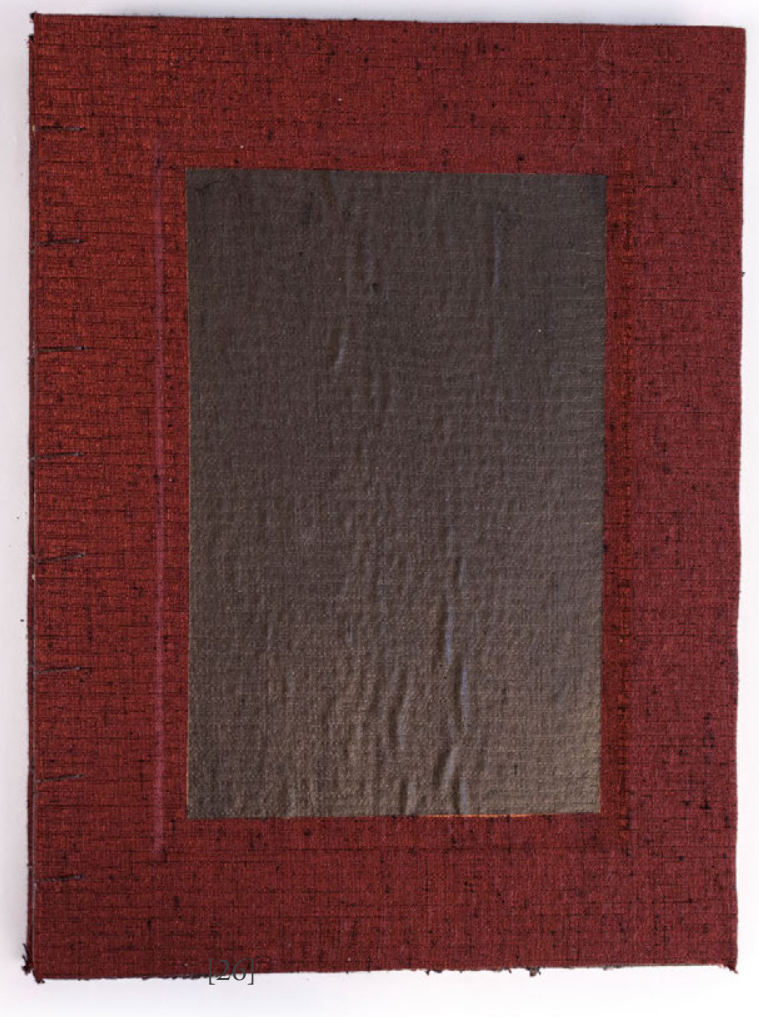

\section{CÓDICE N.2}

Técnica mista (tela, tecido, papel vegetal, linha encerada, tinta acrílica, giz pastel oleoso, giz pastel seco, verniz, resina, carvão, fotografias, folhas).

$24,6 \times 32,5 \mathrm{~cm}$ (fechado)

$49,3 \times 32,5 \mathrm{~cm}$ (aberto)

2016

(Ver DVD anexo) 

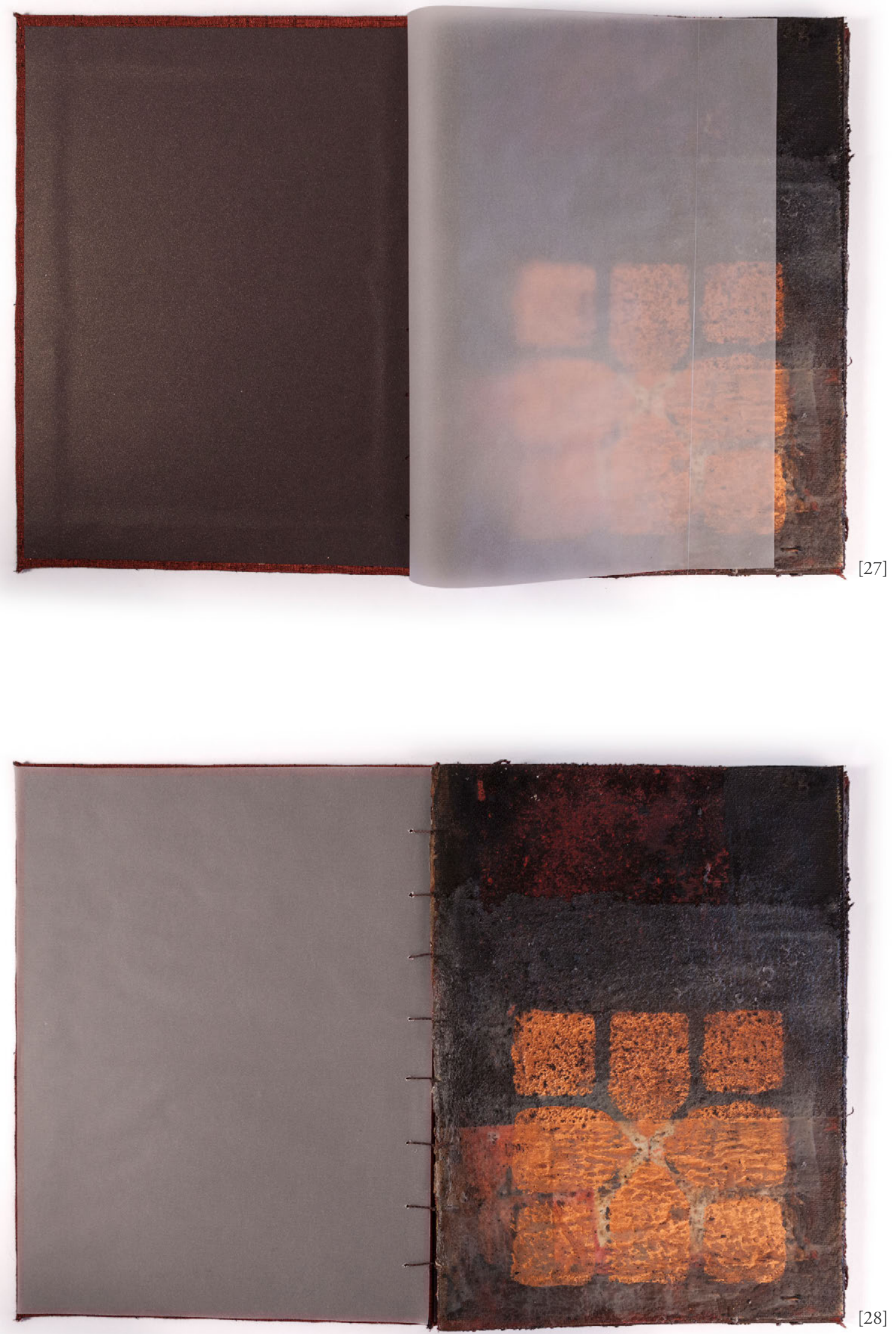

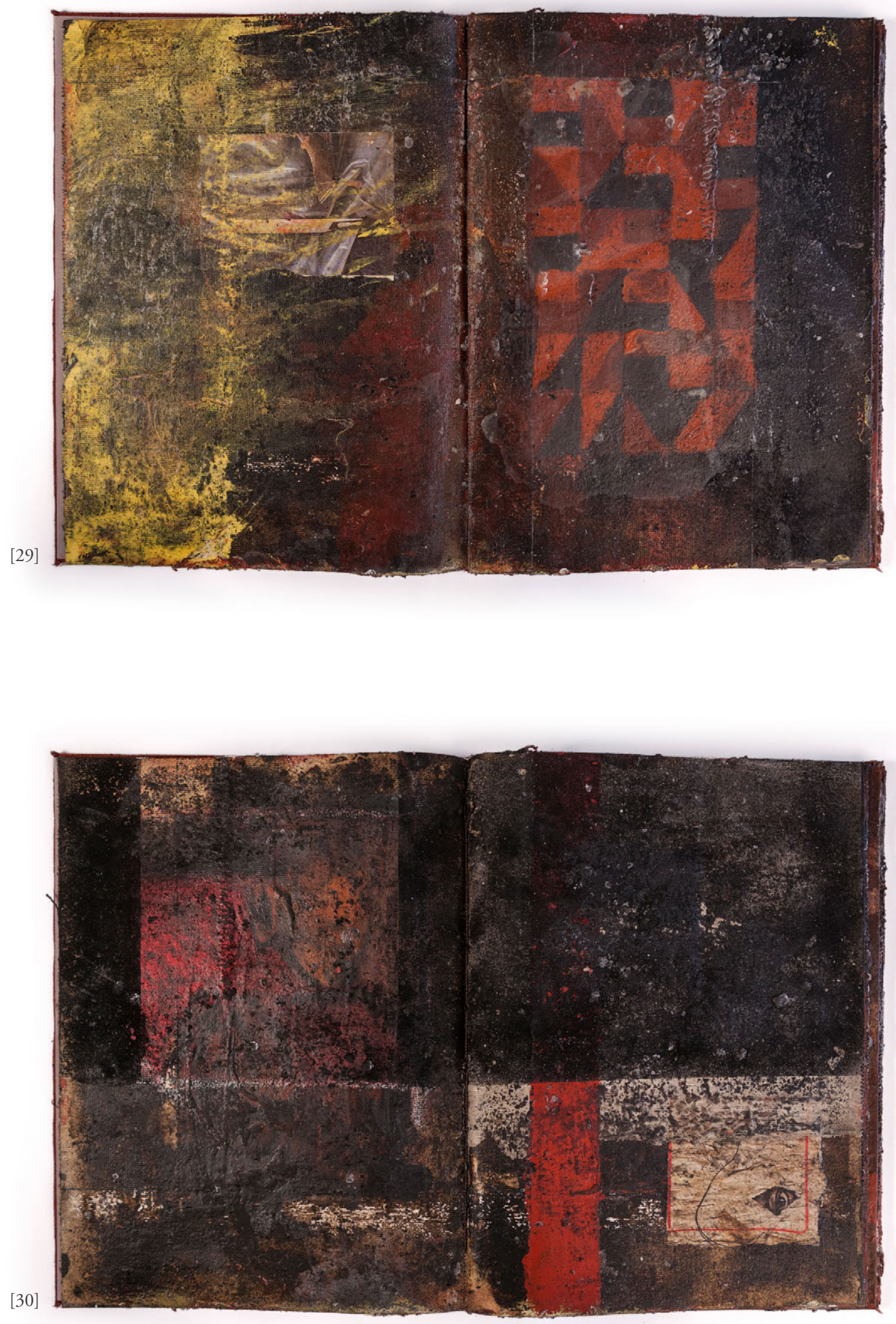


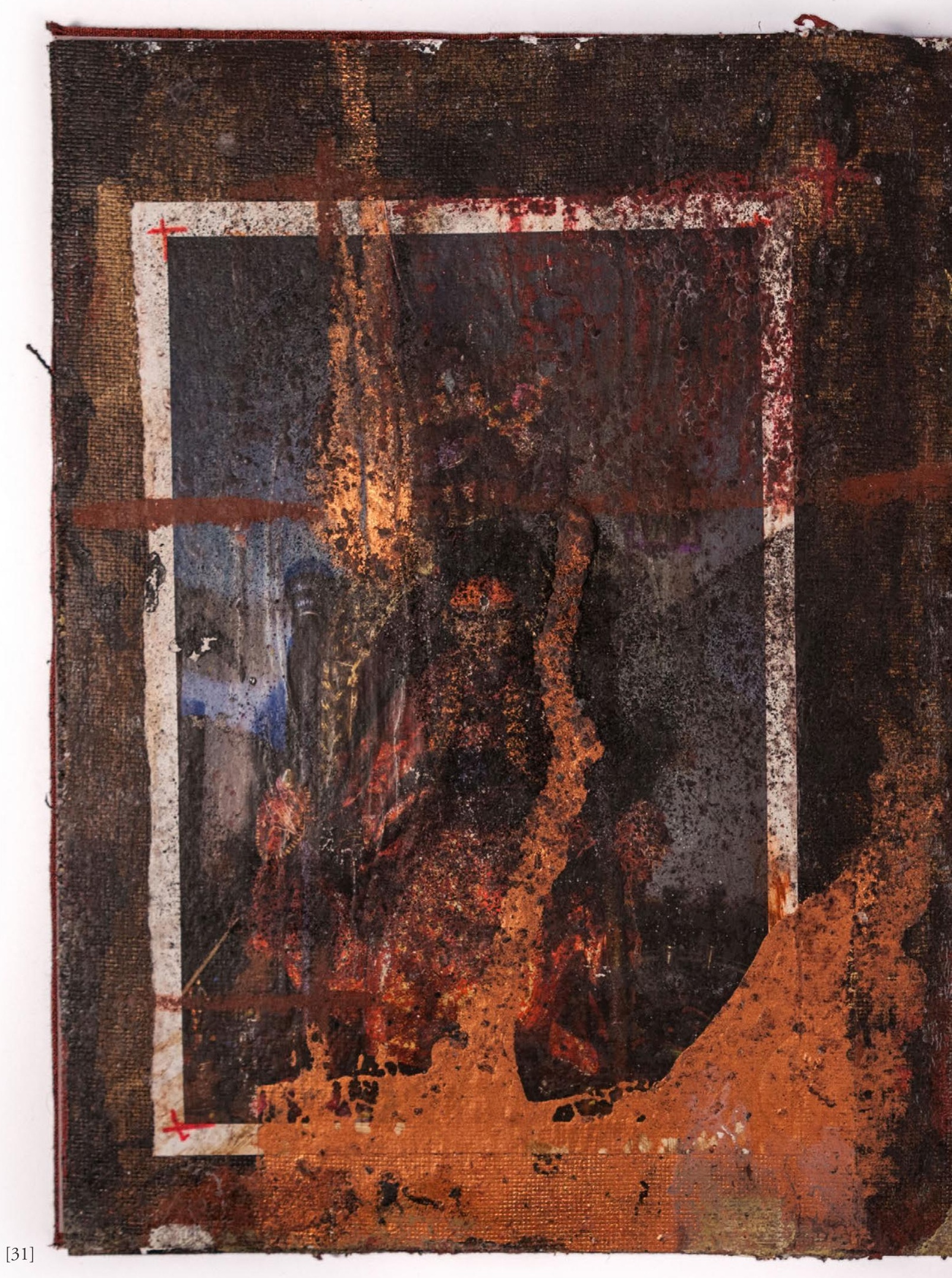




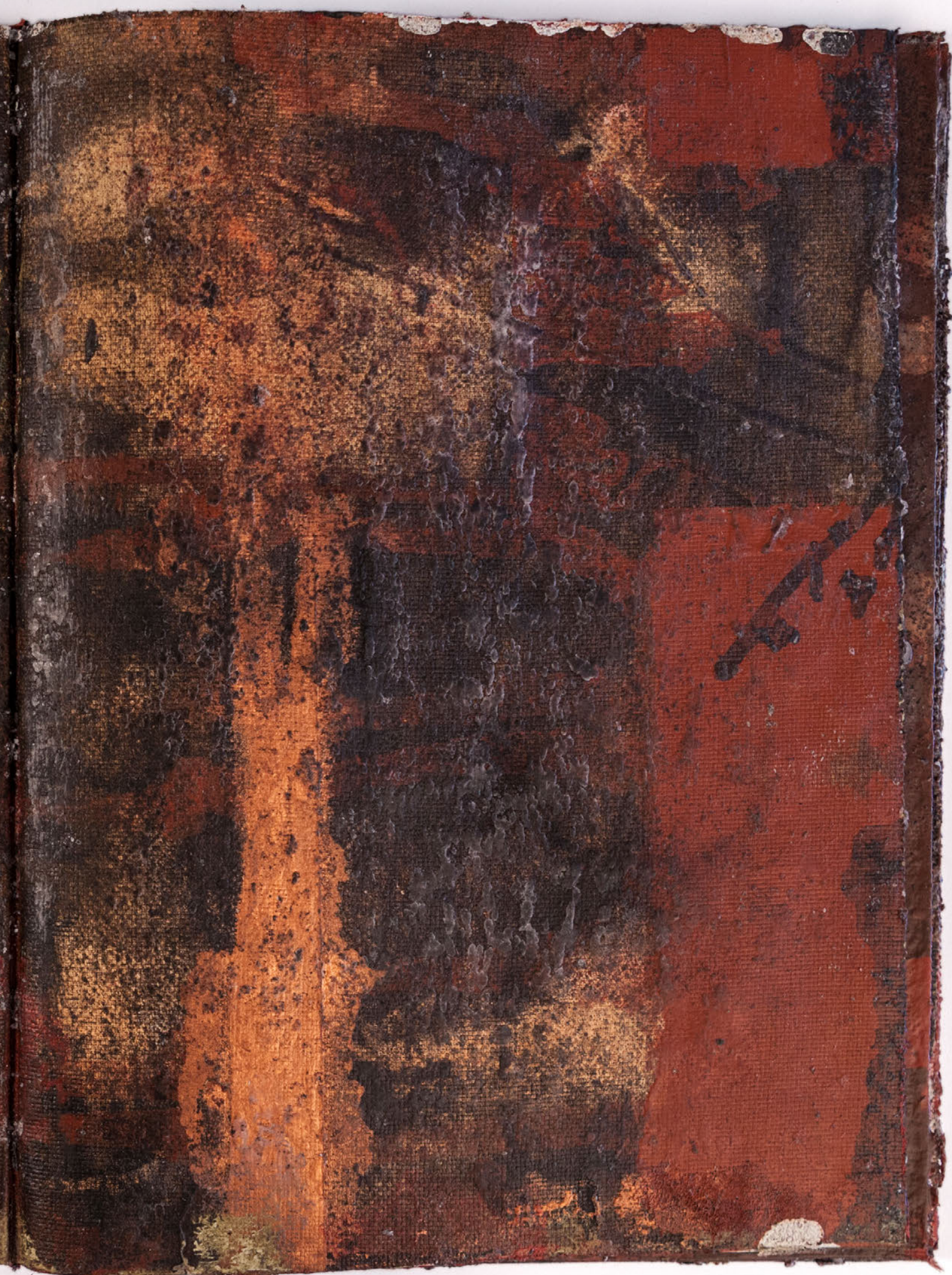



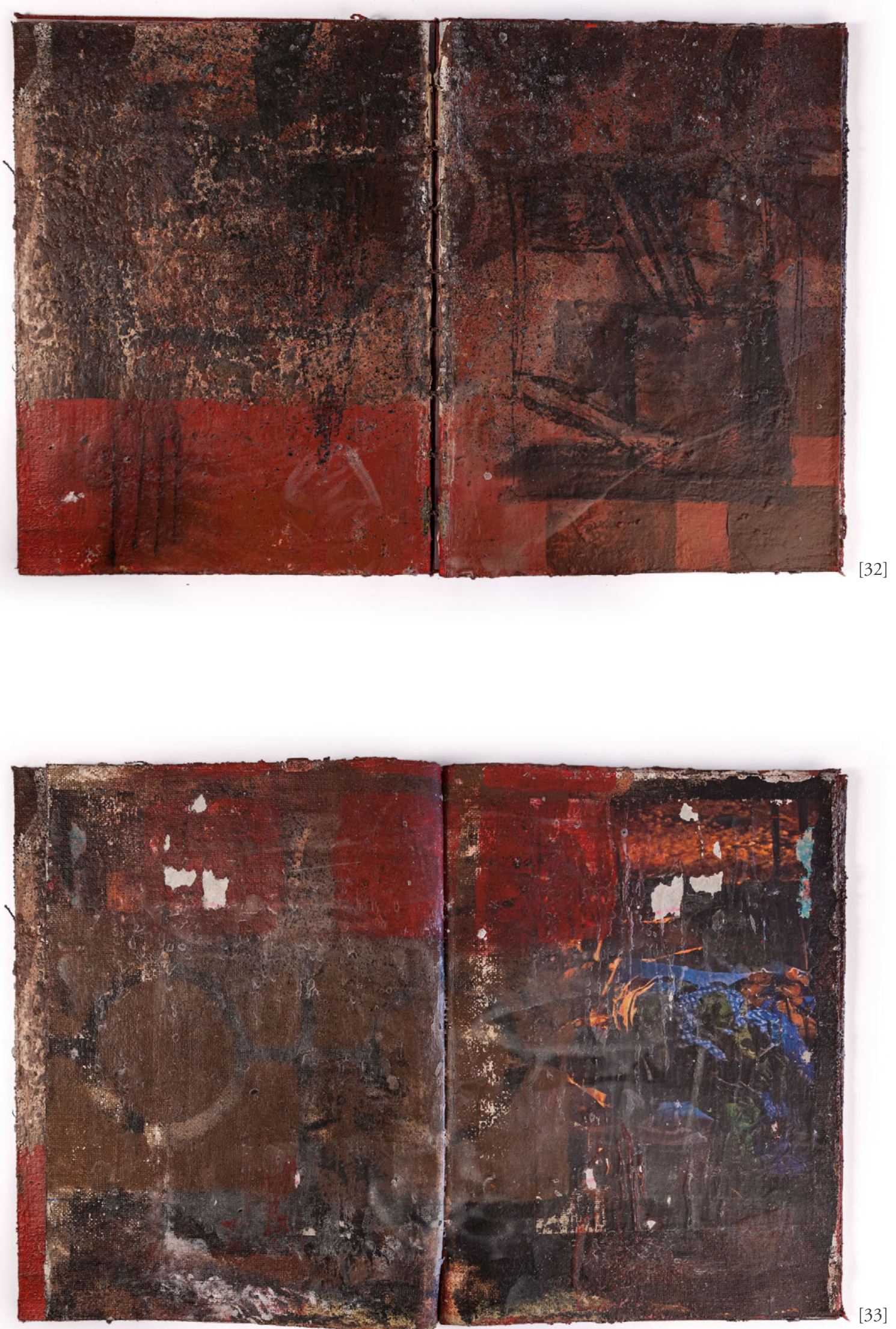

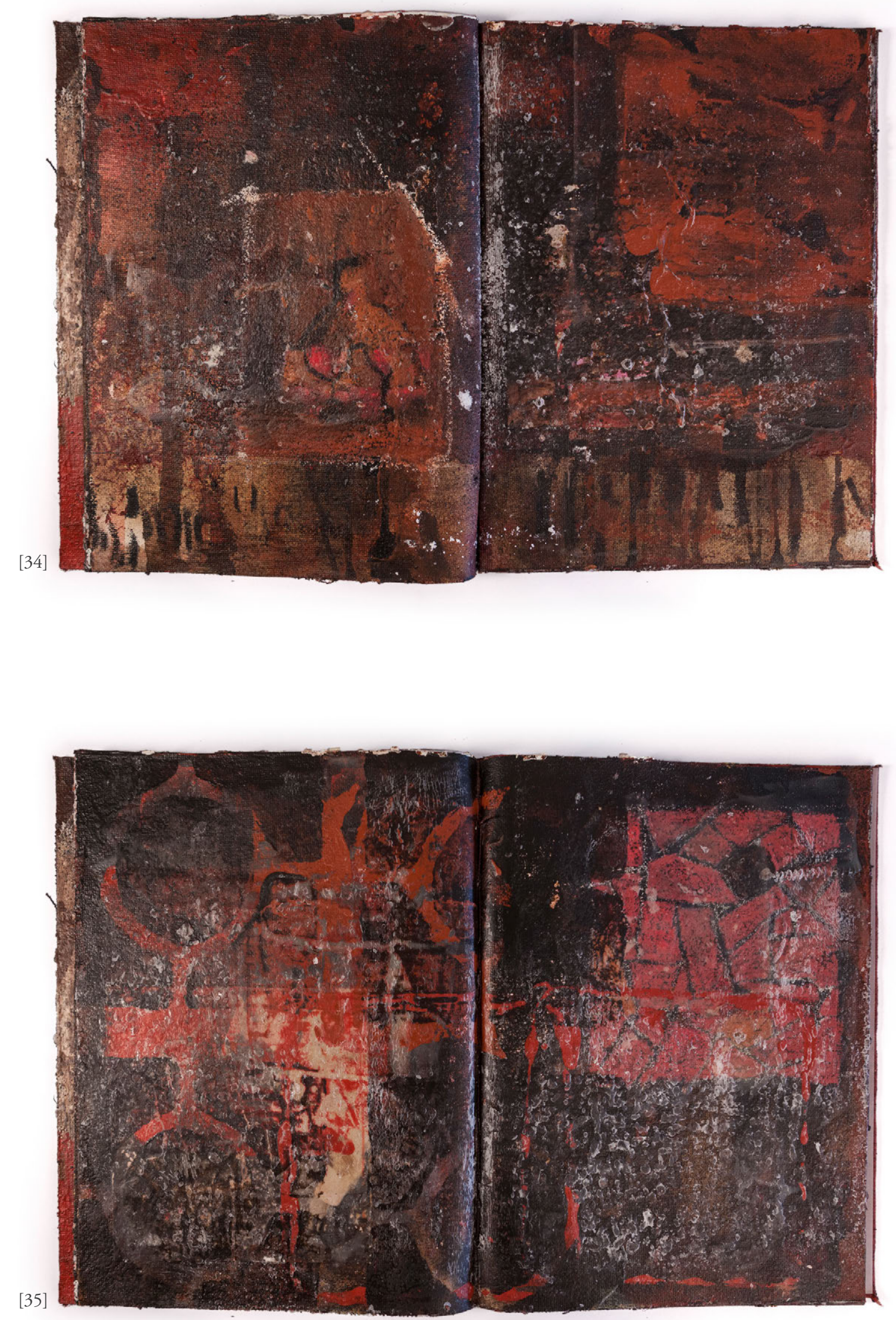


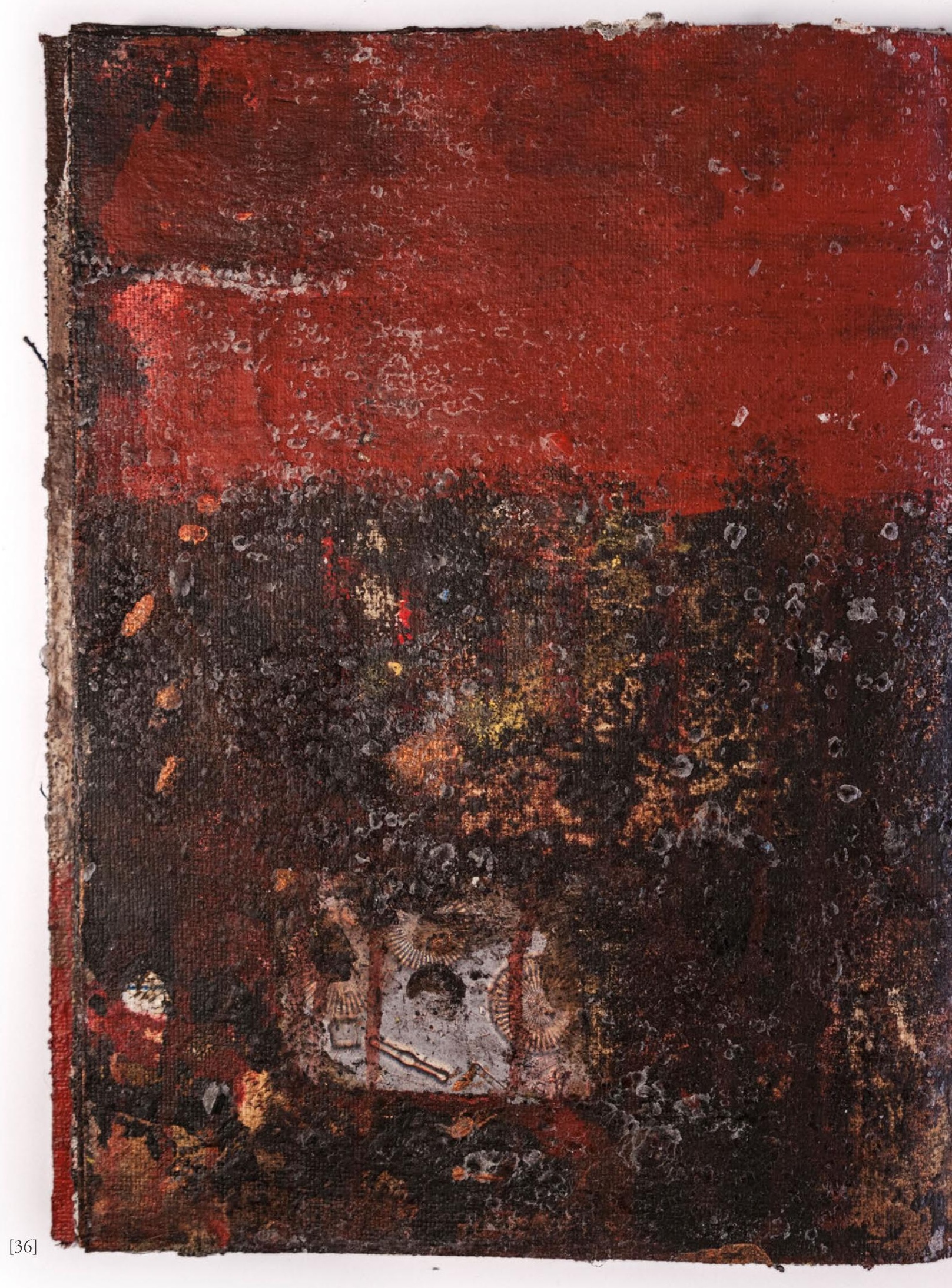




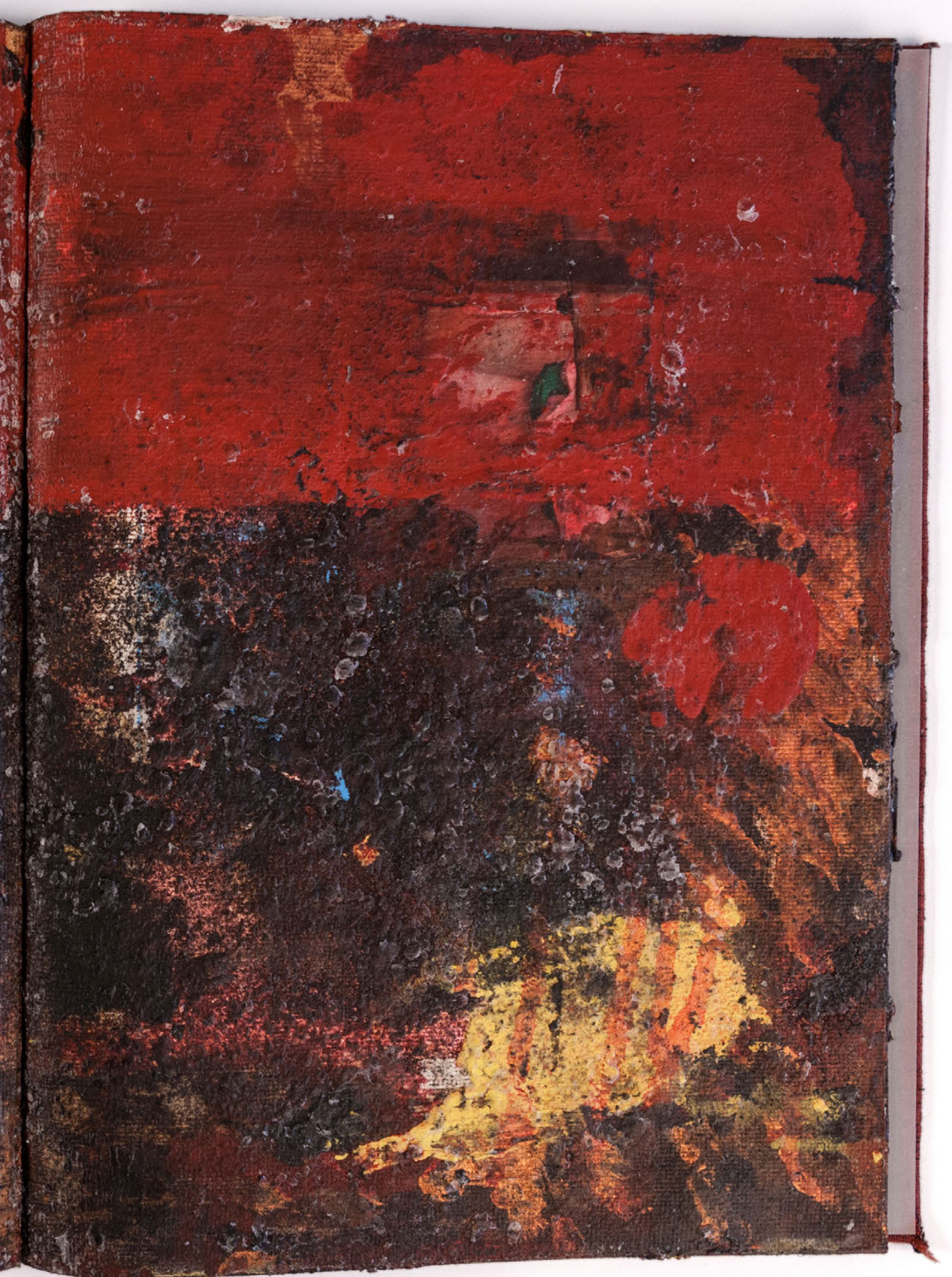



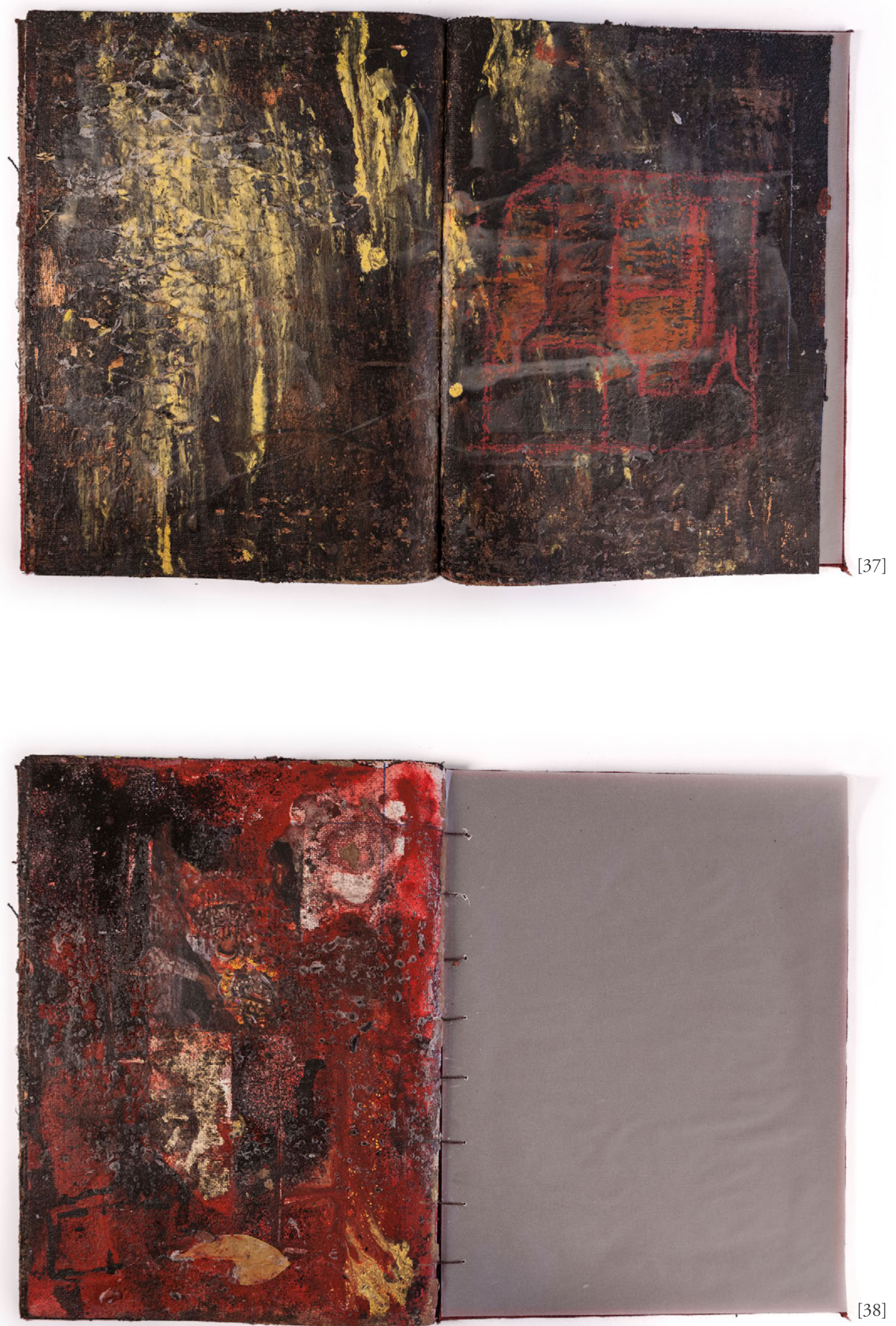

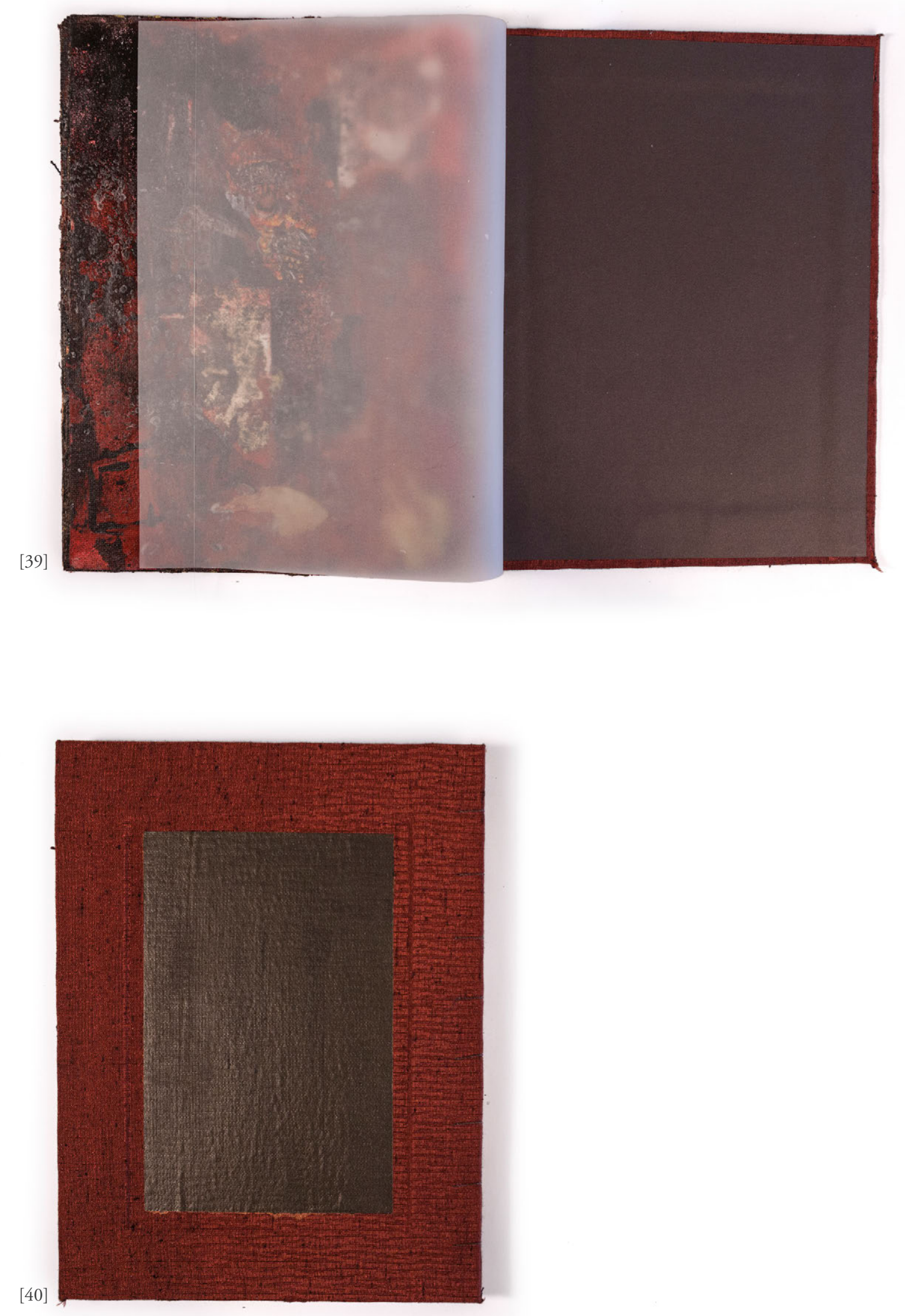

Mas naquela manhã de viagem, a interrupção da rotina de minha existência, a mudança de lugar e de hora tornaram indispensável a presença de minhas faculdades. Meu hábito, que era sedentário e nada madrugador, estava ausente, e todas as minhas faculdades haviam acorrido para substitui-lo, rivalizando entre si em zelo - elevando-se todas, como vagas, a um mesmo nivel inacostumado - da mais baixa à mais nobre, da respiração, da fome e da circulação sanguínea à sensibilidade e à imaginação.

Proust, Marcel. Em Busca do Tempo Perdido: À sombra das raparigas em flor, 282. 





\section{CÓDICE N.3}

Platáo disse que o tempo é a imagem móvel da eternidade. Ele começa por eternidade, por um ser eterno, e esse ser eterno almeja projetar-se em outros seres. E não pode fazê-lo em sua eternidade: tem de fazê-lo sucessivamente. O tempo vem a ser a imagem móvel da eternidade. (...) Se nos mostrassem o ser de uma vez só ficaríamos aniquilados, anulados, mortos. O tempo, em compensação, é a dádiva da eternidade. A eternidade nos permite todas essas experiências de maneira sucessiva. Temos dias e noites, temos horas, temos minutos, temos memória, temos as sensaçóes atuais, e depois temos o futuro, um futuro cuja forma ainda ignoramos, mas que pressentimos ou tememos. ${ }^{32}$

Preenchido por bibelôs, toalhas de crochê, santos e porta-retratos com antigas fotografias coloridas por pincéis, o quarto de meus avós presente em minha memória ocupa um espaço distinto na apreciação do tempo suspenso. A passagem do tempo é perceptível no tom escurecido da madeira do chão de tacos e

32 Jorge Luis Borges, Borges oral \& Sete noites (São Paulo: Companhia das Letras, 2011), 69-70. 
dos móveis, lentamente coberta por camadas de pátina oleosa de poeira e cera, acumulada constantemente por anos de uso. Naquele ambiente familiar pouco conhecido, onde, apesar de nunca me ter sido negado frequentá-lo, me sentia um intruso, penetrava em um vazio momentâneo, abrindo espaço para cada pequena forma, sombra, cor, luz ou som me atingir intensamente.

Apesar de habitado por meus avós, o quarto rememorado está sempre vazio e encoberto em penumbra. Nele convivo com o silêncio. Um rastro de luz adentra pela janela e evidencia em seu caminho a poeira suspensa: nem pesada o bastante para cair, nem leve o suficiente para subir. Flutua no ar em uma eterna espera pela mudança porvir. Assim como no lar de inúmeras outras famílias católicas, um volume da Bíblia se encontrava aberto em cima de uma antiga cômoda, apoiada em uma toalha branca de renda. Apesar de eu pouco saber sobre religião, esse livro abriga um respeito que não devo romper; o sacro em meio ao ambiente cotidiano. Quando vazio, noto naquele quarto a riqueza dos sons efêmeros: o assobiar da panela de pressão, o ladrar de cães, as conversas no vizinho, o passar de rodas no paralelepípedo da rua ao lado, o apito no estacionamento de trens. Pela janela, posso ver parte da casa a partir de um ângulo pouco usual. Adentrar esse quarto é a imersão em um fluir lento e em uma percepção diferente da passagem do tempo.

A penumbra, ao mesmo tempo que oculta, torna aparente uma maneira de ver distinta da habitual nitidez da luz. Encontro envolto nessa atmosfera o interior de antigas igrejas. Ao adentrá-las, me desloco do ritmo exterior e sou inserido em um momento aparentemente paralisado no qual, aos poucos, em decorrência da desaceleração, minha percepção se tona mais sensível ou, ao menos, mais consciente dos estímulos que me alcançam. A audição, que aqui não é utilizada para me comunicar, uma vez mais percebe sons sempre presentes, mas pouco notados. O mesmo poderia ser dito em relação aos demais sentidos.

No filme O Grande Silêncio (Gröning 2005) a falta de comunicação alcança outra proporção. Nele, o diretor acompanhou a rotina de monges car- 
[41]
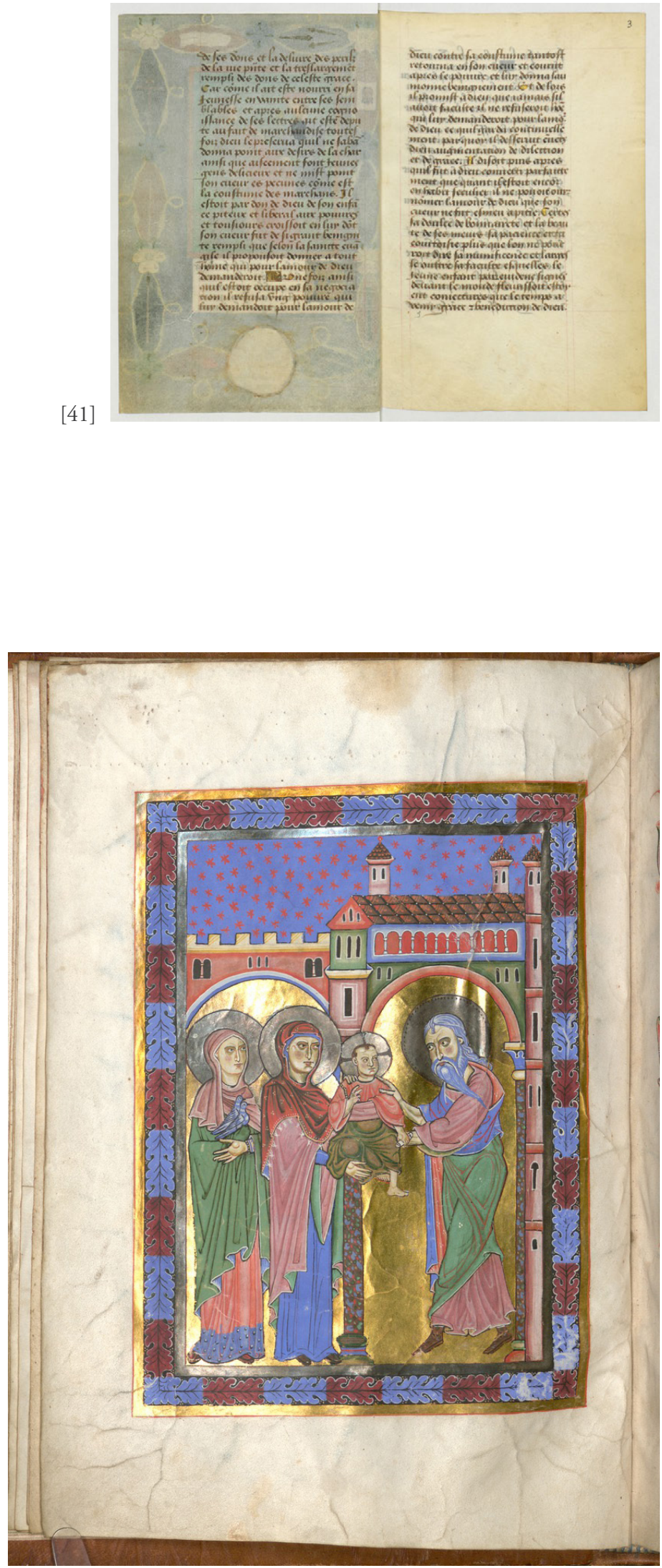

[42] 


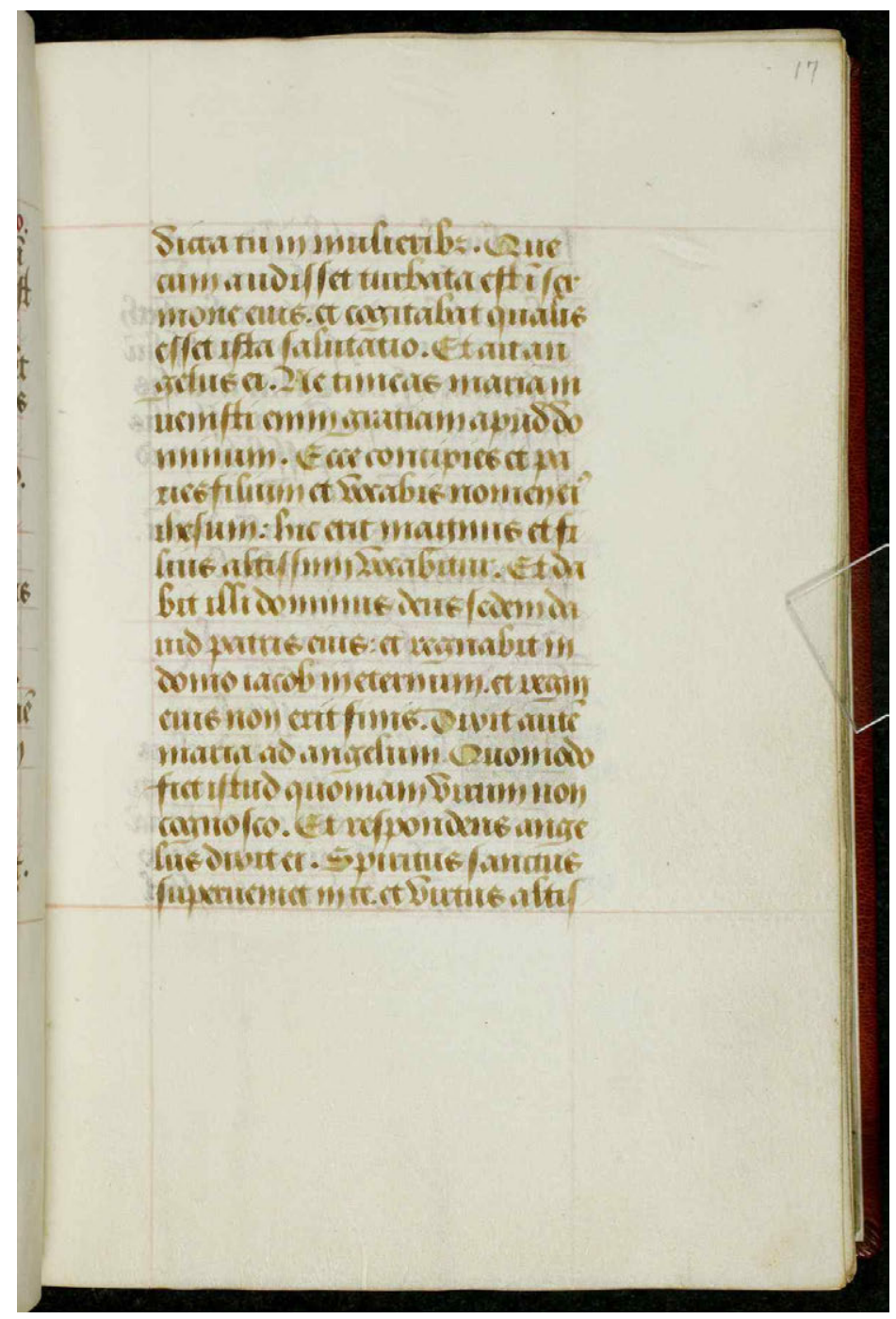

[43] 
tuxos no monastério da Grande Cartuxa, em Grenoble, conhecida por ser a mais austera ordem monástica católica. $\mathrm{O}$ filme segue um ritmo lento por três vagarosas horas, acompanhando rezas e hábitos diários do mosteiro, repleto de contemplação e silêncio em registros sem narração, trilha sonora ou luz artificial. Nesse templo, raros são os diálogos fora do contexto religioso, cotidianamente repetido. Em dada passagem, um monge parece ter adormecido durante uma reza, e o único detalhe que o demonstra desperto é o lento e constante mexer de dedos para mover o terço durante a reza. Esse momento quase estático não é uma exceção, pois há passagens semelhantes registradas com outros monges. Quantos outros tênues acontecimentos não nos escapam durante o ritmo diário, por estarmos de olhos vendados a esse outro tempo? A clausura e o silêncio desses homens parece uma escolha para que possam perceber a vida em suas minúcias.

Encontro na estética dos livros de horas a possibilidade de produzir mais um códice. Esses objetos servem formalmente como fonte de referência para a pesquisa. Com diferentes formas, tamanhos, volumes e acabamentos, são fruto das mãos de pessoas envolvidas em uma produção artesanal. Possuem como função comum o fato de indicarem as preces a serem realizadas ao longo do dia e do ano. ${ }^{33} \mathrm{O}$ conteúdo e refinamento desses objetos varia dependendo dos recursos financeiros de quem os encomendou - possibilitando ou não a produçấo de volumes mais ostentosos e páginas mais elaboradas. Neles, o formato constante da mancha de texto ao longo das páginas explicita o recorte estabelecido para a produção do escriba. Além dessas fronteiras, muitas vezes, rebuscados desenhos emolduram o texto, quando as pinturas não ocupam totalmente, em páginas excepcionais, a superfície com iluminuras religiosas. A organização matemática e a ostentação com ouro são características em comum a diversos livros de horas. Procuro nesses objetos empregados em liturgias rotineiras o silêncio presente em tais rituais.

\footnotetext{
${ }^{33}$ Origem, função, características e exemplos de livros de horas em Martyn Lyons, Livro : uma história viva (São Paulo: Editora Senac São Paulo, 2011), 45-46.
} 
O Códice n.3 é um pequeno volume em capa preta. Seu interior, coberto por um fino papel antes da primeira e depois da última folha, abriga diversas páginas cujo conteúdo é circunscrito por uma moldura cobre. Em seu interior, um retângulo azul com linhas horizontais borradas ou, em menor proporção, retângulos e diagonais preenchidos por variados tons de azul. Nesse espaço organizado por linhas horizontais, verticais e diagonais -, a estrutura é somente quebrada na parte superior e inferior com o desfiar do papel, ou por manchas brancas que cobrem as superfícies, rompendo o fluxo de linhas borradas. 
[44]

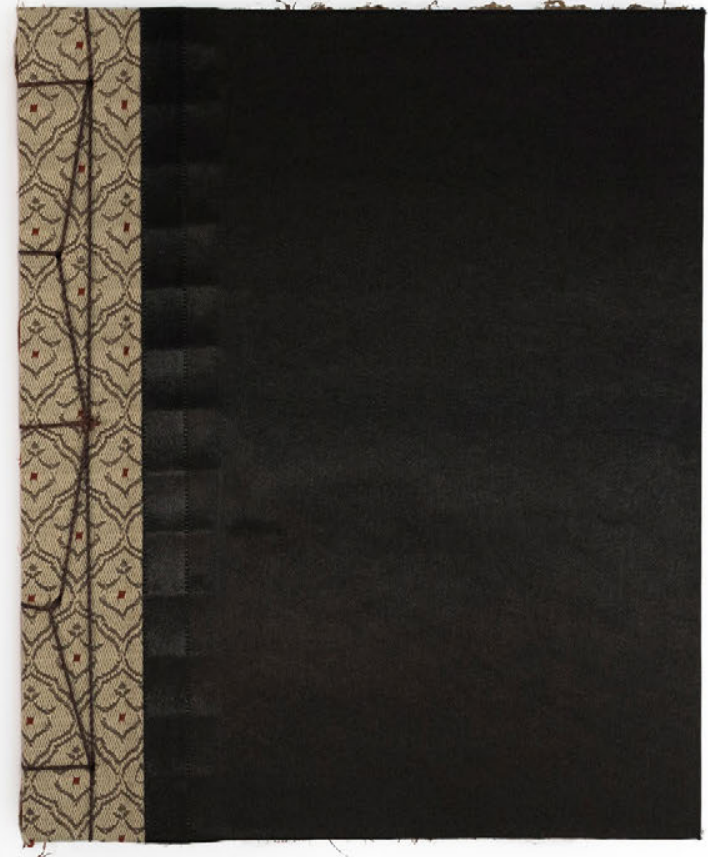

\section{CÓDICE N.3}

Técnica mista (papel de arroz, tecido, linha encerada, tinta acrílica, aquarela, nanquim, lápis de cor).

$18,2 \times 21,3 \mathrm{~cm}$ (fechado)

$31 \times 21,3 \mathrm{~cm}$ (aberto)

2016

(Ver DVD anexo) 

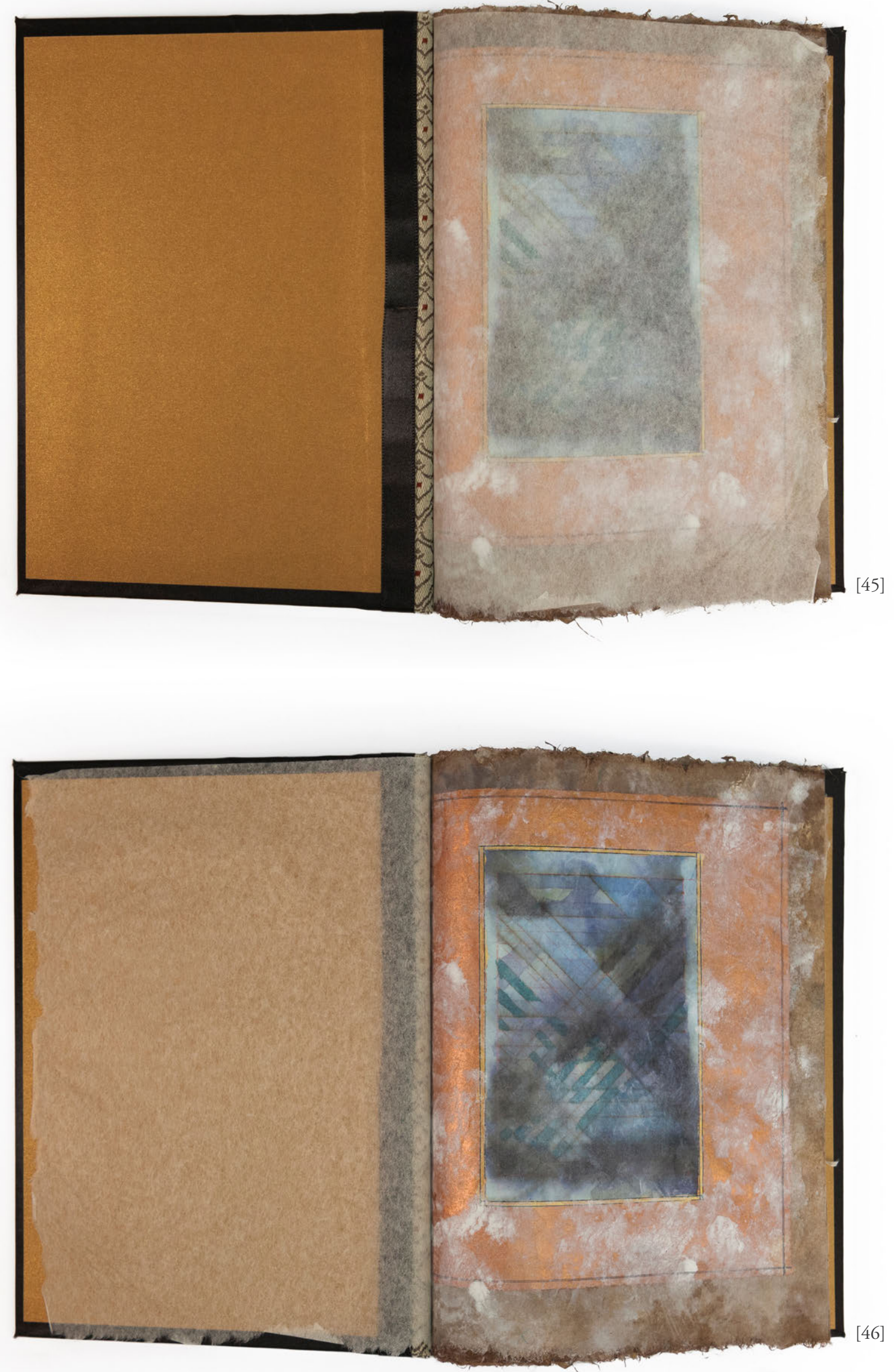

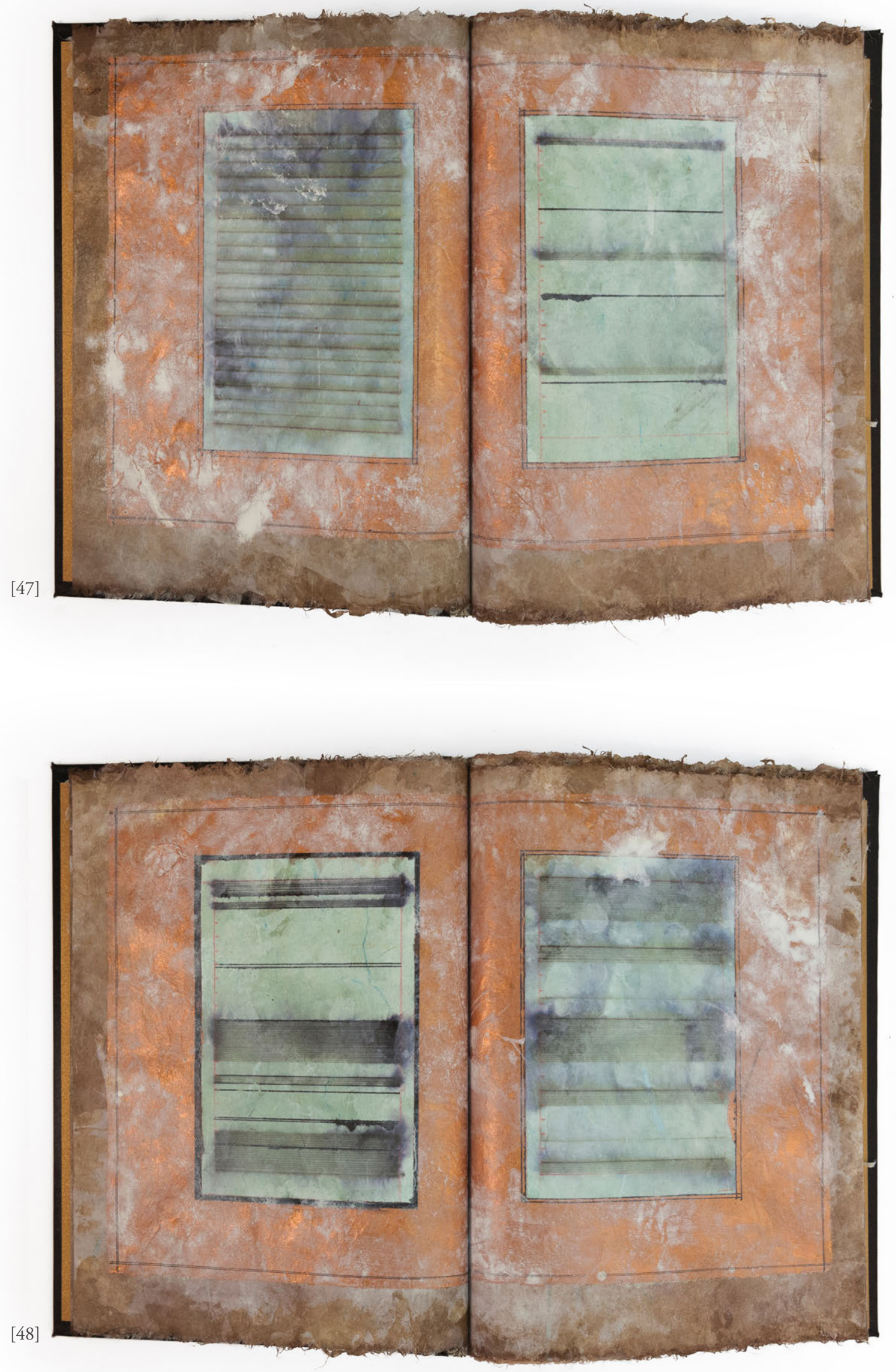


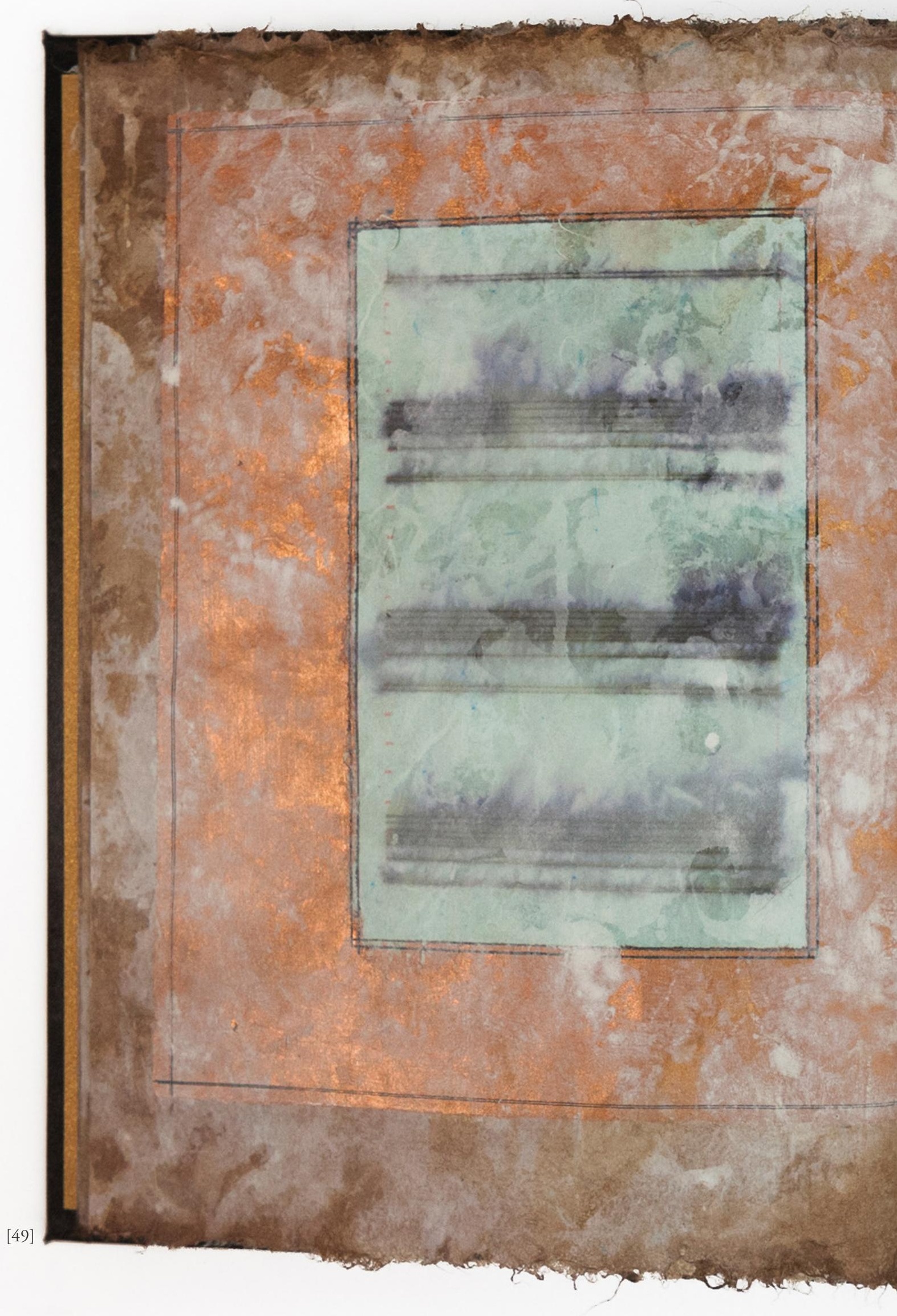




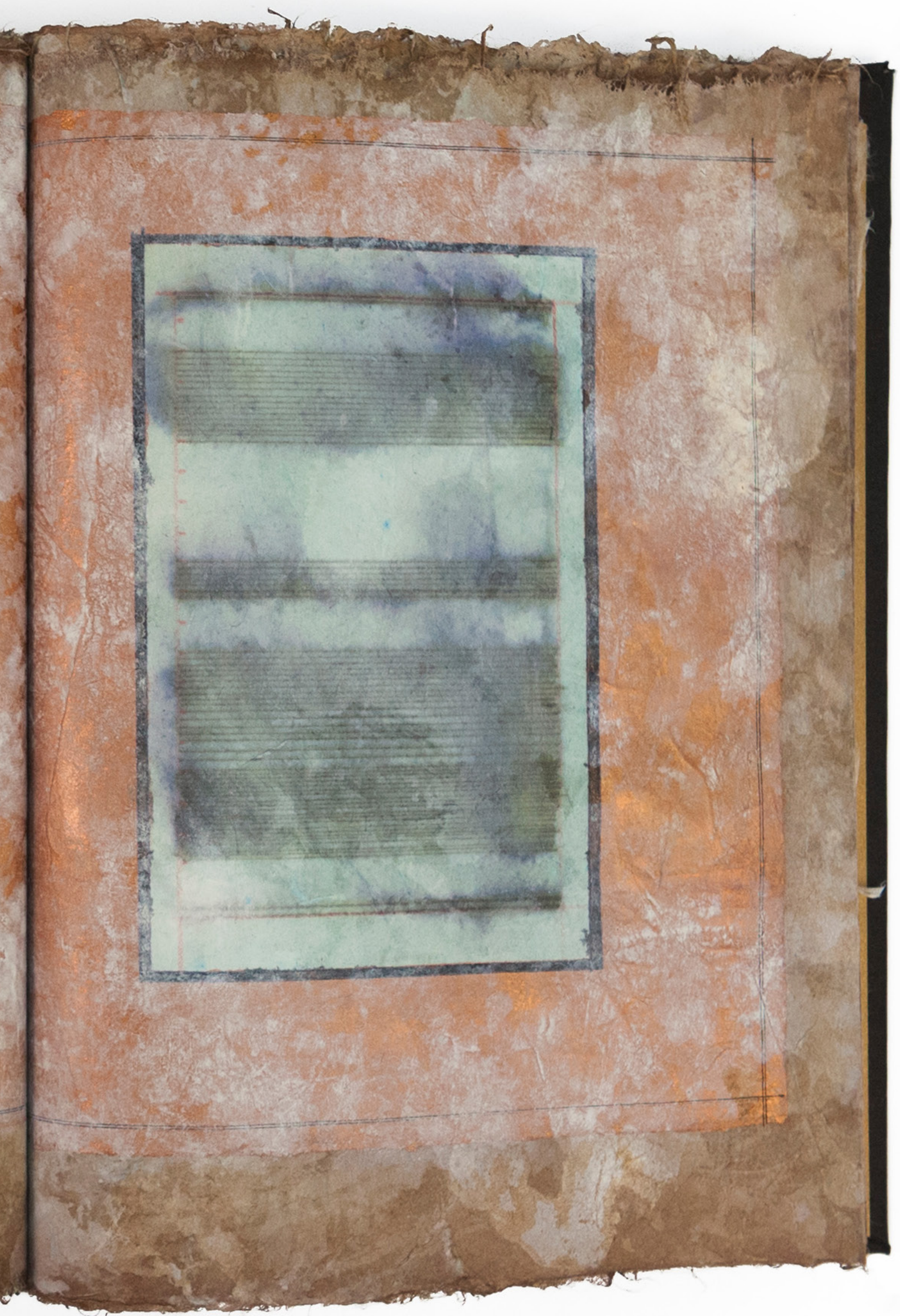



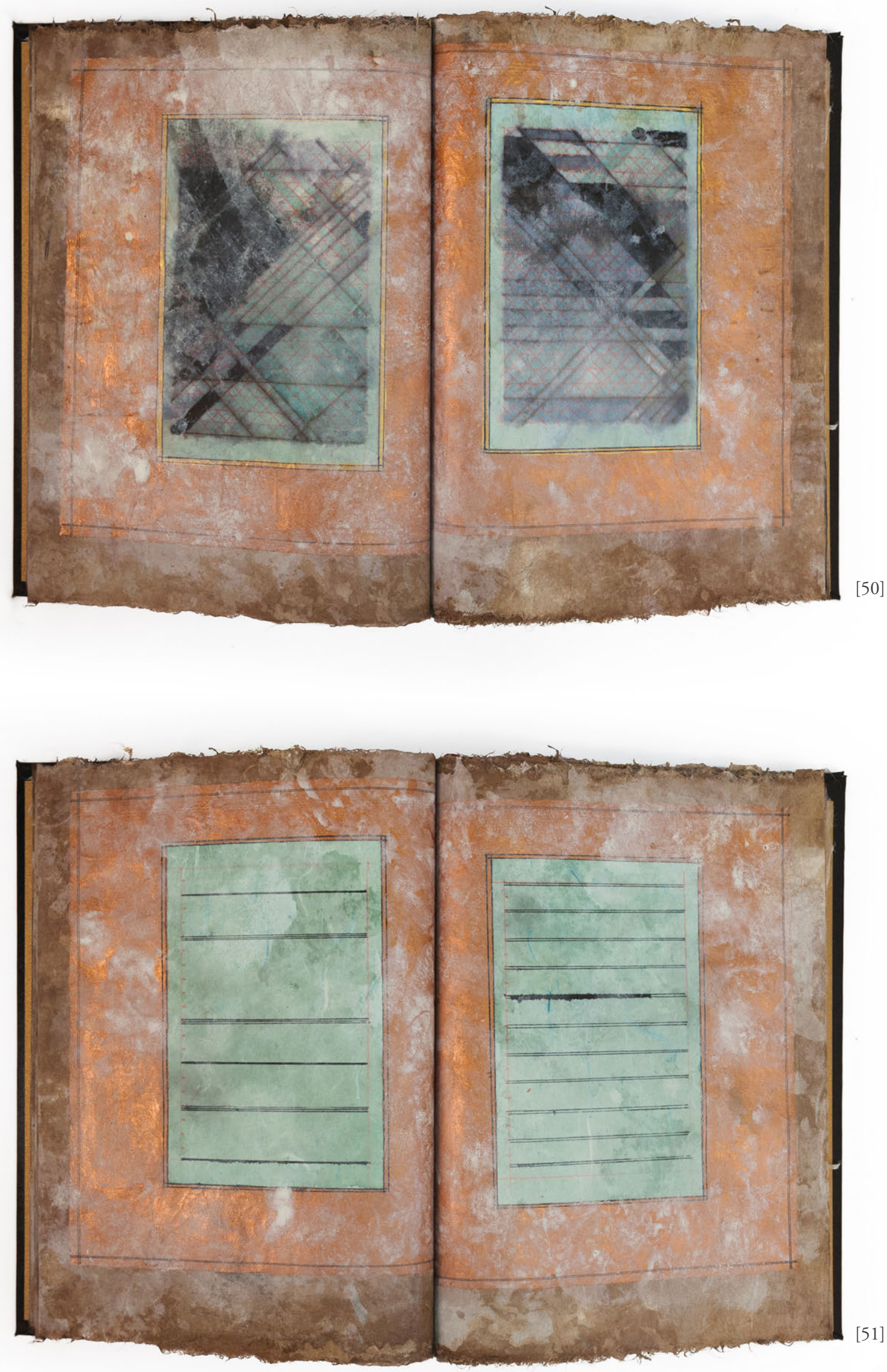

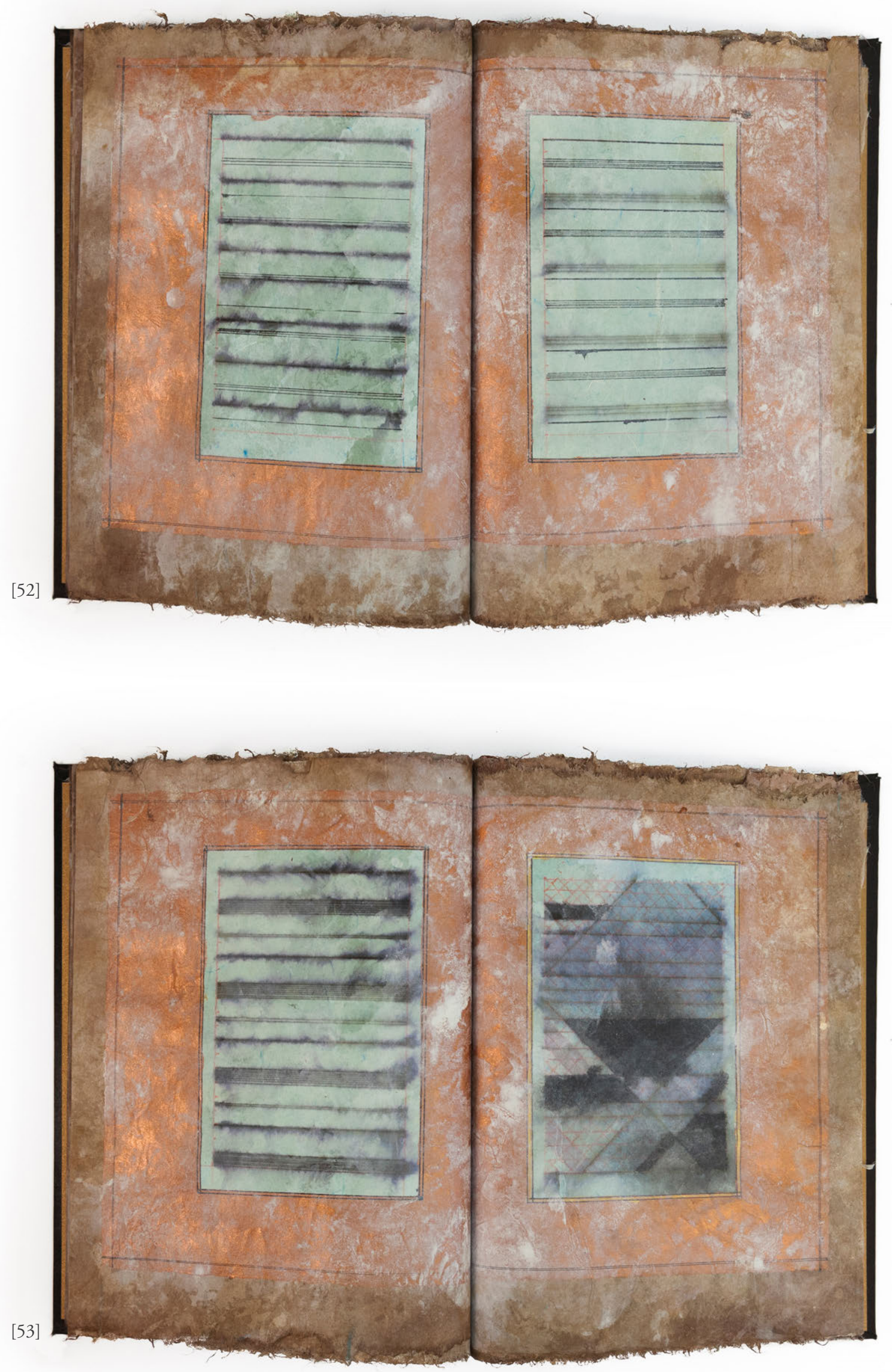


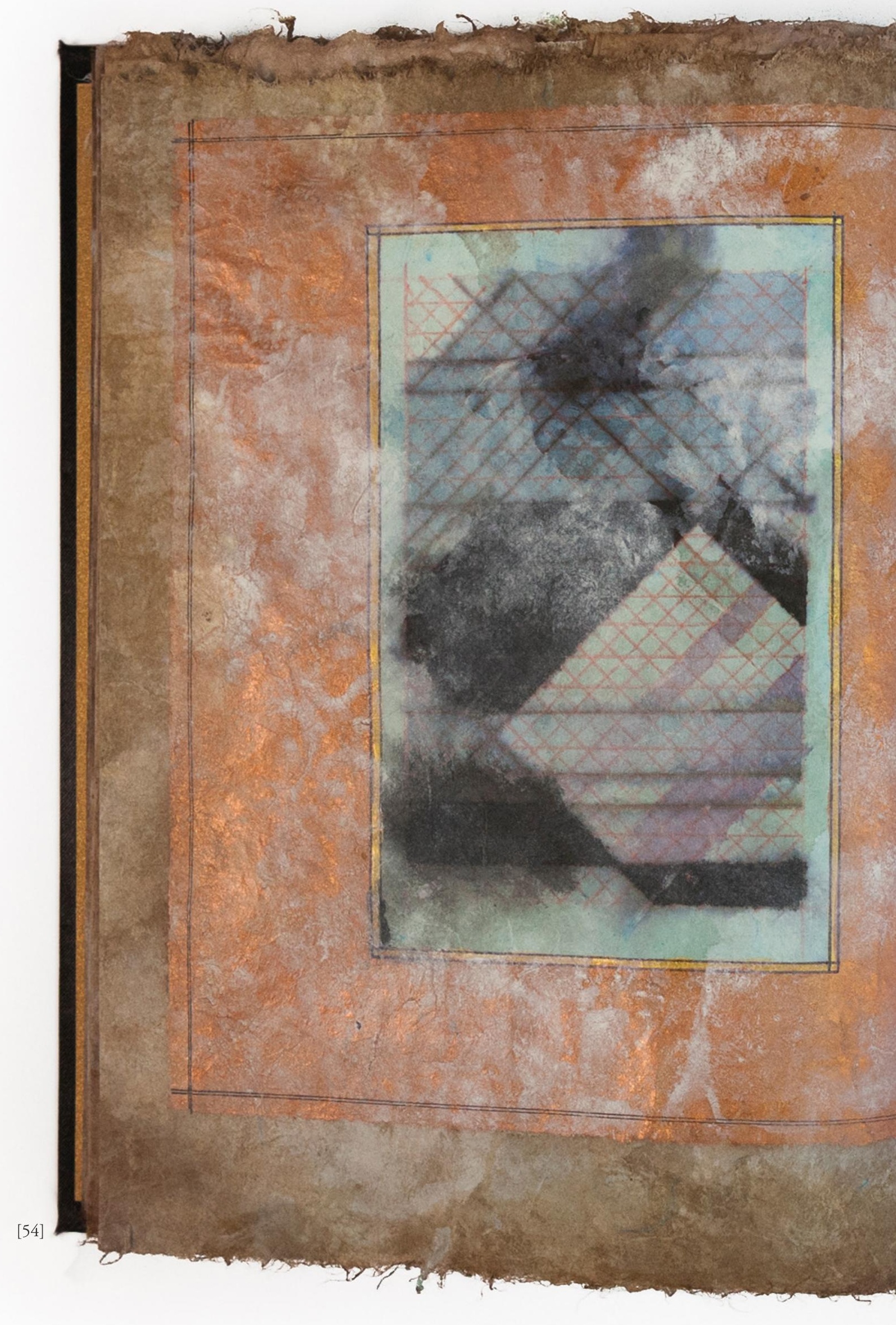




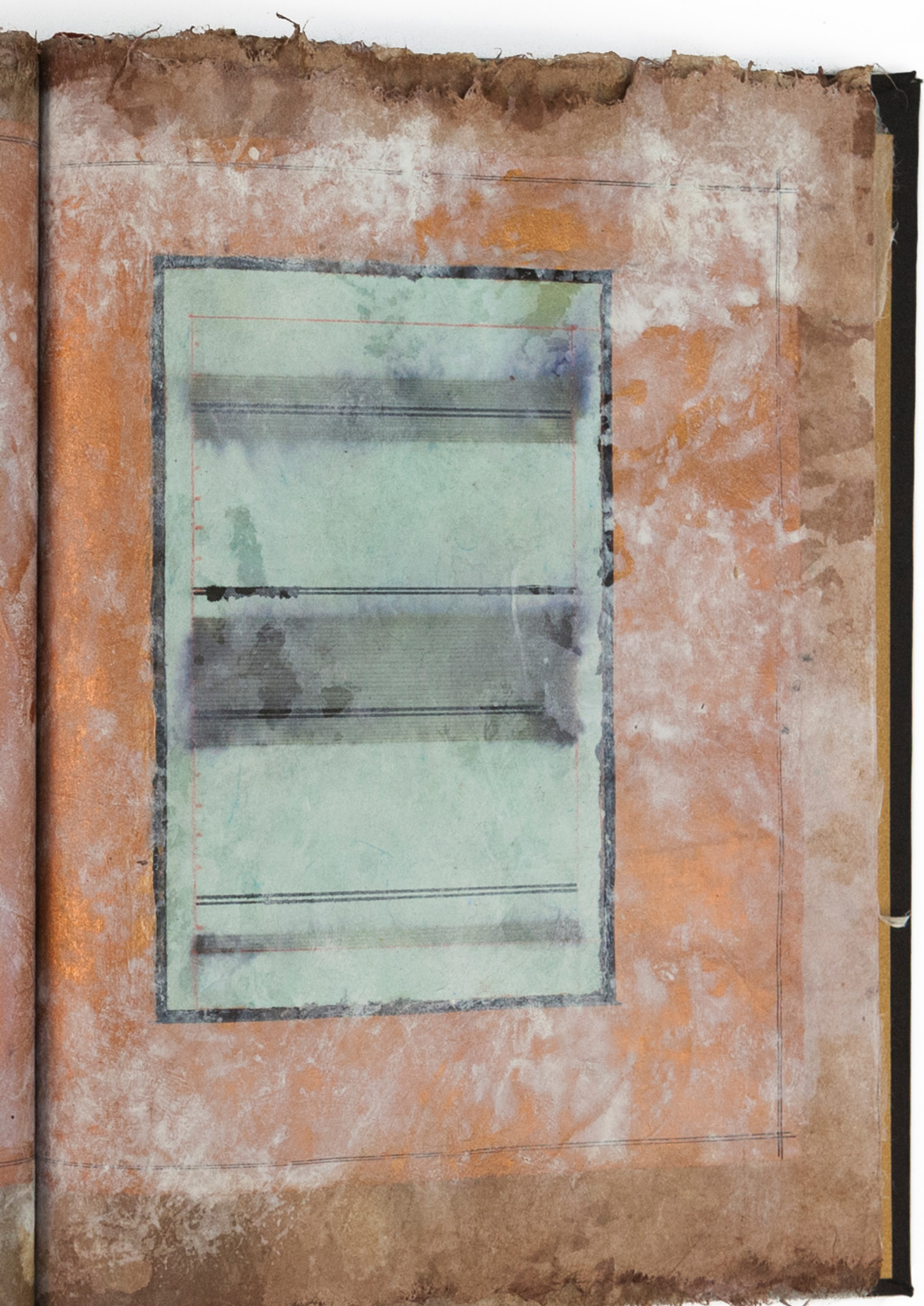




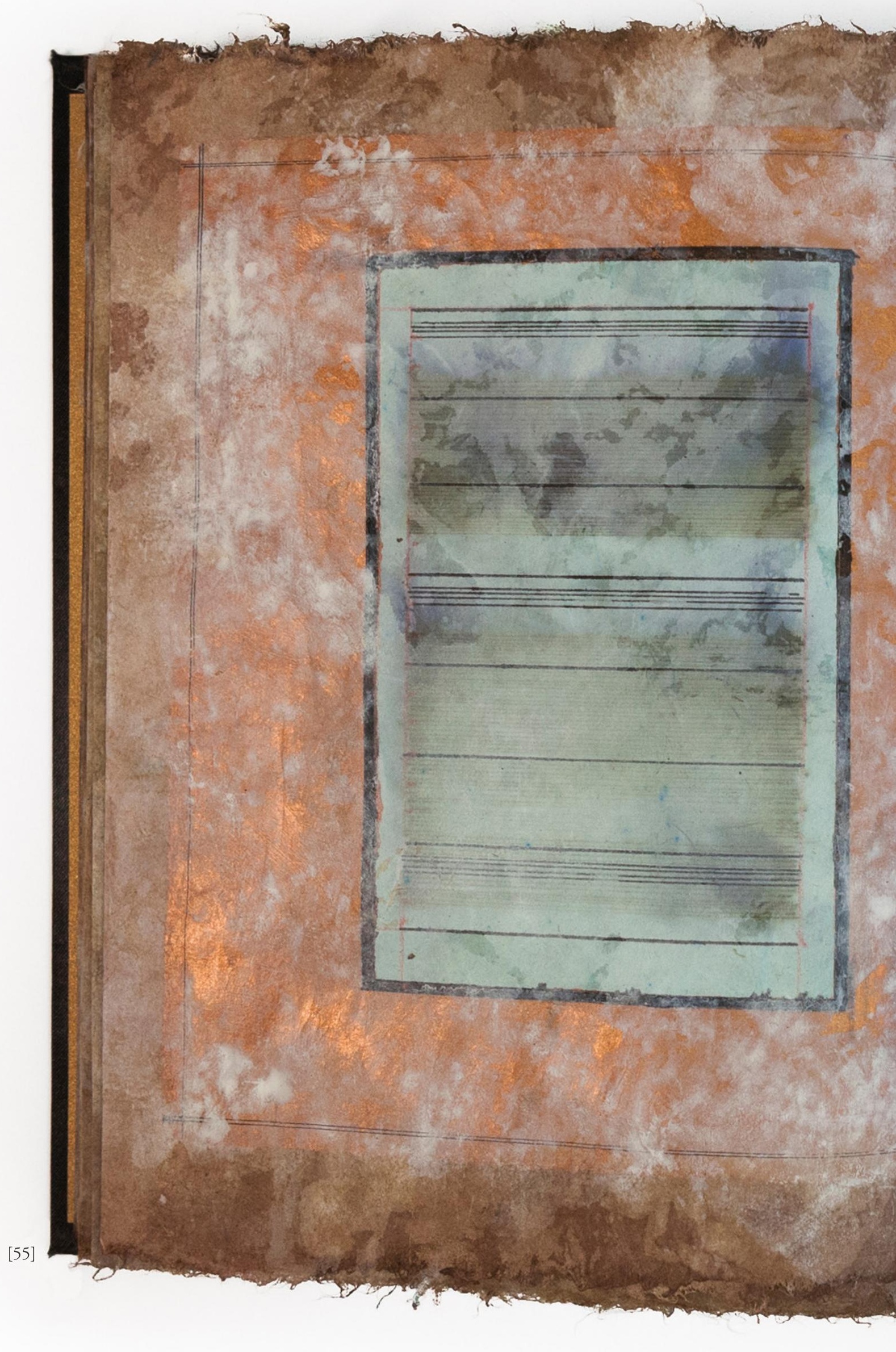




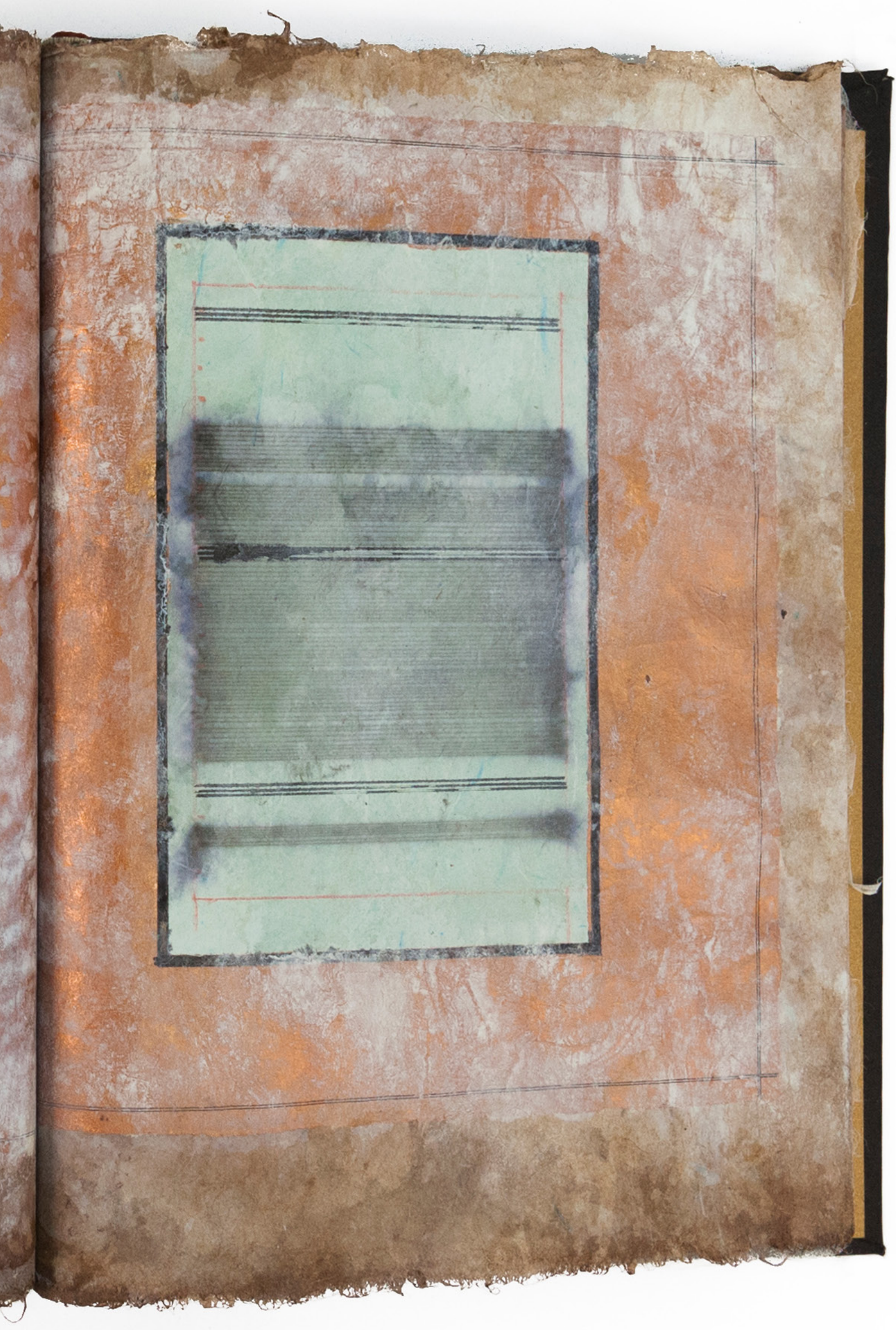



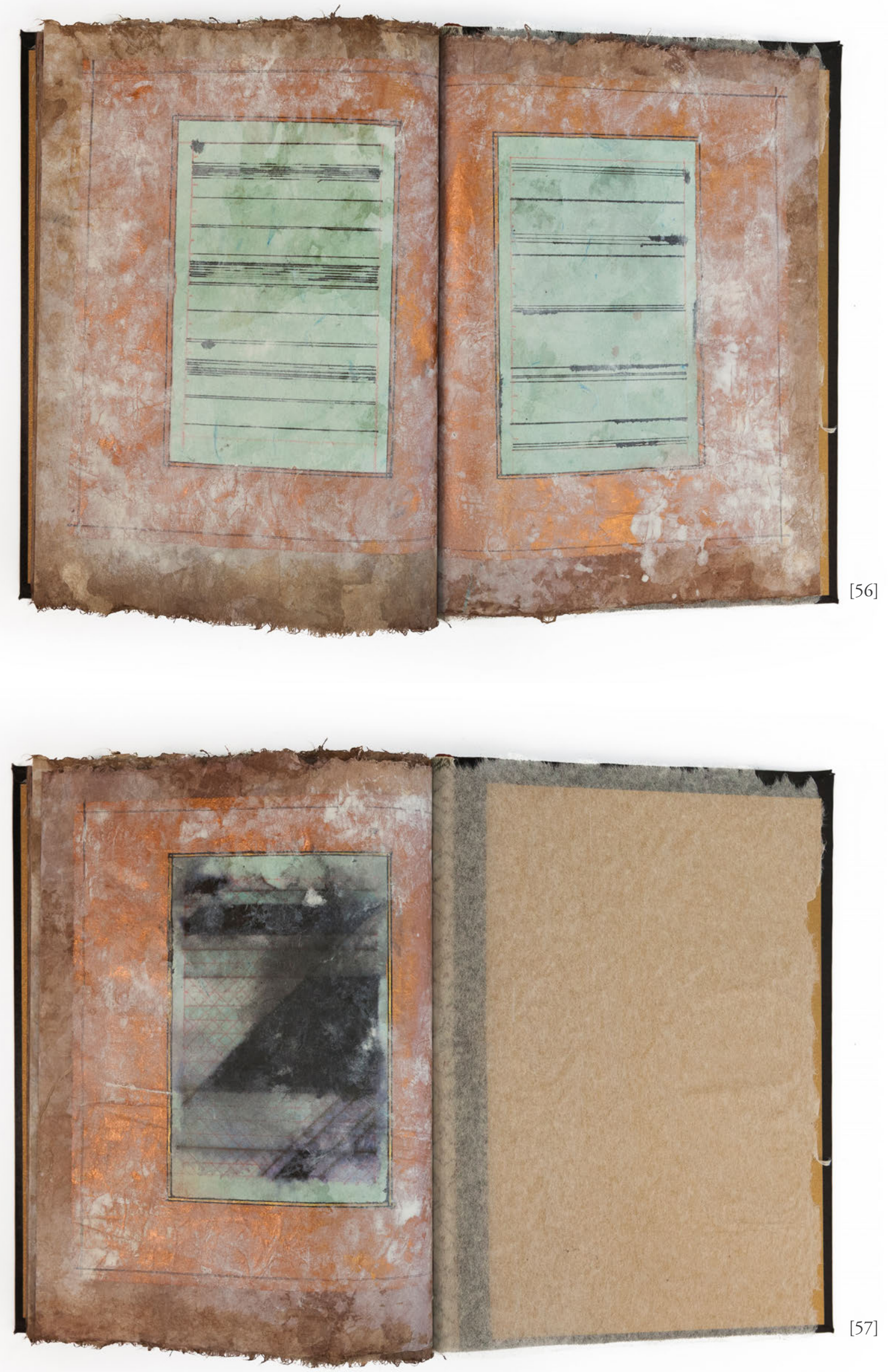

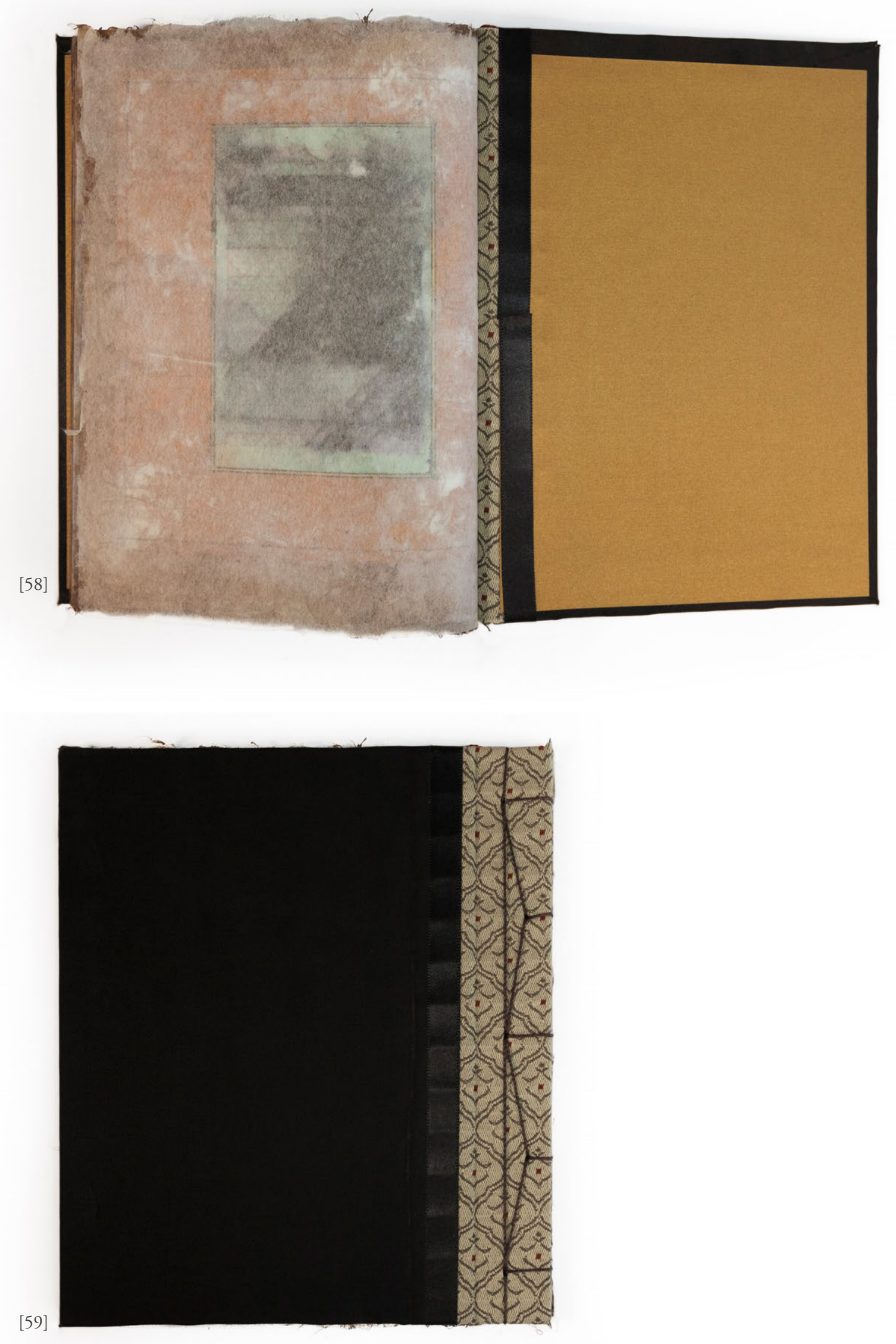

Mas naquele momento compreendi que certas modificaçôes no aspecto, na importância e na magnitude de uma criatura podem consistir na variabilidade de certos estados de espirito interpostos entre elas e nós.

Proust, Marcel. Em Busca do Tempo Perdido : À sombra das raparigas em flor, 973. 





\section{CÓDICE N.4}

$\begin{array}{ll}\text { On a bare branch } & \text { kareeda ni } \\ \text { A crow settled down } & \text { karasu no tomari keri } \\ \text { Autumn evening }^{34} & \text { aki no kure }\end{array}$

No quarto códice surge uma nova perspectiva em relação ao tempo suspenso, a partir da relação com o conceito japonês do wabi-sabi. No livro Wabi-Sabi: For Artists, Designers, Poets \& Philosophers, Koren ${ }^{35}$ aborda como, de certa maneira, esse termo pode ser considerado o "zen das coisas". Ele materializa conceitos e ideologias zen-budistas, como o fato de ambos valorizarem a experiência sensitiva do indivíduo para a transcendência do conhecimento comum em relaçáo à existência; perspectiva semelhante ao tradicional ensinamento "aquele que sabe não fala; aquele que fala não sabe". Nele se evidencia o ceticismo em relação

34 "Em um ramo nu / Um corvo se instalou / Noite de outono" Matsuo Basho, Basho : The complete haiku (Nova York, Estados Unidos da América: Kodansha USA, 2013), nossa tradução.

${ }^{35}$ Sobre a relaçáo do wabi-sabi com o zen-budismo e a buscas do conhecimento a partir da experiência, ver Leonard Koren, Wabi-sabi for artists, designers, poets \& philosophers (Estados Unidos da América: Imperfect Publishing, 2008), 16, 76. 
à ideia de as palavras darem conta do conhecimento, podendo este apenas ser alcançado por meio da experiência individual.

Nesse contexto, até mesmo um monge zen-budista, entrevistado durante um documentário da BBC Britânica - presumidamente uma pessoa familiarizada com o zen e, consequentemente, com o wabi-sabi-, vê entraves e é relutante em explicar verbalmente o significado a um estrangeiro que não está imerso na cultura nipônica.

Put simple, there is no definition for Wabi-Sabi. If it could be defined, it wouldn't be Wabi-Sabi. (...) The monks reluct to define wabi-sabi. Is an expression of very buddhist notion, the language is inadequade when come to try to understand the world. What he is saying is in a sense I need to stop looking a wabi-sabi definition and let myself be open, instead, to wabi-sabi feelings. ${ }^{36}$

Dentre diversas influências, em especial do cinema oriental, encontro a leveza do tempo no filme Primavera, Verão, Outono, Inverno... e Verão. ${ }^{37}$ Há nele uma indicação de solução estética e metódica para adentrar a linguagem do wabi-sabi. Durante uma longa cena, um monge, aparentemente em processo meditativo, escreve sobre uma telha com o pincel embebido em água. Ao

\footnotetext{
${ }^{36}$ De maneira simples, não há definição para Wabi-Sabi. Se ele pudesse ser definido, ele não seria Wabi-Sabi (...) Os monges são relutantes em definir o Wabi-sabi. É uma expressão de conceito profundamente budista, a linguagem é inadequada quando se deseja compreender o mundo. O que ele está dizendo é que eu preciso parar de procurar pela definição do Wabi-sabi e, ao invés disso, me deixar aberto para os sentimentos do Wabi-sabi." BBC, "In Search of Wabi Sabi with Marcel Theroux", YouTube, janeiro de 2016, https://www. youtube.com/watch?v=Z2P8z7kYJW0.

${ }^{37}$ Kim Ki-duk, Primavera, Verão, Outono, Inverno... e Verão, NTSC, colorido, Longametragem (California Filmes, 2003).
} 

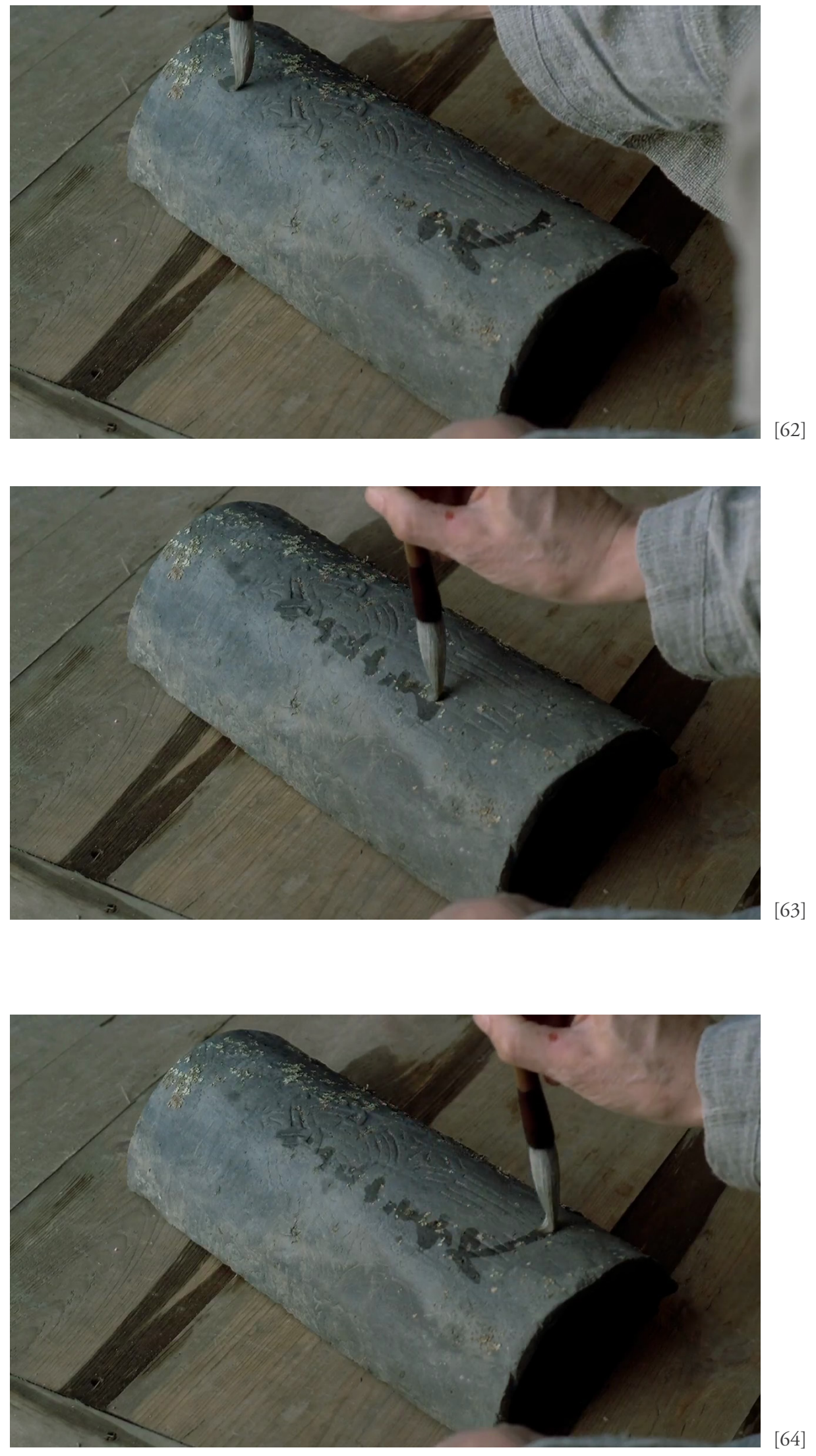
terminar a escrita em sentido vertical, as primeiras pinceladas já secaram e desapareceram, o que dá espaço para a escrita recomeçar incessantemente, pois sempre ao chegar à base, a parte de cima já secou e desapareceu. Nesse processo, o texto escrito é apenas um meio para alcançar o verdadeiro objetivo do monge. Koren comenta esse processo:

Nonthinking repetition of mechanical forms allows one to concentrate simply on being without the distraction of having to make decisions, artistic or otherwise. ${ }^{38}$

E complementa em nota de rodapé:

Another aspect of this practice is the belief, from Zen, that the body, not language, is the repository of knowledge and technique. Hence tea focuses on the rote learning of forms. ${ }^{39}$

O filme sugere um novo método para a fatura do livro. Nele, inicialmente planejo todos os elementos envolvidos no processo de trabalho- o tipo de papel (arroz), tintas (ecoline amarelo, azul, vermelho, nanquim e tinta acrílica branca), composiçáo, tipo e quantidade de pinceladas a serem dadas. Desse modo, durante a pintura, a concentraçáo pode se voltar apenas para o movimento das sucessivas pinceladas curtas, sempre do mesmo tamanho e com igual distanciamento entre si. A cada folha, são decididas a ordem e frequência

\footnotetext{
38 “Ao repetir movimentos mecânicos sem pensar permite se concentrar simplesmente em ser sem a distração de precisar fazer decisóes, artísticas ou de qualquer tipo" Koren, Wabi-sabi for artists, designers, poets \& philosophers, 35, nossa tradução.

39 “Outro aspecto dessa prática é a crença, originária no Zen, em que corpo, e não a linguagem, é o repositório da técnica e do conhecimento. Dai o chá focar na prática rotineira das formas." Koren, Wabi-sabi for artists, designers, poets \& philosophers, 81, nossa tradução.
} 
para as cores serem aplicadas no grid de quadrados, sendo apenas imprevisível a pintura formada após a disposiçẫo e sobreposiçấo dos quadrados. No processo são geradas pequenas manchas borradas devido à coincidência de múltiplas cores serem aplicadas no mesmo local. Como exemplo do processo em uma suposta página, alterno entre pinceladas cheias e espaços vazios (aqui sendo a pincelada representada em negrito): amarelo na ordem de 1:4, azul em 4:3, vermelho com 1:1:1:1:9:6, preto em 7:2:5:1. Ao final, uma camada de tinta acrílica branca reveste toda a superfície de quadrados, exceto em um pequeno retângulo variando seu posicionamento a cada página.

Definindo de início todas as escolhas estéticas, restrinjo minhas possibilidades formais durante o pintar, restando apenas o movimento gerador de curtas pinceladas ao longo da folha. Por não poder compor ou trabalhar o gesto da pincelada durante a pintura, é possível, durante o trabalho, me concentrar na precisão da pincelada. Caso ela não saia precisa, noto minha distração e retomo minha concentração. Enquanto a concentração se dirige ao micro, formado pelas curtas pinceladas, também fico atento ao macro: percebendo barulhos, ruídos, movimentos, a temperatura e o peso do corpo quase durante todo o tempo da pintura. Em vez de refletir esteticamente a leveza do tempo, por meio da composição, o Códice n.4 encontra a percepção da passagem do tempo na fatura das pinturas, para dessa forma o trabalho concluído refletir essa vivência. 


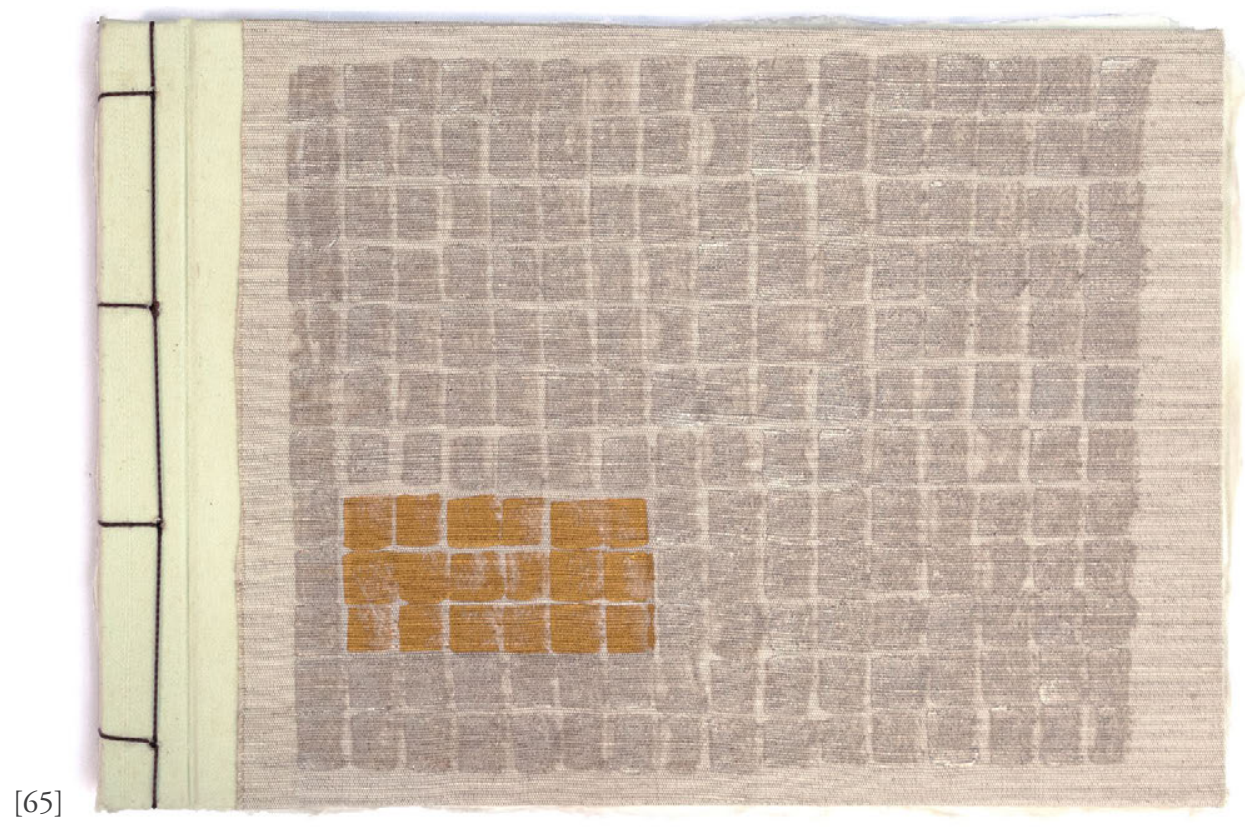

\section{CÓDICE N.4}

Técnica mista (papel de arroz, papel-manteiga,

linha encerada, ecoline, tinta acrílica, tecido).

$31,6 \times 22,4 \mathrm{~cm}$ (fechado)

$58,2 \times 22,4 \mathrm{~cm}$ (aberto)

2016

(Ver DVD anexo) 


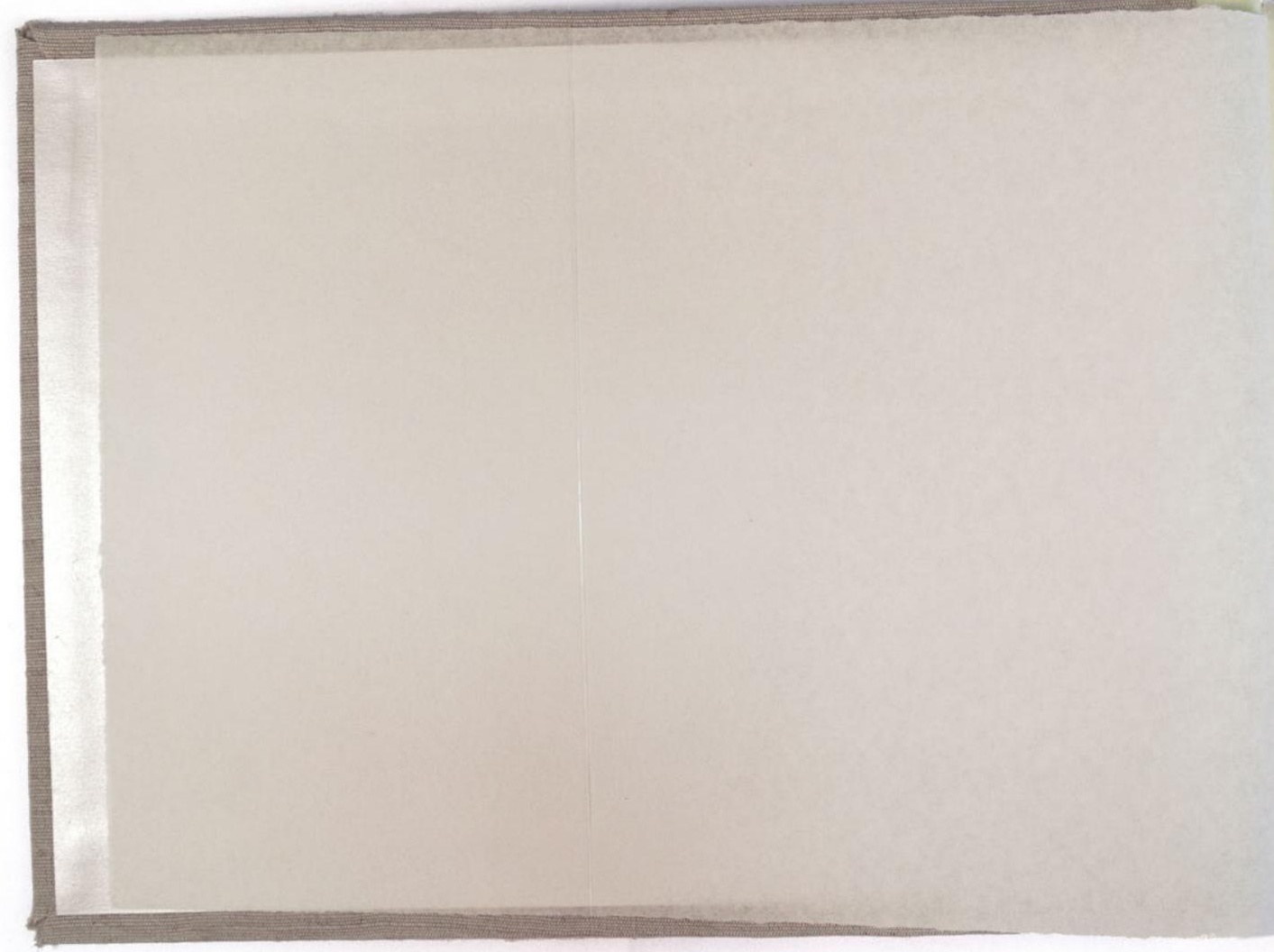

[67]

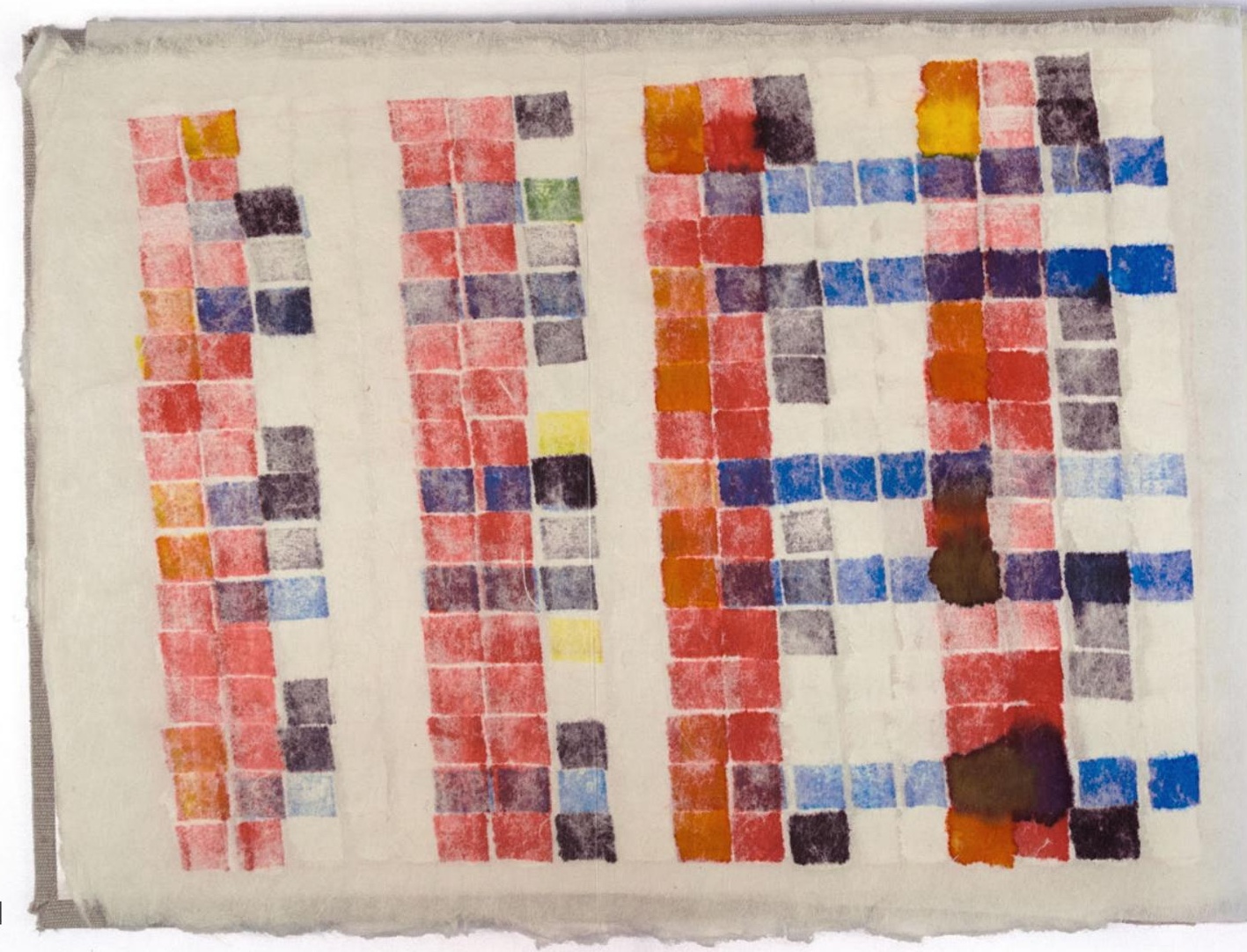


Lat? कीज1 政 binger 4 wa II ating

\section{सक्षय 11 $1 / 31$} Q 1) 1 b: $=2$ E) i i का का 1 iा 1 141111 का 1 (3) i) 4 [i] 111 $\begin{array}{lll}1 & 1 \\ 1 & 1 \\ 1 & 1 \\ 1 & 1\end{array}$ 143 1 11 ? a. i.

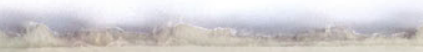

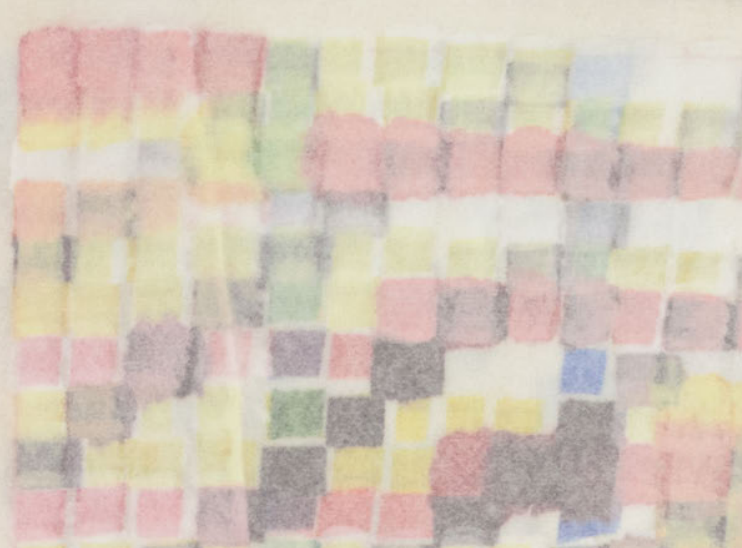



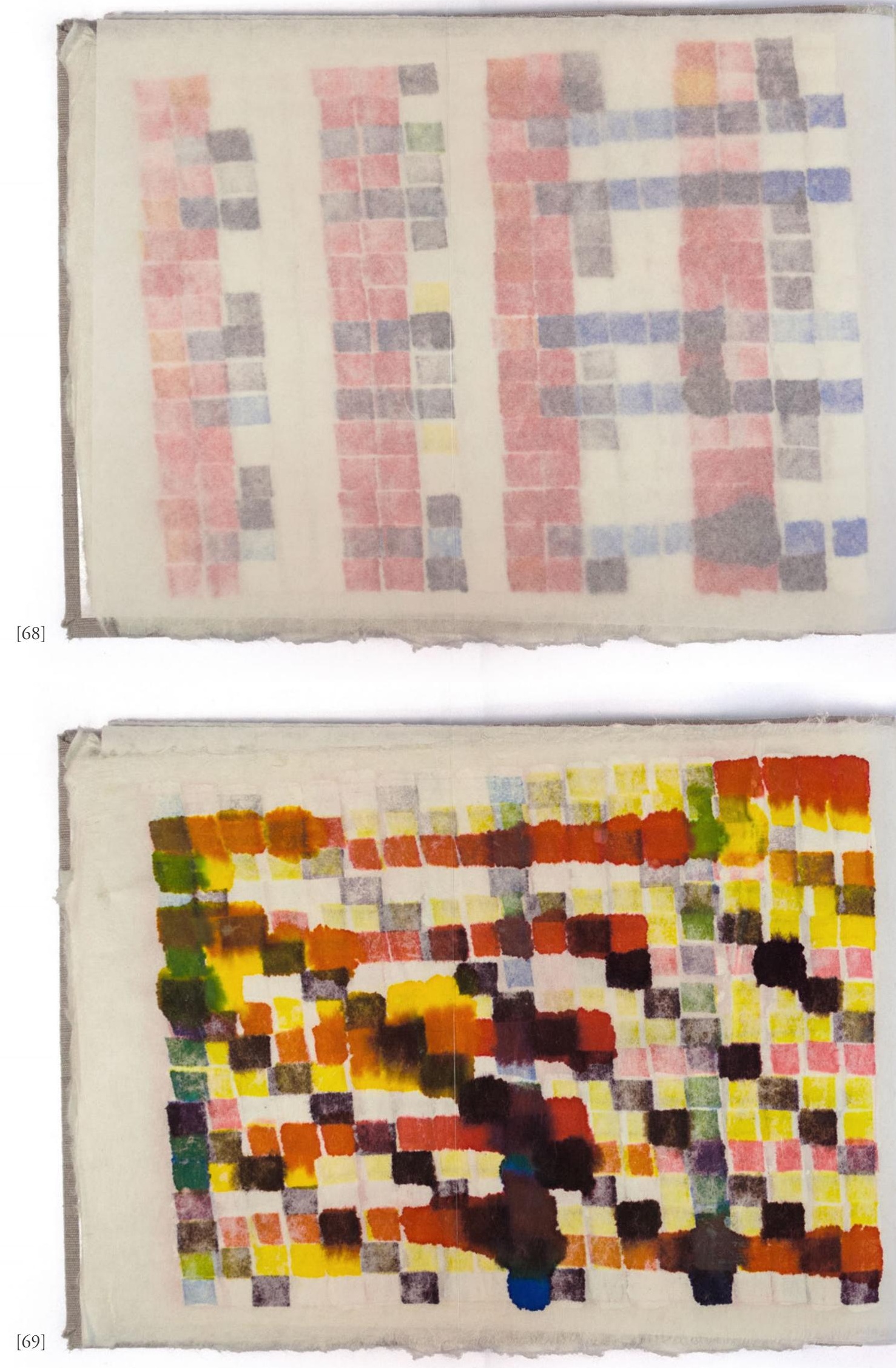


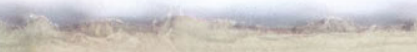

97.17

(1) म्न

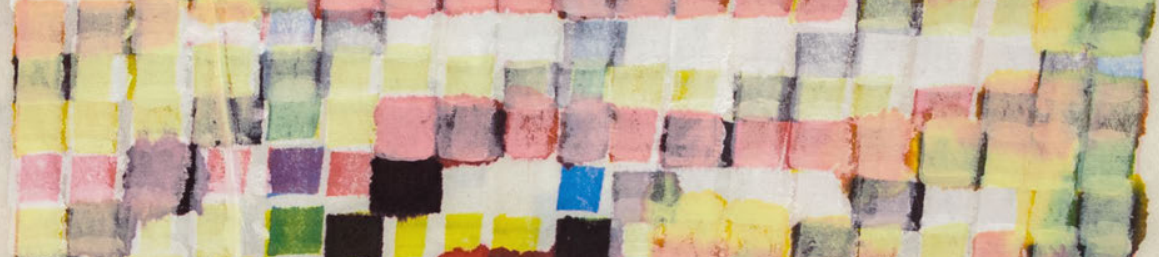

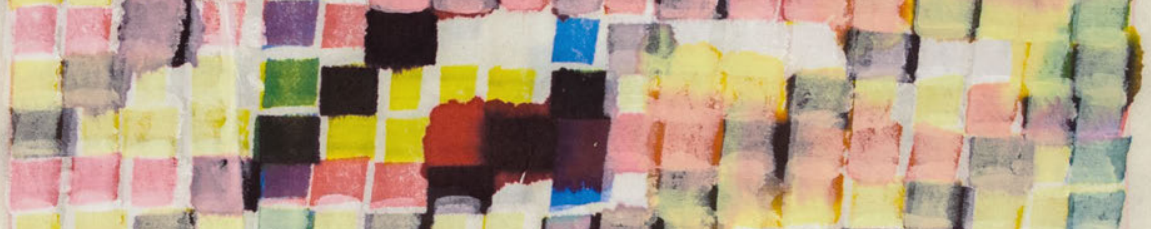

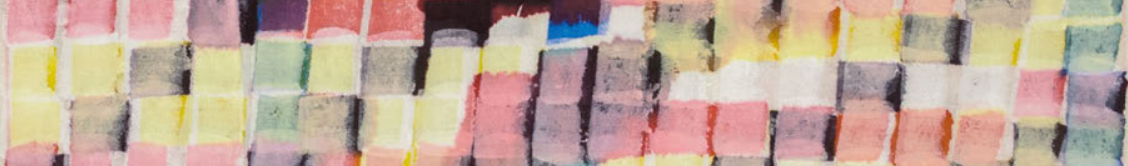

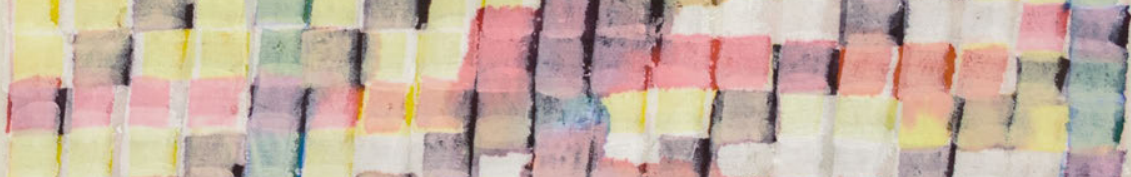

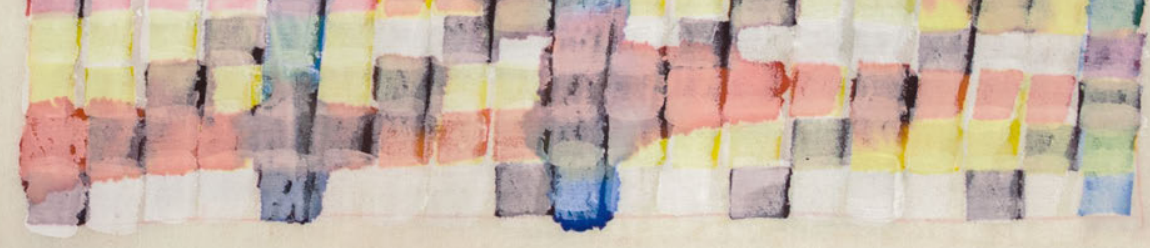

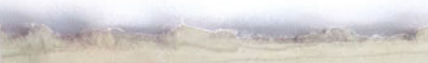

(1) 10

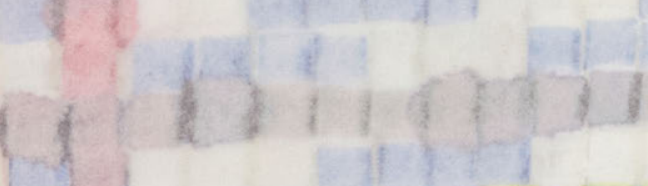



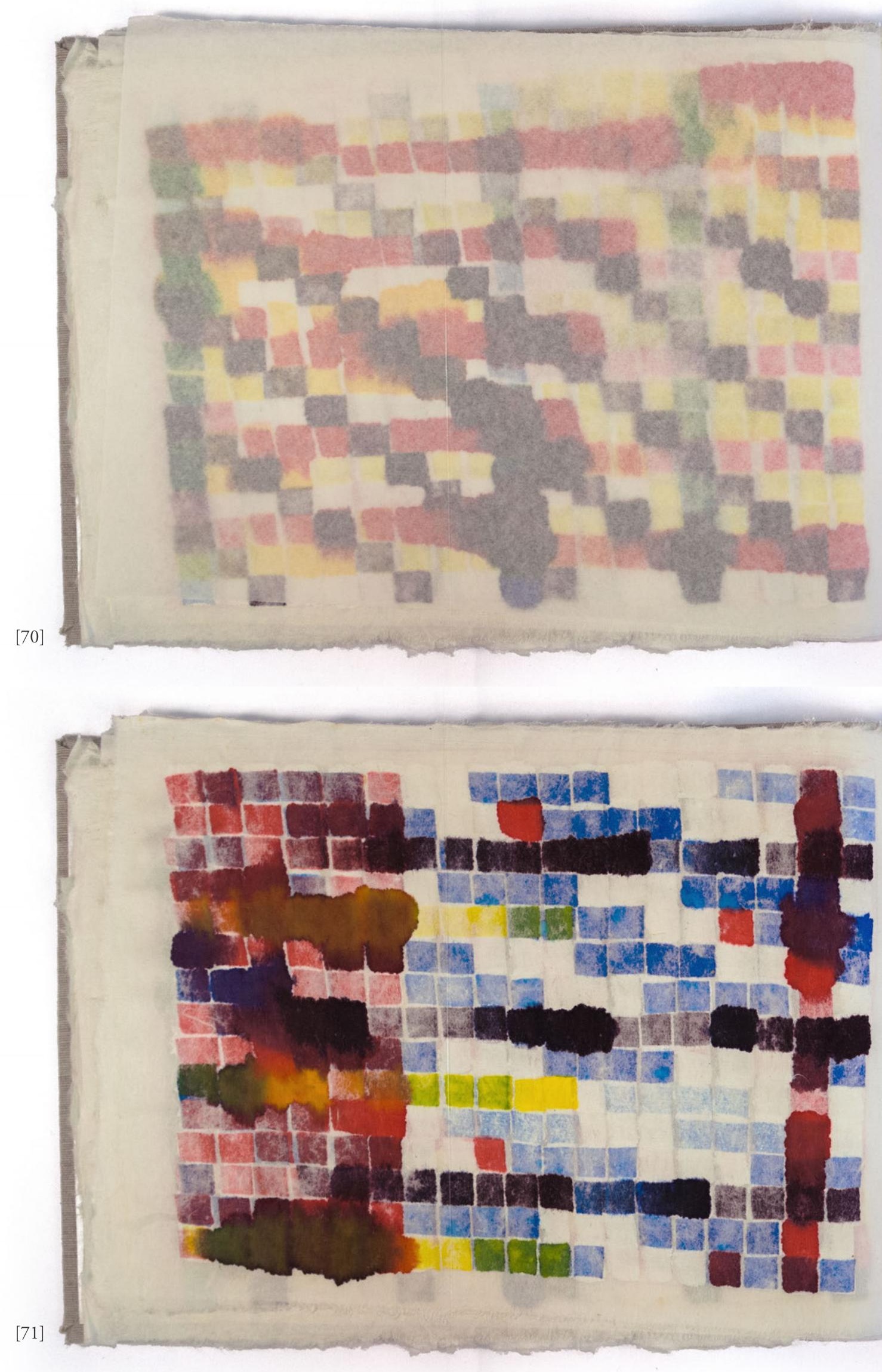


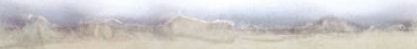
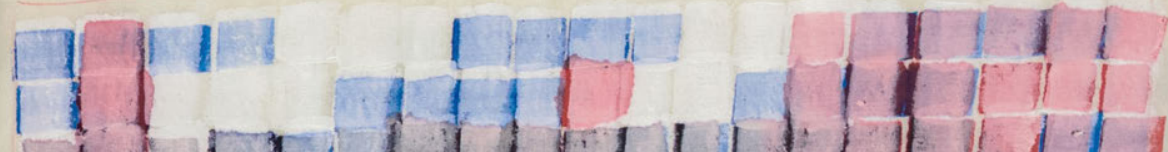

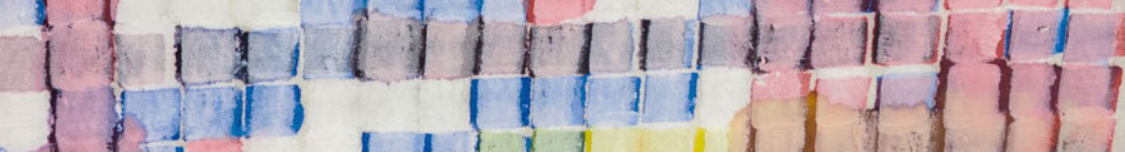

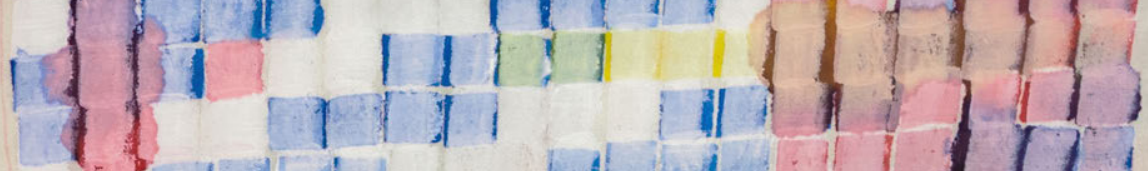

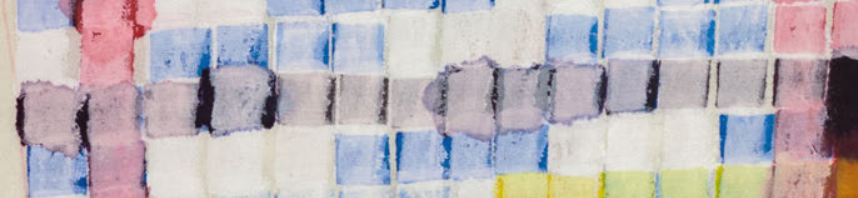

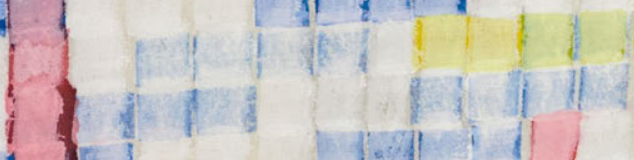

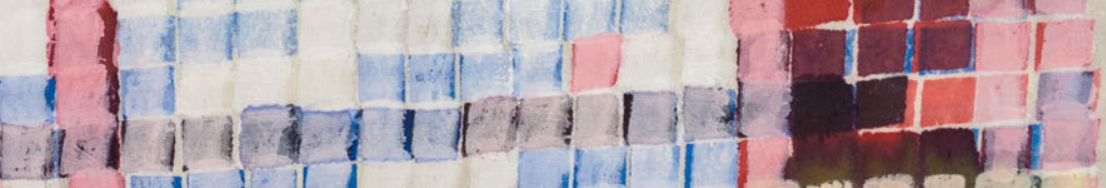

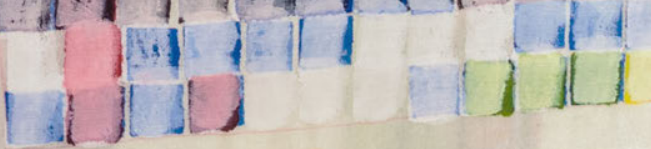
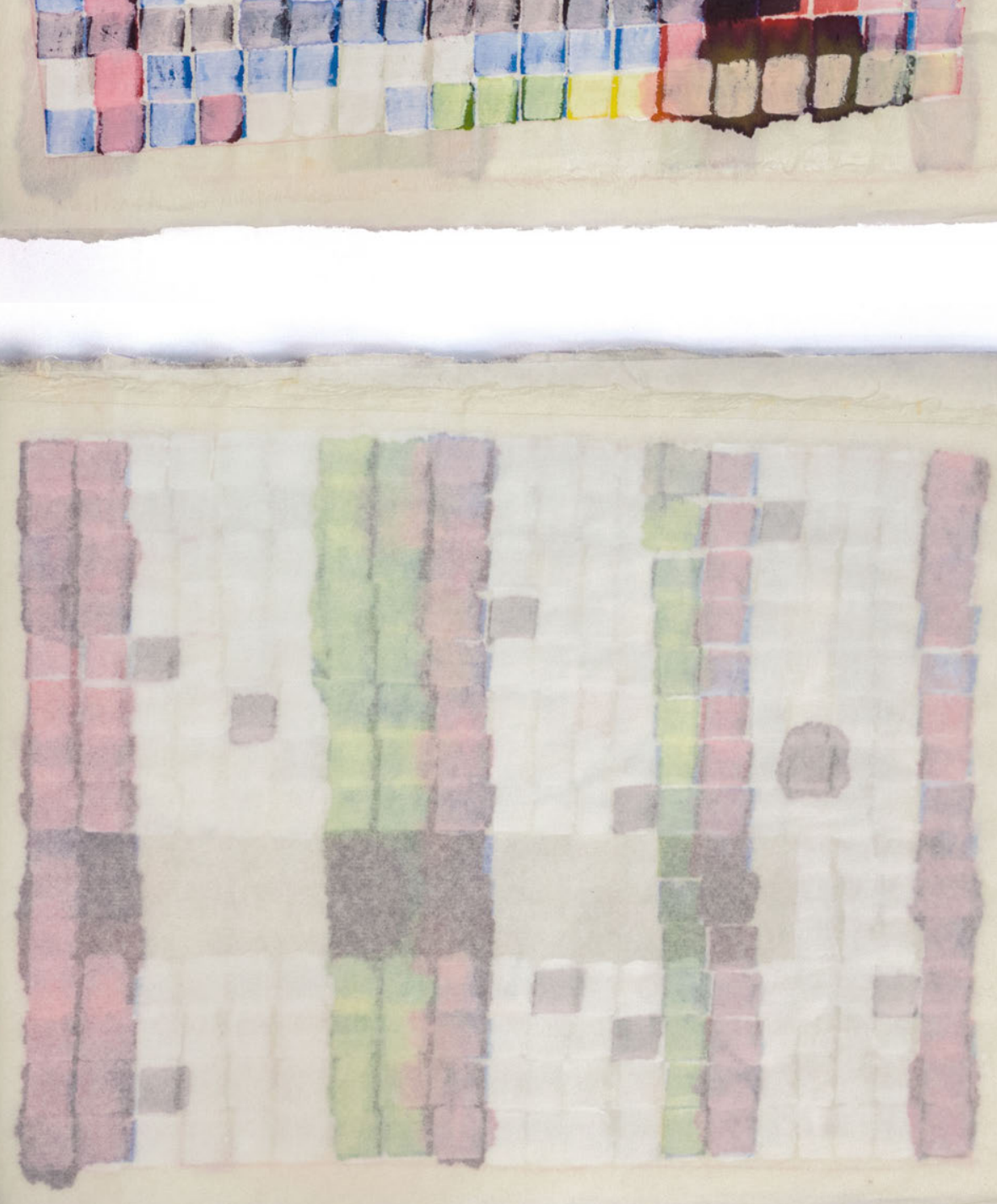

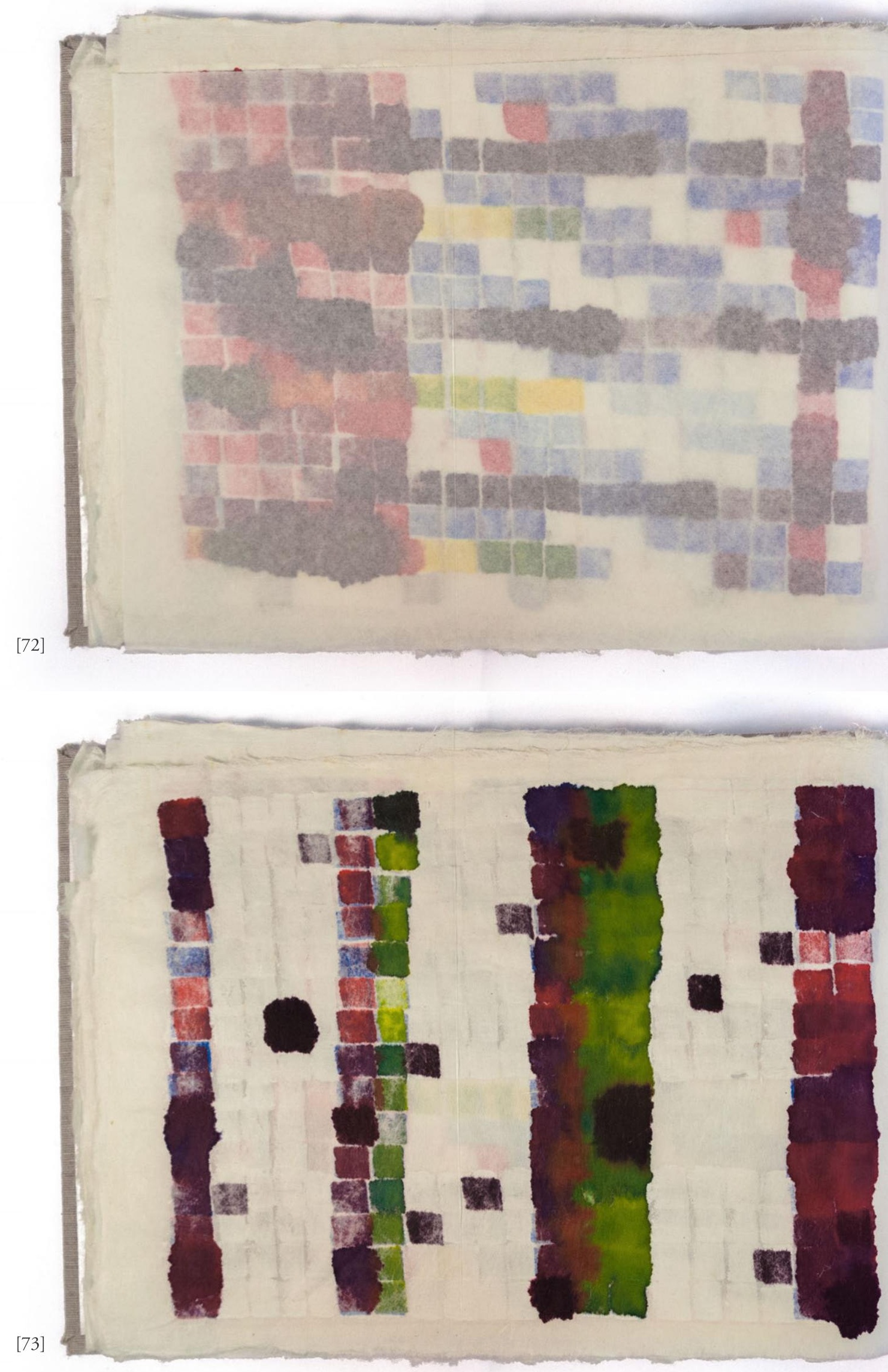

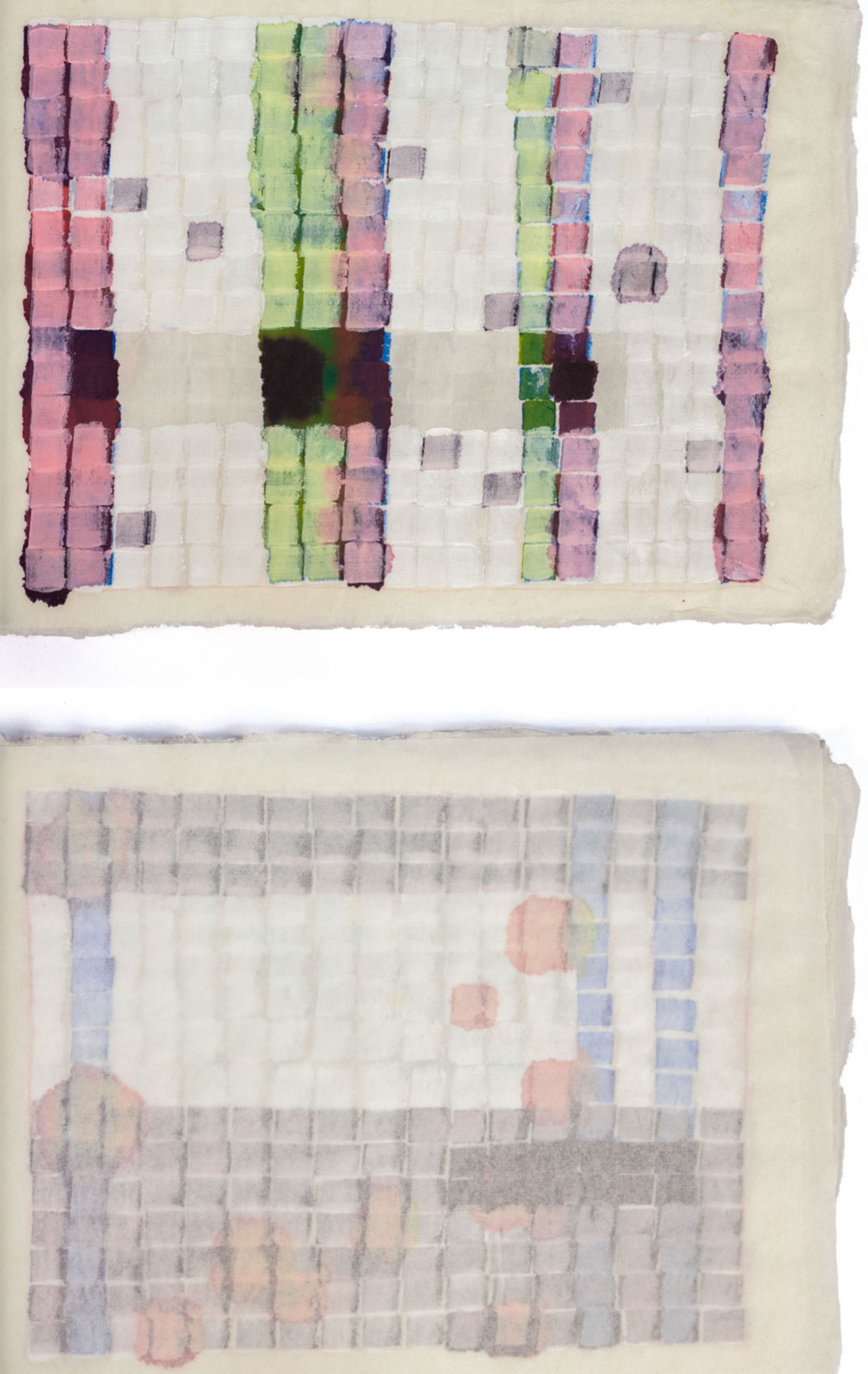

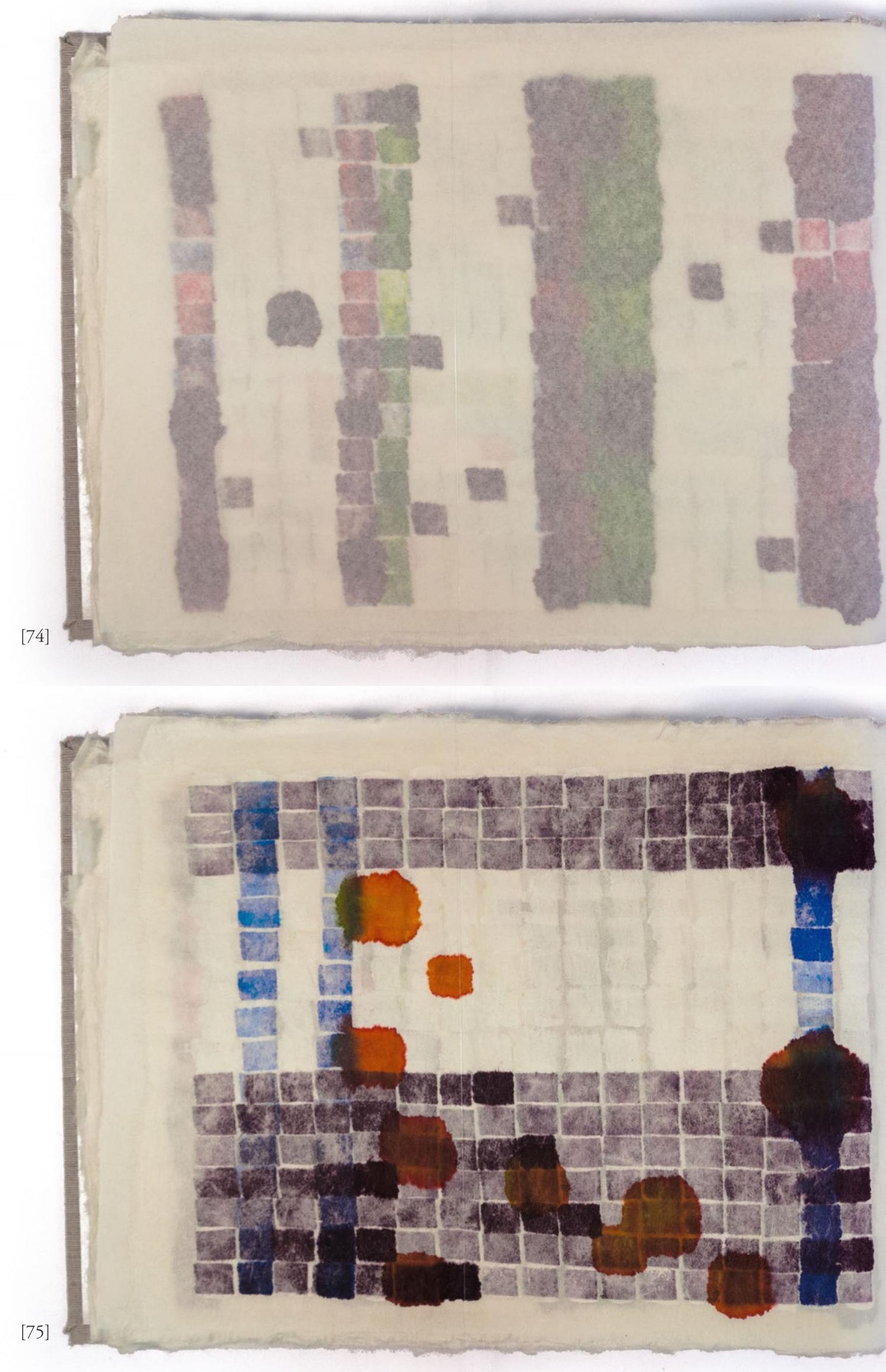


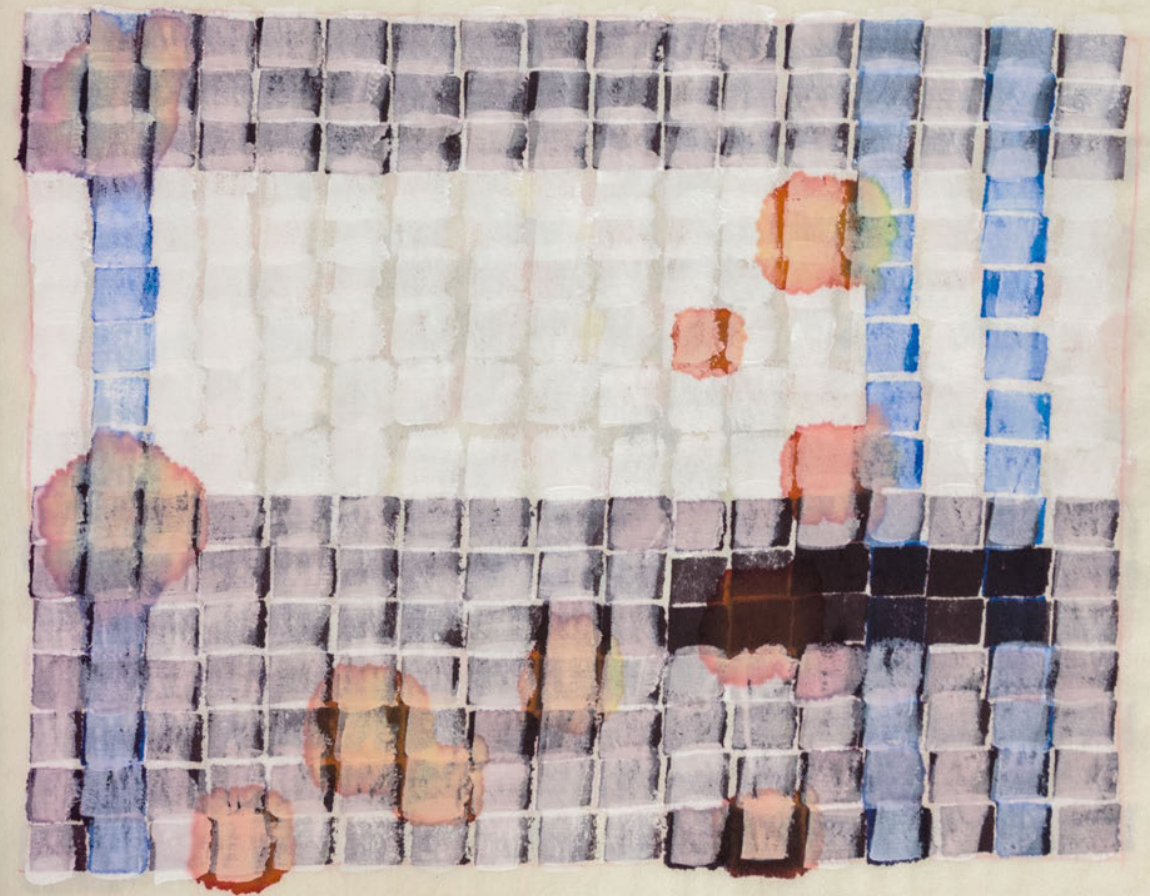



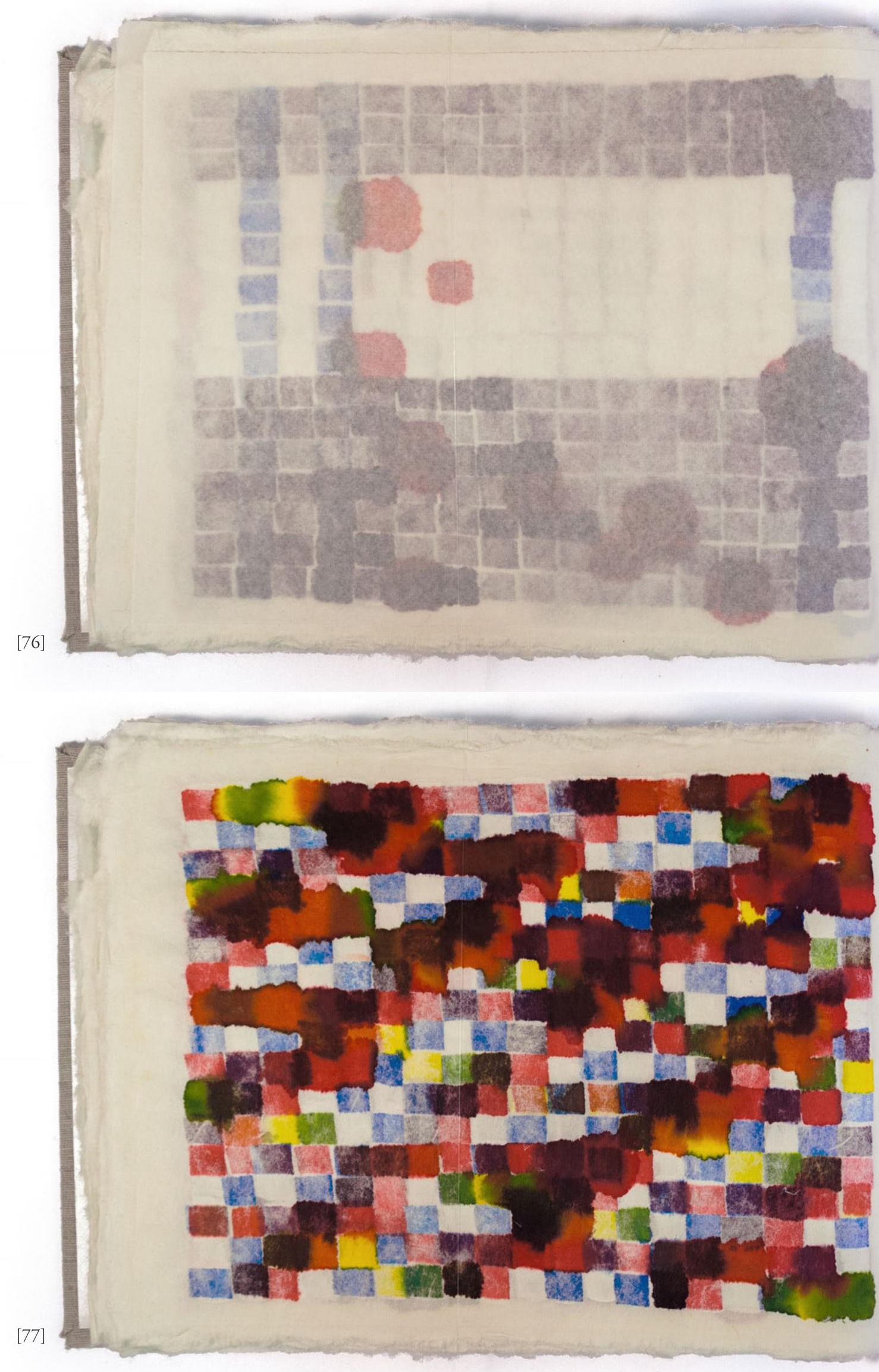


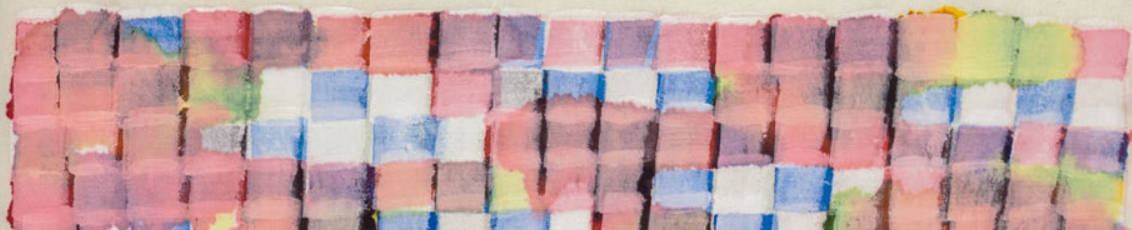

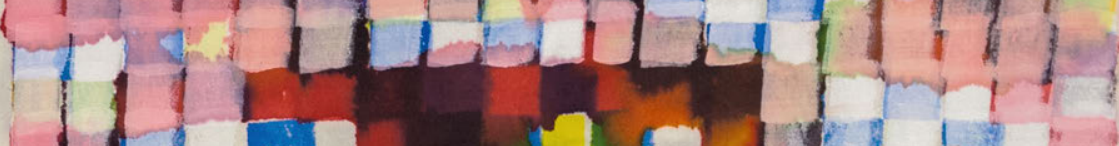
$14\left(\begin{array}{ll}1 \\ 1\end{array}\right.$

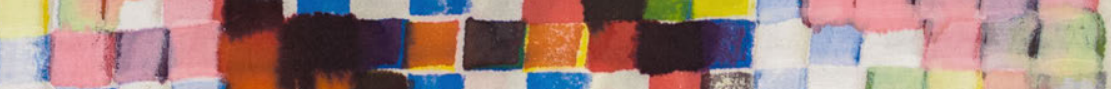

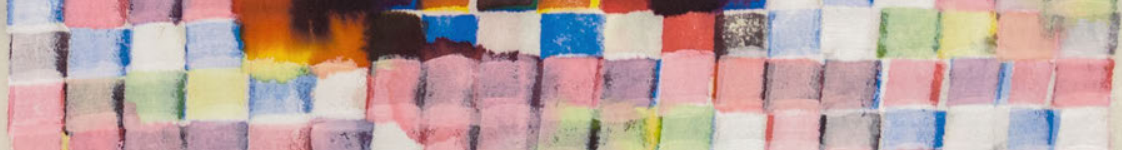

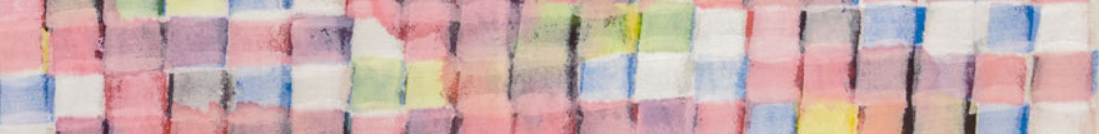

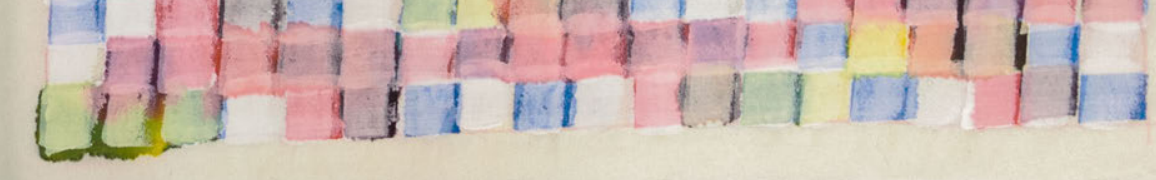

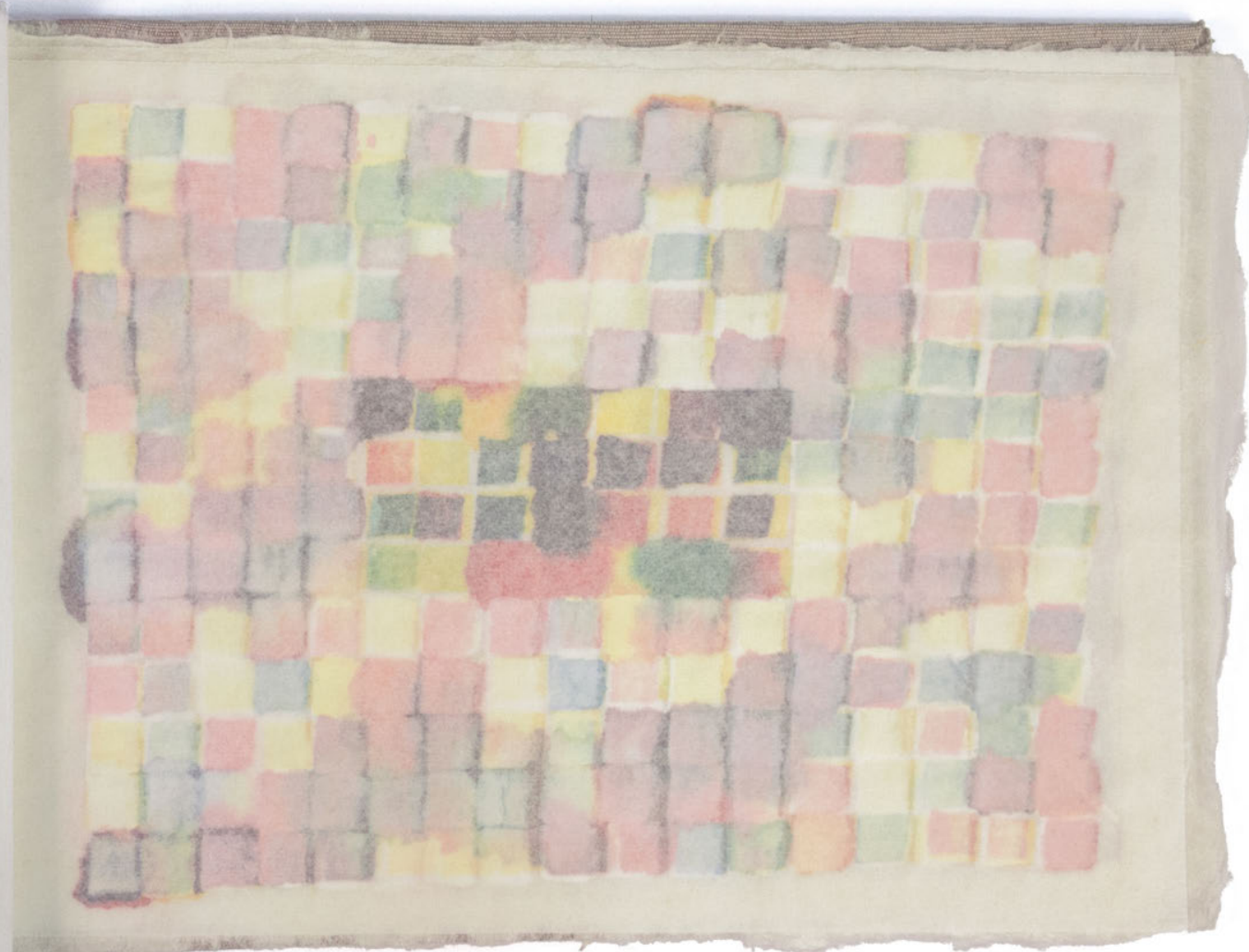



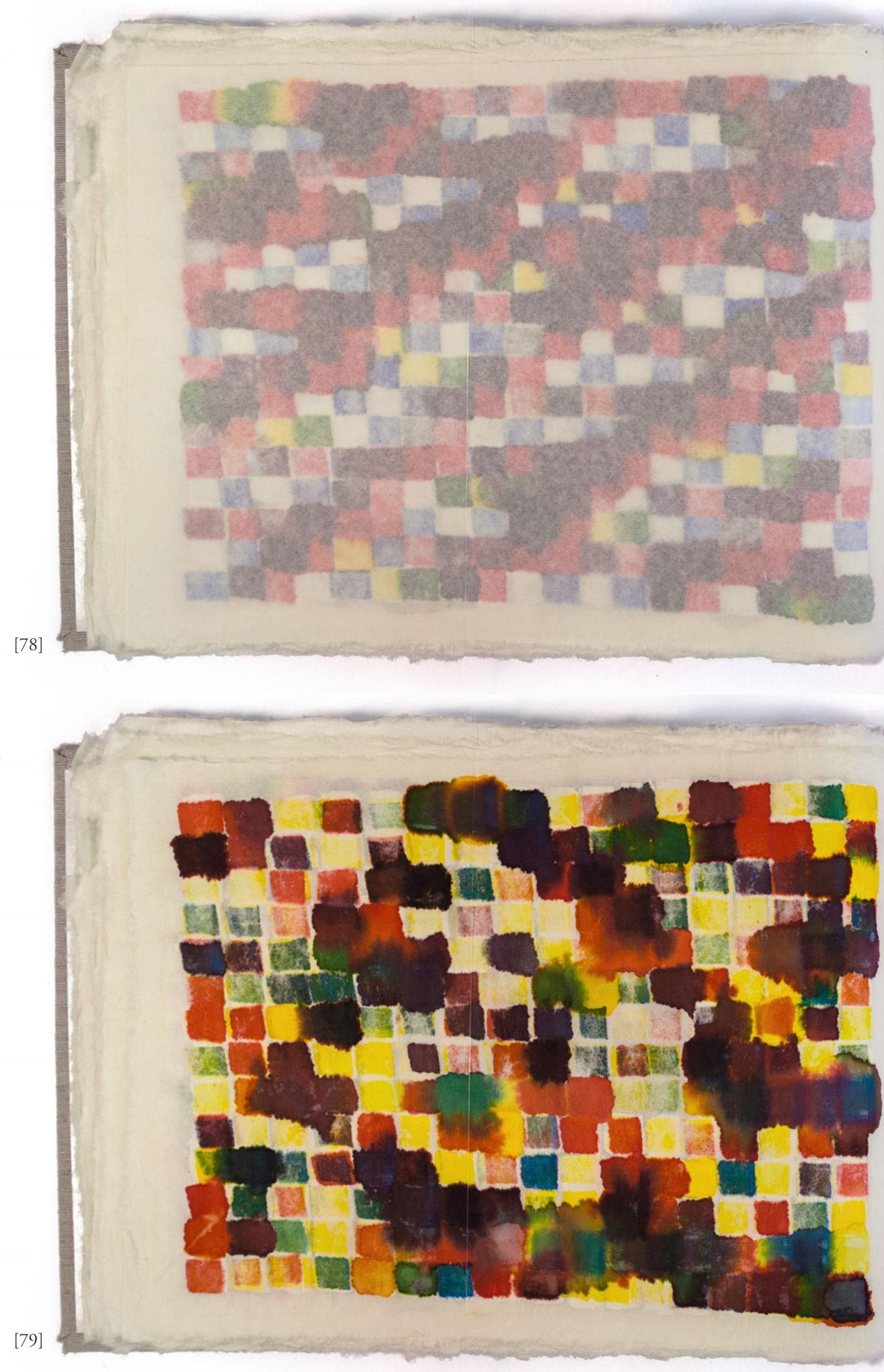

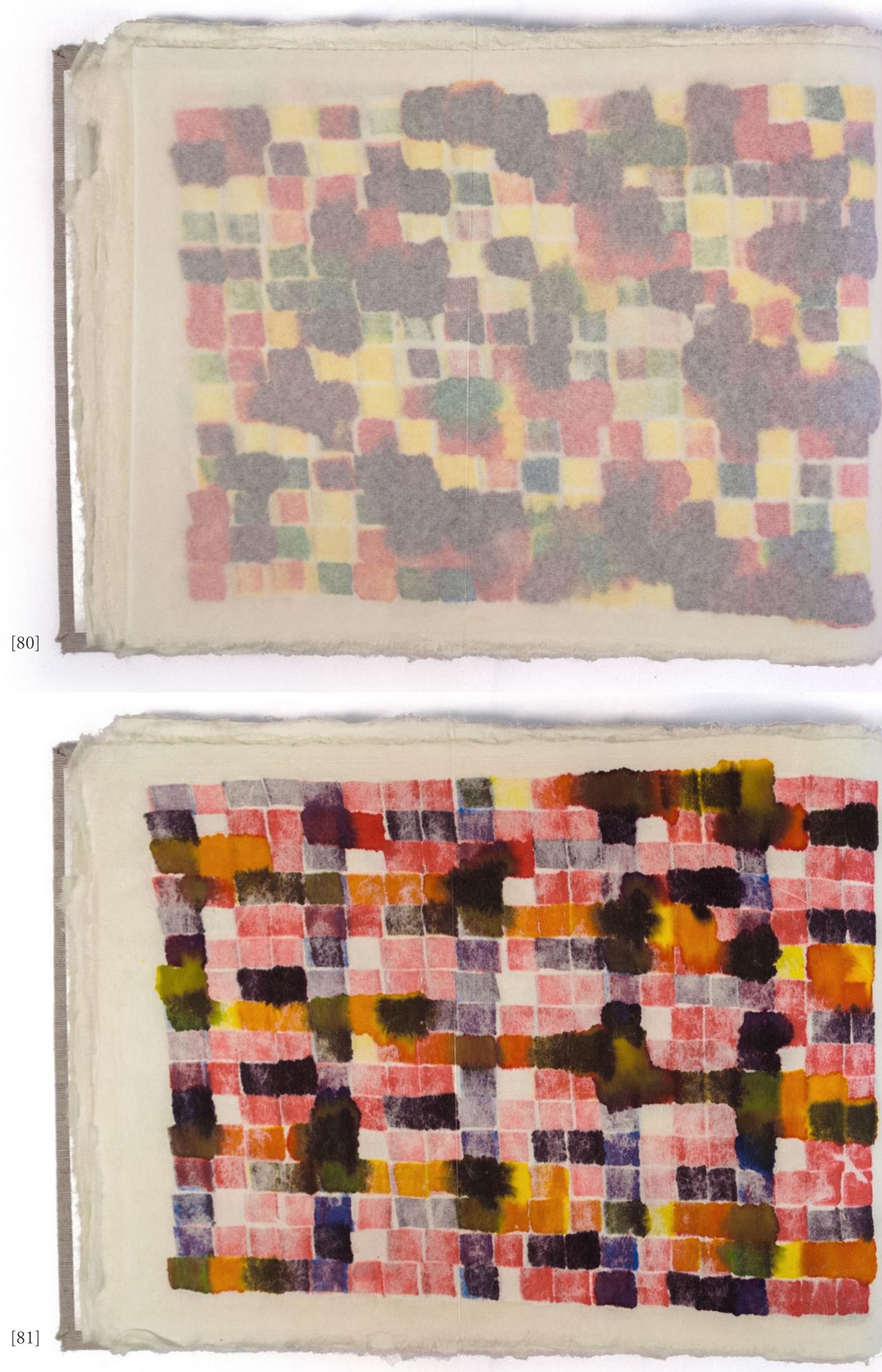


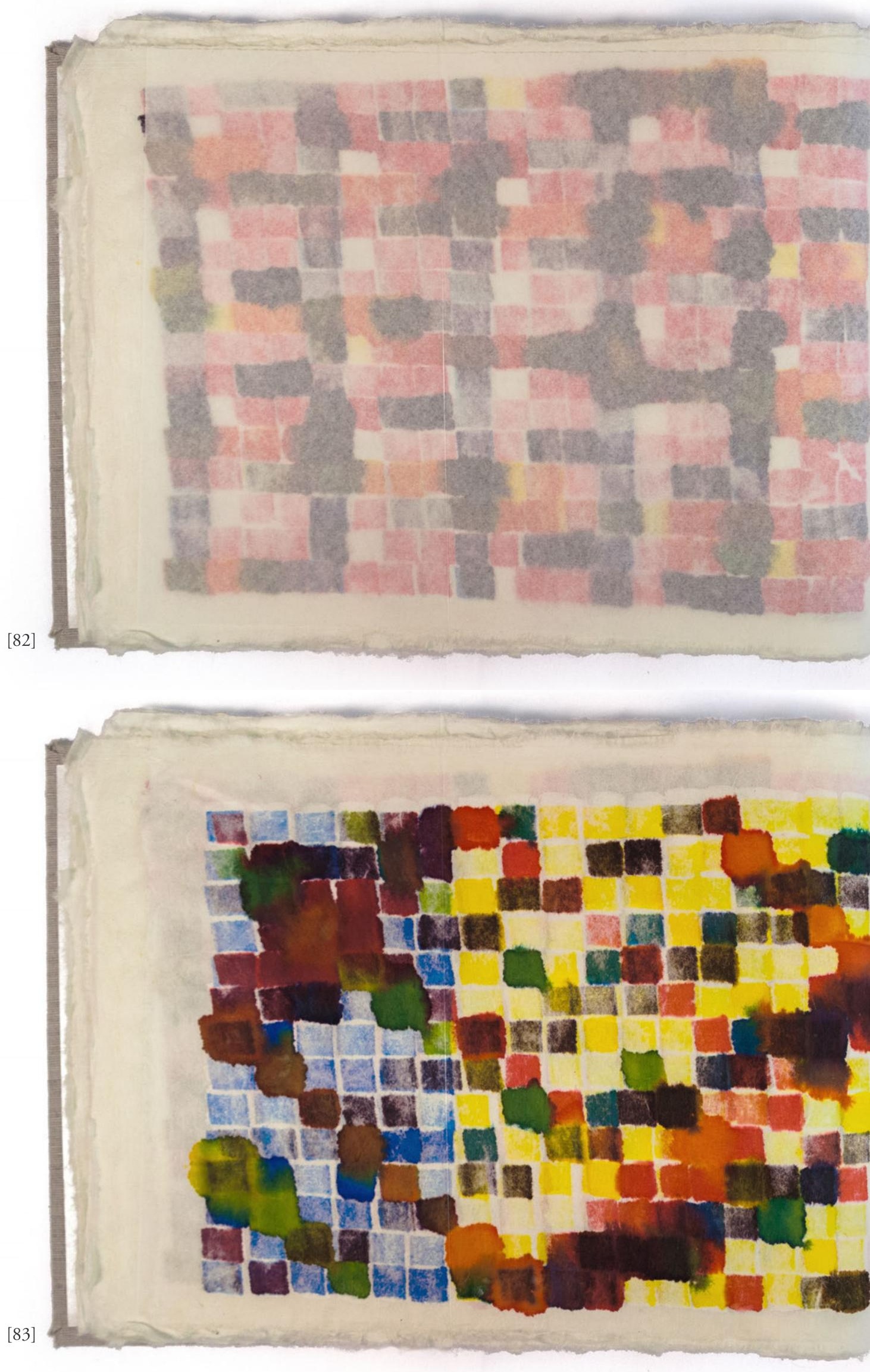




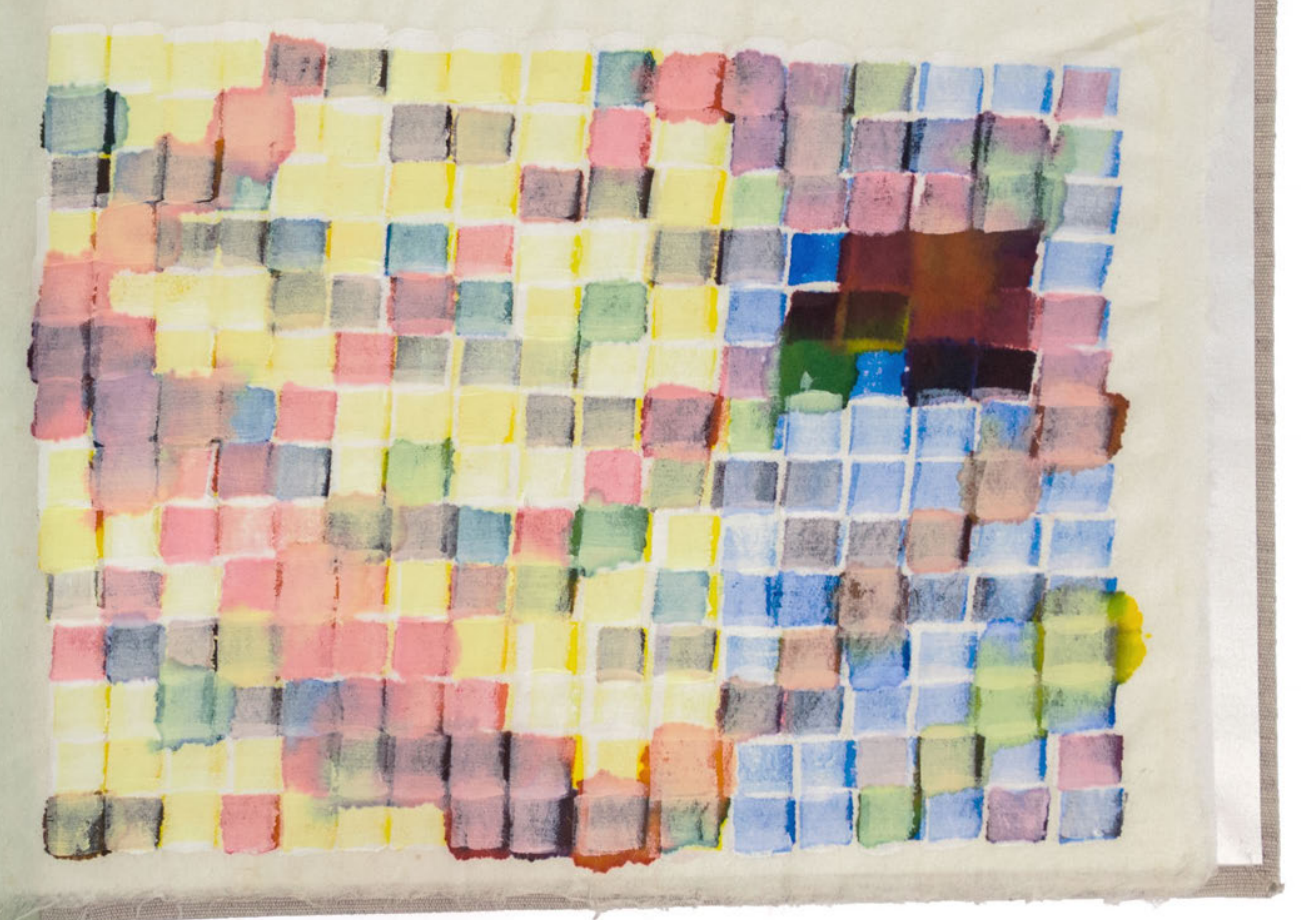



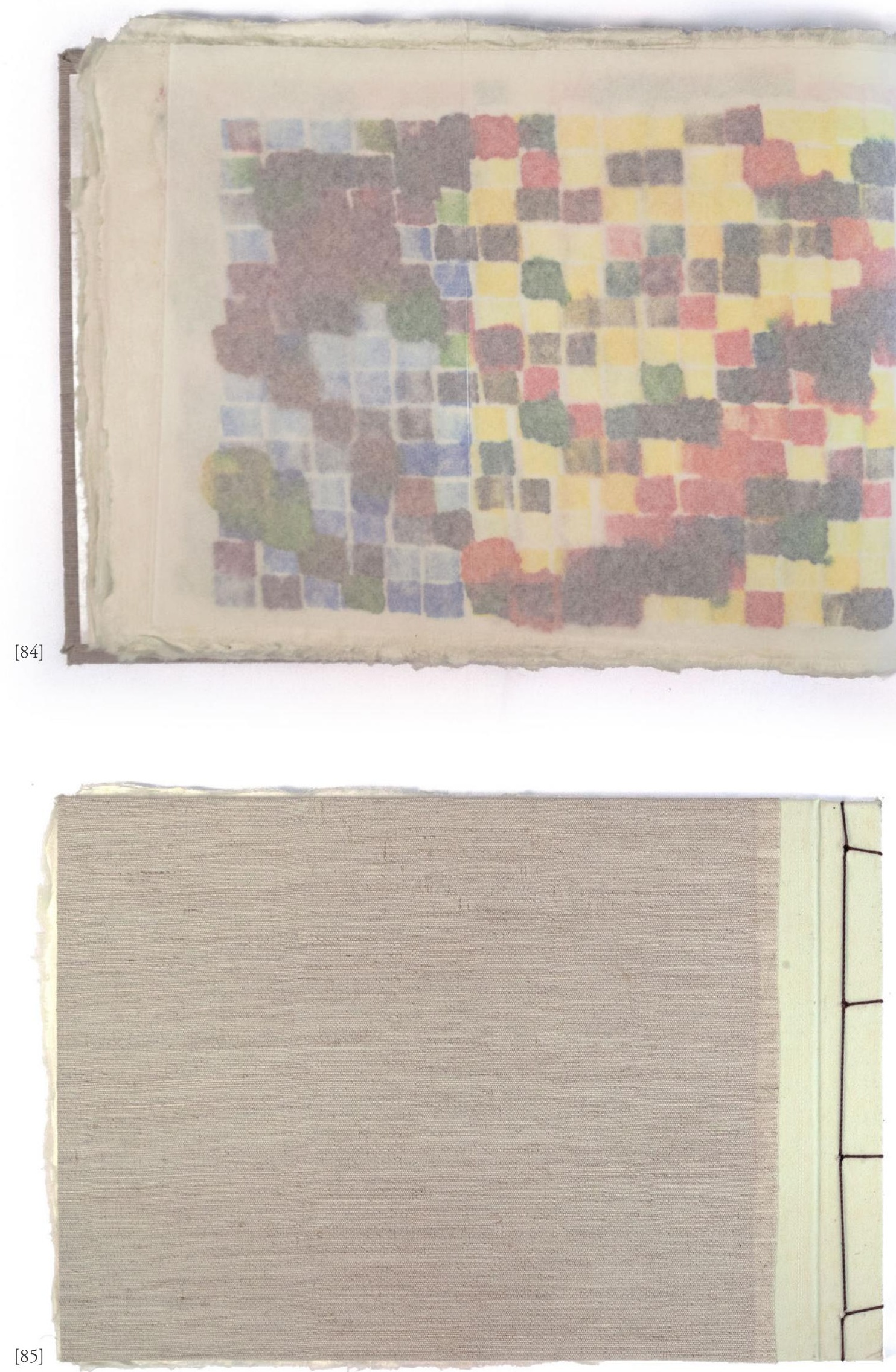


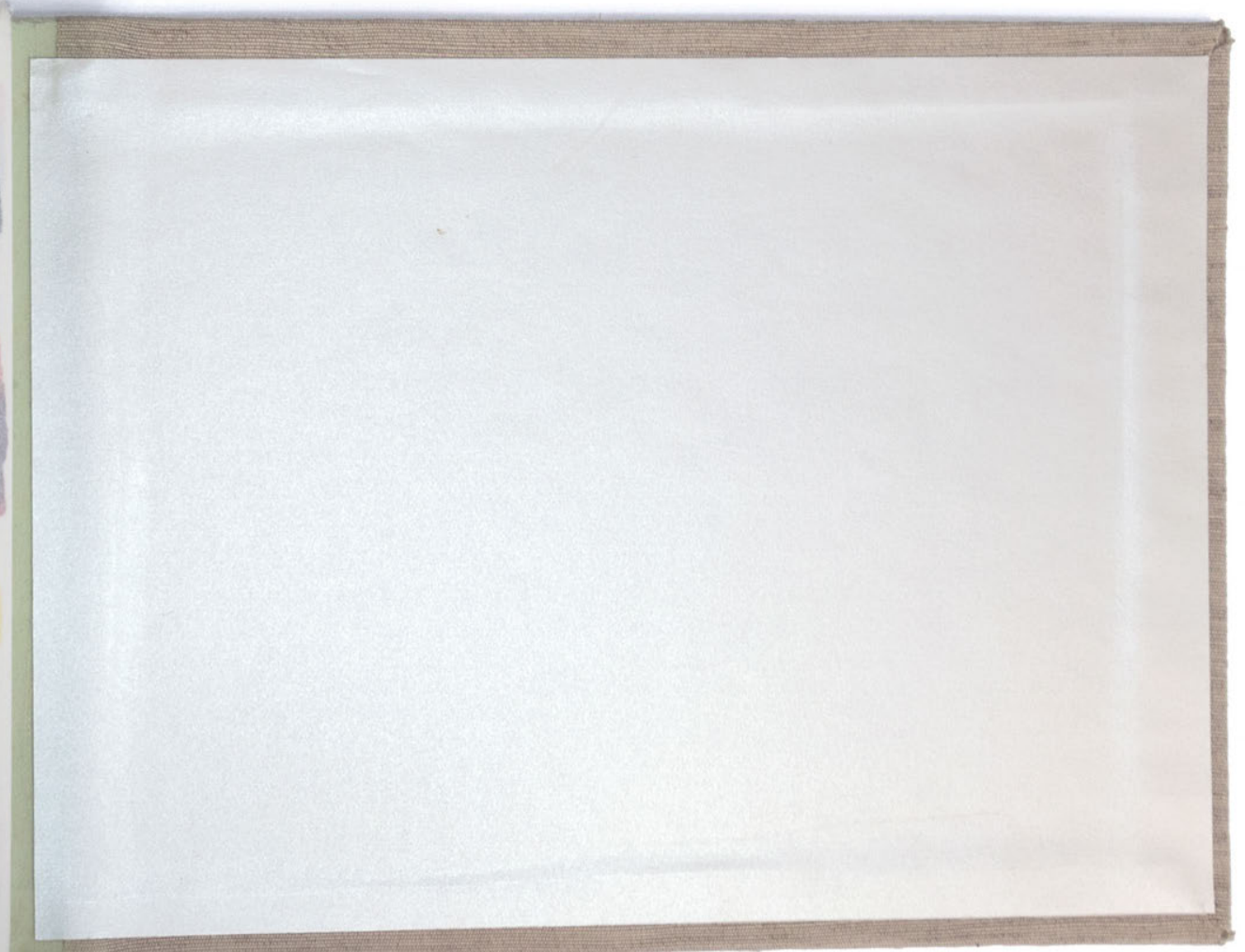



Depois do almoço, o sol, ciente de que era sábado, flanava uma hora a mais pelas alturas, $e$ quando algum de nós, julgando que já era tarde para o passeio, exclamava: "Como?! Apenas duas horas?!", ao ver passarem as duas badaladas da torre de Santo Hilário

Proust, Marcel. Em Busca do Tempo Perdido : No caminho de Swann, 149. 





\section{CÓDICE N.5}

O que mais me agradava nos livros era of fato de que aquilo que eles nos davam não se achava apenas dentro deles, mas o que nós, crianças, adicionávamos a eles é que fazia a história acontecer. Quando crianças, podiamos realmente ler entre as linhas e acrescentar-lhes toda a nossa imaginação. Nossa imaginação realmente complementa as palavras. Quando comecei a assistir aos filmes, era assim que eu os via. Queria ler entre as linhas, e, na época, isso era possivel. Nos faroestes de John Ford, era possivel ler entre as imagens. Havia tanto espaço entre as tomadas que podíamos nos projetar dentro dele. Hoje os filmes são totalmente fechados, enclausurados. Não há mais espaço para o interior dos sonhos. A maioria dos filmes contemporâneos não nos deixa mais nenhum espaço. O que você é o que você recebe. Não é preciso introduzir neles os próprios sonhos: chegam prontos. ${ }^{40}$

O wabi-sabi, como conceito estético, representa na pesquisa um recurso para

\footnotetext{
${ }^{40}$ Joăo Jardim e Walter Carvalho, A janela da alma, NTSC, colorido, Documentário (Europa filmes, 2001), 21:43-22:48.
} 
adentrar na complexa cultura nipônica. Formada por uma concepção de mundo singular, ela se desdobra em manifestações artísticas e práticas culturais típicas desse povo. O sabi, como também é conhecido, é a representação estética do reconhecimento do belo na passagem do tempo e da consequente impermanência de tudo que há. Essa visão de mundo está incrustada no Japão e se manifesta em linguagens como na prática da pintura, no arranjo floral (ikebana), na cerimônia do chá (chanoyu) e no zen budismo (a vertente sino-nipônica da religião indiana). ${ }^{41}$ Semelhantemente, outro conceito de difícil definição presente na cultura japonesa é o ma.

Ao inquiri-lo, novamente despontam advertências quanto à impossibilidade de seu entendimento a partir da lógica. ${ }^{42}$ Assim como acontece com o sabi, é preciso senti-lo para compreendê-lo com a diferença de que enquanto o sabi se relaciona com a estética, o ma diz respeito ao espaço. Tradicionalmente o espaço ocidental é compreendido por meio da perspectiva - construção gráfica antropocêntrica, cuja visão tem em seu centro o olho de um homem de estatura média. Com apenas um olho aberto e focado em um ponto fixo, a representação se dá com o uso de linhas. ${ }^{43}$ Nela, as formas são desenhadas, enquanto o espaço excedente entre os objetos é visto como vazio. No entanto, para a compreensão do ma é preciso rever essa definição de vazio. Por um lado, no Ocidente chamamos os objetos representados pela perspectiva como espaço positivo, e o espaço restante como negativo, estabelecendo dessa maneira uma dicotomia entre cheio e vazio, entre forma e

\footnotetext{
${ }^{41}$ Mais informações em relação a visão do belo na passagem do tempo, existente no contexto japonês, e a sintaxe formal pela qual ela se manifesta em Michiko Okano, Ma : entre-espaço da arte e comunicação no Japão (São Paulo: Annablume, Fapesp, Fundação Japão, 2012), 51-52.

${ }^{42}$ A impossibilidade de tradução do ma em temos lógicos em Ibidem, 23-24.

${ }^{43}$ Conceituação do espaço perspective em Erwin Panofsky, Perspective as symbolic form, 6o ed (Estados Unidos da América: Zone Books, 2012), 28-31.
} 
contraforma. Por outro lado, no ma não é possível falar em espaço positivo ou negativo, ambos possuem igual importância e são vistos interdependentemente, pois um não existe sem o outro. Dessa maneira, o vazio não é compreendido como algo negativo, o espaço que nada contém, mas sim um local radicalmente disponível de possibilidades e que tudo pode abrigar. ${ }^{44}$

A consequente mudança de abordagem acarreta o encontro de potencialidades em espaços de transiçấo vistos como sem funçấo no Ocidente. $\mathrm{Na}$ arquitetura isso pode se dar na presença de áreas de transição entre os lados de dentro e de fora em uma construção; já no cinema, é visível a existência de planos onde aparentemente nada de muito significativo acontece, intermediando dois momentos de açáo. A ideia de explorar o intervalo como relação entre etapas se torna clara no exemplo do Santuário de Ise, exposto logo abaixo. Nele, diversos espaços $m a$ estão presentes no trajeto onde, ao final, se vê o santuário de longe, por trás de uma cerca. Portanto, o ponto final não é o objetivo. Visitar esse santuário é experienciar o percurso em cada momento, levando o visitante desavisado à frustraçáo caso deseje somente alcançar o momento final do trajeto. Por outro lado, quando apreciada em sua totalidade, a visita adquire um novo significado.

No Santuário Ise, da província de Mie, Japão, privilegia-se a compreensão única do espaço-tempo, o que é possivel exemplificar no sandô (espaço de peregrinaçâa - da entrada do torii até a fren-

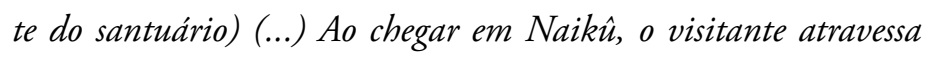
a primeira espacialidade ma representada pelo grandioso portal Torii, que produz uma segunda, composta da ponte curvilinea de madeira sobre o rio. Esses três elementos são fronteiras iniciais entre a zona profana e a divina. O transeunte anda sobre a ponte,

\footnotetext{
${ }^{44}$ Apresentação da concepçâo de "vazio" na cultura japonesa em Okano, $M a$ : entre-espaço da arte e comunicação no Japão, 27-29.
} 
num aguçar das sensibilidades visual e auditiva: vê um bosque que se descortina no outro extremo da ponto Uji e ouve o som da correnteza do Rio Isizi, que passa por baixo. As percepçóes do espaço consistem, então, não só naquilo que se vê, como também nas associaçôes despertadas pelos cinco sentidos. A caminhada prossegue através dos pedregulhos; os passos são registrados pelo som produzido pelo pé em contato com as pedras. A dificuldade de caminhar sobre o pedregulho é uma das estratégias para enfatizar a diferença de mudança do território. Essa fronteira é reforçada quando se passa por uma zona de ablução onde se lavam a boca e as mãos, purificação necessária para penetrar o território divino, indicando a sua proximidade.

No final do trajeto, há um escada para alcançar o santuário (...) cuja entrada é proibida, não é objeto para ser experienciado corporalemente, mas algo para ser visto, e de longe, por entre cercas, denominadas kekkai, que são fronteiras fisicas e visuais, as quais delimitamo espaço do divino. ${ }^{45}$

O espaço ma é compreendido de modo amplo dentro da cultura japonesa, assumindo diferentes significados, dependendo da situação. Independentemente de onde seja utilizado, é característica a apreciação e compreensão da interconexão entre tudo. A relação entre os diversos conceitos japoneses não está presente apenas no fato de valorizarem o conhecimento empírico e individual, ma e sabi se entrelaçam em seus significados. O primeiro, como espaço intervalar, é também o grande processo, em constante mudança, em que tudo surge e um dia esvanece. Enquanto o sabi é o reconhecimento do belo na ininterrupta transformação que necessariamente desemboca na extinção de tudo.

Essas compreensões foram visualmente representadas por Hasegawa

\footnotetext{
${ }^{45}$ Okano, Ma : entre-espaço da arte e comunicação no Japão, 87-89.
} 


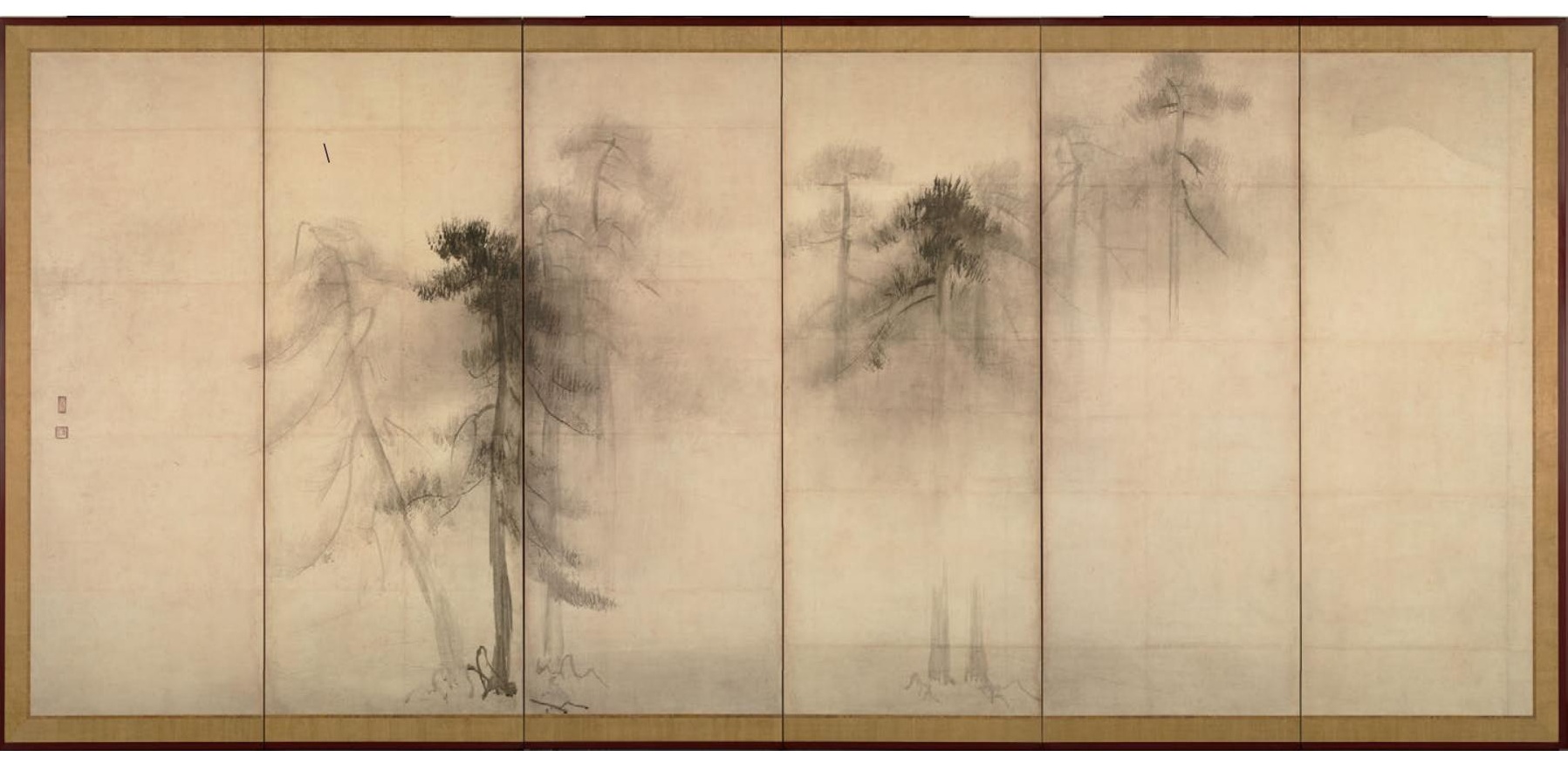

[86]

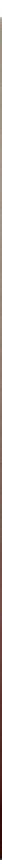

[87] 


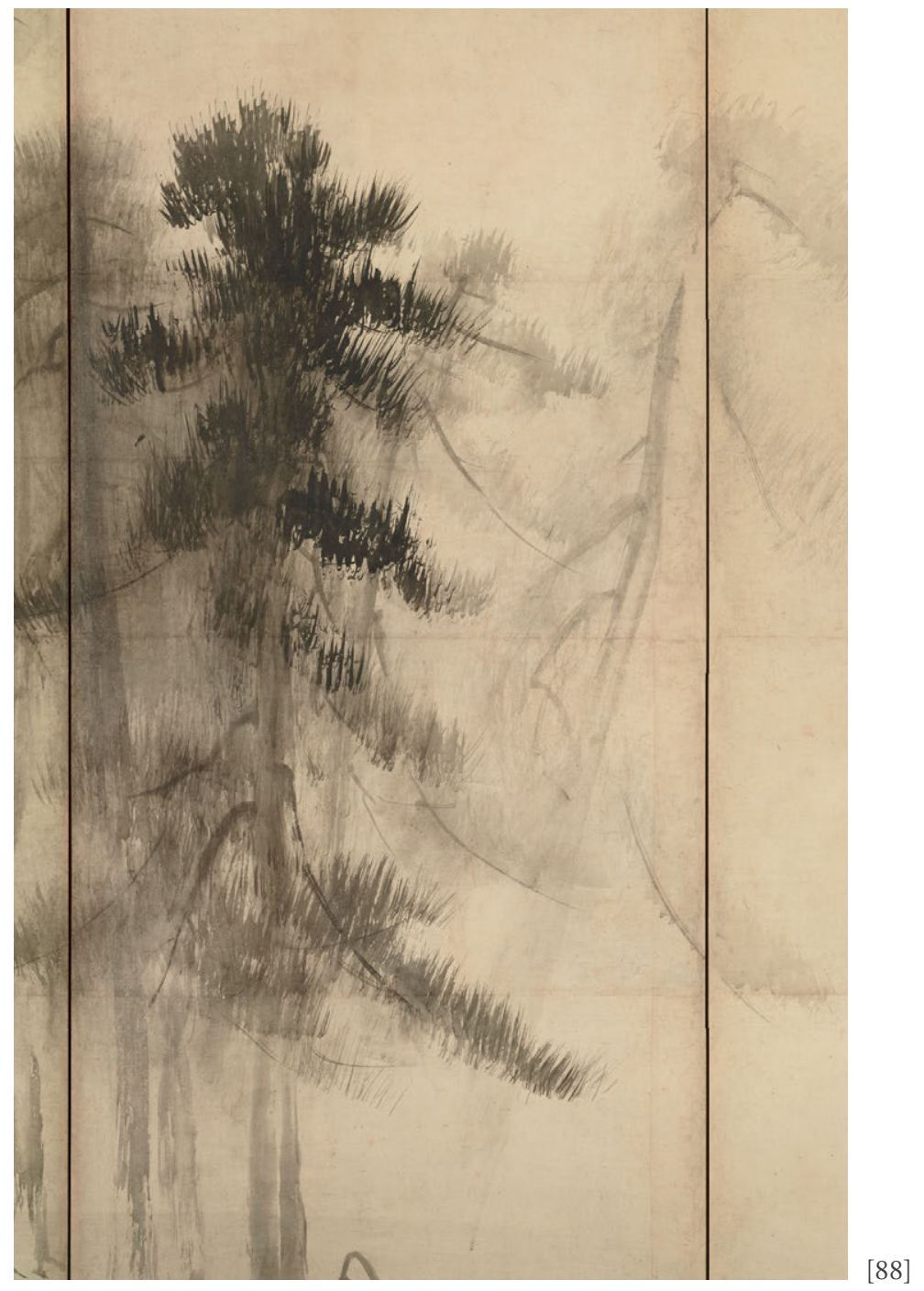


Tohaku. ${ }^{46}$ Em uma pintura, ele insinua, em decididas manchas de nanquim, um conjunto de copas que formam uma floresta de pinheiros. Nela, a profundidade sucumbe em um curto espaço à densidade da atmosfera, ocultando a multiplicidade de copas por trás da densa neblina. Feita em nanquim, a perspectiva atmosférica acontece com o diluir constante de nanquim em água, até esta se tornar completamente cristalina. Formado por um par de seis espaços verticais, o conjunto é composto em sua menor parte pelas pinceladas da pintura, totalizando cerca de $1 / 3$ de espaço efetivamente pintado. $O$ restante é formado de papel de arroz deixado em branco, sendo, no contexto da composição, a representaçấo da densa neblina. $\mathrm{O}$ cheio ou o suposto vazio não são opostos, ambos são igualmente pintura. Embora facilmente perceptíveis a superfície pintada e a intocada, é impossível desemaranhar o entrelaçamento das partes e seu espaço de transição. A pintura é uma só.

O Códice n.5 foi produzido no contexto das questôes do ma:, o cheio-vazio, a pintura em desvanecimento de Hasegawa Tohaku, a sinestesia existente na visita ao templo de Ise. Composto em papel manteiga, seu conteúdo é formado por fotografias e pequenos textos batidos na máquina de escrever. Nele, amplos espaços deixados sem preenchimentos permitem surgir, por meio da semi-transparência do papel, o difuso conteúdo das páginas seguintes. Tanto fotografias quanto os textos são pouco nítidos, ou porque a tinta da máquina está quase a acabar - em muitos casos só é percebido o relevo deixado pela máquina - ou por conta das fotografias impressas em tinta translúcida. Nas fotos, são registrados pequenos detalhes do cotidiano, nelas nunca há a presença de pessoas. Já as pequenas frases representam sons do cotidiano que costumam passar despercebidos.

\footnotetext{
${ }^{46}$ Hasegawa Tōhaku, Shōrin-zu byöbu (Pinheiros), Par de seis pranchas, tinta sobre papel, 1610 de 1539.
} 



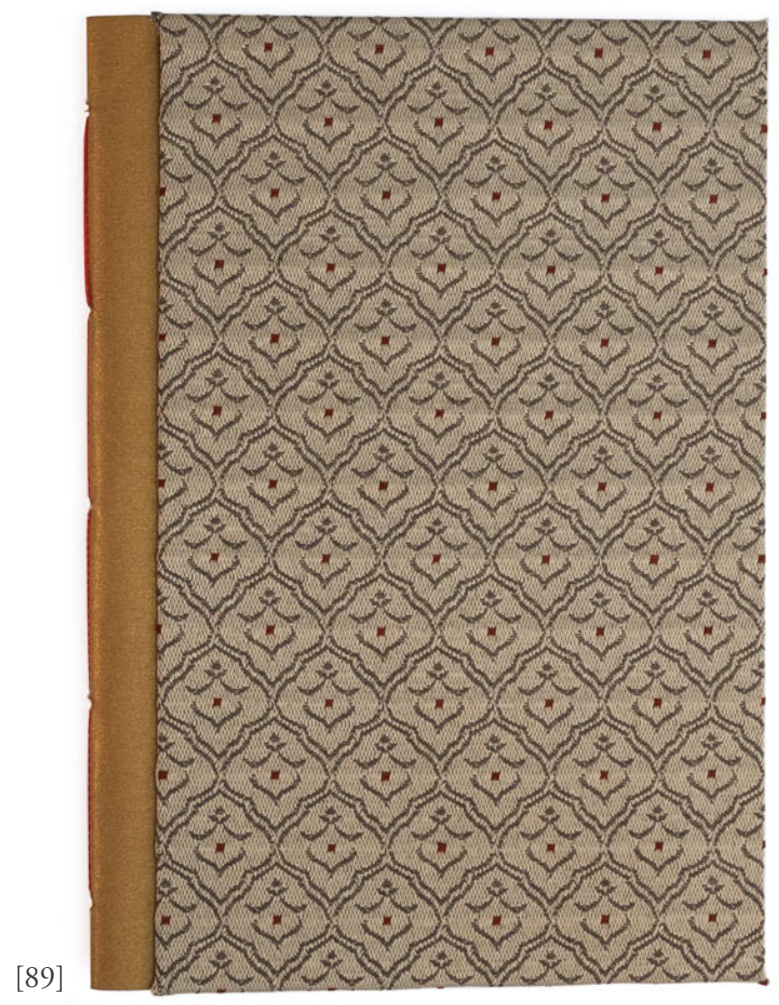

\section{CÓDICE N.5}

Técnica mista (papel-manteiga, papel vegetal, tecido, linha encerada, impressão jato de tinta, grafite).

$14,9 \times 21,1 \mathrm{~cm}$ (fechado)

$29,9 \times 21,1 \mathrm{~cm}$ (aberto)

2016

(Ver DVD anexo) 

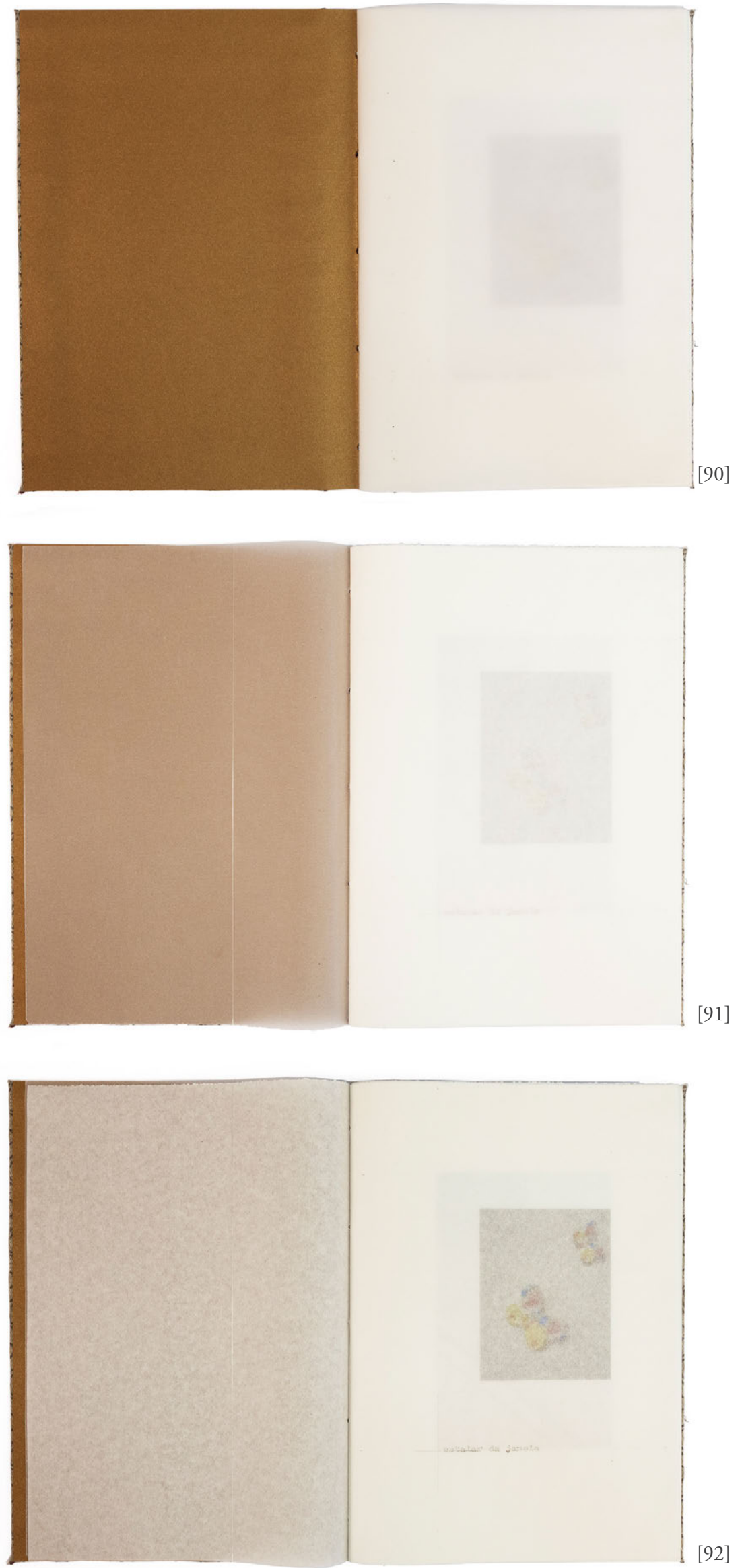

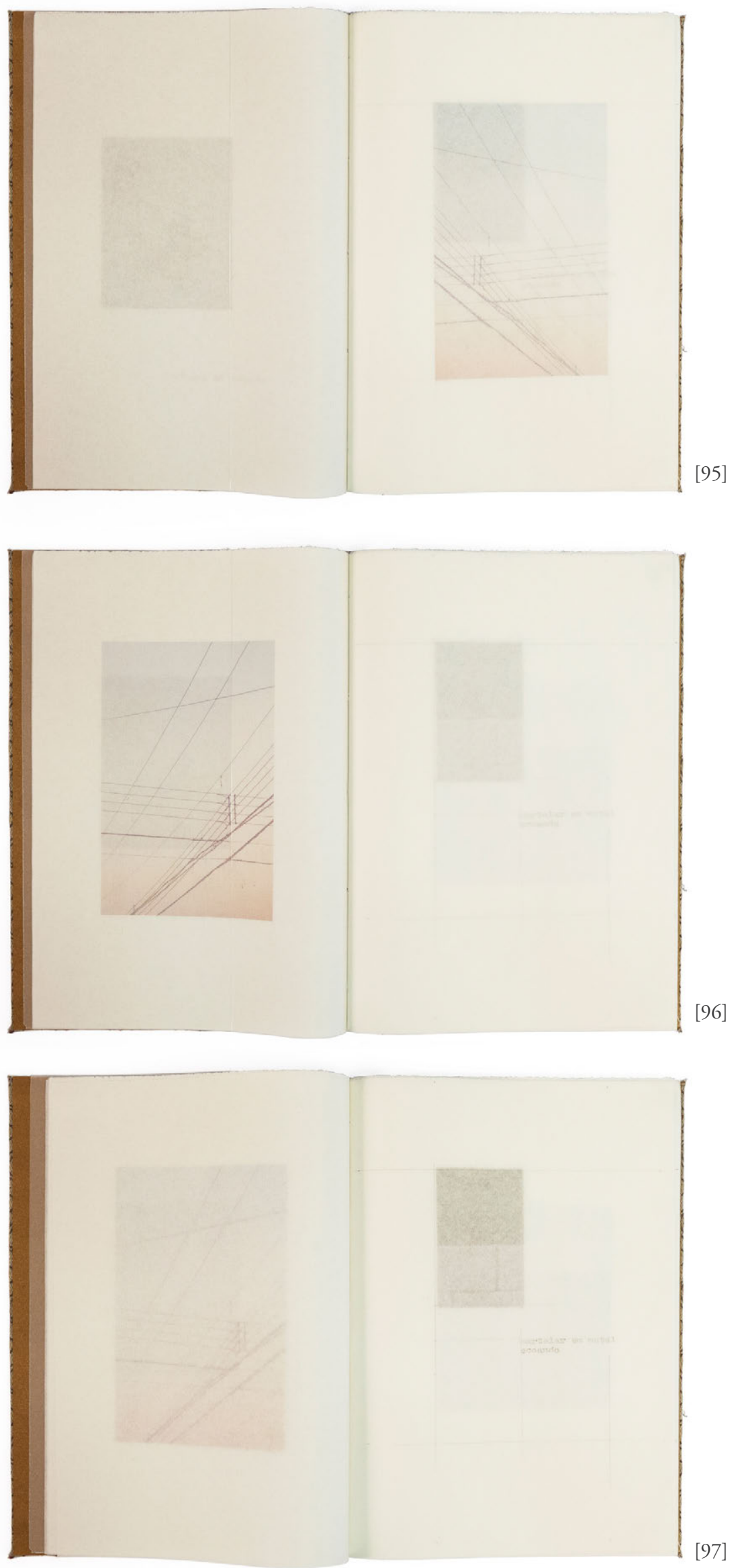

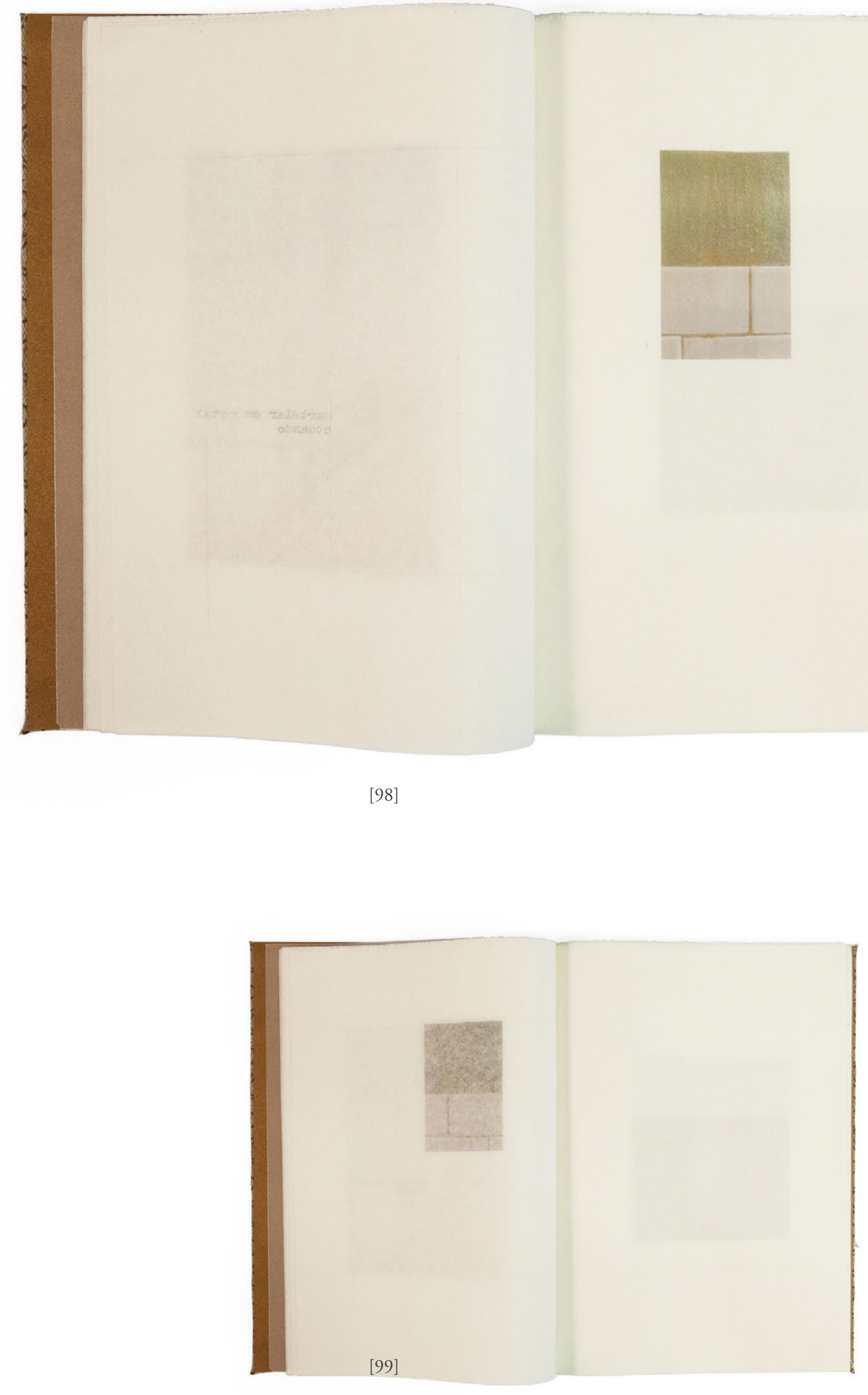

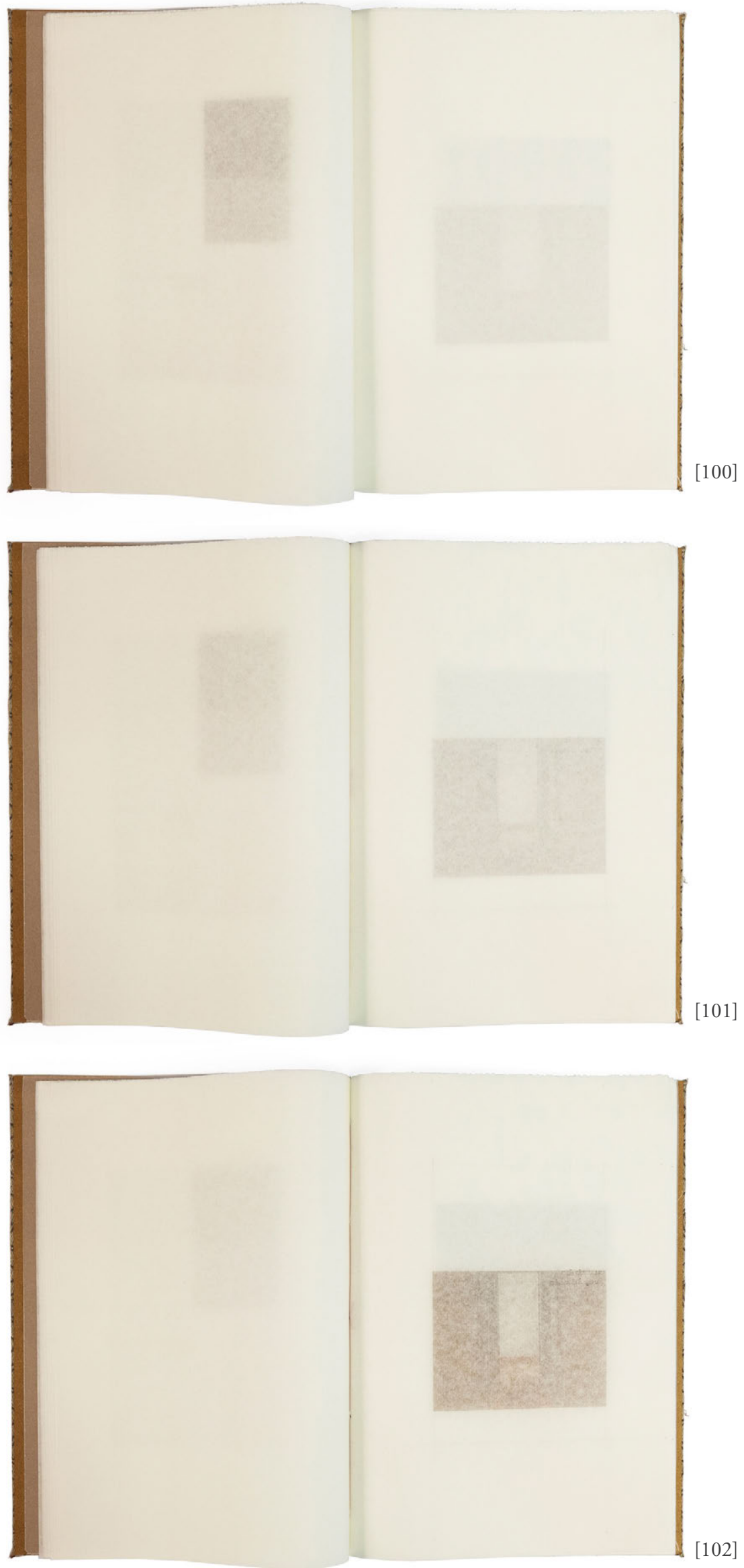

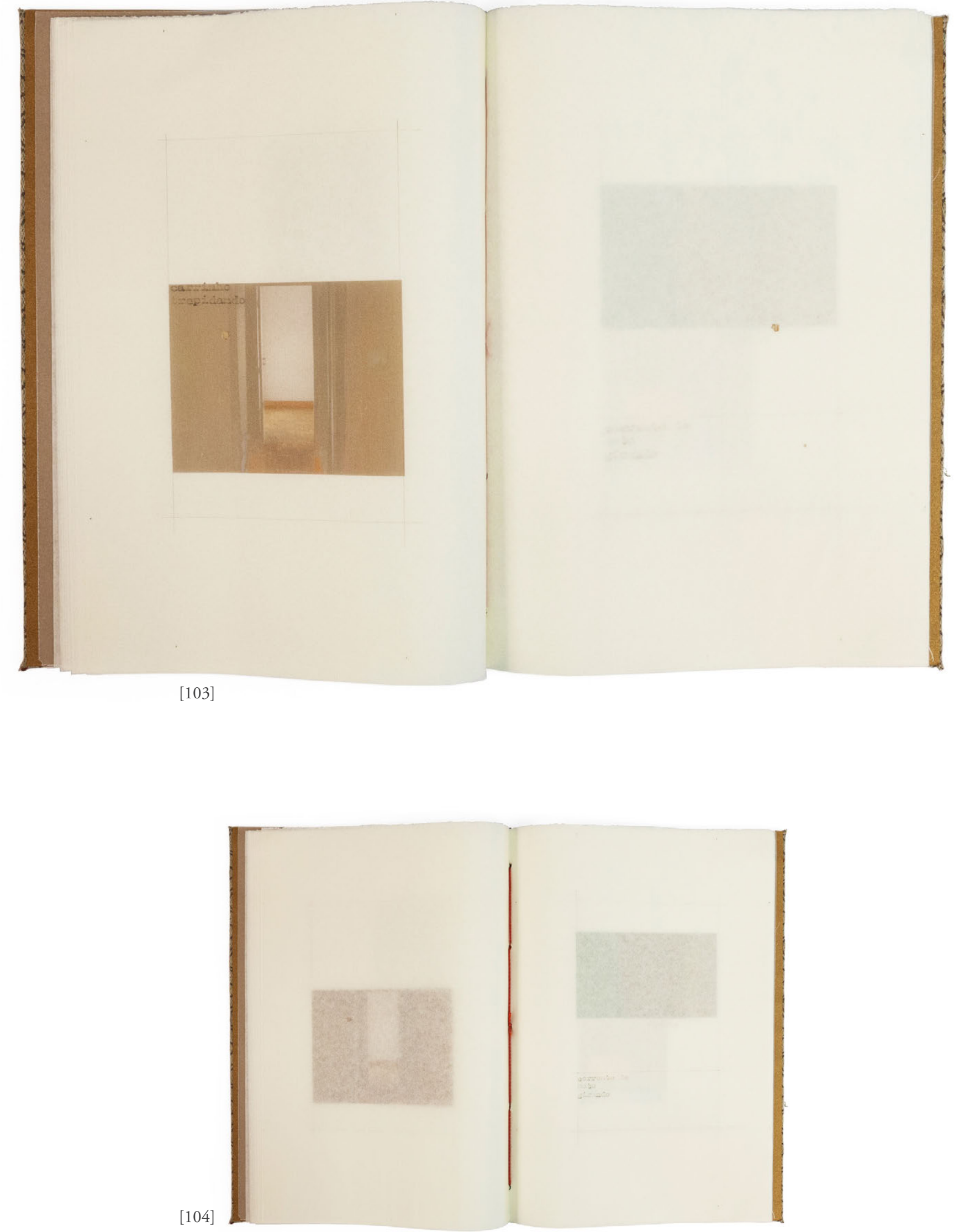

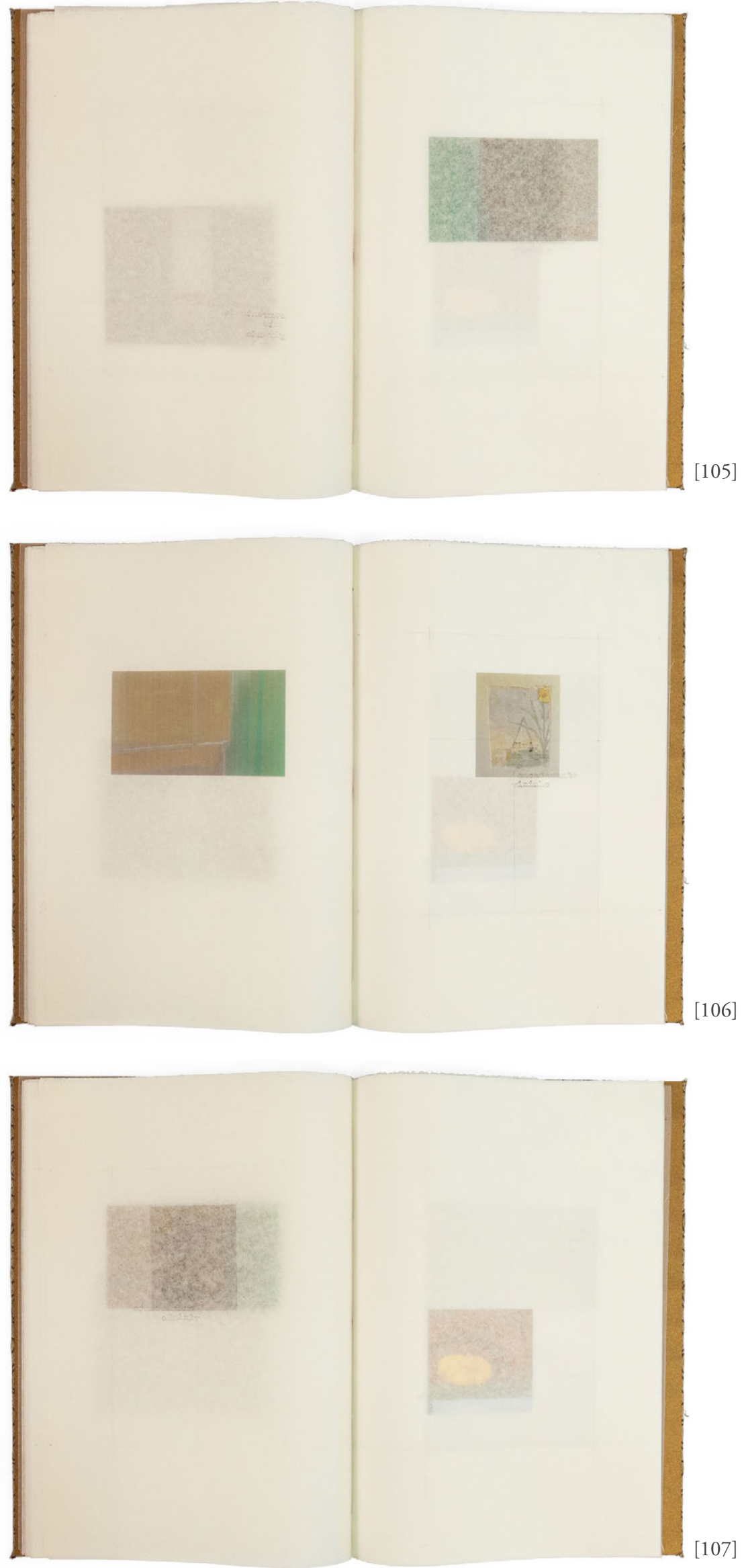

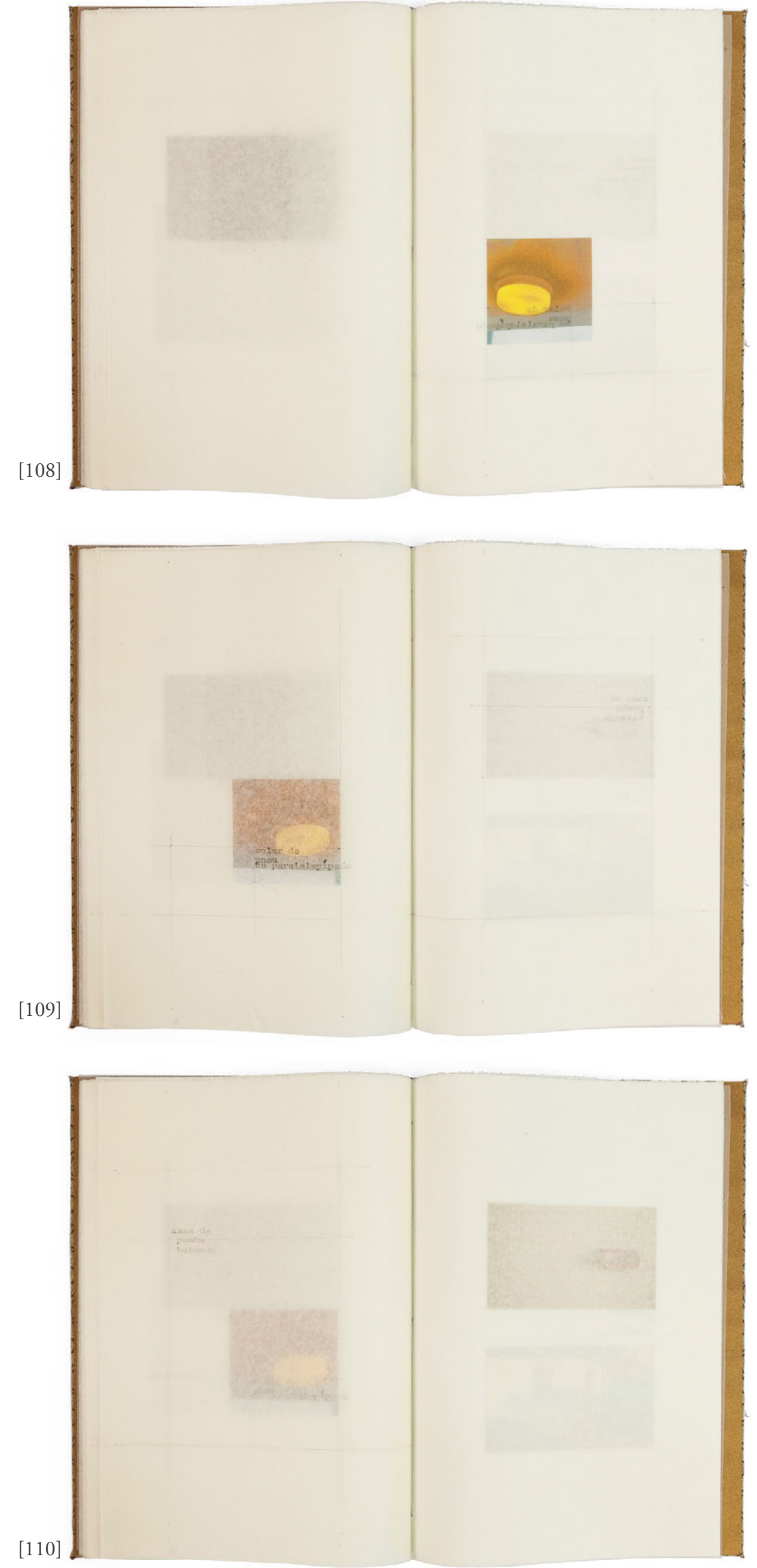


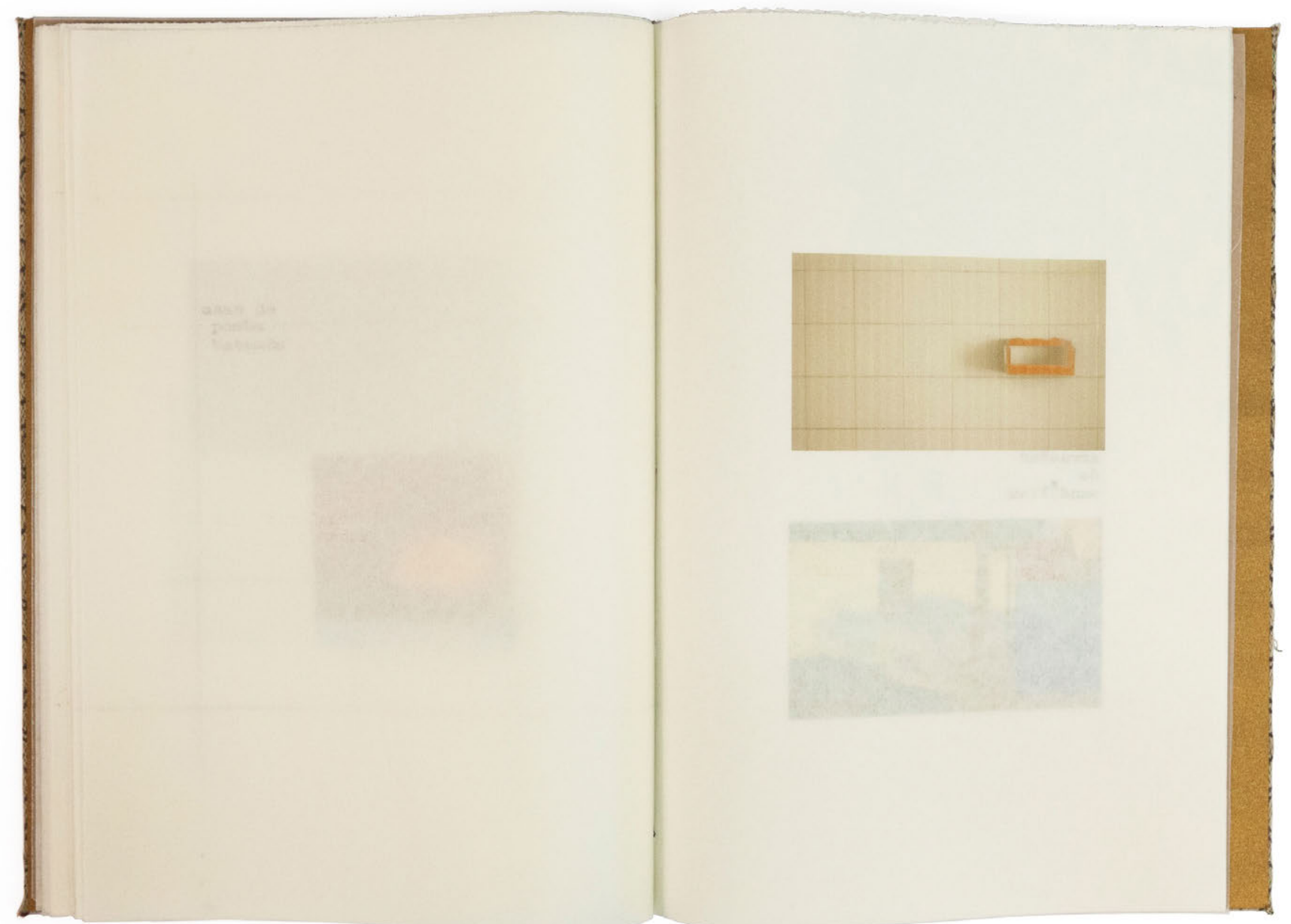

[111]

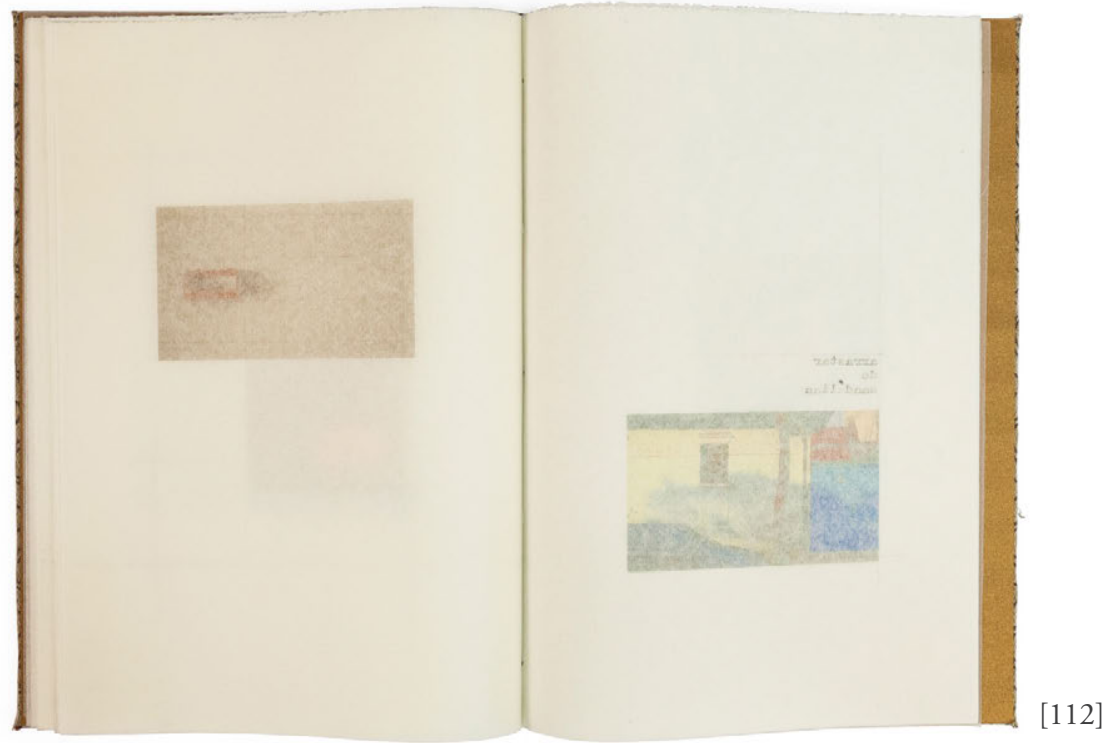



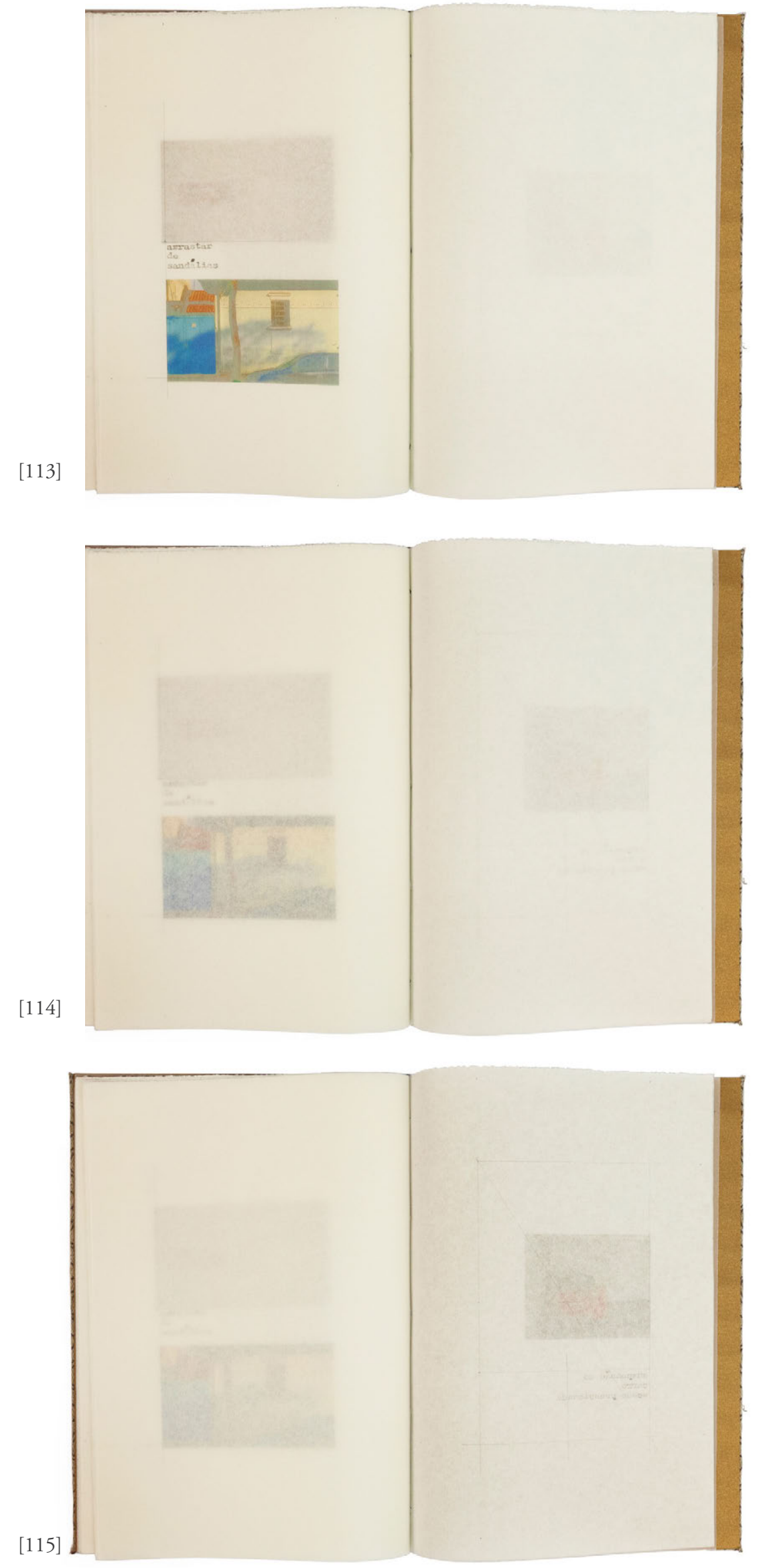


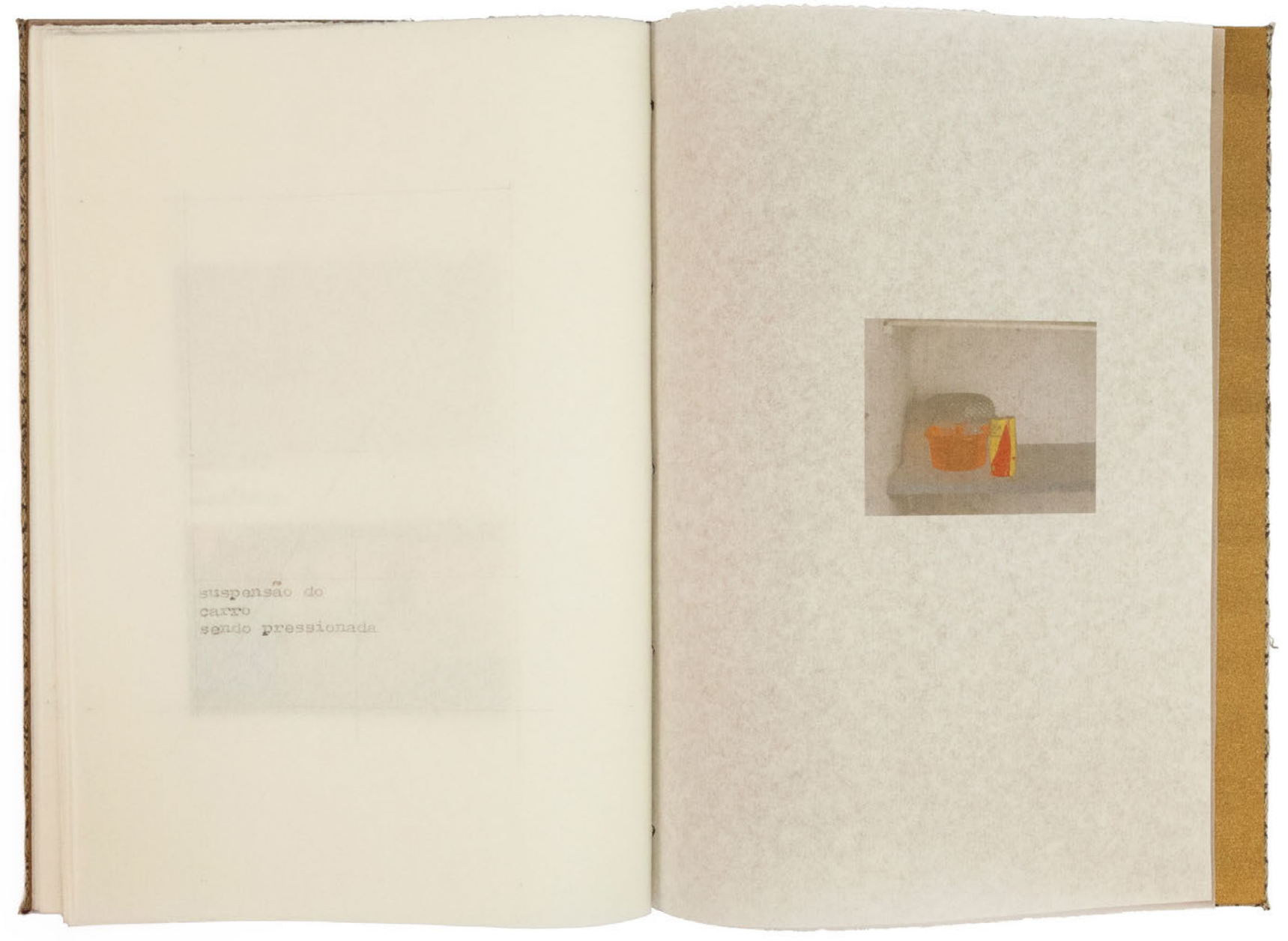

[116]

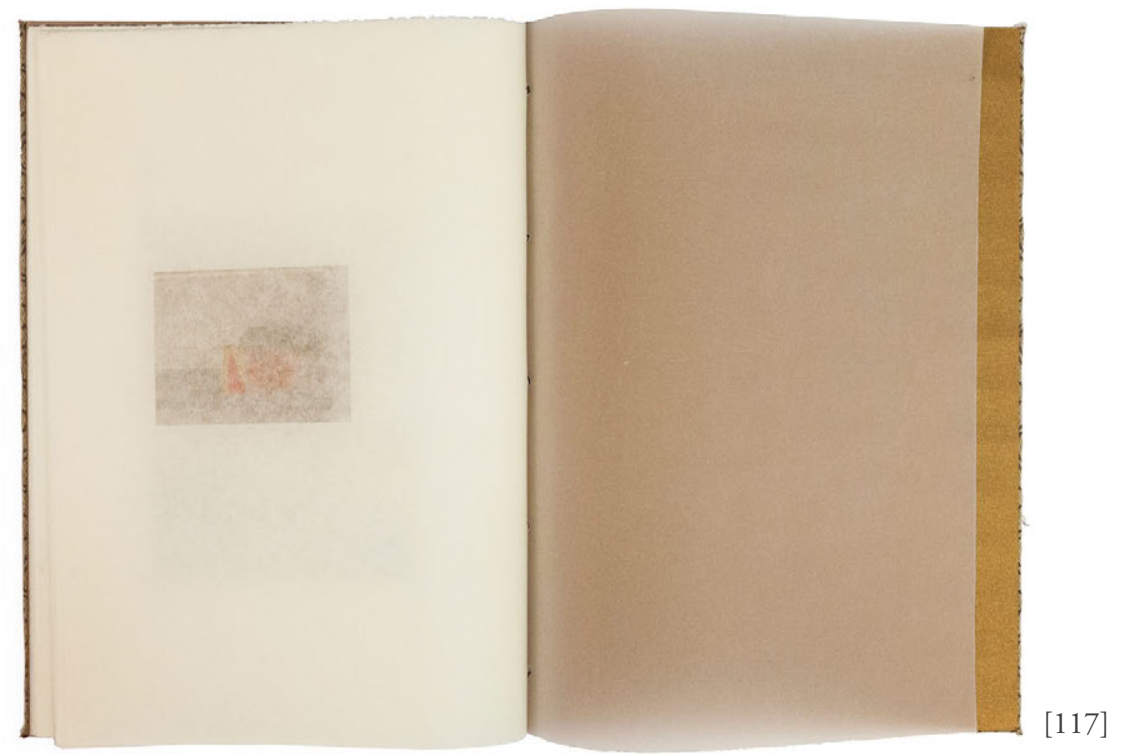




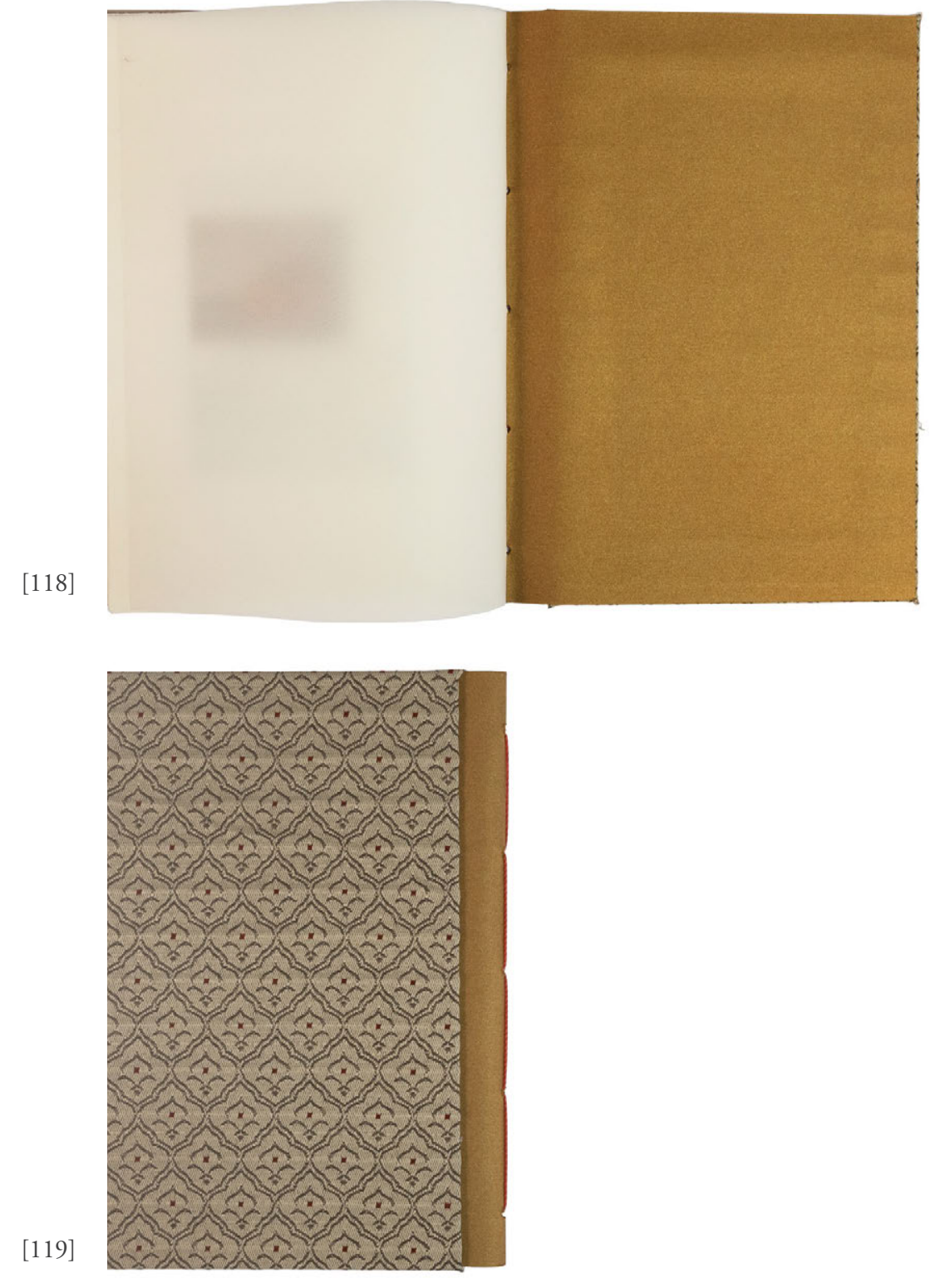



O esforço que fazia Elstir por despojar-se, em presença da realidade, de todas as noçôes da sua inteligência era tanto mais admirável, porque esse homem - que antes de pintar se tornava ignorante, esquecia-se de tudo por probidade, pois o que se sabe não é a gente - possuía uma inteligência excepcionalmente cultivada.

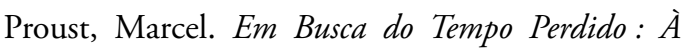
sombra das raparigas em flor, 492. 





\section{CÓDICE N.6}

At the time the mountains were climbed and the rivers crossed, you were present. Time is not separete from you, and as you are present, time does not go away. ${ }^{47}$

Os Códice n.4 e n.5, juntamente com seus subsequentes textos, trouxeram para a pesquisa os conceitos de wabi-sabi e ma, indicando novas abordagens em relação ao tempo suspenso. Ambos abriram possibilidades para a questão do tempo inicialmente levantada, como a busca por vivenciar a suspensão do tempo para impregná-lo nos códices, ou as mudanças nas escolhas formais da estética, de composição, de materiais, ou modo no uso dos espaços vazios - para a produção das páginas dos livros. Agora, retomo as ideias já desenvolvidas para aprofundá-las e desdobrá-las em um novo códice.

De difícil conceituação, o sabi representa, como categoria estética, objetos que

\footnotetext{
47 “No momento em que as montanhas foram escaladas e os rios cruzados, você estava presente. O tempo náo é separado de você, e a partir do momento que você está presente, o tempo não vai à lugar algum." Eihei Dogen, The Essential Dogen - Writings of the Great Zen Master (Estados Unidos da América: Shambhala Publications, 2013), 92, nossa tradução.
} 
abrigam em suas superfícies a consciência da impermanência de tudo o que existe na vida, no constante fluxo de mudanças indissociáveis do transcorrer temporal. Essa visão de mundo se manifesta esteticamente na cultura nipônica por meio da apreciação do simples, transitório, sutil e imperfeito em objetos com assimetria, imperfeiçôes, materiais que se degradam (como a madeira), cores esmaecidas e dessaturadas e sutis transições tonais. ${ }^{48}$ Objetos com essas características podem ser encontrados na cerimônia do chá (chanoyu). Nela todos os utensílios utilizados são previamente escolhidos com o objetivo de, ao final, serem contemplados pelos participantes e incitarem sentimentos de serenidade, melancolia e anseios espirituais. ${ }^{49}$

O wabi-sabi e o ma são conceitos estéticos e se manifestam de diferentes maneiras nas inúmeras práticas artísticas japonesas, tendo todas como pano de fundo a origem comum no zen-budismo. ${ }^{50}$ Tais atividades têm a finalidade de alcançar resultados semelhantes, se não os mesmos, dos monges zen-budistas, para isso utilizando como instrumento a prática da pintura, da cerâmica, da esgrima ou de outras manifestaçóes artísticas/culturais, podendo quase todas as profissōes tradicionais do Japão ${ }^{51}$ se enquadrar nessa categoria, nas quais

\footnotetext{
${ }^{48}$ Apresentação aprofunda da sintaxe visual em elementos pertencentes ao wabi-sabi em Andrew Juniper, Wabi sabi : the japanese art of impermanence (Singapura: Tuttle Publishing, 2003), 103-120.

${ }^{49}$ Comentários específicos sobre a contemplação dos objetos durante a cerimônia do chá em Ibidem, 10-11. Comentários aprofundados sobre a origem da cerimônia, escolas e relação com o taoísmo e zen-budismo em Kakuzo Okakura, O livro do chá, trad. Leiko Gotoda (São Paulo: Estação Liberdade, 2008).

${ }^{50}$ A maneira como se dá a relação entre o wabi-sabi e o zen-budismo nas produçóes artísticas japonesas a partir da ideia de a obra refletir o estado interior do artista em Juniper, Wabi sabi : the japanese art of impermanence, 119.

${ }^{51}$ A tradição espiritual nas tradicionais profissões japonesas, conhecidas por do, em Allan Watts, The way of zen (Nova York, Estados Unidos da América: Vintage
} 
a produção em si é vista como consequência do estado interior almejado. ${ }^{52}$ Gusty Herrigel descreve sua experiência ao se mudar da Alemanha para o Japão e tomar contato com o ensinamento de uma dessas tradicionais atividades: o ikebana (a arte dos arranjos florais). ${ }^{53}$ Segundo a orientação do mestre, a realização do ikebana deve começar logo ao acordar, com a busca de equilíbrio e da harmonia interna em todas as atividades diárias, sendo o arranjo floral apenas uma etapa no processo que não começa e nem termina com a finalização da composição. ${ }^{54}$ Comum a outras linguagens tradicionais japonesas, tal aconselhamento também aparece na atividade da caligrafia, nela o praticante não deve forçar ou desejar um resultado exterior, pois a única questão colocada é a busca do equilíbrio interior para se alcançar a prática adequada. Dessa maneira, as ações envolvidas na preparação dos materiais e o momento da escrita são termômetros e registros externos, evidenciando se a serenidade e o equilíbrio interior foram efetivamente alcançados pelo praticante. ${ }^{55}$

Descriçóes semelhantes podem ser encontradas em relaçáo à cerimônia do chá (chanoyu), tiro com arco, esgrima, pintura e haikai. A lista de práticas artísticas é extensa. Surge como semelhança entre todas a constante busca por um objetivo comum: alcançar um estado de espírito específico para produzir

books, 1989), 176-177.

${ }^{52}$ A busca de uma experiência interior através do tiro com arco no livro Eugen Herrigel, $A$ arte cavalheiresca do arqueiro zen, trad. J. C. Ismael (São Paulo: Pensamento, 2011), em especial as páginas 25 e 26.

${ }^{53}$ A autora descreve seu contato com o ikebana e apresenta os principais caracteristicas dessa atividade em Gusty L. Herrigel, O zen na arte da cerimônia das flores (São Paulo: Pensamento, 2013).

${ }^{54}$ Descrição sobre o processo da prática diária em Ibidem, 39.

${ }^{55}$ Apresentação sobre a impossibilidade de reprodução de uma obra que represente o wabi-sabi e descrição da prática da caligrafia em Juniper, Wabi sabi : the japanese art of impermanence, 92-93. 
a obra e a própria produção dela como ponto condutor ao estado interior desejado. Assim, uma obra com wabi-sabi não pode ser copiada, pois o resultado estético é a consequência de algum acontecimento intangível.

Dando prosseguimento aos códices anteriores, o atual livro desenvolve-se, por um lado, na abordagem da transparência do papel, gerando composiçóes formadas a partir da sobreposição das páginas. Por outro, na valorização do processo de produção, em que alcançar um estado interior durante a realização tem reflexos no trabalho final.

Em relação à transparência das páginas, o códice atual é formado por uma folha horizontalmente longa, dobrada em forma de sanfona e costurada na lateral esquerda assim formando diversas pequenas páginas. No meio das dobras foram inseridos desenhos inacessiveis ao olhar, a não ser quando espreitados através dos vãos deixados pelo processo de dobra, abertos na parte superior e inferior; ainda assim, a visão direta é impossibilitada.

Como assunto visual, os desenhos podem ser divididos em dois grupos: naturezas mortas e tramas de pontos espalhados uniformemente na superfície da página. Ambos os grupos possuem em comum o fato de seguirem métodos semelhantes aos descritos nas artes clássicas japonesas; neles busco me concentrar durante o trabalho para assim me tornar interiormente sereno e atento ao momento em que realizo os desenhos - em outras palavras, me posicionando no momento presente, evitando pensamentos e divagaçóes. No primeiro grupo de desenhos, trabalhei com aquarela e pincel na pintura de naturezas mortas retratando diferentes vasos de plantas. Já no segundo, a trama de pontos constantes e regulares foi feita com nanquim e pena de bambu, mantendo sempre a mesma distância entre os pontos sem o uso de instrumentos técnicos. Naturalmente, é impossível se alcançar a completa exatidão. As variações tiveram a finalidade de me permitir notar e retomar a concentração perdida durante a feitura de ambos os conjuntos de desenhos, seja nos deslocamentos na representação da natureza morta observada, seja na imprecisão da malha de pontos. 
Do conjunto de páginas resultaram composiçôes com amplos espaços em branco mantidos propositalmente. Esses são preenchidos por vultos de outras composições insinuadas com a sobreposição das demais folhas. Algumas manchas se tornam nítidas logo ao virar a página; outras variam dependendo da luz e da maneira pela qual o conjunto de páginas é folheado ou segurado. Entre revelaçóes e esvanecimentos, os desenhos ganham profundidade com a neblina formada na parcial translucidez do papel. 



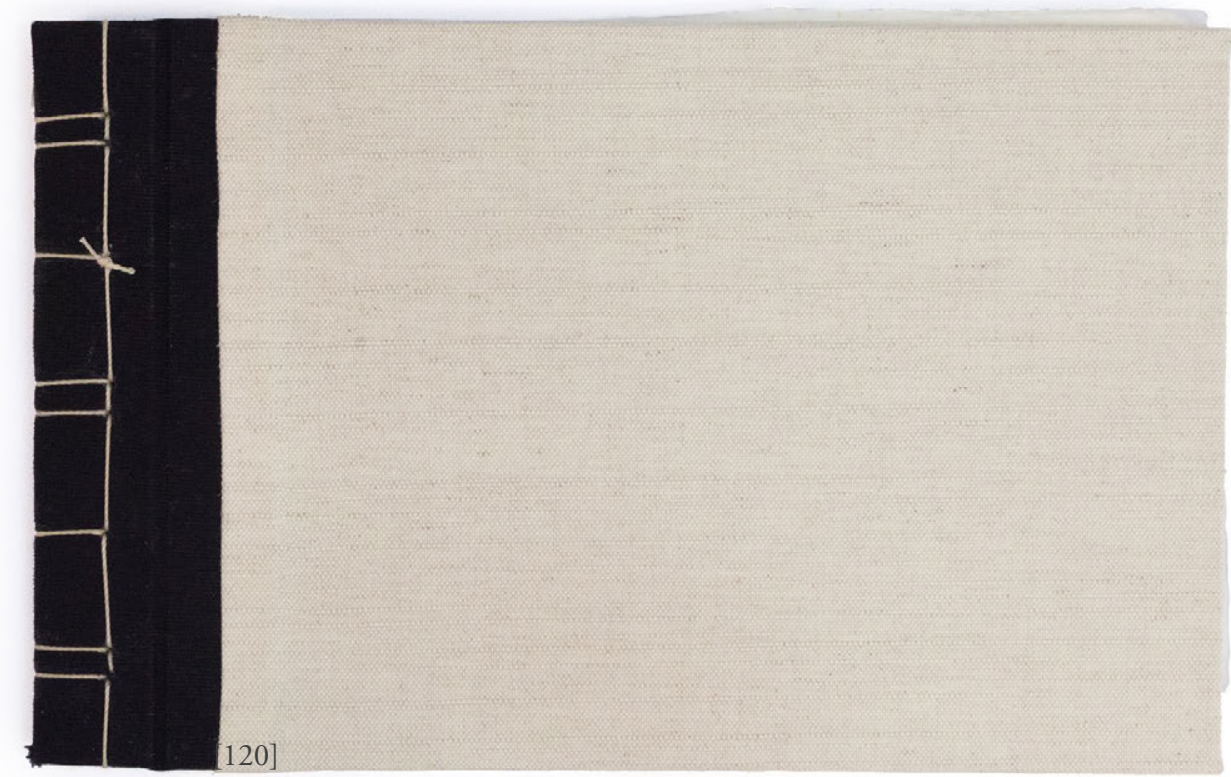

CÓDICE N.6

Técnica mista (papel de arroz, papel de restauro, tecido, linha encerada, aquarela, nanquim).

$27,7 \times 18,5 \mathrm{~cm}$ (fechado)

$52,3 \times 18,5 \mathrm{~cm}$ (aberto)

2016

(Ver DVD anexo) 


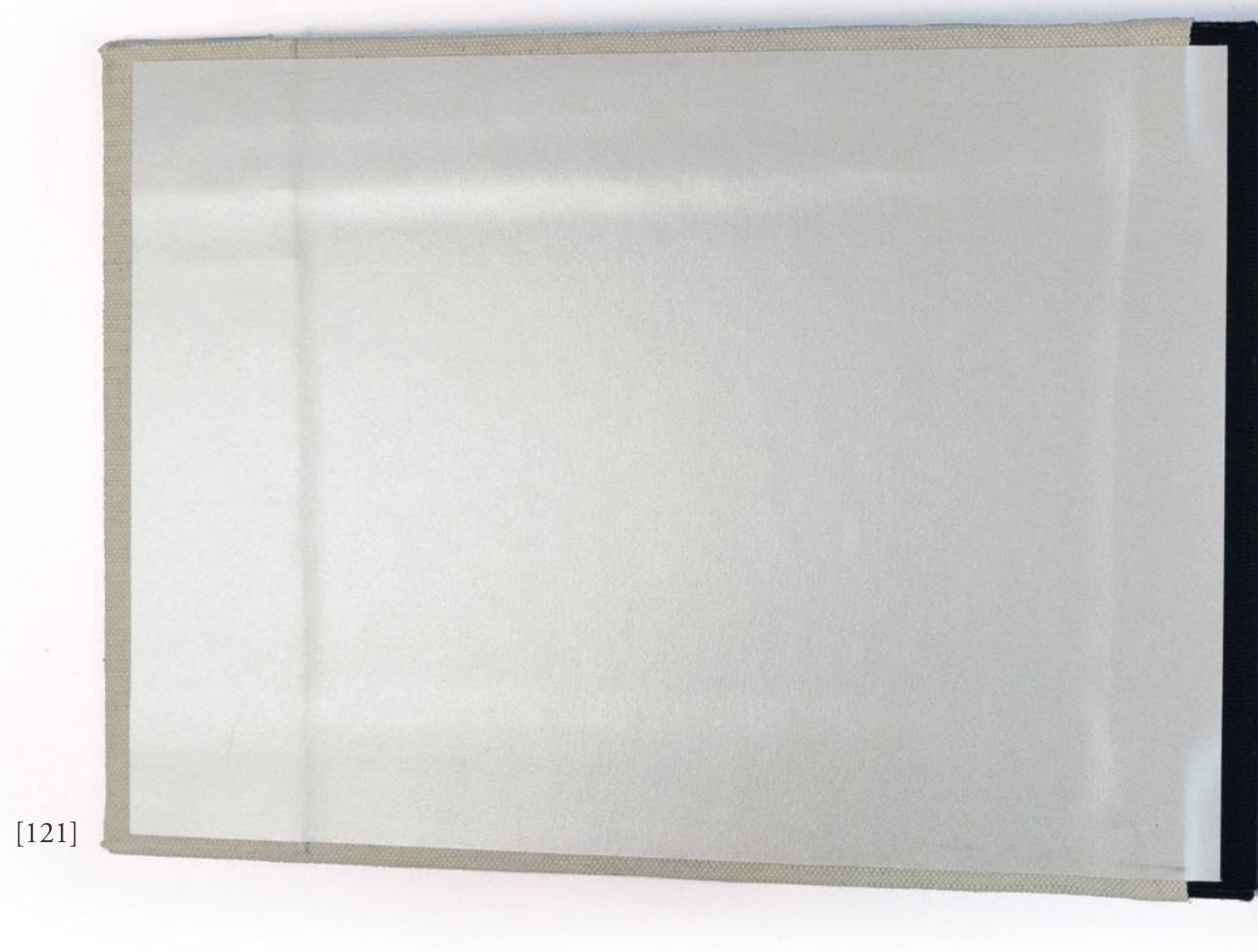

[122]

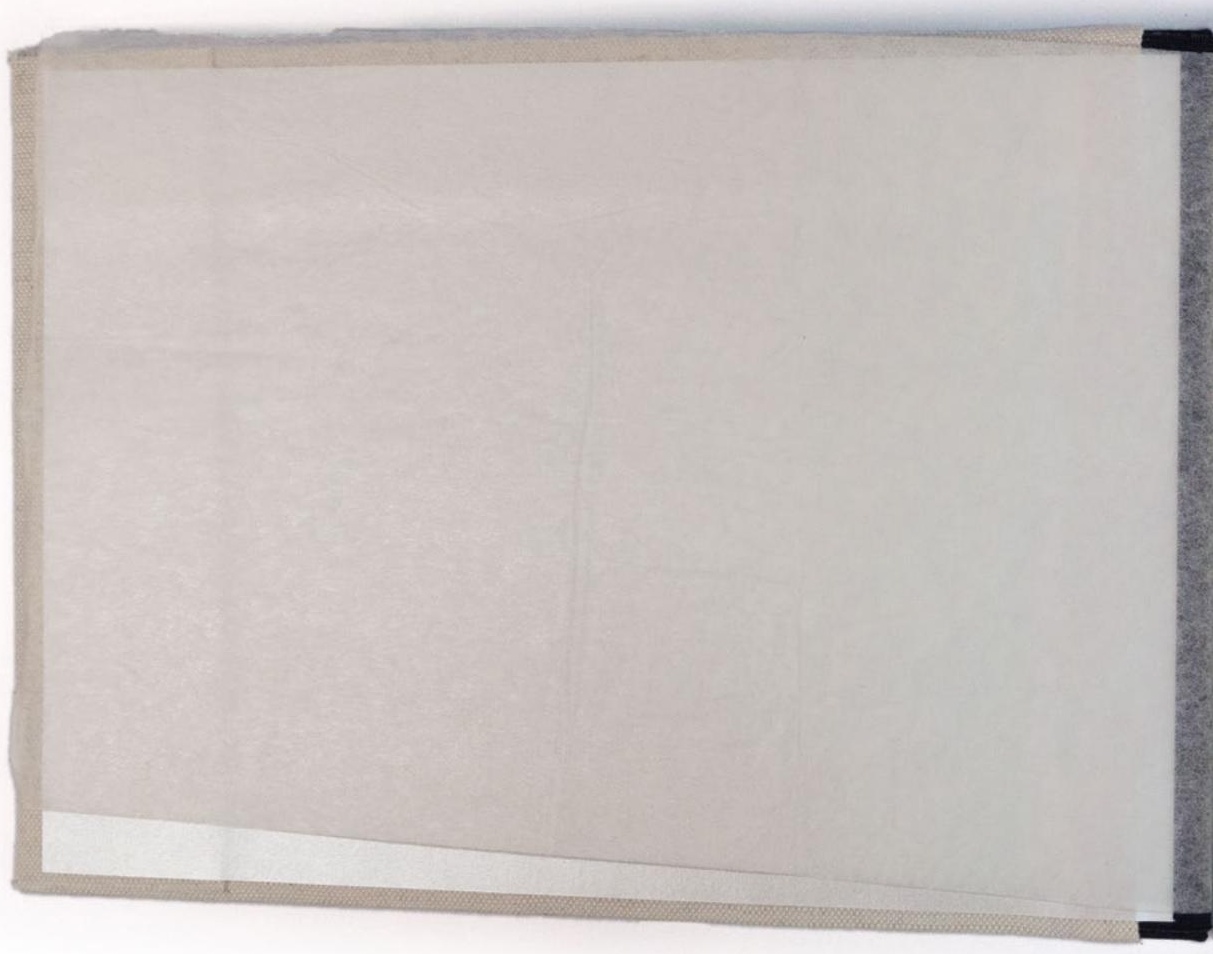



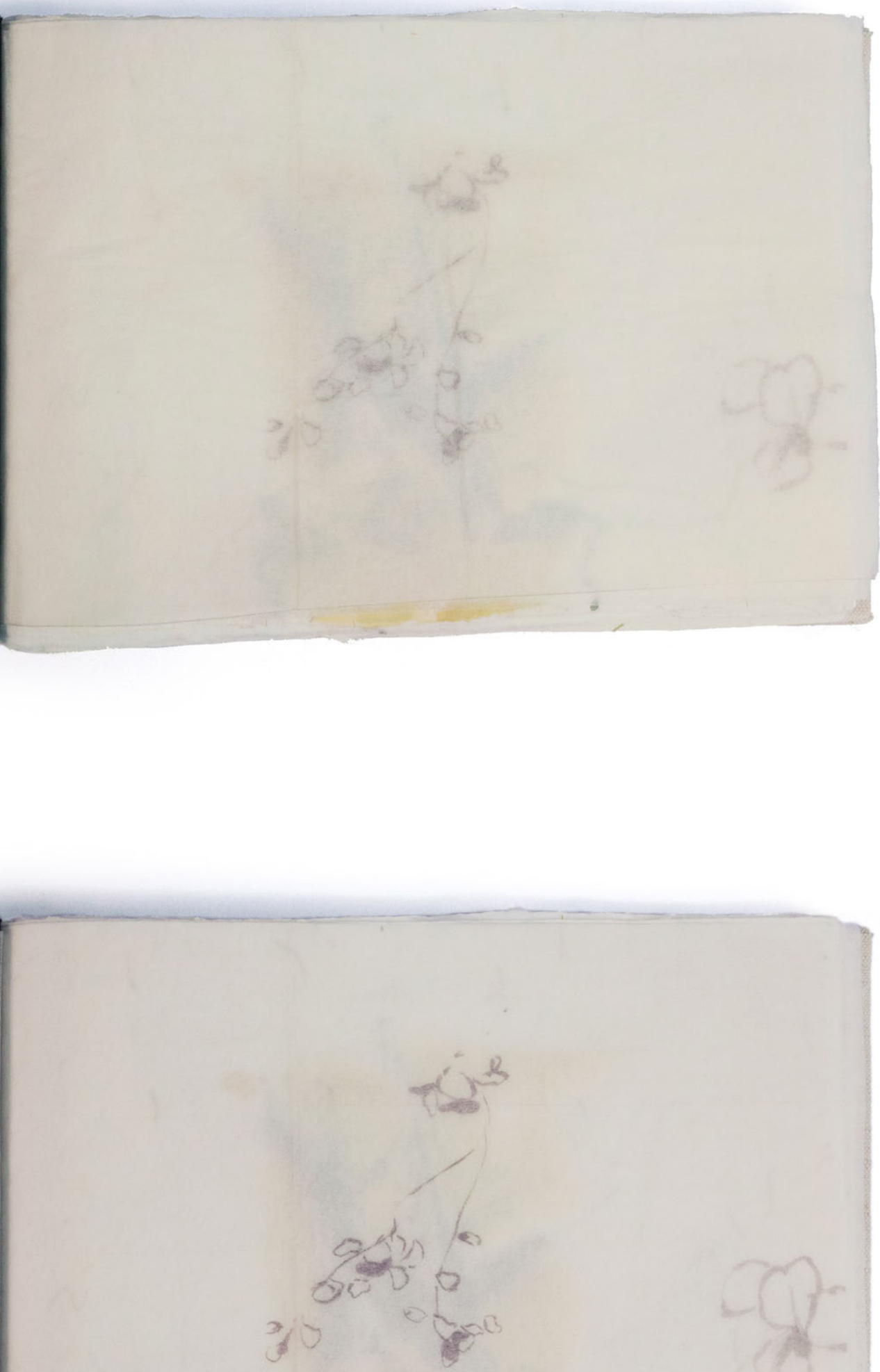


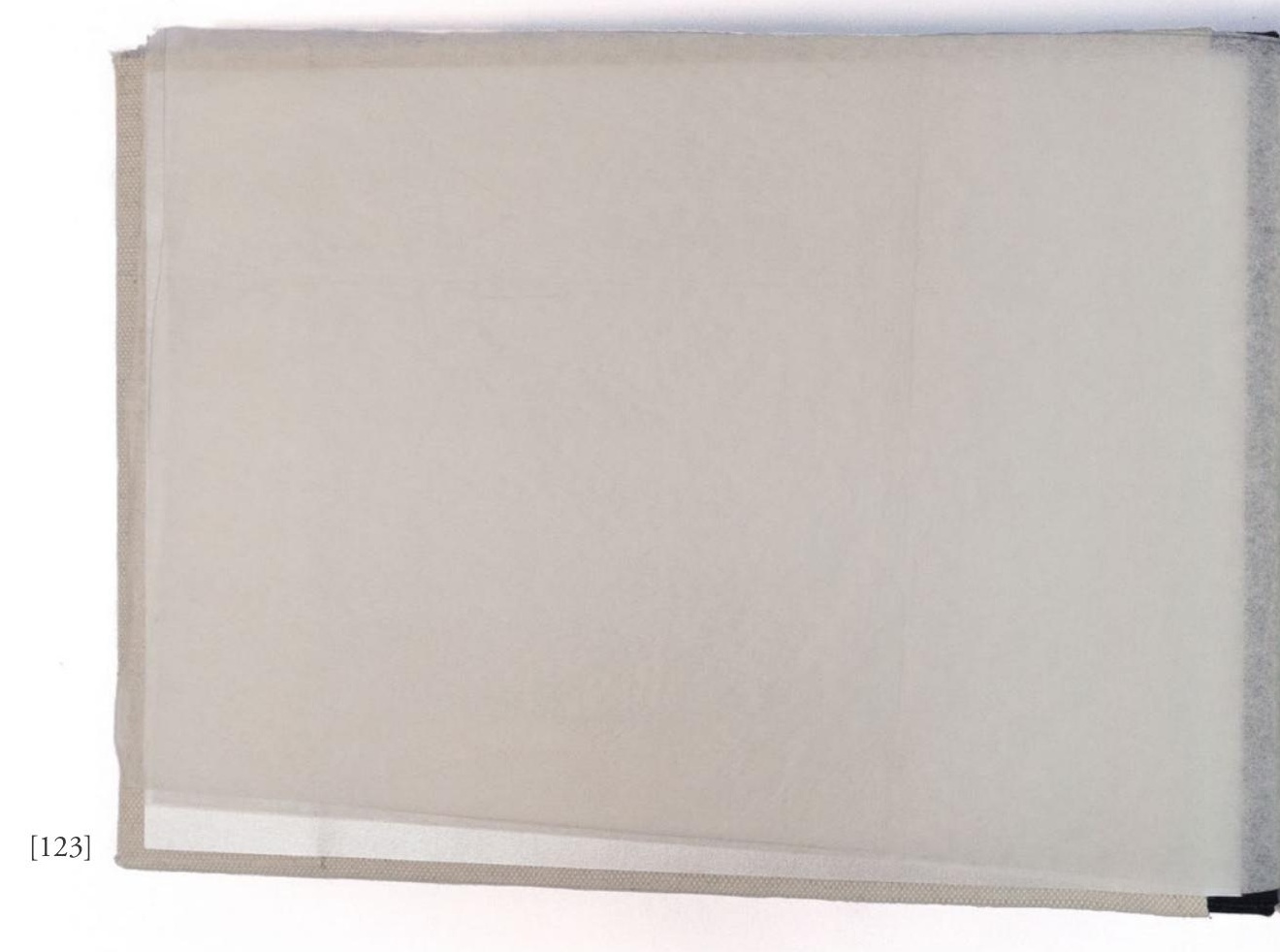

[123]

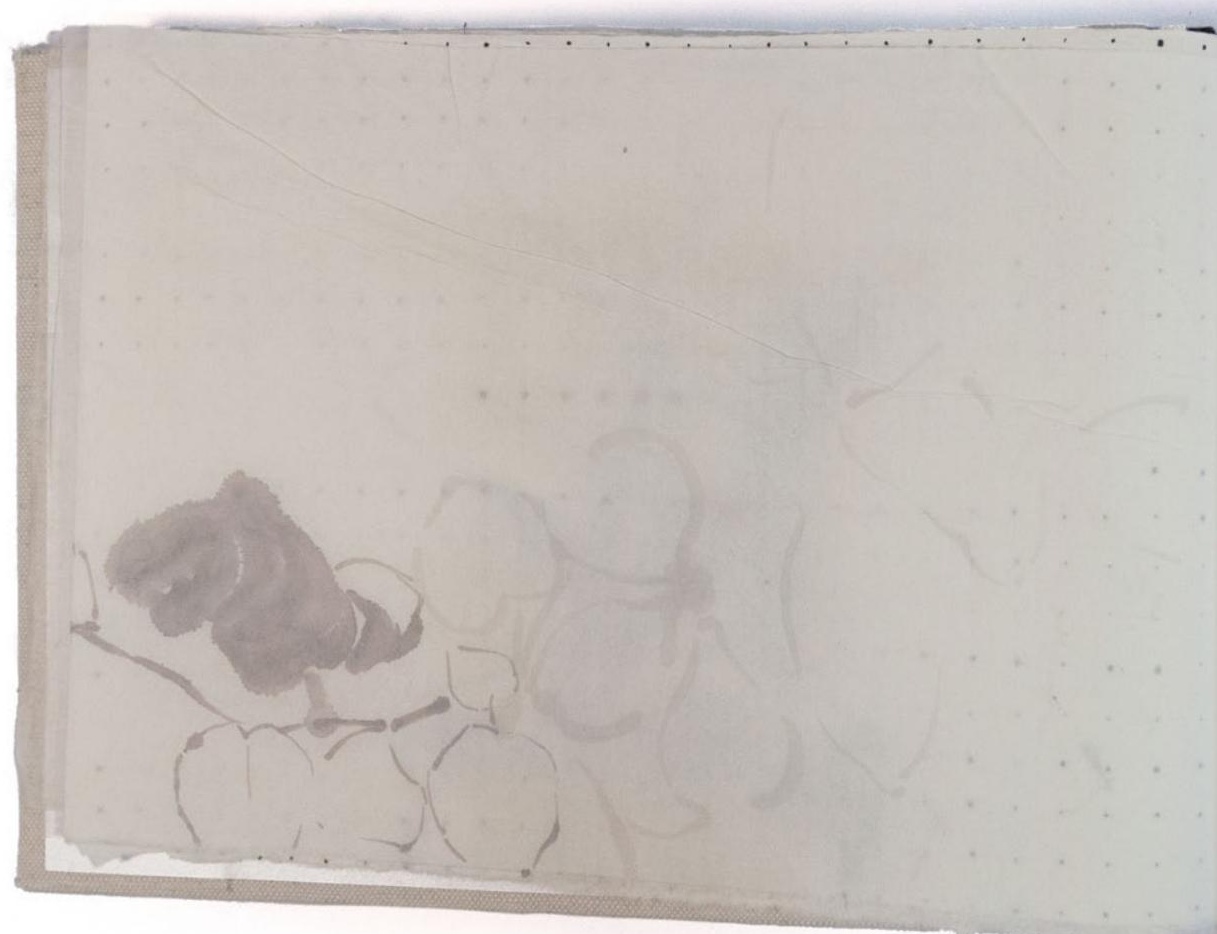

[124] 

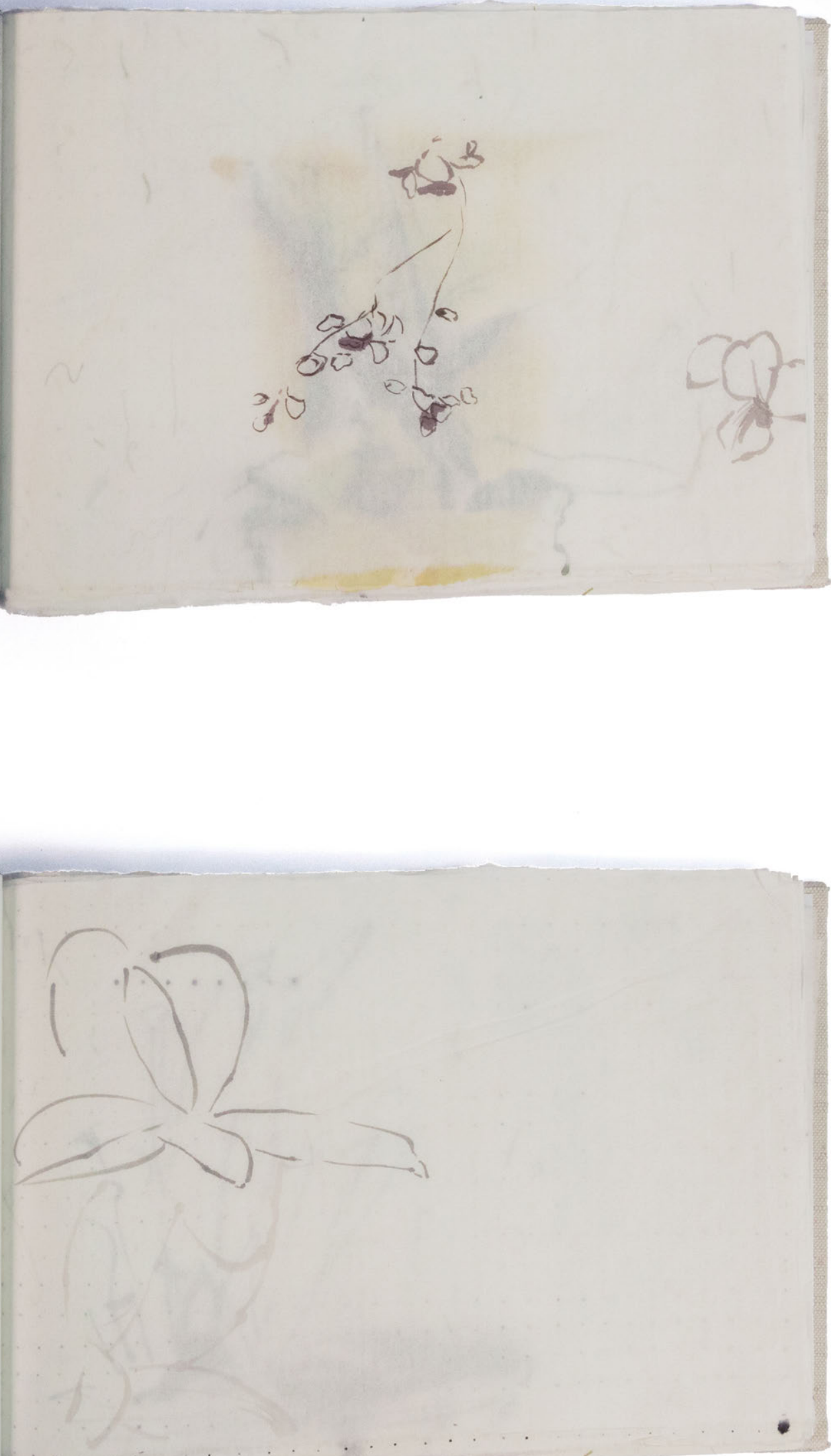

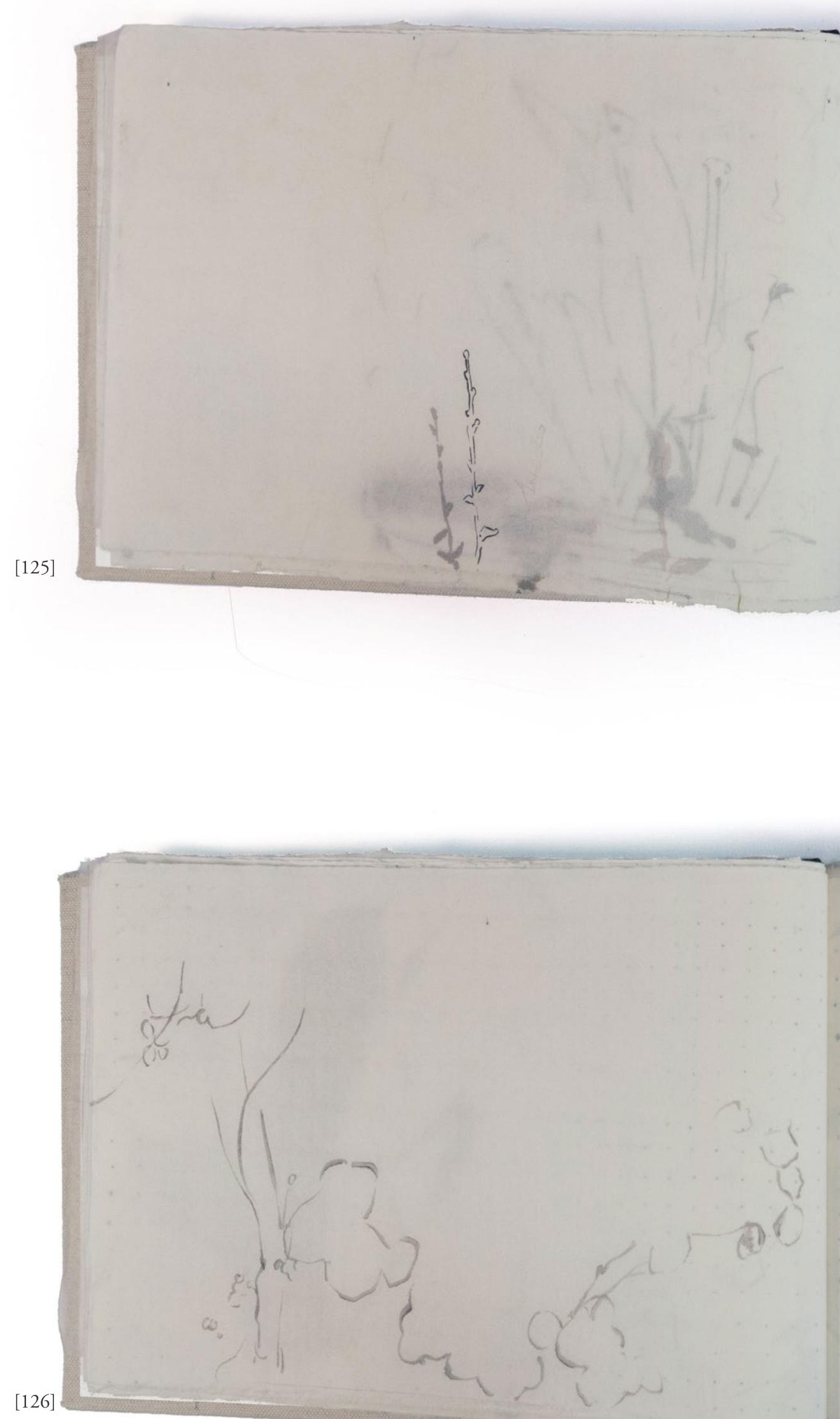

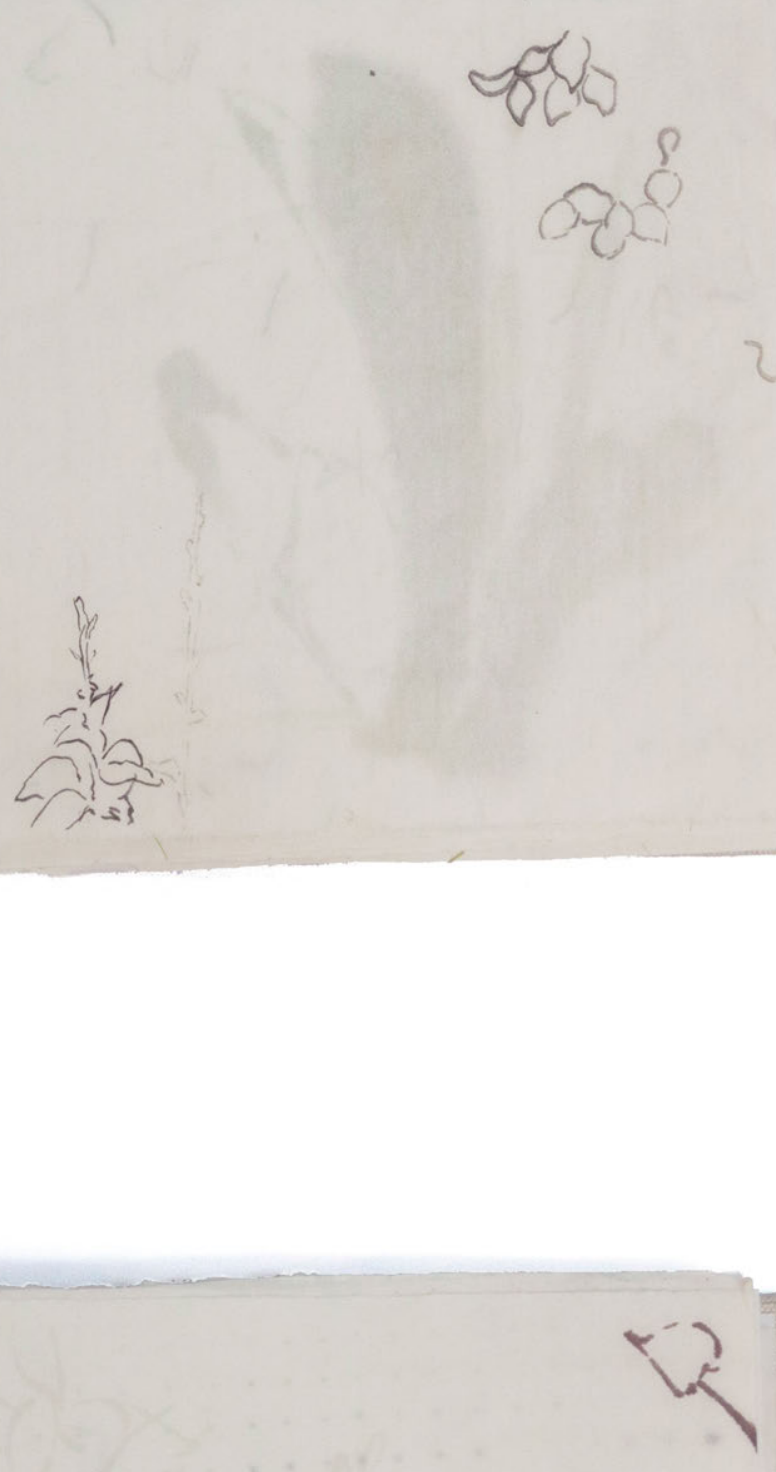

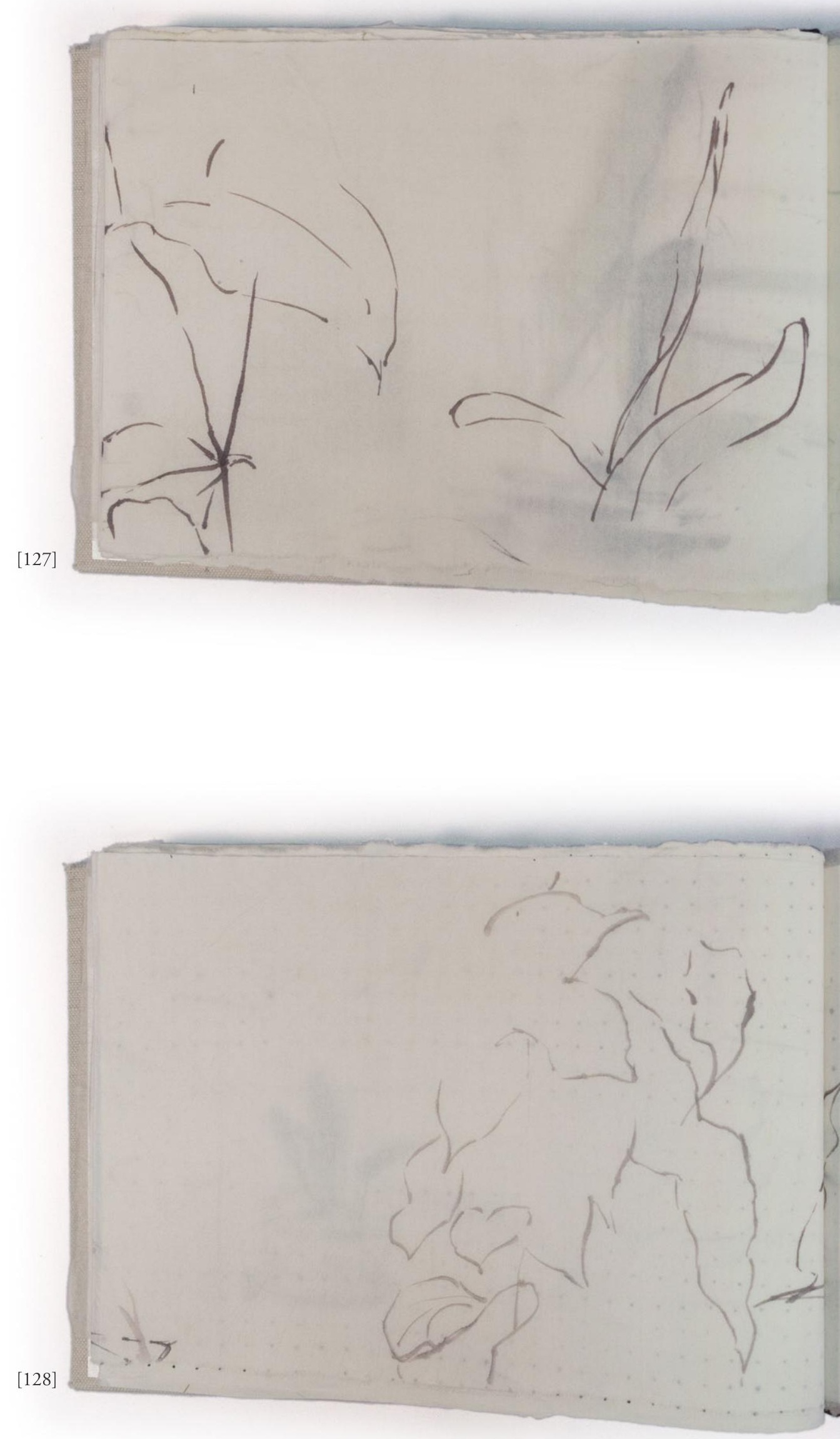

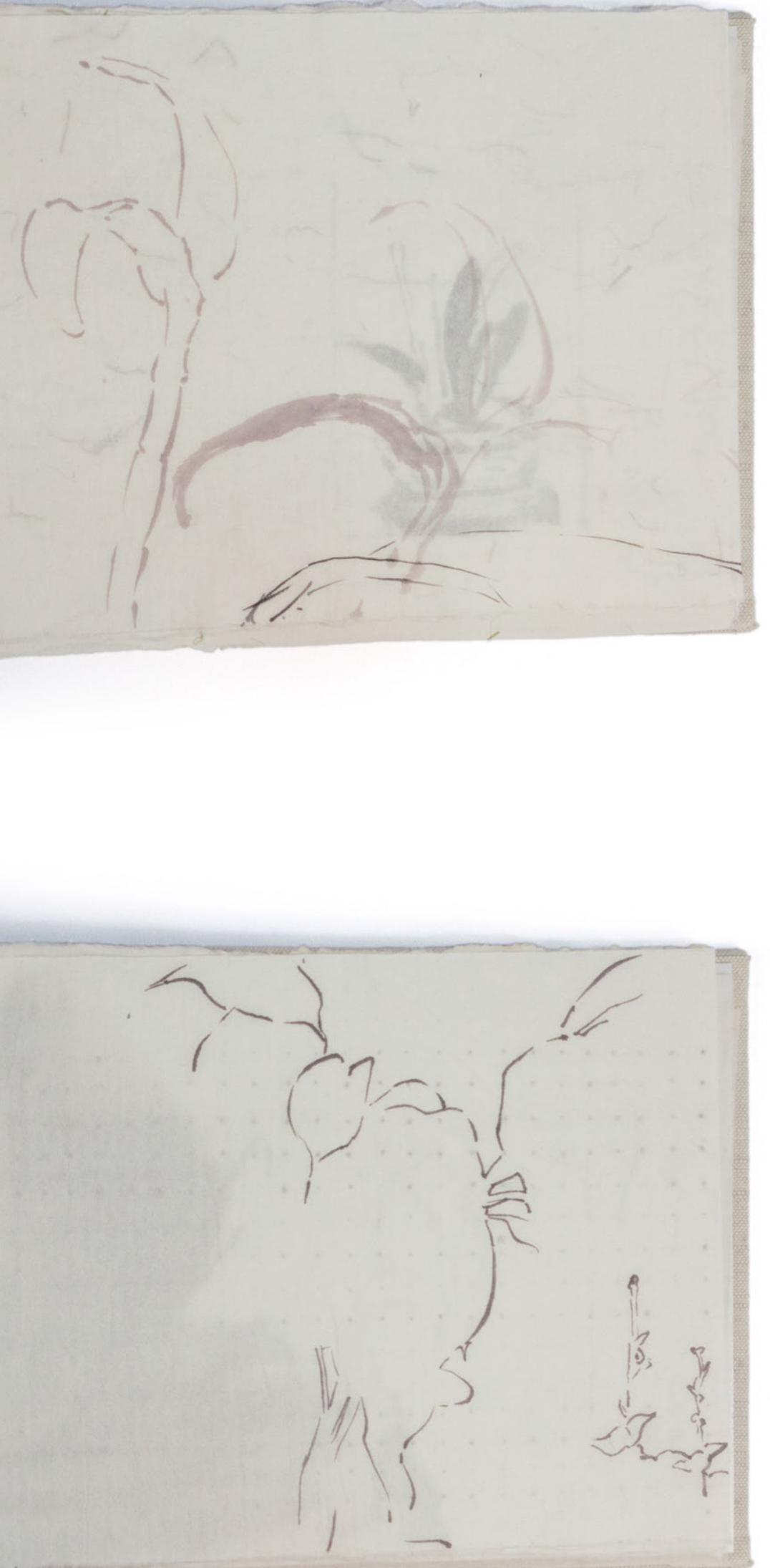


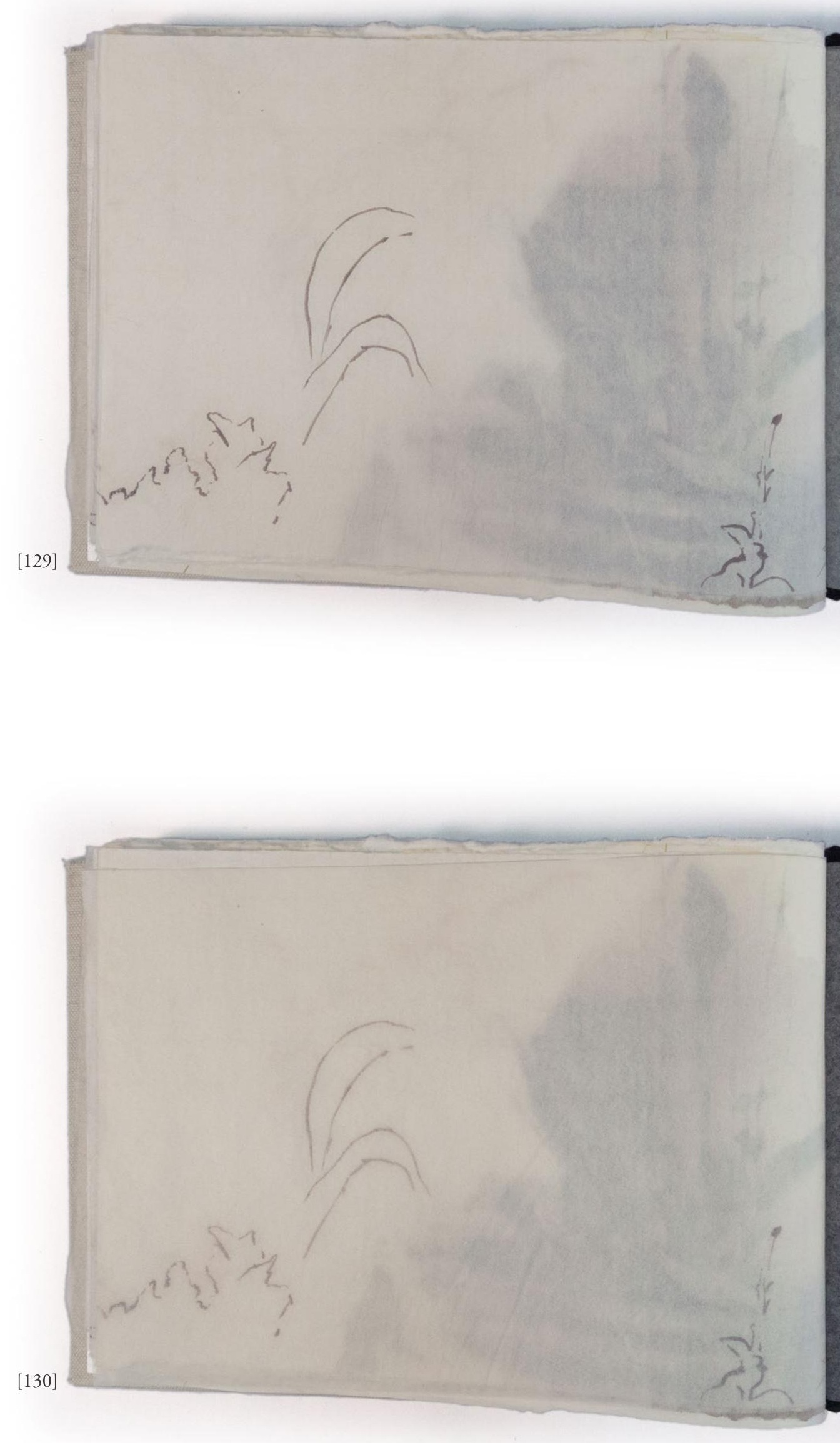




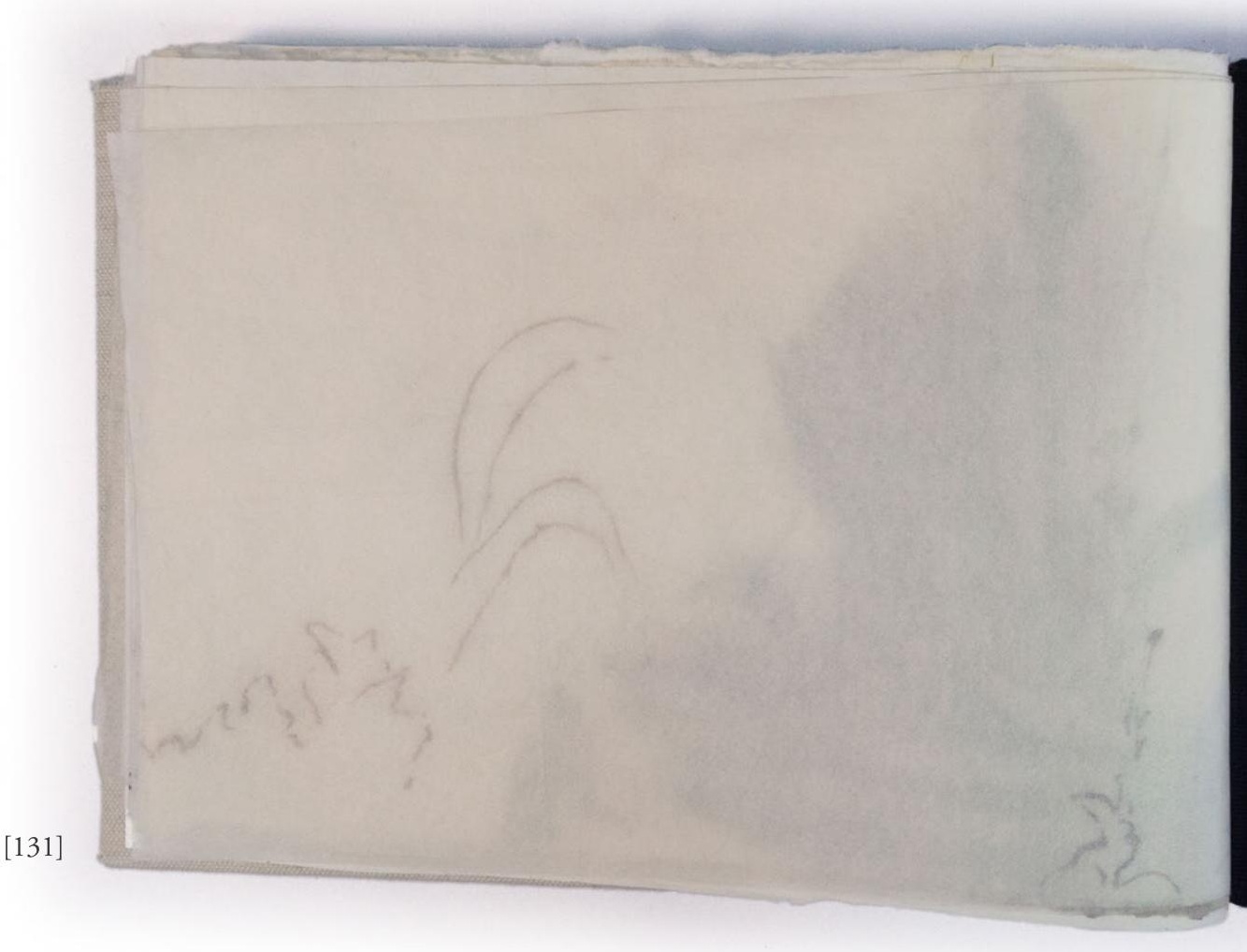




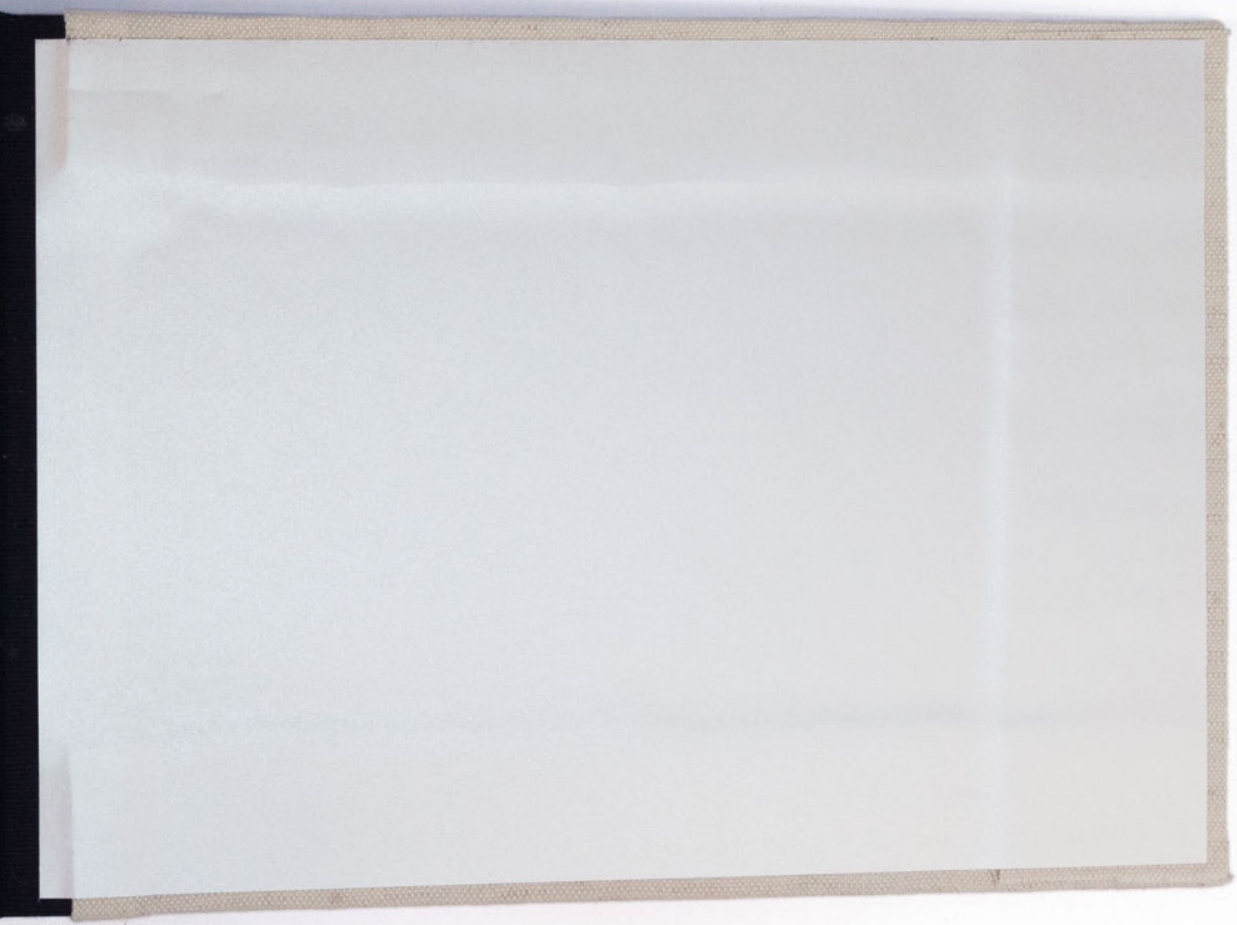



Suas palavras me causavam um sentimento como que de tristeza e eu não sabia o que responder, pois a verdade era que quando estava falando com ele - e sem dúvida o mesmo se passava com os outros - não me era possivel sentir essa felicidade que em compensação sentia quando estava só, sem companhia alguma. Porque naqueles momentos em que não havia ninguém a meu lado, sentia às vezes afluir do fundo de meu ser alguma impressão daquelas que me causavam um delicioso bem-estar. Mas quando estava com alguém, quando me punha a falar com um amigo, meu espirito dava meia-volta, de modo que meus pensamentos se dirigiam já a meu interlocutor e não a mim, e quando seguiam essa ordem inversa, deixavam de causar-me qualquer prazer.

Proust, Marcel. Em Busca do Tempo Perdido : ̇̀ sombra das raparigas em flor, 374-375. 





\section{CÓDICE N.7}

$I X$

Para entrar em estado de árvore é preciso partir de

um torpor animal de lagarto às três horas da tarde, no

mês de agosto.

Em dois anos a inércia e o mato vão crescer em

nossa boca.

Sofreremos alguma decomposiçāo lírica até o mato

sair na voz.

Hoje eu desenho o cheiro das árvores. ${ }^{56}$

O sétimo códice completa o ciclo desenvolvido durante a pesquisa e, assim como os demais livros, pode ser considerado o desdobramento natural dos códices que o precederam. Ele é o aprofundamento do método já empregado especialmente no Códice n.6. Mais rigoroso e complexo, o desenvolvimento das questôes anteriormente levantadas foi possibilitado e estimulado por meio

${ }^{56}$ Manoel de Barros, Biblioteca Manoel de Barros : O livro das ignoranças (São Paulo: LeYa, 2013), 11. 
do acesso a uma residência artística ocorrida durante o mês de agosto. Do dia 11 ao 20 de agosto de 2016, participei da residência artística EAV Parque Lage - Residência São João, ocorrida na Fazenda São João em São José do Vale do Rio Preto - RJ, período no qual paralelamente ocorreram as Olimpíadas Rio 2016. Ao contrário dos jogos da capital, a Olimpíada com a maior conectividade da história, ${ }^{57} \mathrm{o}$ espaço da fazenda era completamente isolado em meio aos morros da serra carioca, sem acesso à internet ou ao telefone.

Tendo em mente as ideias apresentadas no capítulo anterior em relação à rotina de trabalho dos praticantes do ikebana, para quem a prática se estende ao longo dos demais acontecimentos do dia, ${ }^{58}$ ou em relaçáo aos mestres da cerimônia do chá ao levarem o ideal perseguido durante a cerimônia para suas demais atividades cotidianas - na escolha do corte e cor das roupas, no andar ou em qualquer outra ação feita ao longo do dia ${ }^{59}-$, me propus, por oito dias, exceto na chegada e partida da fazenda, a acordar às $6 \mathrm{~h}$, meditar 20 minutos, tomar banho gelado e sair para desenhar. Após uma breve caminhada pela fazenda, assentava em meio à vegetação ou nas estradas de terra vazias; comigo, apenas uma prancheta, um pano, um vidro de nanquim e um estilete. Por uma a uma hora e meia, sozinho, me sentava para fazer desenhos de observação. Antes de efetivamente começar a riscar, em cada dia recolhia um graveto encontrado no chão para afia-lo e utiliza-lo como caneta e, uma vez terminados os desenhos, devolvê-lo à natureza.

\footnotetext{
${ }^{57}$ A conectividade das Olímpiadas Rio 2016 é comentada na matéria Sabrina Craide, "Olimpíada do Rio terá uso de internet quatro vezes maior que Londres", Portal de notícias, EBC Agência Brasil, (31 de julho de 2016), http://agenciabrasil.ebc.com.br/ rio-2016/noticia/2016-07/olimpiada-do-rio-tera-uso-de-internet-quatro-vezes-maiorque-em-londres.

${ }^{58}$ Comentários sobre as atividades diárias do praticante em seu colhimento interno em Herrigel, O zen na arte da cerimônia das flores, 39.

${ }^{59}$ Descrição da expressão artística dos mestres do chá em Okakura, O livro do chá, 107.
} 
A escolha por acordar antes dos outros residentes para produzir o livro (o café da manhã era servido às 8 horas, horário quando os demais participantes costumavam se levantar) deve-se ao fato de nesse momento do dia o vazio na fazenda ser ainda mais intenso. Normalmente, a qualquer hora do dia, se tornava cada vez menos provável encontrar outras pessoas ao se afastar da casa principal, quer fosse no campo, quer fosse nas estradas de terra. Ainda assim, a certeza de haver poucas pessoas levantadas logo cedo contribuiu para que não encontrasse ninguém para conversar durante minha caminhada, evitando me distrair da concentração almejada para a prática do desenho. Durante a manhã, os únicos despertos eram os funcionários da fazenda, com quem cruzava diariamente nas estradas de terra, com breves trocas de cumprimentos. Ademais, os ritmos desse local cada vez se mostraram mais distintos em relação aos vividos em São Paulo; nos encontros, o iminente porvir já era anunciado momentos antes com o gradual aumento dos ruídos vindos do motor do carro, moto ou trator, ou ao notar a nuvem de terra levantada com o passar de rodas. Náo havia surpresa no acontecimento, durante o próprio desenhar eu já notava a aproximação lenta e constante de alguém, não acarretando interrupçóes bruscas e imprevistas na concentração dedicada à prática. Tomando contornos de um ritual, o exercício rigoroso e regular da rotina serviu como meio de me encaminhar para o estado de espírito almejado durante a produção das páginas do livro.

Os desenhos, feitos em sua maioria em diferentes tipos de papel de arroz previamente recortados, foram posteriormente organizados como livro. A única exceção em relação ao papel são as pequenas folhas de papel pergaminato, nelas os desenhos foram realizados com base na observação de almofadas, bordadas à mão, existentes na casa principal, onde fomos hospedados.

O que motiva um gesto do pintor nunca pode ser apenas a perspectiva ou apenas a geometria, as leis da decomposição das cores ou outro conhecimento qualquer. Para todos os gestos que aos poucos fazem um quadro, há um único motivo, é a paisagem em sua 
totalidade e em sua plenitude absoluta - que justamente Cézanne chamava de 'motivo'. (...) Ele 'germinava' com a paisagem. Esquecida toda ciência, tratava-se de recuperar por meio dessas ciências, a constituição da paisagem como organismo latente. ${ }^{60}$

Já notado por Paul Valéry no ensaio "Ver e Traçar", ${ }^{61}$ ao desenhar vemos de maneira diversa daquela do cotidiano. Com um lápis em mãos, os olhos se aguçam para os mínimos detalhes do objeto pousado à frente. Me fascinei, provavelmente durante o processo de todos os desenhos feitos durante a residência, ao notar detalhes, proporçôes, sobreposiçôes e sutilezas nos objetos retratados. O próprio ato de riscar me levou a perceber minúcias até então ignoradas, sutilezas corriqueiras que facilmente passam sem dar sinal de suas existências. Particularidades com as quais nos deparamos a todo instante, se mostrando presentes apenas ao pararmos para desenhá-las. Nesse momento, a infinita complexidade da natureza aparece latente. Durante o processo, fui cada vez mais levado a escolher representar pequenos elementos próximos: folhas a minha frente, a planta parada ao meu lado ou um conjunto de pedras e grama. A vantagem deles é o fato de nesses breves conjuntos não me ser exigido demasiado movimento dos olhos para intercalar a observação entre o objeto visto e a representação tomando forma no papel. Ademais, a proximidade permitiu notar com maior cuidado os detalhes da forma representada. Durante o traçar não me preocupei em compor, apenas risquei os objetos, acompanhando-os com o olhar, até ser interrompido ou perder a concentração; ou então quando as linhas representadas não coincidiam com a visão, em decorrência dos pequenos acúmulos de erro nas proporçôes ao longo do trabalho. Nesses momentos, interrompia o desenho, escolhia uma nova parte em branco em

\footnotetext{
${ }^{60}$ Maurice Meleau-Ponty, O olho e o espirito (Sáo Paulo: Cosac Naify, 2013), 136-137.

${ }^{61}$ Paul Valéry, Degas dança desenho, trad. Christina Murachco e Célia Euvaldo (São Paulo: Cosac Naify, 2012), 61-66.
} 

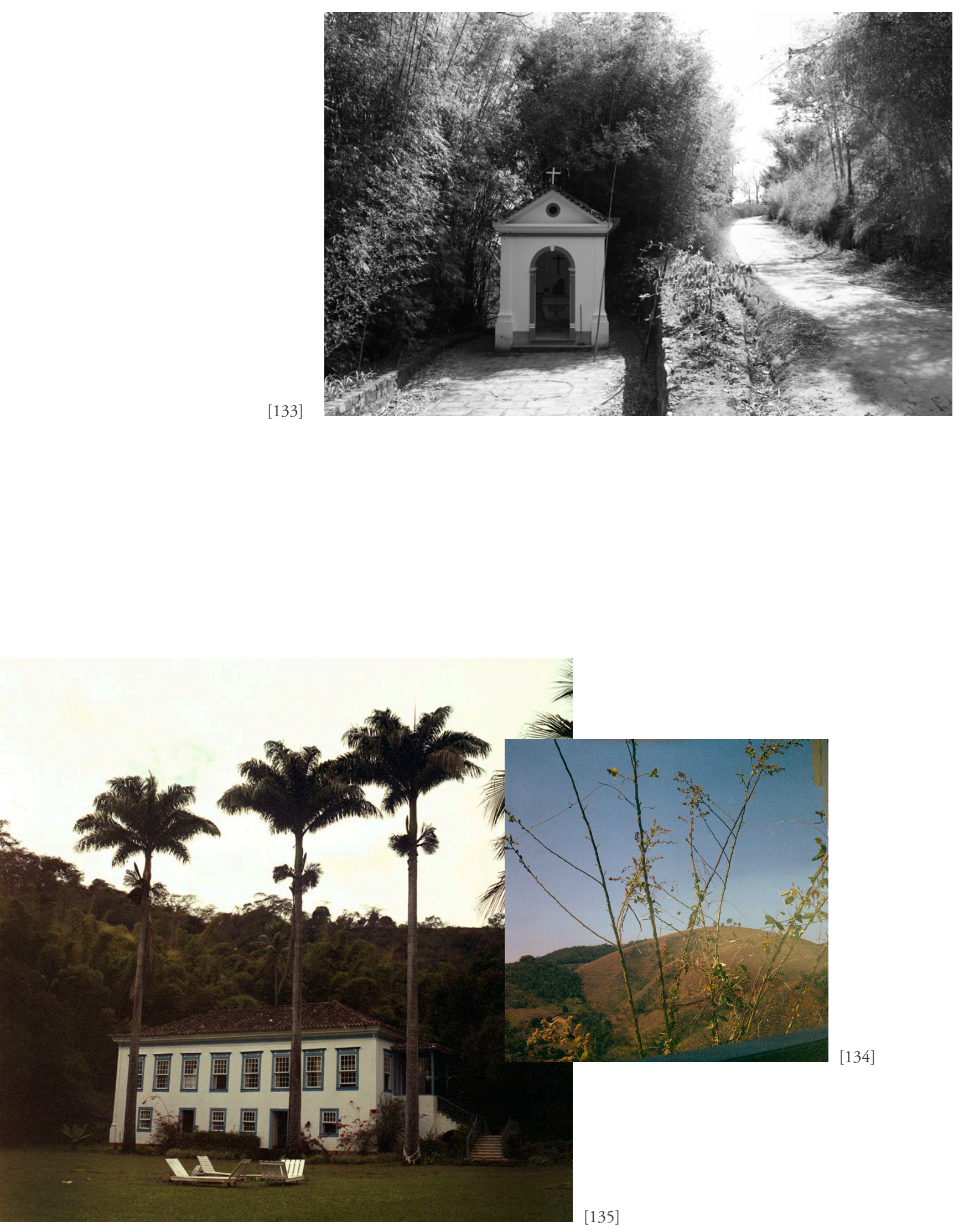


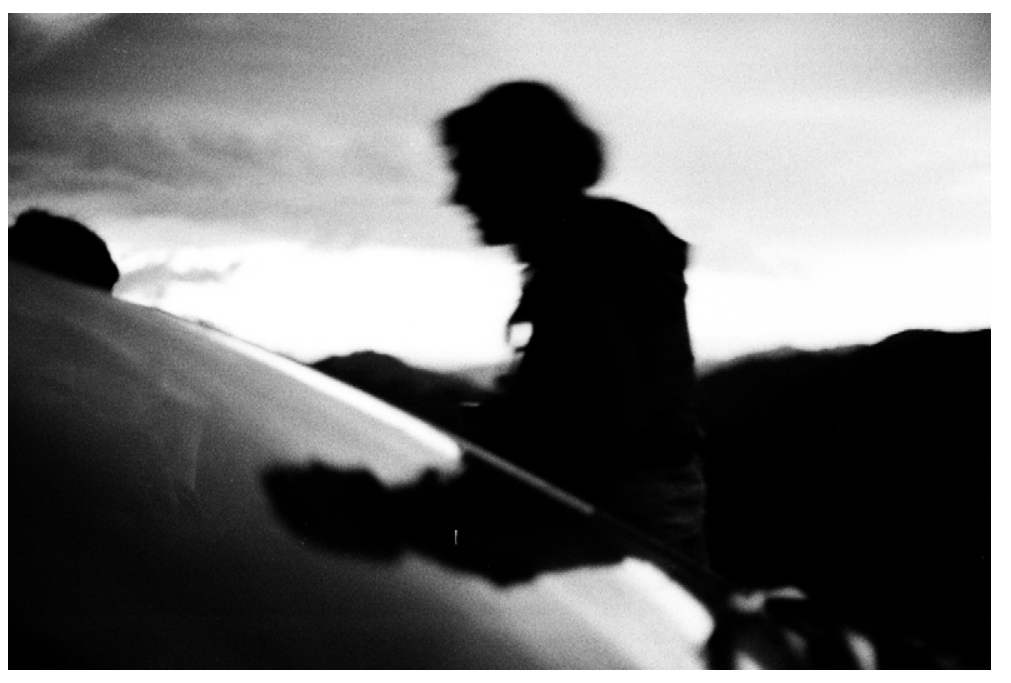

[137]

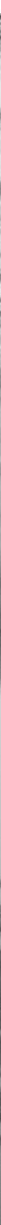


alguma das faces da folha, observava um novo ponto da paisagem e retomava o traçado. $\mathrm{O}$ único critério compositivo envolvido era a distribuição de desenhos nos dois lados da folha até o preenchimento de cerca de um terço de sua superfície. Ainda assim, a análise dos desenhos já feitos só acontecia nos intervalos entre as representaçôes, pois, durante a prática, o tamanho da superfície preenchida não fora colocado em pauta, eu apenas prosseguia o riscar até nova interrupção. Além das imagens de observação, há um outro tipo de grafismo presente nas páginas: sequências repetidas de pontos ou traços. Esses são, assim como no Códice n.4, um meio de me concentrar e retomar o estado de espírito almejado, com a diferença de que nesse caso não observava nada além da própria imagem em formação.

Seja em desenhos figurativos, feitos de observação, seja em elementos gráficos repetidos de maneira aparentemente mecânica, o processo de trabalho é fundamental na produção das páginas. Ele possui a finalidade de ser um instrumento para alcançar o tempo suspenso, ${ }^{62} \mathrm{em}$ uma dialética na qual estar em um estado de espírito específico faz o trabalho ser impregnado por essa temporalidade, e o próprio processo de trabalho encaminha à interioridade pretendida.

A composição final do códice, com a escolha da ordem das páginas, se deu, em parte, de antemáo, em meu cortar dos papéis no primeiro dia da residência, e, em parte, no intervalo entre os dias, quando sobreporus as páginas e analisarei as manchas formadas através da limitada translucidez das finas folhas. Explorando a gestualidade proporcionada durante a leitura e o subsequente manuseio do livro, nota-se que as páginas são de diferentes tamanhos, espessuras e dobras. A sobreposição de camadas de papel e a delicadeza das folhas em papel de arroz pedem em sua totalidade um manejo e cuidado especial por parte do leitor. A falta

\footnotetext{
${ }^{62}$ Comentários sobre o fato de na cerimônia do chá o praticante realizar movimentos repetitivos que o permitem se concentrar apenas em ser, em Koren, Wabi-sabi for artists, designers, poets \& philosophers, 35.
} 
de atenção no ato de ler o livro pode facilmente rasgar sua superfície ou deixar passar despercebida a importância dos vultos criados na sobreposição das páginas, com manchas a mudarem de forma a todo momento, no folhear e desdobrar do papel. 


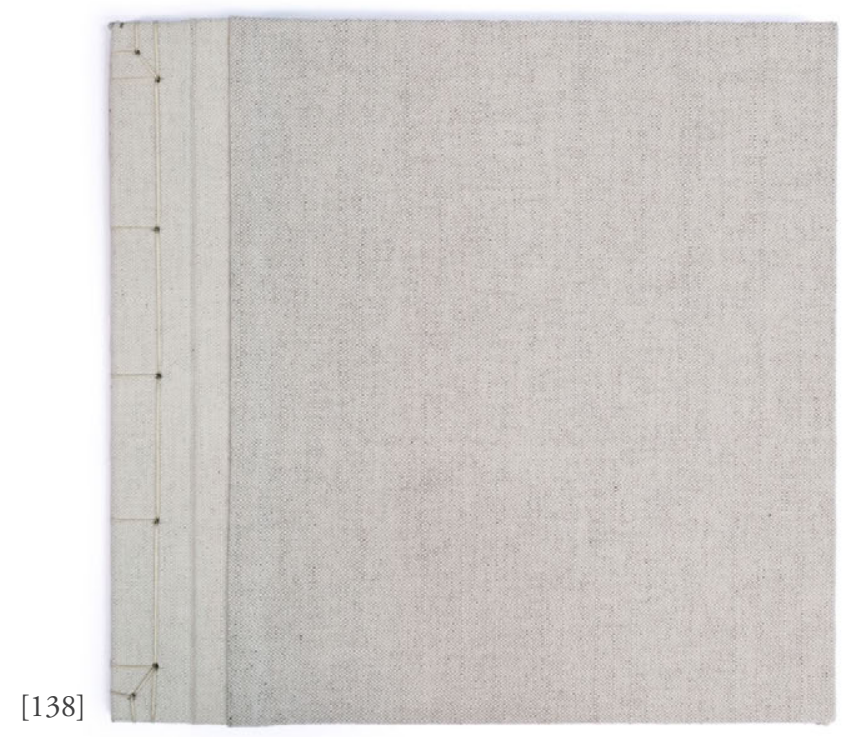

CÓDICE N.7

Técnica mista (papel de arroz, papel pergaminato, tecido, linha encerada, nanquim).

$26,4 \times 25,4 \mathrm{~cm}$ (fechado)

$47,6 \times 25,4 \mathrm{~cm}$ (aberto)

2016

(Ver DVD anexo) 

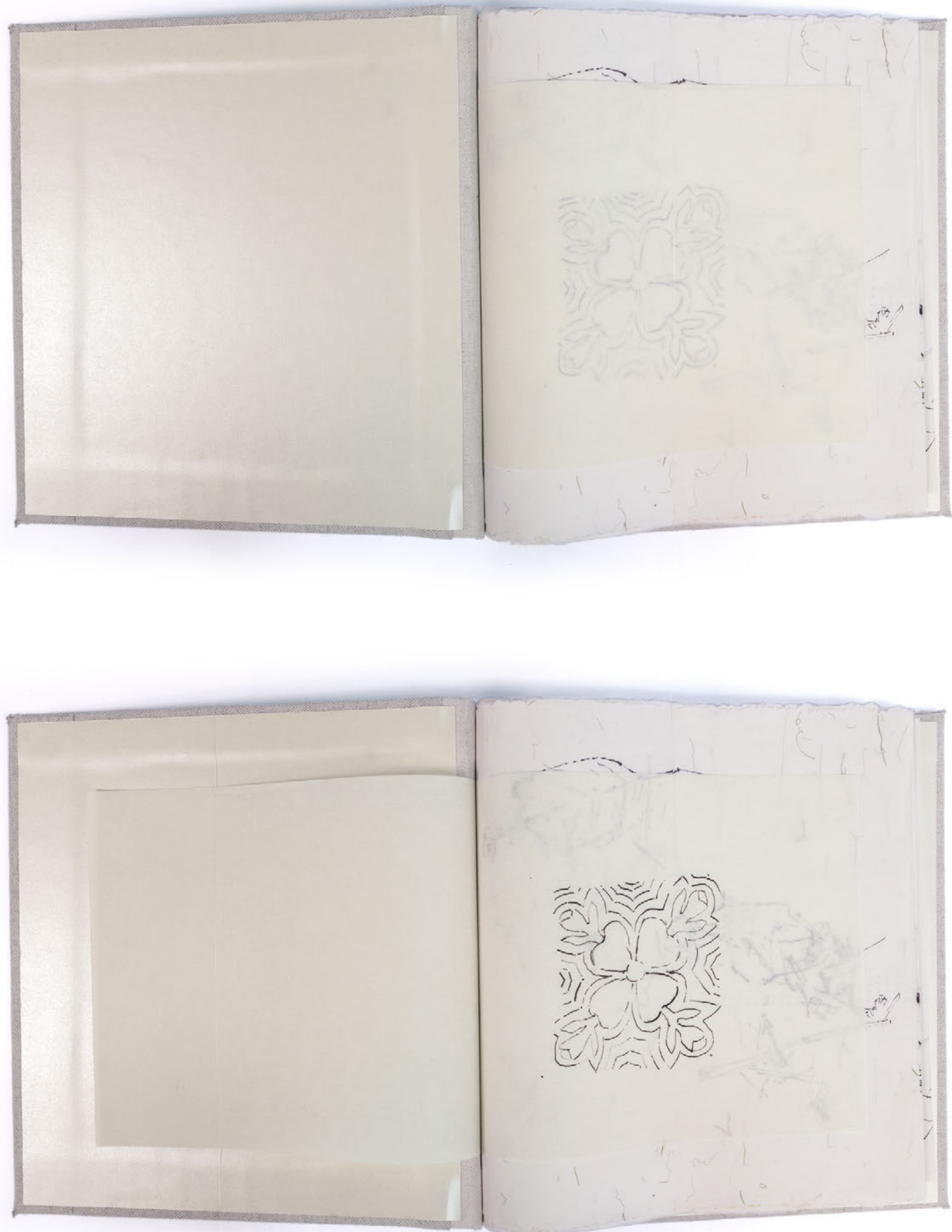

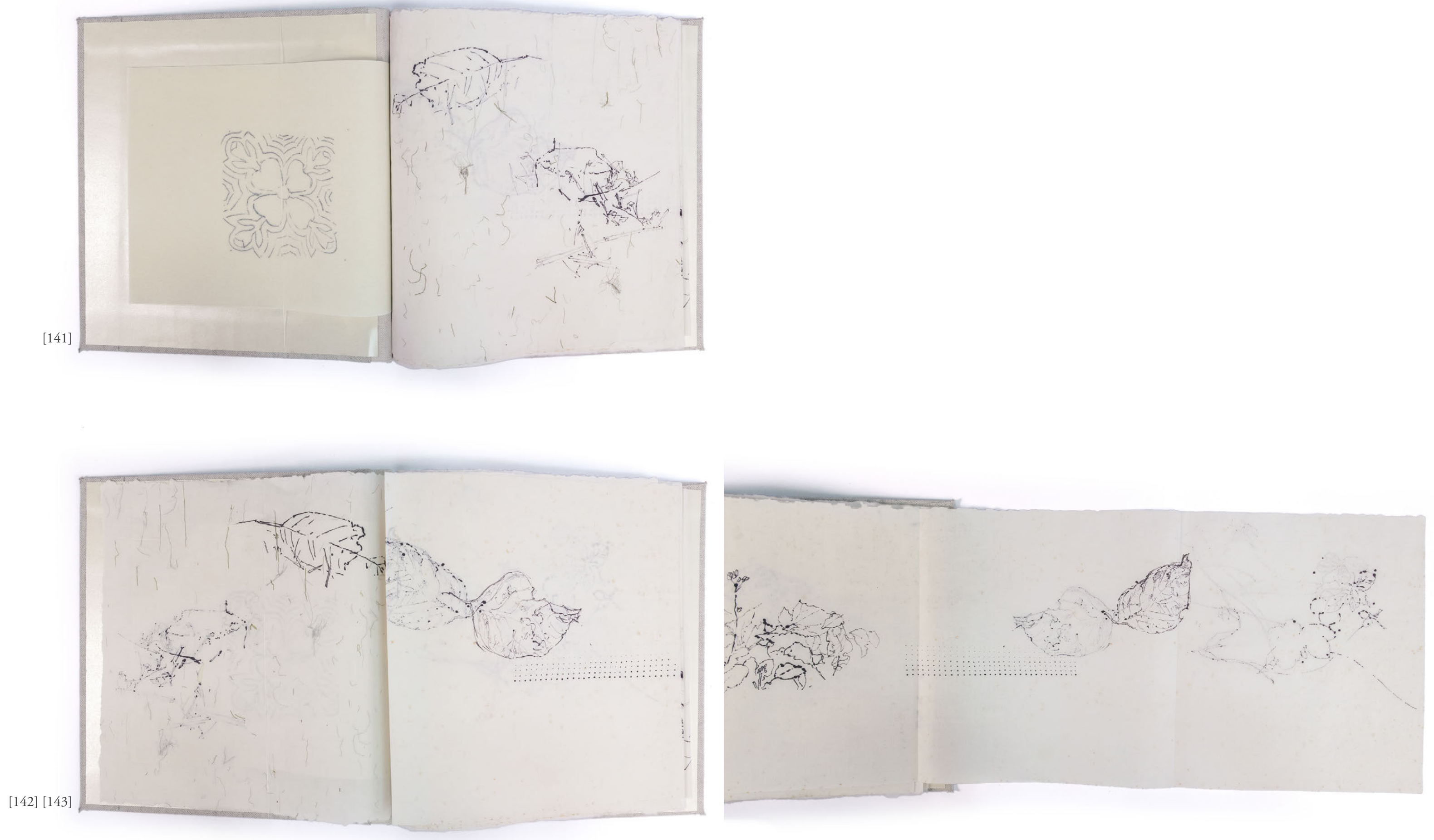

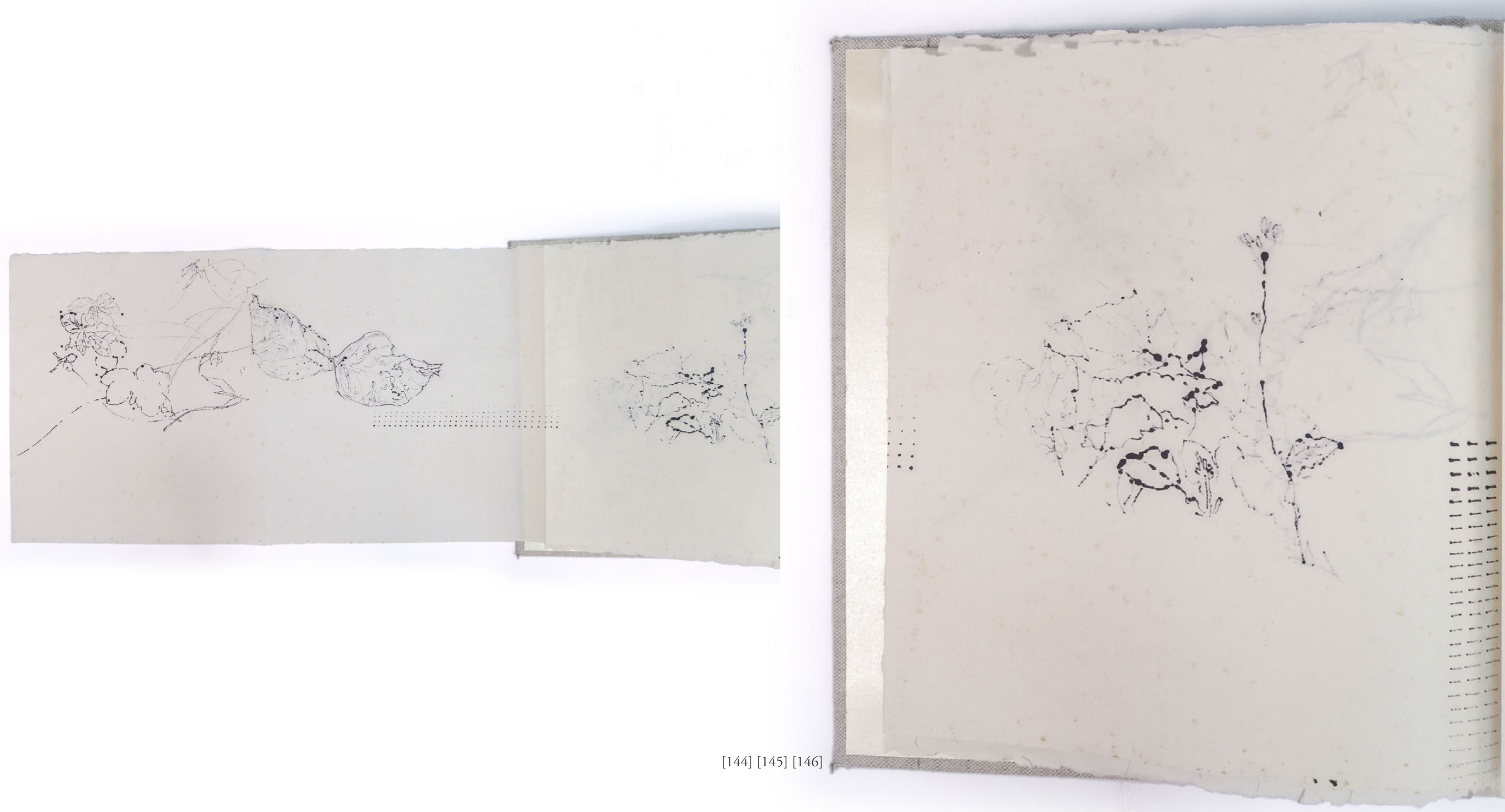

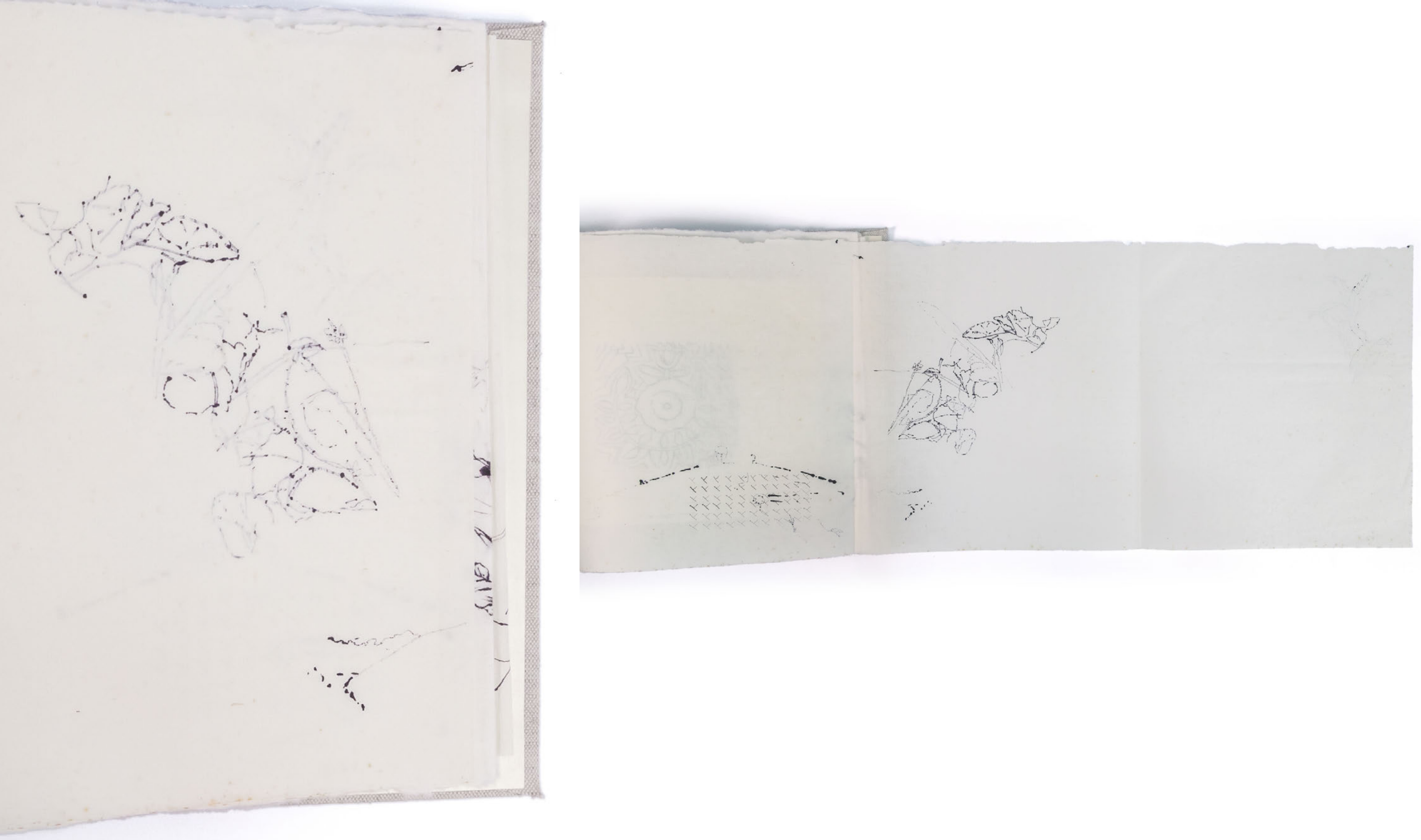

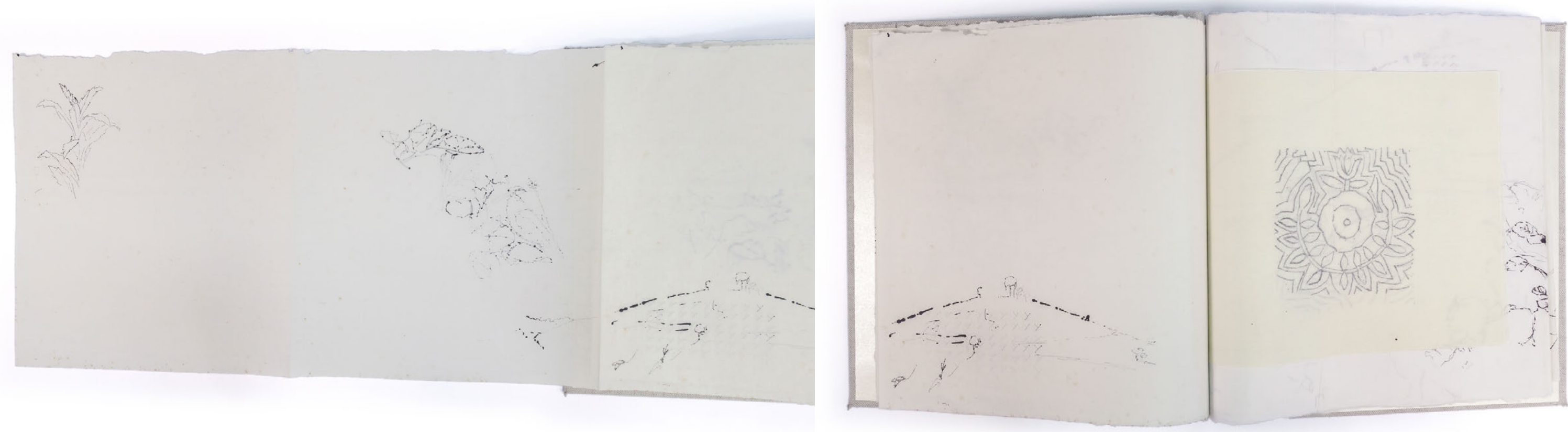

[147] [148]

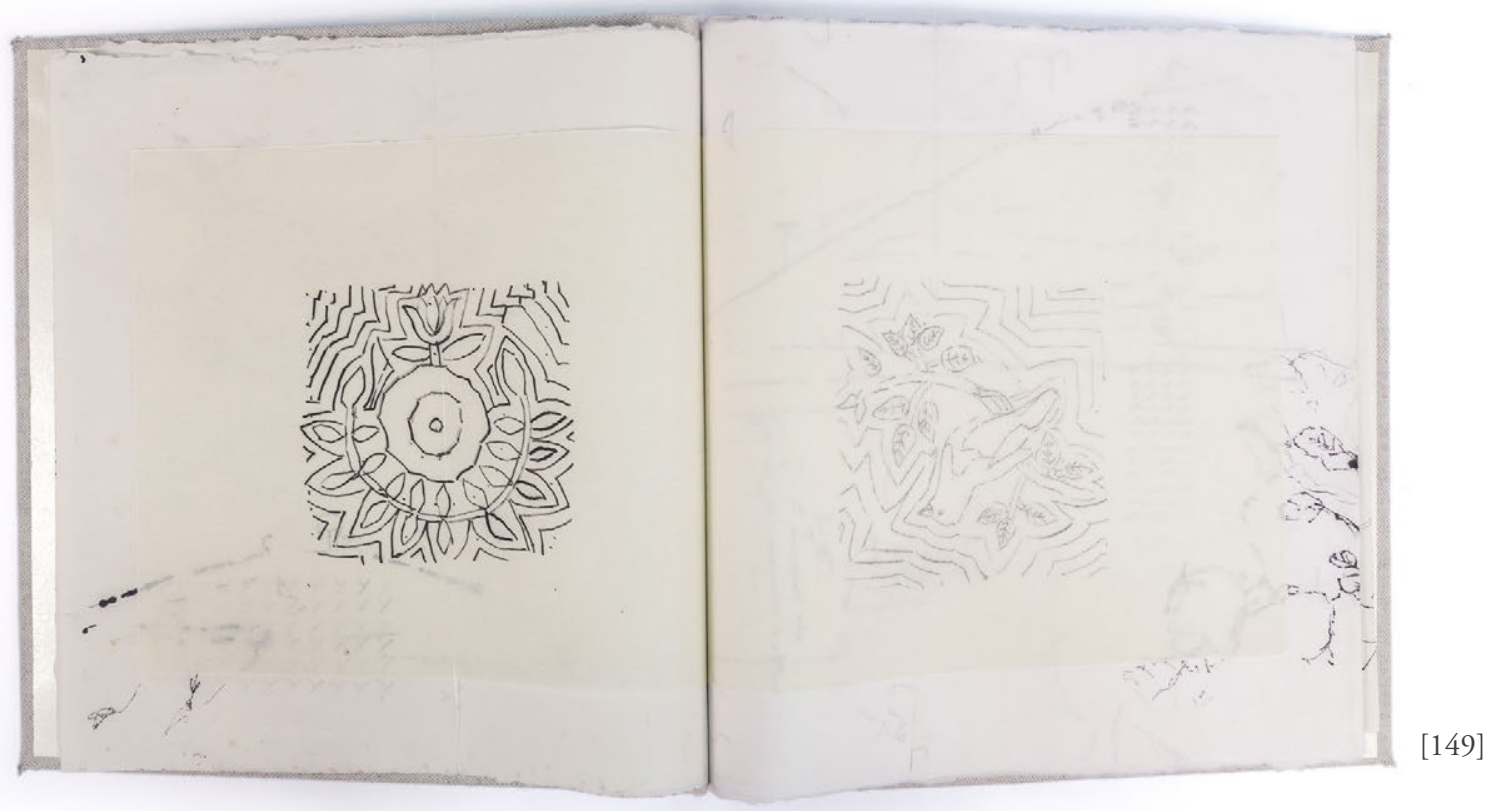



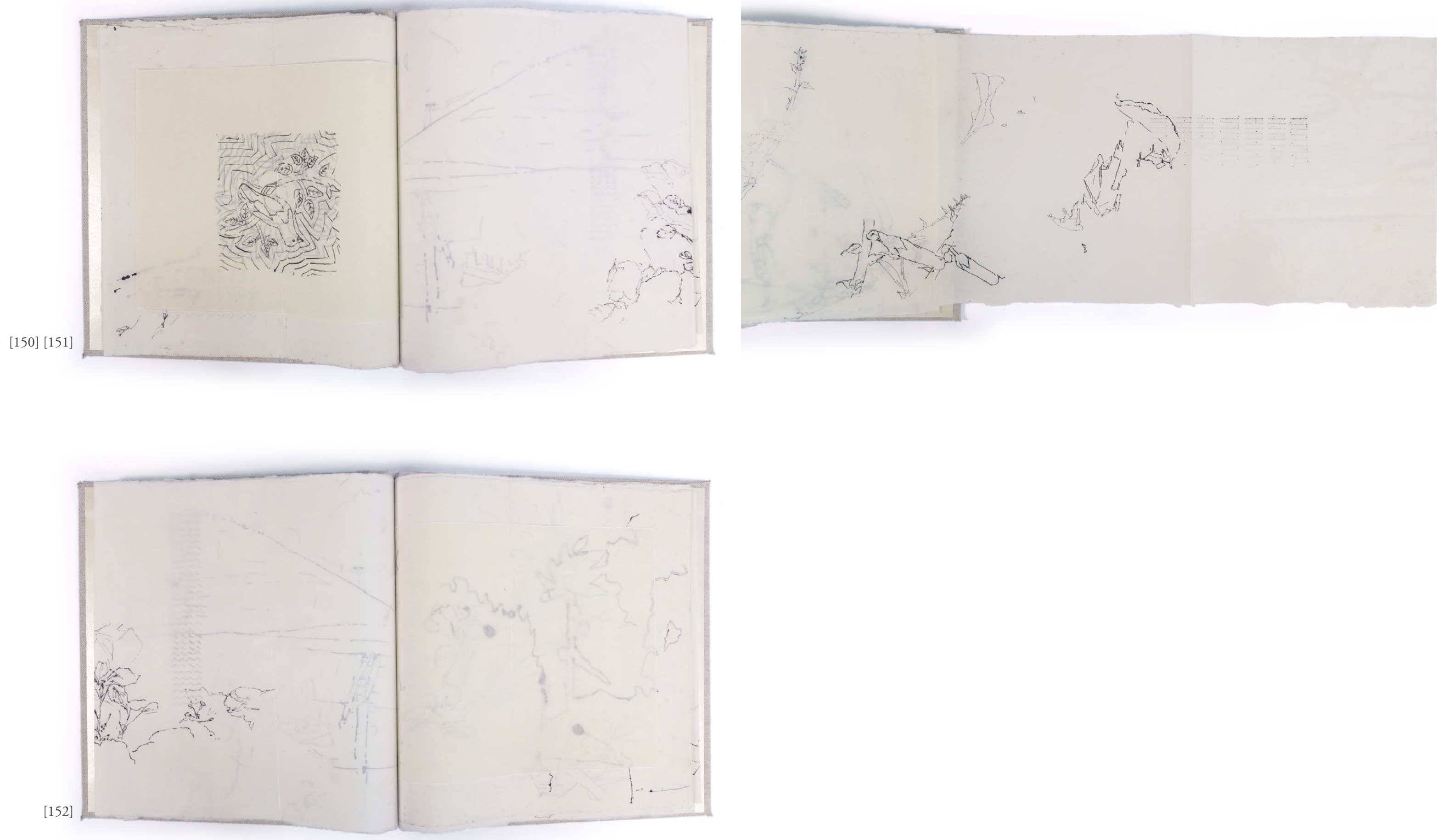

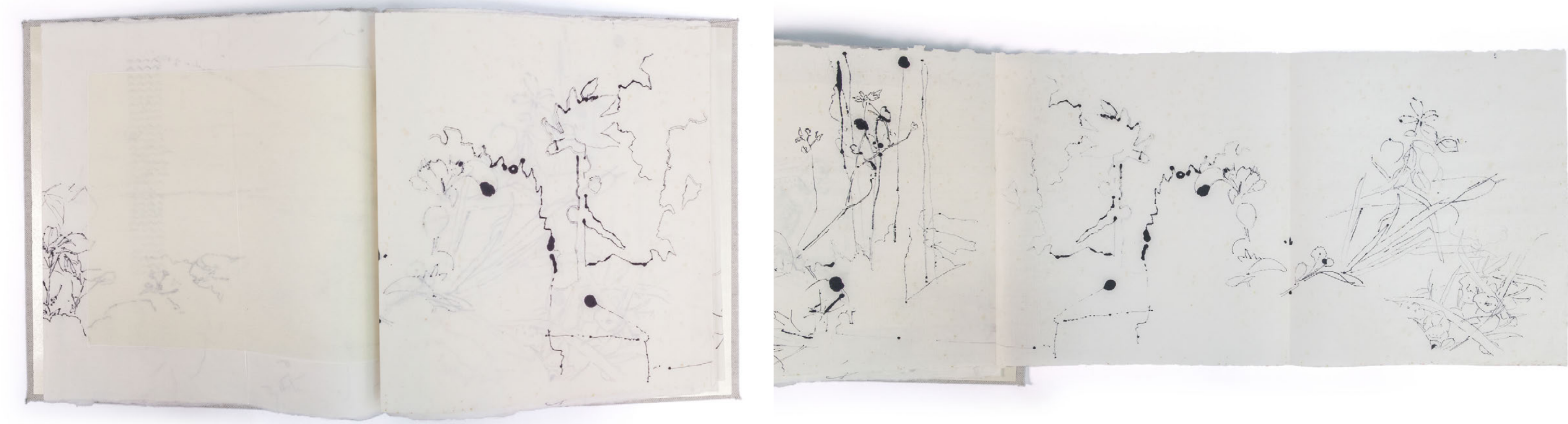


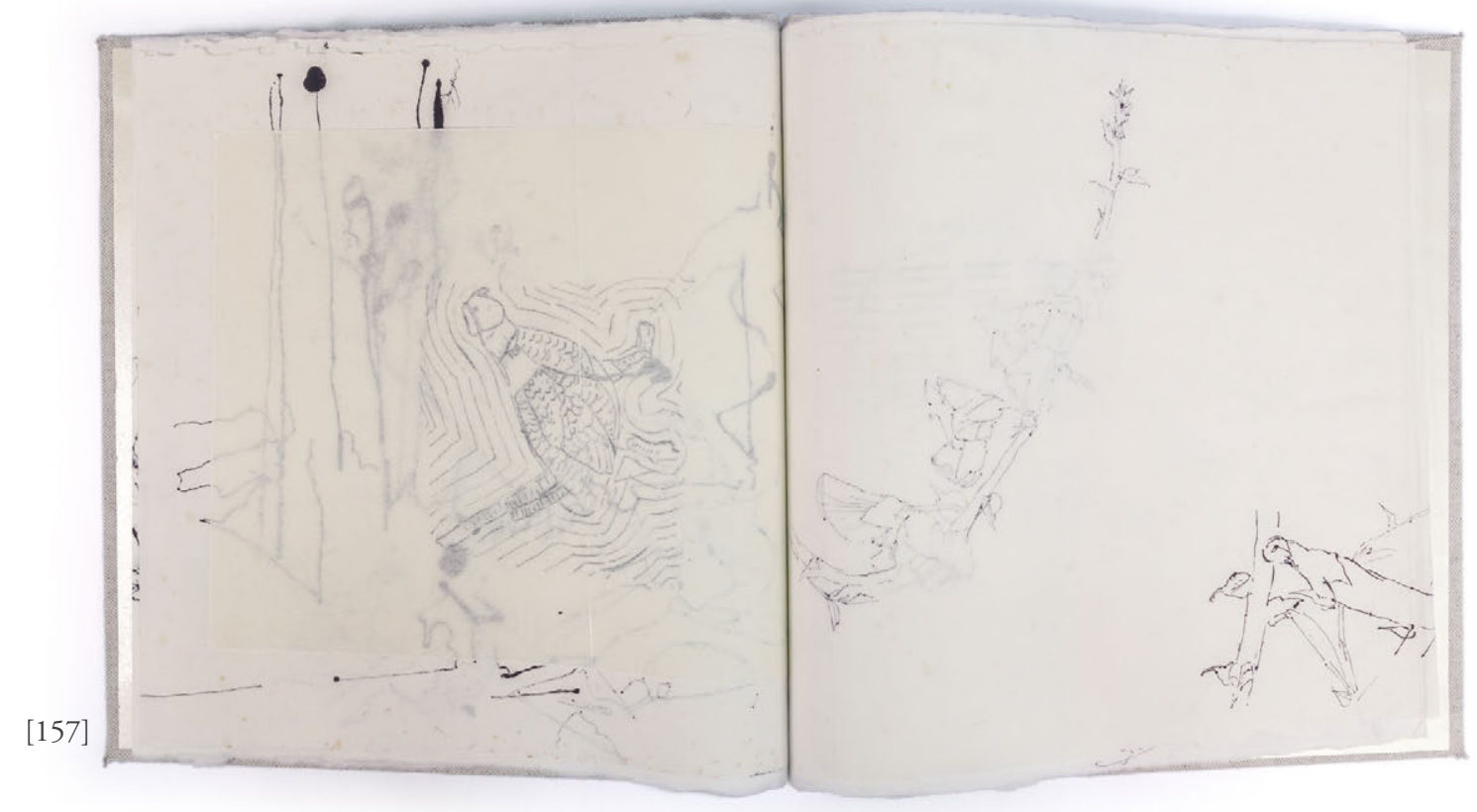

[158] [159]
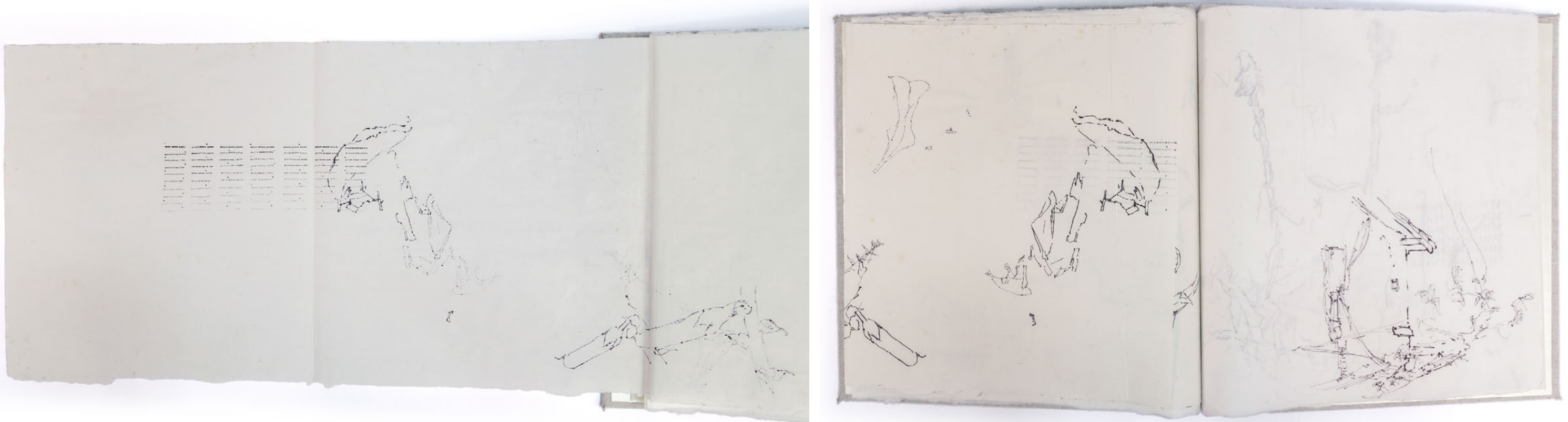


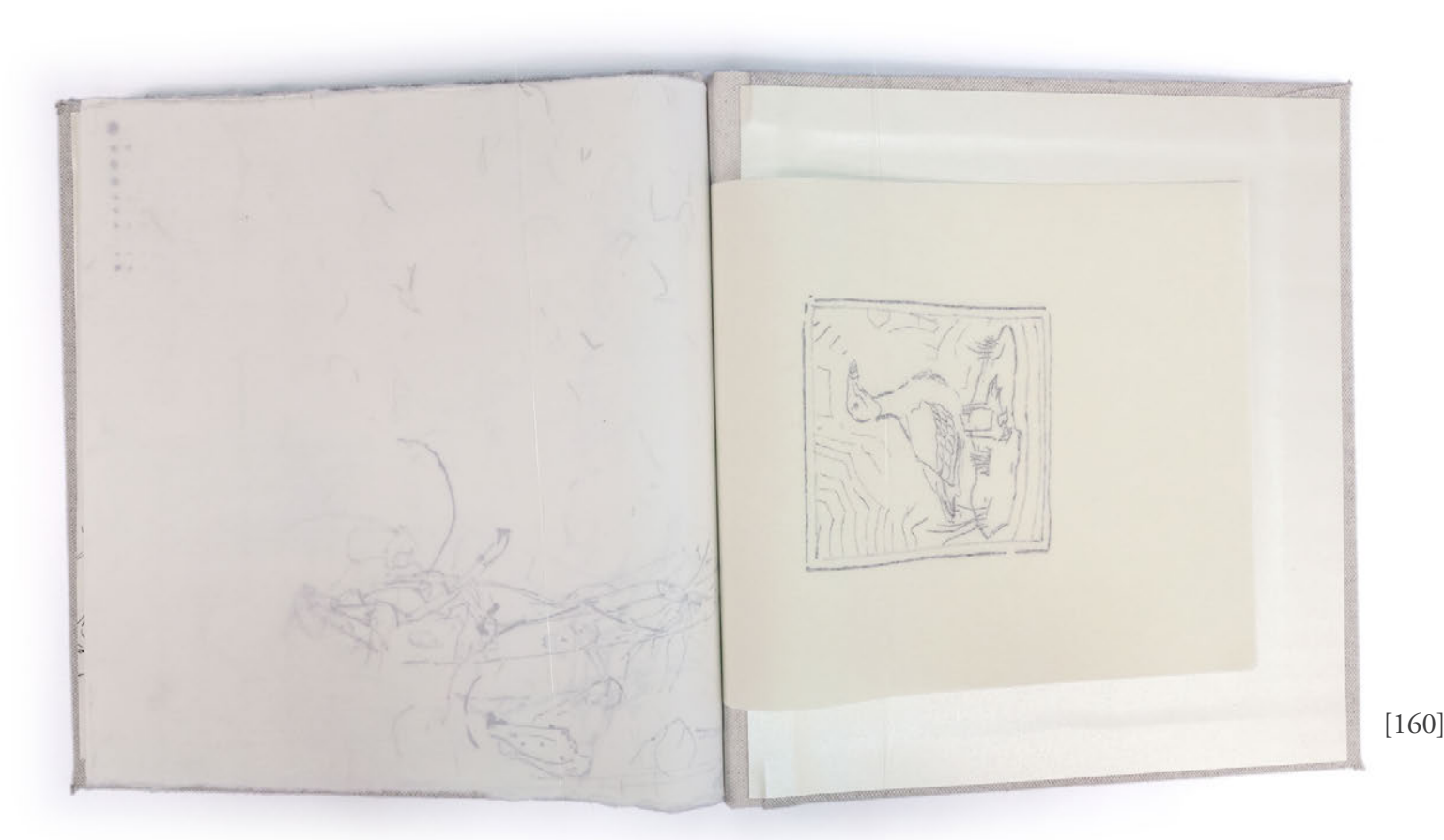

(4) 


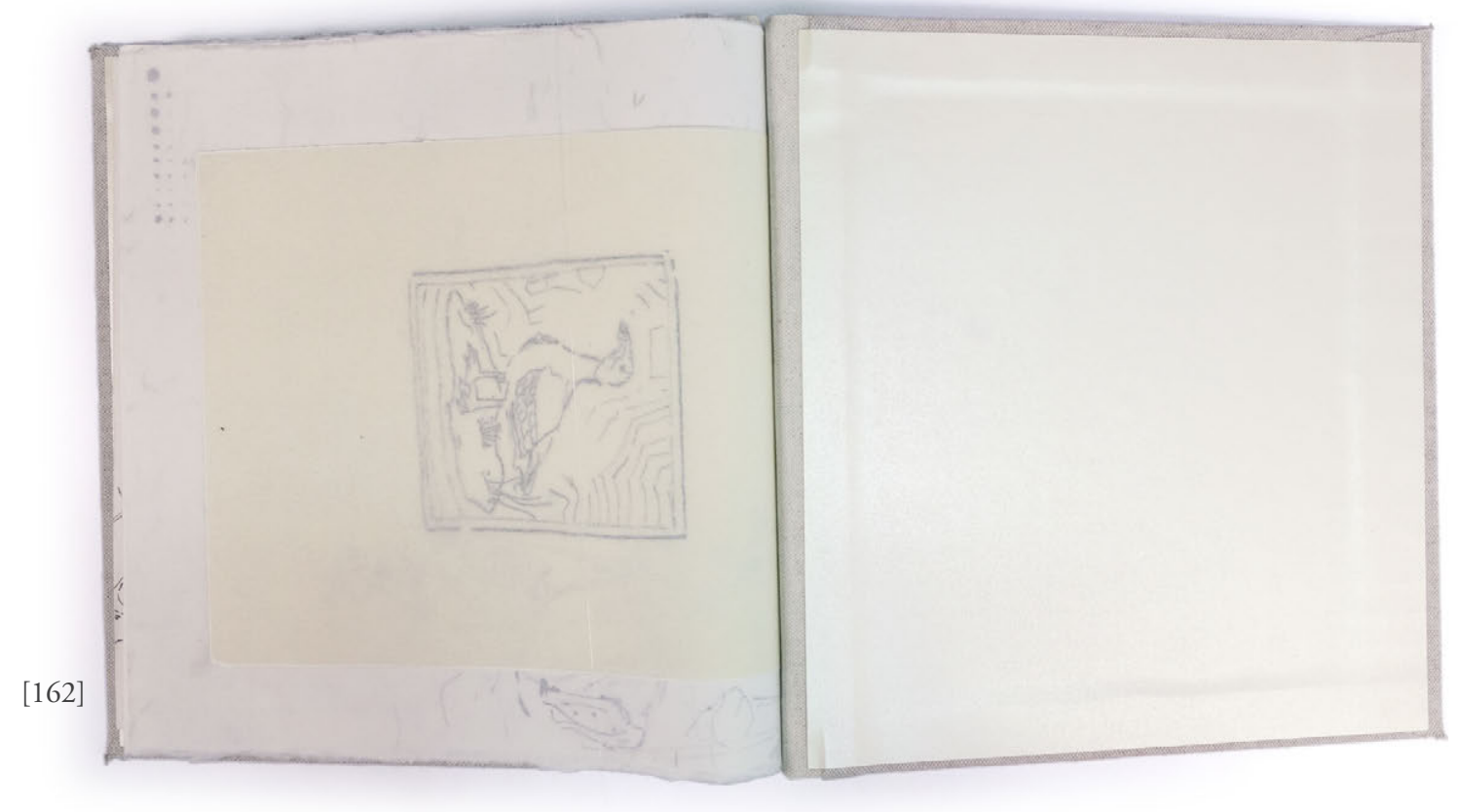

[163]

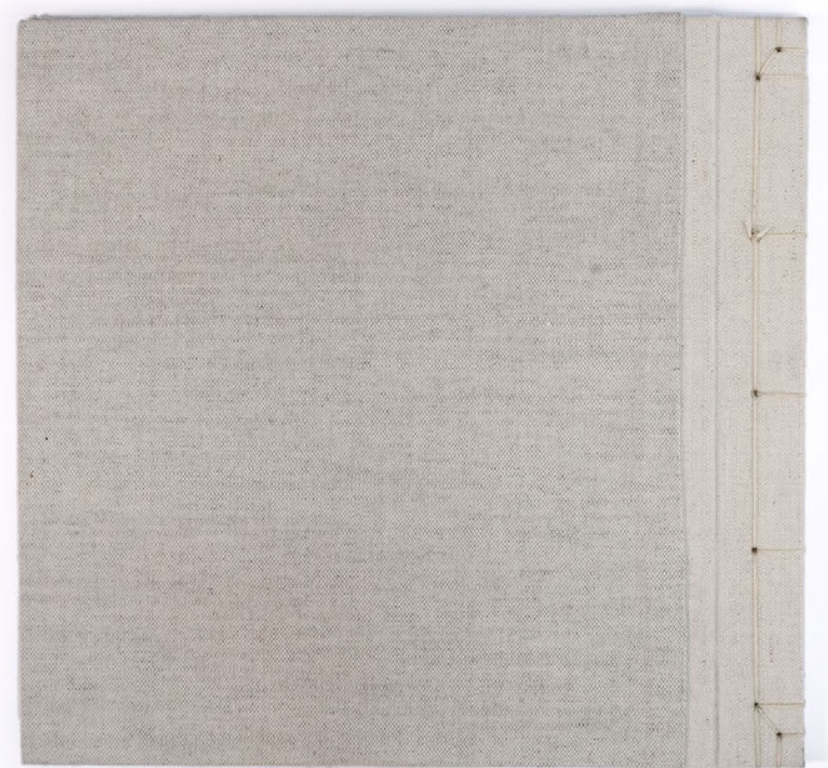



Assim, só depois de haver reconhecido, não sem hesitaçôes, os erros de óptica do princípio, é que se pode chegar ao conhecimento exato de uma criatura, se é que esse conhecimento é possivel. Mas não o é; pois enquanto se retifica a visão que dele temos, ele próprio, que não é um objetivo inerte, muda por sua conta; pensamos apanhá-lo, ele se desloca; e, julgando vê-lo enfim mais claramente, apenas as imagens antigas que haviamos tomado é que conseguimos aclarar, mas essas imagens não $o$ representam mais.

Proust, Marcel. Em Busca do Tempo Perdido: À sombra das raparigas em flor, 530. 





\section{COMENTÁRIOS FINAIS}

O artista segundo Balzac ou segundo Cézanne não se contenta em ser um animal cultivado, fala como o primei-ro homem falou e pinta como se jamais houvessem pintado. Com isso, a expressão não pode ser a tradução de um pensamento já claro, pois os pensamentos claros são os que já foram ditos dentro de nós ou pelos outros. ${ }^{63}$

Por meio da fatura de códices, o projeto investiga uma percepção a partir de processos de desenho e pintura com vistas a elaborar uma poética pessoal. Localizado na área de concentraçáo Design e Arquitetura, na linha de pesquisa Projeto, Processos e Linguagens em Design, o estudo é essencialmente prático, utilizando-se da produção poética como contribuição à reflexão acerca da forma de um objeto banal em nosso cotidiano: o códice.

Para a elaboraçấo dessa poética o conjunto de sete códices desenvolvidos seguiu o tema aglutinado no termo "tempo suspenso". Os processos aqui desenvolvidos foram empregados na realização de códices únicos e irreproduzíveis podendo, a posteriori, serem agrupados em dois conjuntos estéticos: o primeiro do Códice n.1 ao n.3 e o segundo do Códice n.4 ao n.7. A primei-

${ }^{63}$ Meleau-Ponty, O olho e o espirito, 139. 
ra sequência é marcada pela técnica mista - com o uso de pastéis secos ou oleosos, carvão, tinta acrílica, guache, colagens, resina e verniz em papéis de diferentes gramaturas ou sobre tela. Nesse primeiro momento, a principal referência estética foi o desenvolvimento formal do objeto códice ao longo de sua história. "Impregnou-se vida" nos livros por meio de sucessivas sobreposiçóes e raspagens, em referência à linguagem do palimpsesto. Cromaticamente, há a predominância de tons negros, vermelhos e marrons. Já no segundo conjunto é perceptível a entrada de branco nas páginas, principalmente o branco originário do papel deixado à mostra. Em relação aos instrumentos utilizados, a técnica mista deu espaço para um uso reduzido de materiais, em especial restringindo-se às tintas líquidas como nanquim, ecoline e aquarela.

Ao longo dos trabalhos, mudanças graduais foram geradas por conta do desdobramento da compreensão em relação à suspensão do tempo, culminando nos dois últimos códices. Neles, a sobreposiçâao de páginas é parte fundamental nas composiçóes, deixadas em branco na maior parte de suas superfícies. Essa mudança estética deu-se por uma nova abordagem do processo de pintura, no qual buscou-se um estado de espírito específico durante a fatura para, ao final, o objeto estar afetado pelo momento da produção.

Apesar de o segundo grupo possuir uma unidade estética, cada um dos quatro códices possui singularidades em relação ao restante do conjunto. $\mathrm{O}$ Códice n.4, o primeiro do conjunto, rompeu com a linguagem dos livros anteriores e iniciou o processo de produção originário no termo wabi-sabi. É nesse livro que onde encontra-se o maior uso de cores saturadas. Dando prosseguimento a essa abordagem, o Códice n. 5 explora ainda mais a transparência do papel, contudo aqui foram utilizadas fotografias e textos batidos em máquina de escrever, em oposiçáo à predominância do uso de desenho e pintura do restante dos livros. No Códice n.6, a horizontalidade do Códice n.4 é retomada e se impôs ainda mais a presença da transparência a partir do envelopamento de algumas páginas, podendo apenas serem vistas através da parcial translucidez do papel que as envolve. Ademais, nesse livro esboçou-se o método empregado 
no Códice n.7, retomando-se a técnica utilizada no Códice n.4 por meio do desenho de pontos em nanquim, acrescentado de desenhos a partir da observaçâo de vasos de plantas. São justamente esses dois processos que compóem o último códice, acrescido da disposição esparsa pela superfície do papel, do desdobramento de algumas páginas e da prática rigorosa durante o período da residência. $\mathrm{Na}$ transformação entre os códices, evidencia-se o aumento gradual do uso de papéis finos e delicados, tomando uma grande proporção nas frágeis páginas desdobráveis do último livro, no qual a manipulação delas deve ser cuidadosa para que as folhas não rasguem.

Se cada um dos livros do segundo grupo possui características individuais, não seria estranho de se esperar o mesmo em relação ao primeiro conjunto. Formados por tons escuros, a primeira sequência é iniciada pelo Códice n.1, o qual, juntamente com o Códice n.3, possui uma sintaxe visual que se aproxima da história do livro. O primeiro tendo alguns conjuntos de páginas com diferentes estéticas, ora representando palimpsesto, ora lembrando linhas de texto. Unindo esses elementos, uma capa macia pouco dialoga com o interior duro das composiçóes, exceto por sua cor. O Códice n.2 expande o uso de materiais e, justamente por esse motivo, suas páginas são feitas em tela, para absorverem melhor as múltiplas camadas de materiais e as sucessivas açóes de raspagem; o que nem sempre aconteceu. Em alguns momentos, costuras entraram para retomar a unidade das páginas rasgadas. Rico em texturas lisas, enrugadas ou ásperas, os materiais repousados em suas páginas aos poucos cedem ao movimento da leitura, caindo de seu espaço originalmente reservado. Por fim, o Códice n.3 retoma a temática da história do livro, dessa vez na forma do livro de horas. Aqui já há um movimento em direção às mudanças presentes no Códice n.4, pois mesmo possuindo tons semelhantes aos volumes precedentes, sua capa é de um preto único excetuando. Ademais, o conteúdo das páginas é reduzido em relação as formas, cores, texturas e camadas que o compóem.

Uma vez que a espessura das páginas, a proporção dos volumes e os materiais utilizados nas pinturas não são os mesmos, a leitura de cada um dos 
sete códices se dá de maneira singular. Por um lado, o Códice n. 2 possui páginas grandes, pesadas, rugosas que exalam cheiro de verniz, por outro, o Códice n.7 restringe-se ao uso de finos traços em nanquim sob delicadas folhas de papel de arroz, com dobras e sobreposiçóes que exigem calma e tempo durante sua leitura e manuseio. Até mesmo páginas vazias, como o papel manteiga entre as composições do Códice n. 4 ou a dupla camada de papel de restauro entre a capa e o miolo do códice n.6, representam uma mudança no ritmo de leitura.

Como um todo, o conjunto dos livros produzidos apresenta-se como objetos não narrativos. Em suas páginas - ao contrário de livros religiosos, romances ou enciclopédias - não há a presença de uma narrativa desenvolvida linearmente na sucessão das páginas. Em cada um dos volumes há conjuntos de páginas formados por imagens integrando-se em uma unidade estética encerrada entre as capas dos livros. Neles, a leitura também não é linear, por serem compostos por imagens, a leitura é conduzida à uma abordagem holística de cada página dupla na qual o olho percorre toda a superfície do papel ao mesmo tempo em que nota a totalidade da área compositiva. Integralmente, cada livro segue a mesma leitura holística de suas páginas; neles o folhear não necessita de uma ordem preestabelecida, gerando o diálogo com o leitor a partir de sua maneira única de manuseá-lo.

Sendo objetos possuidores de tempo - existente tanto na leitura de cada uma das páginas quanto ao explorar o volume como um todo - o códice é singular em seu uso. $\mathrm{O}$ formato possibilita fisicamente a proximidade com o leitor, permitindo sentir odores e texturas presentes durante a leitura. Com o contato, o ritmo de manuseio se estabelece no diálogo entre as expectativas do leitor em relação aos ritmos internos do livro.

Representado um olhar abrangente da questão levantada em relação à suspensão do tempo por meio da produção de códices únicos - assuntos provenientes, respectivamente, das obras Em busca do tempo perdido (1908-1922) e A última tempestade (1991) - o estudo poderia ser ampliado indefinidamente ao longo de outros experimentos. Como na obra de Proust, o fio desemara- 
nhado a partir de uma sensação pode levar a temáticas inesperadas e retomar assuntos prévios a partir de novas perspectivas. Novos códices poderiam ganhar forma com o aprofundando de elementos já levantados, a partir de novas referências ou combinando assuntos presentes nos sete capítulos. Neles, referências anteriores e sintaxes visuais já desenvolvidas são passíveis de desdobramentos no processo de amadurecimento de uma poética pessoal. 



\section{LISTA DE IMAGENS}

[1] - [6] Quadro do filme A última tempestade (1991) (Ver DVD anexo)

[7] Códice n.1 : capa

[8] Ibidem : p.2 e 3

[9] Ibidem : p.4 e 5

[10] Ibidem : p.6 e 7

[11] Ibidem : p.8 e 9

[12] Ibidem : p.10 e 11

[13] Ibidem : p.12 e 13

[14] Ibidem : p.14 e 15

[15] Ibidem : p.16 e 17

[16] Ibidem : p.18 e 19

[17] Ibidem : p.20 e 21

[18] Ibidem : p.22 e 23

[19] Ibidem : p.24 e 25

[20] Ibidem : p.26 e 27

[21] Ibidem : p.28 e 29

[22] Ibidem : p.30 e 31

[23] Ibidem : p.32 e 33

[24] Ibidem : p.34 e 25

[25] Ibidem : quarta capa 
[26] Códice n.2 : capa

[27] Ibidem : p.2 e 3

[28] Ibidem : p.4 e 5

[29] Ibidem : p.6 e 7

[30] Ibidem : p.8 e 9

[31] Ibidem : p.10 e 11

[32] Ibidem : p.12 e 13

[33] Ibidem : p.14 e 15

[34] Ibidem : p.16 e 17

[35] Ibidem : p.18 e 19

[36] Ibidem : p.20 e 21

[37] Ibidem : p.22 e 23

[38] Ibidem : p.24 e 25

[39] Ibidem : p.26 e 27

[40] Ibidem : quarta capa

[41] The Life and Miracles of Saint Francis of Assisi (Vie et miracles de saint Françoes d'Assise), livro de horas, 143 folhas, $19,5 \times 13,5 \mathrm{~cm}, 1480$.

[42] Gospel of Passau, livro de horas, 44 folhas, 32,5×22,5cm , 1170-1180.

[43] Kacmarcik Book of Hours (Horae Beatae Virginis Mariae), livro de horas, 141 folhas, $16 \times 11 \mathrm{~cm}, 1500$.

[44] Códice n.3 : capa

[45] Ibidem : p.2 e 3

[46] Ibidem : p.4 e 5

[47] Ibidem : p.6 e 7

[48] Ibidem p.8 e 9

[49] Ibidem : p.10 e 11

[50] Ibidem : p.12 e 13

[51] Ibidem : p.14 e 15

[52] Ibidem : p.16 e 17

[53] Ibidem : p.18 e 19 
[54] Ibidem : p.20 e 21

[55] Ibidem : p.22 e 23

[56] Ibidem : p.24 e 25

[57] Ibidem : p.26 e 27

[58] Ibidem : p.28 e 29

[59] Ibidem : quarta capa

[60] - [64] Quadro do filme Primavera, Verão, Outono, Inverno... e Verão (2003) (Ver DVD anexo)

[65] Códice n.4 : capa

[66] Ibidem : p.2 e 3

[67] Ibidem : p.4 e 5

[68] Ibidem : p.6 e 7

[69] Ibidem : p.8 e 9

[70] Ibidem : p.10 e 11

[71] Ibidem : p.12 e 13

[72] Ibidem : p.14 e 15

[73] Ibidem : p.16 e 17

[74] Ibidem : p.18 e 19

[75] Ibidem : p.20 e 21

[76] Ibidem : p.22 e 23

[77] Ibidem : p.24 e 25

[78] Ibidem : p.26 e 27

[79 Ibidem p.28 e 29

[80] Ibidem : p.30 e 31

[81] Ibidem : p.32 e 33

[82] Ibidem : p.34 e 35

[83] Ibidem : p.36 e 37

[84] Ibidem : p.38 e 39

[85] Ibidem : quarta capa

[86] Hasegawa Tōhaku, Shōrin-zu byōbu (Pinheiros), painel esquerdo, tinta 
sobre papel, 1539-1610.

[87] Hasegawa Tōhaku, Shōrin-zu byōbu (Pinheiros), painel direito, tinta sobre papel, 1539-1610.

[88] Ibidem, detalhe.

[89] Códice n.5 : capa

[90] Ibidem : p.2 e 3

[91] Ibidem : p.4 e 5

[92] Ibidem : p.6 e 7

[93] Ibidem : p.8 e 9

[94] Ibidem : p.10 e 11

[95] Ibidem : p.12 e 13

[96] Ibidem: p.14 e 15

[97] Ibidem: p.16 e 17

[98] Ibidem : p.18 e 19

[99] Ibidem : p.20 e 21

[100] Ibidem : p.22 e 23

[101] Ibidem : p.24 e 25

[102] Ibidem : p.26 e 27

[103] Ibidem : p.28 e 29

[104] Ibidem : p.30 e 31

[105] Ibidem: p.32 e 33

[106] Ibidem : p.34 e 35

[107] Ibidem : p.36 e 37

[108] Ibidem : p.38 e 39

[109] Ibidem : p.40 e 41

[110] Ibidem : p.42 e 43

[111] Ibidem : p.44 e 45

[112] Ibidem : p.46 e 47

[113] Ibidem : p.48 e 49

[114] Ibidem : p.50 e 51 
[115] Ibidem : p.52 e 53

[116] Ibidem : p.54 e 55

[117] Ibidem : p.56 e 57

[118] Ibidem : p.58 e 59

[119] Ibidem : quarta capa

[120] Códice n.6 : capa

[121] Ibidem : p.2 e 3

[122] Ibidem : p.4 e 5

[123] Ibidem : p.6 e 7

[124] Ibidem : p.8 e 9

[125] Ibidem : p.10 e 11

[126] Ibidem : p.12 e 13

[127] Ibidem : p.14 e 15

[128] Ibidem : p.16 e 17

[129] Ibidem: p.18 e 19

[130] Ibidem : p.20 e 21

[131] Ibidem : p.22 e 23

[132] Ibidem : quarta capa

[133] Camila Caballero, Sem titulo, 2016.

[134] Isadora Brant, Sem título, 2016.

[135] Isadora Brant, Sem título, 2016.

[136] Silvino Mendonça, Sem título, 2016.

[137] Camila Caballero, Sem título, 2016.

[138] Códice n.7 : capa

[139] Ibidem : p.2 e 3

[140] Ibidem : p.4 e 5

[141] Ibidem : p.6 e 7

[142] Ibidem : p.8 e 9

[143] Ibidem : p.9 (completamente desdobrada)

[144] Ibidem : p.10 (completamente desdobrada) 
[145] Ibidem : p.10 e 11

[146] Ibidem : p.11 (completamente desdobrada)

[147] Ibidem : p.12 (completamente desdobrada)

[148] Ibidem : p.12 e 13 (completamente desdobrada)

[149] Ibidem : p.14 e 15

[150] Ibidem : p.16 e 17

[151] Ibidem : p.17 (completamente desdobrada)

[152] Ibidem : p.18 e 19

[153] Ibidem : p.20 e 21

[154] Ibidem : p.21 (completamente desdobrada)

[155] Ibidem : p.22 (completamente desdobrada)

[156] Ibidem : p.22 e 23

[157] Ibidem : p.24 e 25

[158] Ibidem : p.26 (completamente desdobrada)

[159] Ibidem : p.26 e 27

[160] Ibidem : p.28 e 29

[161] Ibidem : p.30 e 31

[162] Ibidem : p.32 e 33

[163] Ibidem : quarta capa 


\section{REF. BIBLIOGRÁFICAS}

Agostinho, Santo. Confissöes. Traduzido por J. Oliveira Santos e Ambrósio de Pina. São Paulo: Nova Cultural, 1996.

Bandeira, Manuel. “Gesso”. In Estrela da vida inteira, 87-88. Rio de Janeiro, 1990.

Barros, Manoel de. Biblioteca Manoel de Barros : O livro das ignoranças. 18 vols. São Paulo: LeYa, 2013.

Basho, Matsuo. Basho: The complete haiku. Nova York, Estados Unidos da América: Kodansha USA, 2013.

BBC. "In Search of Wabi Sabi with Marcel Theroux". YouTube, janeiro de 2016. https://www.youtube.com/watch?v=Z2P8z7kYJW0.

Borges, Jorge Luis. Borges oral \& Sete noites. São Paulo: Companhia das Letras, 2011.

Cauquelin, Anne. Arte contemporânea: Uma introdução. São Paulo: Martins Editora, 2005. 
Craide, Sabrina. "Olimpíada do Rio terá uso de internet quatro vezes maior que Londres”. Portal de notícias. EBC Agência Brasil, 31 de julho de 2016. http://agenciabrasil.ebc.com.br/rio-2016/noticia/2016-07/olimpiadado-rio-tera-uso-de-internet-quatro-vezes-maior-que-em-londres.

Dogen, Eihei. The Essential Dogen - Writings of the Great Zen Master. Estados Unidos da América: Shambhala Publications, 2013.

Drucker, Johanna. The century of artists' books. Nova York, Estados Unidos da América: Granary Books, 2012.

Greenaway, Peter. A última tempestade. NTSC, colorido, Longa-metragem. Lume filmes, 1991.

Herrigel, Eugen. A arte cavalheiresca do arqueiro zen. Traduzido por J. C. Ismael. São Paulo: Pensamento, 2011.

Herrigel, Gusty L. O zen na arte da cerimônia das flores. São Paulo: Pensamento, 2013.

Hou, Hsiao-Hsien. A viagem do balão vermelho. NTSC, colorido, Longa-metragem. Casablanca, 2009.

Hou, Hsiao-Hsien. Café Lumiére. NTSC, colorido, 2004.

Jardim, João, e Walter Carvalho. A janela da alma. NTSC, colorido, Documentário. Europa filmes, 2001.

Juniper, Andrew. Wabi sabi : the japanese art of impermanence. Singapura: Tuttle Publishing, 2003. 
Ki-duk, Kim. Primavera, Verão, Outono, Inverno... e Verão. NTSC, colorido, Longa-metragem. California Filmes, 2003.

Kiefer, Anselm. Kühlstaub. Hanôver, Alemanha: Edition Heiner Bastian, 2014.

Koren, Leonard. Wabi-sabi for artists, designers, poets \& philosophers. Estados Unidos da América: Imperfect Publishing, 2008.

Lyons, Martyn. Livro : uma história viva. São Paulo: Editora Senac São Paulo, 2011.

Mallarmé, Stéphane. Um lance de dados. Traduzido por Álvaro Faleiros. Cotia, SP: Ateliê Editorial, 2013.

Manguel, Alberto. Uma história da leitura. Traduzido por Pedro Maia Soares. São Paulo: Companhia das Letras, 1997.

Meleau-Ponty, Maurice. O olho e o espirito. São Paulo: Cosac Naify, 2013.

Melot, Michel. Livro,. Cotia, SP: Ateliê Editorial, 2012.

Okakura, Kakuzo. O livro do chá. Traduzido por Leiko Gotoda. São Paulo: Estação Liberdade, 2008.

Okano, Michiko. Ma : entre-espaço da arte e comunicação no Japão. São Paulo: Annablume, Fapesp, Fundação Japão, 2012.

Paiva, Ana Paula Mathias de. A aventura do livro experimental. Belo Horizonte / São Paulo: Autêntica Editora / Edusp, 2010. 
Panofsky, Erwin. Perspective as symbolic form. 6o ed. Estados Unidos da América: Zone Books, 2012.

Proust, Marcel. Em busca do tempo perdido. 7 vols. São Paulo: Globo, 2006.

Proust, Marcel. Em Busca do Tempo Perdido : À sombra das raparigas em flor. Traduzido por Mario Quintana. 3o ed. Vol. 2. 7 vols. São Paulo: Globo, 2006.

Proust, Marcel. Em Busca do Tempo Perdido : No caminho de Swann. Traduzido por Mario Quintana. 3o ed. Vol. 1. 7 vols. São Paulo: Globo, 2006.

Salles, Walter. Abril despedaçado. NTSC, colorido, Longa-metragem. Imagem filmes, 2001.

Shakespeare, William. A tempestade. Traduzido por Rafael Raffaelli. Santa Catarina: Editora UFSC, 2014.

Silveira, Paulo. A página violada : Da ternura à injúria na construção do livro de artista. 2o ed. Porto Alegre: Editora da UFRGS, 2008.

Steiner, George. "O silêncio dos livros". Traduzido por André Telles. Serrote, n.17 (julho de 2014): 77-107.

Sylvester, David. Entrevistas com Francis Bacon. São Paulo: Cosac Naify, 2007.

Tarkovski, Andrei. Esculpir o tempo. Traduzido por Jefferson Luiz Camargo. 30 ed. São Paulo: Martins Martins Fontes, 2010.

Tōhaku, Hasegawa. Shōrin-zu byōbu (Pinheiros). Par de seis pranchas, tinta 
sobre papel, 1539- 1610 .

Valéry, Paul. Degas dança desenho. Traduzido por Christina Murachco e Célia Euvaldo. São Paulo: Cosac Naify, 2012.

Watts, Allan. The way of zen. Nova York, Estados Unidos da América: Vintage books, 1989.

Wenders, Win. Asas do desejo. Colorido e preto \& branco, Longa-metragem. Europa filmes, 1988. 
Dissertação de Mestrado

Título Códice: o tempo em suspensão

Autor Gustavo Grazziano

Revisão Andressa Tiossi Rodrigues

Tipografia Adobe Garamond Pro

Formato A4

Capa Papel holler, papel Hahnemühle e linho

Miolo Pólen 80g, vegetal 70g, sulfite 120g

Encadernação Japonesa

Páginas 228

Universidade de São Paulo

Faculdade de Arquitetura e Urbanismo

Área de concentração Design e Arquitetura

Linha de pesquisa Projeto, processo e linguagens em design

São Paulo, Dezembro de 2016

Versão digital 